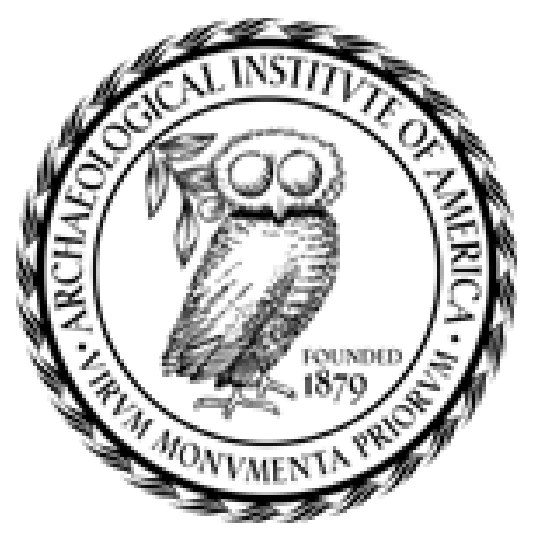

Review of Aegean Prehistory VII: Neopalatial, Final Palatial, and Postpalatial Crete Author(s): Paul Rehak and John G. Younger

Source: American Journal of Archaeology, Vol. 102, No. 1 (Jan., 1998), pp. 91-173

Published by: Archaeological Institute of America

Stable URL: http://www.jstor.org/stable/506138

Accessed: $31 / \overline{12 / 2010 ~ 14: 57}$

Your use of the JSTOR archive indicates your acceptance of JSTOR's Terms and Conditions of Use, available at http://www.jstor.org/page/info/about/policies/terms.jsp. JSTOR's Terms and Conditions of Use provides, in part, that unless you have obtained prior permission, you may not download an entire issue of a journal or multiple copies of articles, and you may use content in the JSTOR archive only for your personal, non-commercial use.

Please contact the publisher regarding any further use of this work. Publisher contact information may be obtained at http://www.jstor.org/action/showPublisher?publisherCode=aia.

Each copy of any part of a JSTOR transmission must contain the same copyright notice that appears on the screen or printed page of such transmission.

JSTOR is a not-for-profit service that helps scholars, researchers, and students discover, use, and build upon a wide range of content in a trusted digital archive. We use information technology and tools to increase productivity and facilitate new forms of scholarship. For more information about JSTOR, please contact support@jstor.org.

Archaeological Institute of America is collaborating with JSTOR to digitize, preserve and extend access to American Journal of Archaeology. 


\title{
Review of Aegean Prehistory VII: Neopalatial, Final Palatial, and Postpalatial Crete
}

\author{
PAUL REHAK AND JOHN G. YOUNGER
}

\section{INTRODUCTION}

In an earlier article in this series, Watrous reviewed the archaeology of Crete from earliest times to the end of the Protopalatial period (MM II). ${ }^{1}$ We continue from where he left off, focusing on Crete from MM III to the end of the Bronze Age (ca. 1700-1100 B.C.). Our main goals are twofold: to summarize critically the present state of the field, concentrating especially on developments of the last 25 years, and to indicate issues, problems, and areas of investigation that need to be addressed in the future.

* We are grateful to Fred Kleiner and Tracey Cullen for the invitation to write this article and for their editorial assistance. We are also indebted to many individuals who gave freely of their knowledge, especially J. Bennet, H. Blitzer, G. Cadogan, E.H. Cline, L.H. Cole, W. Coulson, C. Davaras, L.P. Day, J. Driessen, T. Eliopoulos, G. Gesell, B.P. Hallager, E. Hallager, B. Hayden, L. Hitchcock, S. Hood, A. Kanta, P. Kienzle, O.H. Krzyszkowska, R. Laffineur, M. Lee, A. Lembesi, C. Lilyquist, L. Little, C.F. Macdonald, J.A. MacGillivray, S.W. Manning, J. Moody, P. Muhly, M. Nikolaïdou, B. Olsen, C. Palyvou, I. Pini, G. Rethemiotakis, J. Rutter, L.H. Sackett, I.A. Sakellarakis, E. SapounaSakellaraki, M. Schmid, C. Shelmerdine, J. Soles, M. Tsipopoulou, A.M.P.A. Van de Moortel, L.V. Watrous, J. Weingarten, and J. Zielinski.

The following abbreviations have been used:

Aegean and Orient E.H. Cline and D. Harris-Cline eds., The Aegean and the Orient in the Second Millennium. Proceedings of the 50th Anniversary Symposium, Cincinnati, 18-20 April 1997 (Aegaeum 18, forthcoming).

Archanes I.A. Sakellarakis and E. SapounaSakellaraki, Archanes (Athens 1991).

Atlas J.W. Myers, E.E. Myers, and G. Cadogan eds., The Aerial Atlas of Ancient Crete (Berkeley 1992).

Begg I. Begg, Minoan Storerooms in the Late Bronze Age (Diss. Univ. of Toronto 1975).

Cline E.H. Cline, Sailing the Wine-Dark Sea. International Trade and the Late Bronze Age Aegean (BAR-IS 591, Oxford 1994).

$C M$

S. Marinatos and M. Hirmer, Crete and Mycenae (New York 1960).

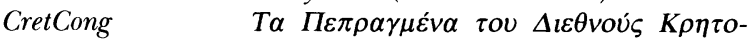

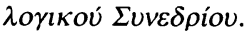

Doumas $\quad$ C. Doumas, The Wall-Paintings of Thera (Athens 1992).
Some changes have occurred since the earlier review and new sources of information have become available: Nestor, a listing of bibliography, has moved from Indiana University to the University of Cincinnati and is published in hard copy and on diskette, and will be responsible for future updates of the International Directory of Aegean Prehistorians (IDAP). The electronic mail discussion network AegeaNet has provided a public forum for a wide range of Aegean topics since 1993. Increasing use is being made of the Internet by archaeologists, and the scholarly acceptance of electronic publication is steadily gain-

Eikon

Ergon

Gesell

Hallager

Immerwahr

Jones

Kanta

Kommos I

Kommos III

Palaces

$P G C$

Politeia

Sanctuaries
R. Laffineur and J.L. Crowley eds. Eıкஸ́v: Aegean Bronze Age Iconography. Shaping a Methodology (Aegaeum 8, Liège 1992).

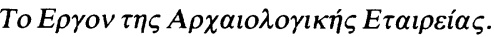

G. Gesell, Town, Palace and House Cult in Minoan Crete (SIMA 67, Göteborg 1985).

E. Hallager, The Minoan Roundel and Other Sealed Documents in the Neopalatial Linear A Administration I-II (Aegaeum 14, Liège 1996).

S. Immerwahr, Aegean Painting in the Bronze Age (London 1991).

R.E. Jones, Greek and Cypriot Pottery (BSA Fitch Laboratory Occasional Paper 1, Lon. don 1986).

A. Kanta, The Late Minoan III Period on Crete: A Survey of Sites, Pottery, and Their Distribution (SIMA 58, Göteborg 1980).

J. Shaw and M. Shaw eds., Kommos I: The Kommos Region and the Houses of the Minoan Town, pt. 1 (Princeton 1995); pt. 2 (Princeton 1996).

L.V. Watrous, Kommos III: The Late Bronze Age Pottery (Princeton 1992).

R. Hägg and N. Marinatos eds., The Function of the Minoan Palaces (Stockholm 1987).

H.-G. Buchholz and V. Karageorghis, Prehistoric Greece and Cyprus (New York 1973).

R. Laffineur and W.D. Niemeier eds., Politeia: Society and State in the Aegean Bronze Age (Aegaeum 12, Liège 1995).

R. Hägg and N. Marinatos eds., Sanctuaries and Cults in the Aegean Bronze Age (Stockholm 1981). 
ing ground. ${ }^{2}$ Other important tools include the continuing publication of seals and sealings in the CMS and its Beihefte, and the compilation of Linear A texts in GORILA.

Since 1987, the Aegaeum series has provided a timely venue for the publication of conferences and monographs on Aegean subjects, and the latest Cretological Congress took place in Herakleion on 10-13 September 1996. Authoritative publication volumes for a number of important sites are appearing or imminent, including Mallia, Mochlos, Chania, Kavousi, Kommos, Kato Syme, and Pseira. The palace at Knossos, which never received a final report in the modern sense, is now being published by areas. ${ }^{3}$ Much important information can be gleaned on in. dividual sites from the photographs and bibliographies in The Aerial Atlas of Ancient Crete (Atlas). An important archaeological resource, the East Cretan Center, endowed by the Institute for Aegean Prehistory, was inaugurated on 19 July 1997, and will be used by excavations all over the east end of the island primarily for study and the storage of finds.

On Crete, the Late Bronze Age is a long and com-

Society

$T A W$ I-III

Techne

Thalassocracy

Zakros

I L.V. Watrous, "Review of Aegean Prehistory III: Crete from Earliest Prehistory through the Protopalatial Period," AJA 98 (1994) 695-753; and relevant papers by J.D. Evans, D. Wilson, J.A. MacGillivray, and G. Cadogan in D. Evely et al. eds., Knossos: A Labyrinth of History (Oxford 1994).

${ }^{2}$ J.F. Cherry and J.L. Davis eds., IDAP' (1995): http: /129.137.36.38/nestor/IDAP/isearch.html. URL for "Argos," a search engine for limited areas in the ancient and medieval worlds: http:/largos.evansville.edu; "Kapatija," a web site for web sites in Aegean and classical archaeology: http://www.duke.edu/web/jyounger/kapat97.html; and "Abzu," a web site for web sites in Near Eastern archaeology: http: //www-oi.uchicago.edu/OI/DEPT/RA/ABZU/ABZU_NEW. HTML. plex period and presents a variety of problems, beginning with terminology and chronology. There is general agreement that the Neopalatial period began after widespread destruction of the Protopalatial centers at the end of MM II and endured through the pottery phases MM III, LM IA, and LM IB. The beginning of this period and the distinction between MM IIIA and B remain hazy, however. ${ }^{4}$ In particular, little agreement exists about the causes of the MM II destructions.

The era following another destruction horizon at the end of the Neopalatial period in LM IB has been called "Postpalatial," based largely on developments observed at Knossos. In recent years, however, it has become clear that palatial administrative activity continued at Knossos until LM IIIA2-B early (discussed below), and certainly into LM IIIB at Chania. It therefore seems misleading to use the term "Postpalatial" for the pottery phases LM II-LM IIIB early, which represent a period of Mycenaean Linear B admin. istration on the island at Knossos and Chania, and perhaps elsewhere; we have abandoned it in favor of the designation "Final Palatial."

'3. Raison, Le palais du second millénaire à Knossos I.1-2: Le quartier nord (Paris 1988); II.1-2: Le front ouest et ses mag. azins (Paris 1993); R. Laffineur, "Habitat égéen et reconstruc. tions: Quelques réflexions méthodologiques à propos du quartier nord-est du palais de Cnossos," in P. Darcque and R. Treuil eds., Lhabitat égéen préhistorique (Paris 1990) 3-19; S. Hood and W. Taylour, The Bronze Age Palace of Knossos. Plan and Sections (London 1981); S. Hood and D. Smyth, Archaeological Survey of the Knossos Area (London 1981).

+ P.P. Betancourt, The History of Minoan Pottery (Prince. ton 1985) 103; P.M. Warren and V. Hankey, The Absolute Chronology of the Aegean Bronze Age (Bristol 1988) 54-60, 135-37; Warren, "A New Minoan Deposit from Knossos c. 1600 B.C., and Its Wider Relations," BSA 86 (1991) 319-40.

5 "Postpalatial" is used by N. Platon, Crete (Cleveland 1966) 206-207. See E. Hallager and B.P. Hallager eds., Late Minoan III Pottery. Chronology and Terminology (Athens 1997); E. Hallager, "The History of the Palace at Knossos in the Late Minoan Period," SMEA 19 (1978) 17-33; E. Hallager, "Final Palatial Crete. An Essay in Minoan Chronology," in Studies in Ancient History and Numismatics Presented to Rudi Thomsen (Aarhus 1988) 11-21; W.D. Niemeier, "Mycenaean Knossos and the Age of Linear B," SMEA 23 (1982) 275-76; Niemeier, "Das mykenische Knossos und das Alter von Linear B," Beiträge zur ägäischen Bronzezeit 11 (Marburg 1982) 29-126. The distinction between LM II and IIIA1 rests pri. marily on the deposits from the Unexplored Mansion (M.R. Popham et al., The Minoan Unexplored Mansion at Knossos [London 1984] section 4) and Chamalevri (M. AndreadakiVlasaki and E. Papadopoulou, "LM IIIA:1 Pottery from Khamalevri, Rethymnon," in Hallager and Hallager [supra] 111-51); and between LM IIIA1 and A2 on deposits from the Unexplored Mansion and Phaistos-Chalara (Kanta 244). 
Here too there is a problem, since it has become increasingly apparent to archaeologists working on Crete that Furumark's phases for Mycenaean pottery, worked out in detail for the Argolid half a century ago, require substantial revision when applied to Crete. ${ }^{6}$ While on the mainland there are accepted diagnostic criteria for distinguishing among the major and minor divisions of LH IIIA-C, there is considerable disagreement among scholars about when these phases begin and end on Crete. Thus, few pottery experts on Crete currently employ the terms IIIB1 and 2, or IIIC1 and 2, preferring instead to refer to IIIB early or late, and IIIC early or late. At the same time, there is no evidence for palatial administration after LM IIIB early, and we therefore restrict the term "Postpalatial" to the late phase of IIIB and all of IIIC. Recently, some scholars have focused their attention on the still problematic transition from the Bronze Age to the Iron Age.

Even the nature of archaeological investigation on Crete is changing. Now that Minoan archaeology is nearing its centenary, its historiography has become a subject in its own right with numerous articles and books. Increasingly within the last two decades, the old arrangement of unilateral, single-nationality excavations is being augmented by surveys and joint projects involving Greeks and the foreign archaeological schools (synergasiai). In addition, much material from earlier excavations is being restudied or reevaluated using new methodologies.

The move toward surveys has become particularly vital, as Crete is subjected to the pressures of its own population and, more importantly, the exigencies of tourism and a tourist-based economy. It is difficult to emphasize sufficiently the seriousness of this problem. It is therefore of crucial importance that intensive recent efforts have been made to survey the existing environment and to safeguard areas of potential

LM IIIB can only be distinguished in early and late phases (Kanta 3), and early IIIB pottery seems almost always to be accompanied by IIIA 2 creating a transitional phase. LM IIIB seems more or less contemporary with LH IIIB, and LM IIIC with LH IIIC. The character of Subminoan is still sketchy, but Cretan Protogeometric is roughly contemporary with Attic Protogeometric.

"A. Furumark, The Mycenaean Pottery: Analysis and Classification (Lund 1941).

${ }^{7}$ O. Rackham and J. Moody, The Making of the Cretan Landscape (Manchester 1997); J. Bennet and M. Galaty, "Ancient Greece: Recent Developments in Aegean Archaeology and Regional Studies," Journal of Archaeological Research 5 (1997) 75-120; D.C. Haggis, "Archaeological Survey at Kavousi, East Crete," Hesperia 65 (1996) 373-432; Haggis, JMA archaeological interest. Surveys have been conducted all over the island (figs. 1-3), including the regions of Sphakia, the Amari valley, the western Mesara plain, the Ayios Vasileios valley, Vrokastro, Gournia, and Kavousi-Thriphti. ${ }^{7}$ The north end of the Isth mus of Ierapetra now represents the most intensively surveyed area of the island.

The expansion of tourist resorts, especially along the north coast, now presents a serious danger to the archaeological heritage of Crete. The area from Herakleion to the palace at Knossos is completely built up along the major road, while to the east the sprawl of Herakleion has enveloped the Minoan port and cemetery areas at Poros, at the mouth of the Kairatos stream. Almost the entire Mallia plain from Chersonissos to the palace site has been subjected to strip building of villas and hotels along the shore. The impending construction of a new hotel at Ayia Varvara just east of Mallia and the construction of a sewer north across the plain from Ayios Nikolaos have prompted a thorough survey of the Mallia region. ${ }^{\circledR}$ In East Crete, the most controversial plan concerns the proposed building of an airfield in the Isthmus of Ierapetra near Vasiliki to service that end of the island; as of summer 1997, the project was still being debated.

Two recent trends are the continuing decentralization of the island's museums and the restudy of monuments and sites, particularly those excavated early in this century and inadequately published according to today's standards. ${ }^{9}$ A new circulatory pattern is being established to accommodate the approximately 2 million annual visitors to Knossos while protecting the exposed architectural remains. Outside Crete, the Evans Archive has been estab. lished at the Ashmolean Museum at Oxford (S. Sherratt, director). Perhaps inevitably and necessarily, reevaluations of work by the early excavators on Crete

6 (1993) 131-74 (Kavousi); B.J. Hayden, J.A. Moody, and O. Rackham, Hesperia 61 (1992) 293-353 (Vrokastro); papers in L. Rocchetti ed., Sybrita. La valle di Amari fra Bronzo e Ferro (Incunabula Graeca 96, Rome 1994), esp. A. Kanta, 67-74; J. Moody et al., 8th CretCong (forthcoming; Agios Vasilios); L. Nixon, 8th CretCong (forthcoming; Sphakia); L.V. Watrous et al., Hesperia 62 (1993) 191-248 (western Mesara).

${ }^{8} A R 36$ (1990) 74; AR 42 (1996) 43; H. van Effenterre, Étude du site (EtCret 13, Paris 1963) 1-53.

9 E.M. Hatzaki, "Construction, Repairs and Reoccupation in the Knossos Town: The Architectural History of the Little Palace," 8th CretCong (forthcoming). P. Kienzle of York University is studying the restorations at Knossos. 


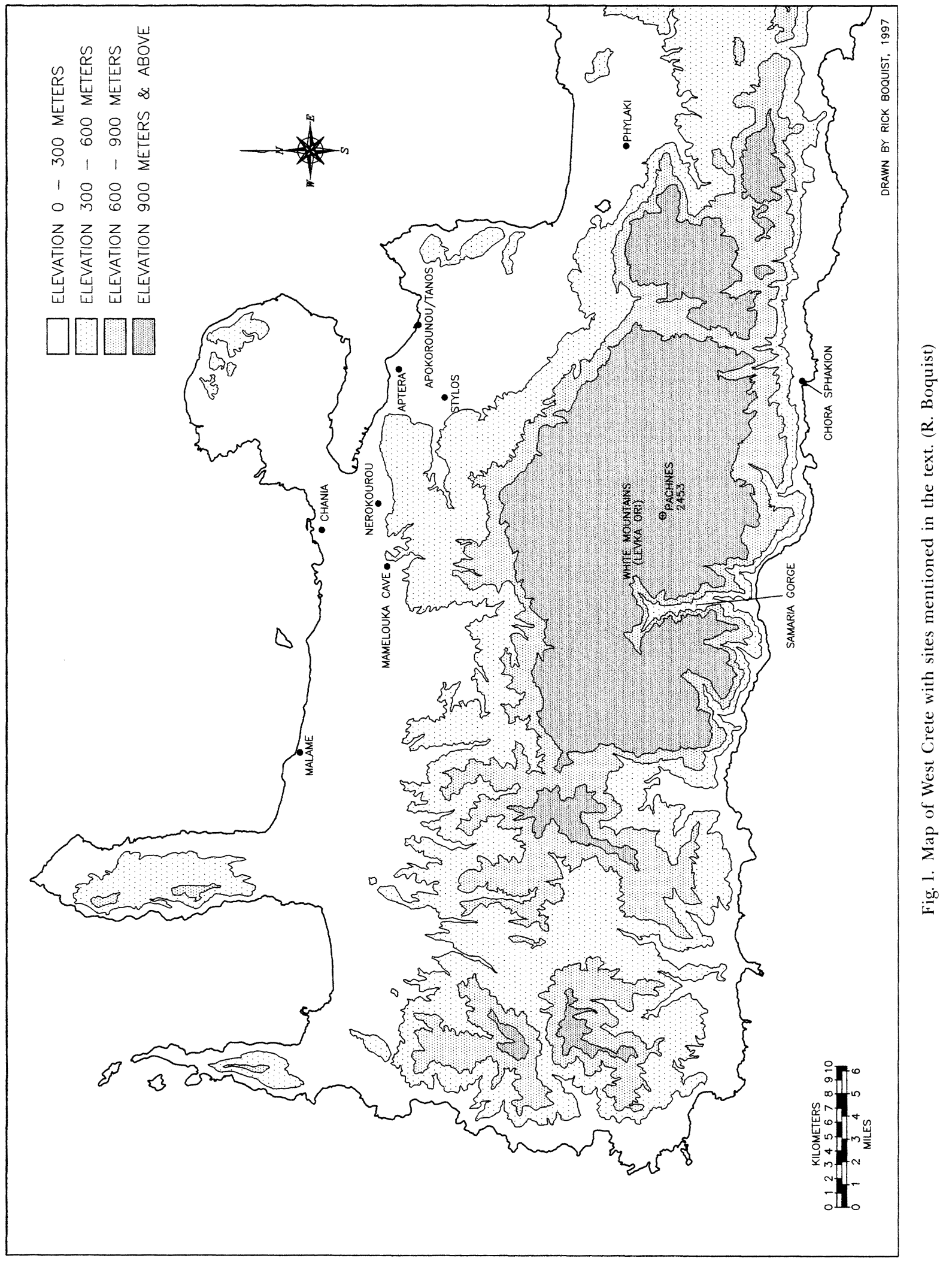




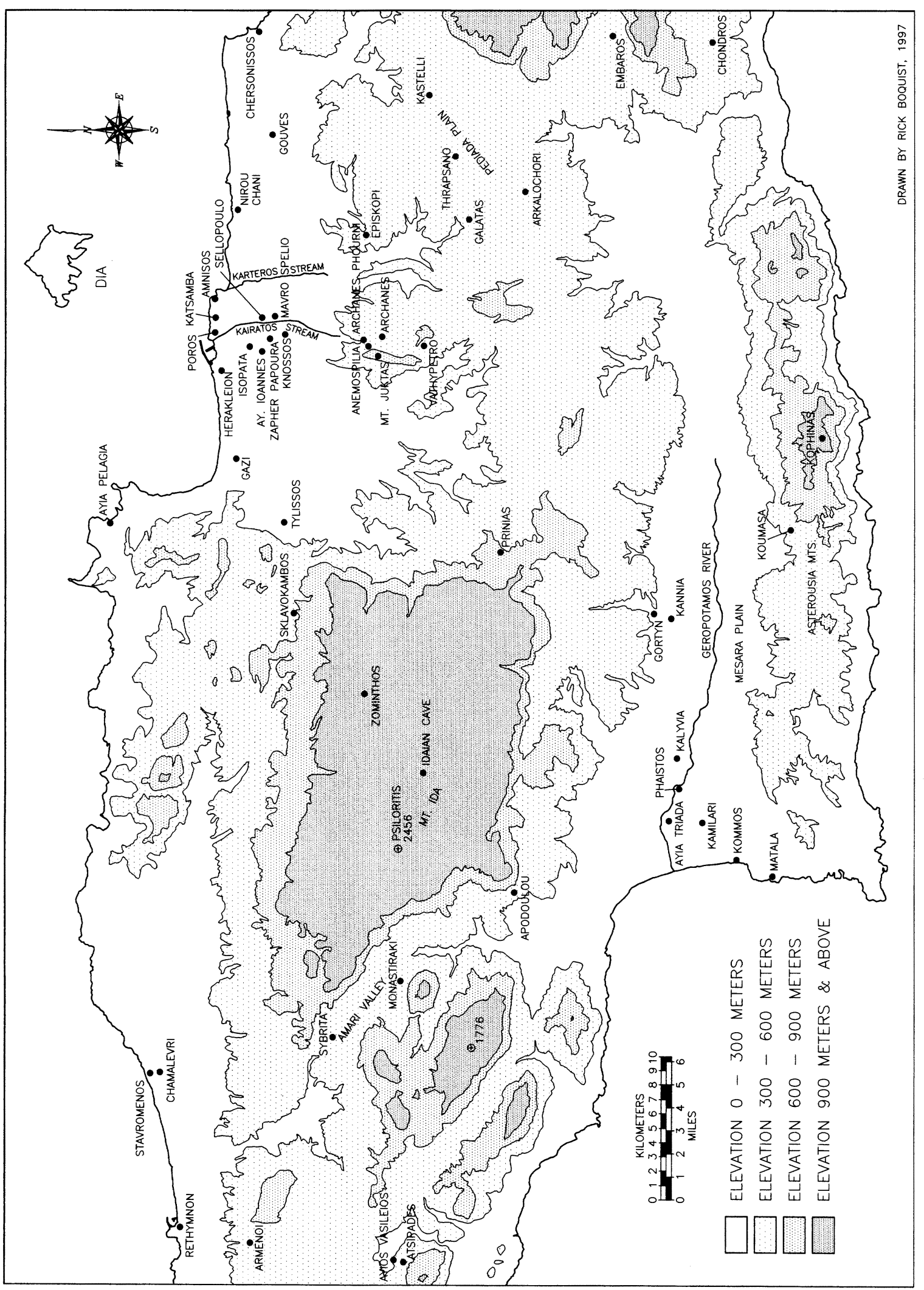




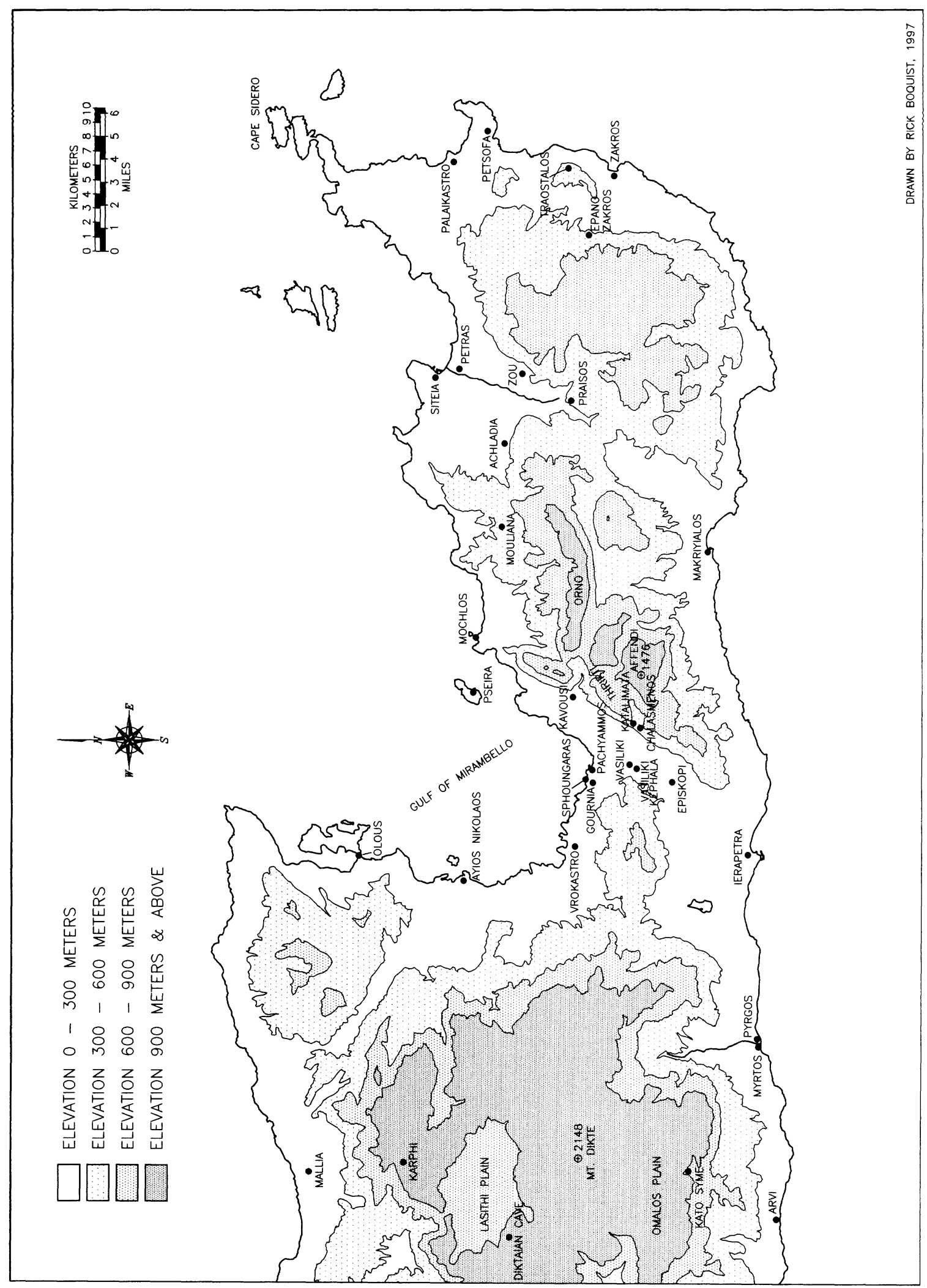

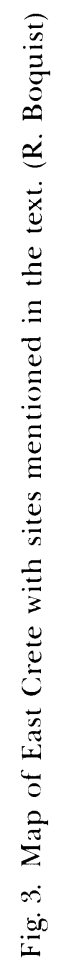


are challenging traditional interpretations of the evidence.

Recent intellectual developments have also contributed to a reevaluation of archaeology on Crete. The New Archaeology of the 1960s and 1970s has led to the investigation of issues in state formation, administration, and economy. More recently, postprocessual archaeology has encouraged an investigation of gender issues, landscape, and ecology. One source of concern is the failure of Aegean archaeologists to engage in constructive dialogue with advocates of more controversial interpretations of Minoan society, particularly the popularized view of ancient Crete as a matriarchy. ${ }^{10}$

\section{SCIENTIFIC STUDIES}

Major advances are taking place in the area of scientific analysis, often fueled by the desire to resolve specific problems (like the origin of the inscribed stirrup jars) or to take advantage of new excavation evidence. Spearheaded by the Fitch Laboratory at the British School and the Wiener Laboratory at the American School of Classical Studies, ceramic and petrographic analyses are beginning to answer ques.

1" E.g., G. Gesell, "The Place of the Goddess in Minoan Society," in Society 93-99; L. Goodison, Death, Women and the Sun (London 1989); L. Meskell, "Goddesses, Gimbutas and 'New Age' Archaeology," Antiquity 69 (1995) 74-86; P. Muhly, "The Great Goddess and the Priest King: Minoan Religion in Flux," Expedition 32:3 (1990) 54-60; L. Talalay, "A Feminist Boomerang: The Great Goddess of Greek Prehistory," Gender and History 6 (1994) 165-83.

"Jones 227, 236, 829 gives an overview and bibliogra. phy; also see J.A. MacGillivray, "Pottery Workshops and the Old Palaces in Crete," in Palaces 273-78. We add the following: late LM IA: Kommos (J.W. Shaw et al., in Techne 323-31), Miletos (W.D. Niemeier, in Techne 347-52); LM II-IIIA: Knossos, east of the Monolithic Pillar Basement (Hood and Taylour [supra n. 3] 282); LM IIIB: Achladia (Kanta 178), Chania (Prakt 1977, 457, fig. 1, pl. 237), Stylos (C. Davaras, ArchEph 1973, 75-80), and Gouves (D. Vallianou, in S. Stiros and R.E. Jones, Archaeoseismology [Exeter 1996] 153-67, esp. 161). Horseshoe-shaped kilns with several parallel flues seem to be early, and $\pi$-shaped kilns are late. The thermoluminescence dates for the MM IB kiln 3 at Phaistos (late 19th century) and for the LM I kiln at Ayia Triada (ca. 1600) seem appropriate; Y. Liritzis and R. Thomas, "Palaeointensity and Thermoluminescence Measurements on Cretan Kilns from 1300-2000 BC, $\mathrm{Na}$ ture 283 (1980) 54-55.

12 J.D. Muhly, "Lead Isotope Analysis and the Archaeologist," JMA 8 (1995) 54-58; Z.A. Stos-Gale, N.H. Gale, and N. Annetts, "Lead Isotope Data from the Isotrace Laboratory, Oxford: Archaeometry Data Base 3, Ores from the Ae- tions about the origin and distribution of clays and vessel types. The recent dramatic rise in the number of potter's kilns discovered ${ }^{11}$ increases the possibility of constructing archaeomagnetic and palaeointensity sequences, helping to refine thermoluminescence dates and to establish the contemporaneity of separated archaeological assemblages. The question of copper and tin sources, which has been be deviling metallurgical studies, has spawned its own techniques, notably lead isotope analysis. ${ }^{12}$ Forensic work on skeletal material, especially from cemeteries at Armenoi (LM IIIA-B), Mochlos (IIIB), and specific buildings at Anemospilia (MM IIIA) and Knossos (LM IB), helps repopulate the archaeological landscape with images of actual Minoans. ${ }^{13}$ An interest in ar. chaeoastronomy is potentially promising, but its value remains to be demonstrated. ${ }^{14}$ A new study of early earthquakes promises a discussion of the problems inherent in identifying seismic damage in antiquity. ${ }^{15}$

For the last decade, Late Bronze Age Aegean chronology has been the subject of serious debate, centering around the dates for the earlier part of the period and particularly the date of the eruption of

gean, Part 1," Archaeometry 38 (1996) 381-90; Z.A. Stos-Gale and C.F. Macdonald, "Sources of Metals and Trade in the Bronze Age Aegean," in N.H. Gale ed., Bronze Age Trade in the Mediterranean (SIMA 90, Jonsered 1991) 249-88; M.S. Tite, "In Defence of Lead Isotope Analysis," Antiquity 70 (1996) 959-62; N.H. Gale, "The Isotopic Composition of Tin in Some Ancient Metals and the Recycling Problem in Metal Provenancing," Archaeometry 39 (1997) 71-82.

${ }^{13}$ J.H. Musgrave et al., "The Priest and Priestess from Archanes-Anemospilia: Reconstructing Minoan Faces," $B S A$ 89 (1994) 89-100. In several studies, P.J.P. McGeorge argues for surprisingly low age-of-death rates (35 in EM, 34 in MM, and 30 for the LM period), a condition that she links to the Minoan economy that prized sheep for their wool and stored commodities (oil, wine, grain) high in carbohydrates;

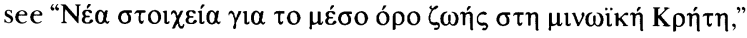

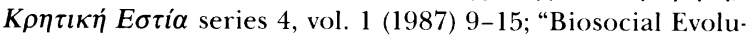

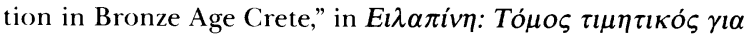

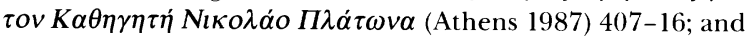
"A Comparative Study of the Mean Life Expectation of the Minoans," 6th CretCong Al (1990) 419-28.

${ }^{14}$ M. Blomberg and H. Göran, "Minos Enneoros: Archaeoastronomical Light on the Priestly Role of the King in Crete," in P. Hellström and B. Alroth eds., Religion and Power in the Ancient Greek World (Uppsala 1996) 27-39; G. Henriksson and M. Blomberg, "Evidence for Minoan Astronomical Observations from the Peak Sanctuaries on Petsofas and Traostalos," OpAth 21 (1996) 94-114.

${ }^{15}$ Stiros and Jones (supra n. 11). 
the Thera volcano. ${ }^{16}$ The subject is too complex to rehearse in its entirety here, but a few of the latest developments should be mentioned. In the field of chronometrics, Kuniholm's Aegean Dendrochronology Project ${ }^{17}$ has established a master ring sequence (CORINA, the Cornell Ring Analysis Program) that supports a date of $1628 / 7$ B.C. for the eruption of Thera.

According to the traditional (low) chronology, based largely on cross-dating with the other cultures of the Mediterranean, the Late Bronze Age begins ca. 1600, with a date for the eruption of the Thera volcano late in the LM IA phase ca. 1500 B.C. The earlier date for the Thera eruption shifts the beginning of the Late Bronze Age even earlier, to ca. 1700 B.C. At present, the high dating for the Thera eruption seems marginally more likely to be correct, and in a recent survey of the material, Manning has sug. gested a "revised high chronology," which is employed here with slight modifications (table 1), in conjunction with the low Egyptian chronology that is now favored by many Egyptologists. ${ }^{18}$

Since LM IA pottery, but no LM IB pottery, was found in eruption deposits on Thera, LM IA must end after 1628/7, let us say ca. 1600 B.C. LM IB now appears to be a longer period than was formerly believed, but its end shortly before the long reign of Tuthmosis III in Egypt is increasingly supported by recent radiocarbon dates. ${ }^{19} \mathrm{LM}$ II, a transitional pottery style, is of short duration. There are good Aegean-Egyptian synchronisms between Tuthmosis

\footnotetext{
${ }^{16}$ For good summaries and bibliography, see J.L. Davis, "Review of Aegean Prehistory I: The Islands of the Aegean," AJA 96 (1992) 735-36; C.W. Shelmerdine, "Review of Aegean Prehistory VI: The Palatial Bronze Age of the Southern and Central Greek Mainland," AJA 101 (1997) 539-41. See also S.W. Manning, "Dating the Aegean Bronze Age: Without, with, and beyond Radiocarbon," in K. Randsborg ed., Absolute Chronology: Archaeological Europe (ActaArch 67, Suppl. 1, Copenhagen 1996) 15-37; K.P. Foster and R.K. Ritner, "Texts, Storms, and the Thera Eruption," JNES 55 (1996) 1-14. On the physical dynamics of the eruption, see various authors in TAW III.2; and Manning, The Absolute Chronology of the Aegean Early Bronze Age (Sheffield 1995) 200-16.

17 Project reports are available on line: http://www.arts. cornell.edu/dendrol. P.I. Kuniholm et al., "Anatolian Tree Rings and the Absolute Chronology of the Eastern Mediterranean, 2200-718 B.C.," and C. Renfrew, "Rings, Tree Rings and the Old World," Nature 381 (1996) 780-83 and 733, respectively; Kuniholm, AJA 99 (1995) 99-102; Shelmerdine (supra n. 16) 539-40, n. 8.

${ }_{18}$ Manning 1995 (supra n. 16) 217-29.

${ }^{19}$ S.W. Manning, "From Process to People: Longue Durée to History," in Aegean and Orient.

${ }^{20}$ C. Renfrew, "Obsidian and Pumice," in Acta of the 1st
}

III and LM IIIA1, and LM IIIA1 pottery was still in use when Amenhotep III came to the throne. The latter's lengthy reign appears to cover much of LM IIIA2. Aegean pottery at Amarna shows that the transition between LH IIIA2 and B1 occurred toward the end of the 14th century B.C. LH IIIB2 is approximately contemporary with some or most of the 19th Dynasty in Egypt, and LH IIIC with the 20th Dynasty.

The Aegean revised high chronology and the tra. ditional low chronology are basically in accord for the latter half of the Late Bronze Age. The primary revision comes at the beginning of the period, with the Neopalatial period contemporary with the late 13th Dynasty in Egypt, the Hyksos period, and the very beginning of the 18th Dynasty, rather than coinciding entirely with the early 18th Dynasty.

The physical effects of the Thera eruption on sur. rounding areas are being debated as well. Seaborne pumice, if occurring in post-destruction contexts, may indicate industrial, ritual, or other uses; The. ran airborne ash and seaborne pumice have been recovered at a number of sites. ${ }^{20}$ Ash has been detected at Gournia, Knossos, Mallia, Nirou Chani, Pyrgos, and Vathypetro in Crete, Phylakopi in Melos, Trianda in Rhodes, Cyprus, Anatolia, the Nile valley, and the Near East (Syria and Israel); larger deposits come from LM IA levels at Palaikastro and Pseira, sealed between LM IA and LM IB floors at Mochlos, in the Dodecanese and Anatolia, and even in the Black Sea region. ${ }^{21}$ Pumice has been found in a LM IA destruction level at Poros (brought by tsunami?)

International Scientific Congress on the Volcano of Thera (Athens 1971) 430-36; J. Driessen and C.F. Macdonald, The Trou bled Island (in preparation), sections 5.2 and 7 give the circumstances and bibliographies, including A.L. Wilson, "The Presence in Crete of Volcanic Ash from Thera," AJA 80 (1976) 419-20.

21 Trianda: thick ash layers have been reported in LM IA levels in two different parts of the town: $A R 38$ (1992) 58-59; $A R 41$ (1995) 59. Dodecanese: ash occurs in LM IA levels at Seraglio on Kos: $A R 41$ (1995) 58; and in LM I levels on Karpathos: E.M. Melas, BICS 29 (1982) 131. Turkey: D.G. Sullivan, AJA 97 (1993) 330 (abstract). Nile valley: D.J. Stanley and H. Sheng, Nature 320 (1986) 733-35. Crete: J.A. MacGillivray et al., BSA 87 (1992) 121-52, esp. 134; $A R$ 41 (1995) 69 (Palaikastro). P.P. Betancourt et al., TAW III.3, 96-99; Betancourt and C. Davaras eds., Pseira I: The Minoan Buildings on the West Side of Area A (Philadelphia 1995) 134-36 (Pseira). J. Soles and Davaras, TAW III.3, 89-95; J. Soles, R. Taylor, and C. Vitaliano, Archaeometry 37 (1995) 385-93 (Mochlos). Black Sea region: F. Gulchard et al., Nature 363 (1993) 610-12. Egypt: Tell el-Dab a: P. Jànosi, Atti del $6^{0}$ Congresso internazionale di egittologia 1 (1992) 345-49, esp. 348; M. Bietak, Avaris: The Capital of the Hyksos (London 1996) 77-78. 
Table 1. Modified High Minoan and Low Egyptian Chronology*

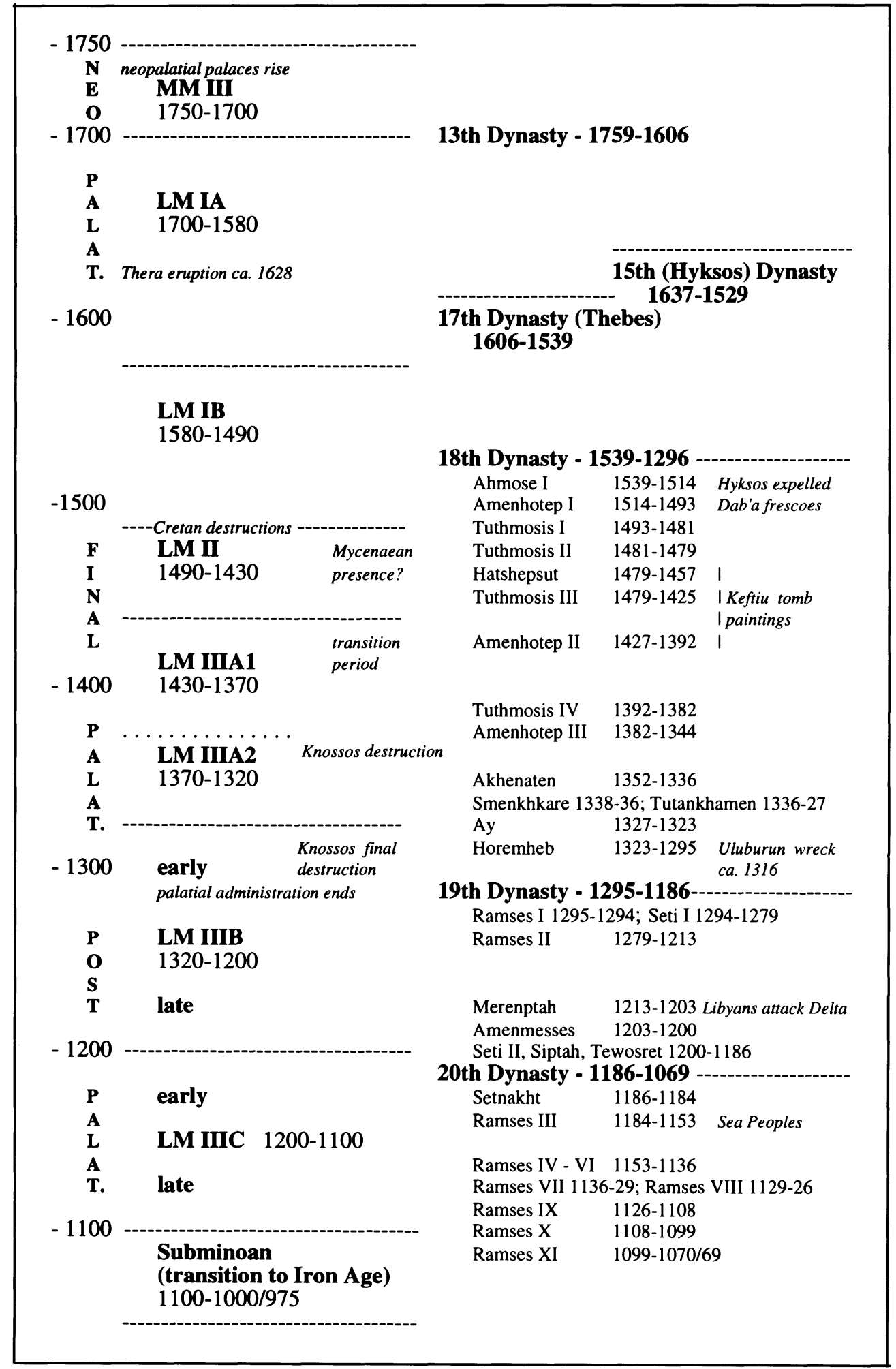

* Revised Aegean high chronology based on S.W. Manning, The Absolute Chronology of the Aegean Early Bronze Age (Sheffield 1995); Egyptian low chronology based on K. Kitchen, "The Basics of Egyptian Chronology in Relation to the Bronze Age Aegean," in P. Aström ed., High, Middle, or Low? Acts of an International Colloquium on Absolute Chronology Held at the University of Gothenburg 20th-22nd August 1987, pt. I (Göteborg 1987) 37-55. 
and in levels postdating the LM IA destruction at Palaikastro; pumice also comes from mature LM IA deposits at the Amnisos villa, Arkalochori, Chania, Mallia palace (IX: 2) and houses (Zb, Zg, E), Nirou Chani, Palaikastro, and Zakros (palace and House F), and from other deposits throughout the Levant and in Egypt. ${ }^{22}$

The effects of the Theran eruption on Crete have been variously interpreted. Because the prevailing winds carried ash east and southeast, some scholars have thought it likely that East Crete may have been hard hit by ash fall, perhaps enough to cause widespread famine. Others, however, more plausibly minimize the effects, suggesting, at worst, a loud bang and a light coating of pumice on the northeastern part of the island that might even have been beneficial to agriculture. ${ }^{23}$

Since the final stages of the Thera eruption must have been visible from the north coast of Crete, the psychological effects of the disaster may have been more devastating than the physical. Economically, the Thera eruption must have forced an immediate reorganization of trade routes, for Thera no longer could have functioned as a critical staging post or emporion for trade. While it is possible that the eruption marks the beginning of a slow shift in the balance of power from the Minoans to the Mycenaeans even before the end of the Neopalatial period, certainly one consequence would have been to shift the direct communication between Crete and the mainland westward through Kythera and West Crete in the latter half of the Neopalatial period. ${ }^{24}$

\section{NEOPALATIAL CRETE (MM III-LM IB)}

\section{Sites and Architecture}

The main foundations of Neopalatial Crete were laid in the Protopalatial period (MM II) with the rise of complex society on Crete, the appearance of peak sanctuaries on low mountains, the continuing use of communal tombs, the emergence of the major

29 AR 38 (1992) 68; AR 41 (1995) 69.

23 Vallianou (supra n. 11); H. Sigurdsson, S. Carey, and J.D. Devine, "Assessment of Mass, Dynamics and Environmental Effects of the Minoan Eruption of the Santorini Volcano," in TAW III.2, 100-12. Some possible effects of the eruption on East Crete are discussed by S. Hood, "The Eruption of Thera and Its Effects in Crete in LM I," 3rd CretCong (1973) 111-18. We are grateful to L.H. Cole for a valuable recent reassessment (personal communication).

${ }^{24}$ E. Schofield, "Plus and Minus Thera: Trade in the Western Aegean in Late Cycladic I-II," TUAS 7 (1982) 9-14.

25 Watrous (supra n. 1) 735-36, 747-50.

${ }^{26} \mathrm{~J}$. Driessen and I. Schoep, "The Architect and the palaces with monumental architecture, sealing administration, a push toward urbanization, and evi. dence for foreign contacts. ${ }^{25}$ The causes of the inter. ruption between the Proto- and Neopalatial periods have not been determined satisfactorily, but major MM II destructions, often by fire, have been noted at Knossos, Phaistos, Mallia (especially Quartiers Mu and $\mathrm{Nu}$ ), Monastiraki, Apodoulou, and Galatas (figs. 1-3). ${ }^{26}$ The trend toward centralization represented by the first palaces may not have been accomplished without resistance. Nevertheless, there seems to have been no significant break in Minoan culture, and the rise of the new palaces appears to signal architectural and administrative consolidation at these centers, probably at different rates at different sites.

At many sites, new building and expansion occurs in MM III/LM IA. The Knossos palace underwent extensive rebuilding or remodeling in the MM IIIB/LM I transition, traces of which are particularly apparent in the west wing. ${ }^{27}$ Recent studies have shown that this expansion is not limited to palatial centers: at Chania, the MM II settlement, remains of which are extensive, was cut back for the construc. tion of MM III/LM I buildings; at Ayia Triada, the villa was built in two stages over an earlier Protopalatial building; at Kommos, a monumental Protopalatial building, AA, was replaced by a monumental Neopalatial building, T. A general trend observable in LM I, toward fewer but larger sites than in MM II, has been noted in the Mesara and Mallia plains. The MM III-LM I foundations or refoundations at many sites are accompanied by extensive terracing, often using megalithic blocks. For instance, the small plateau at Petras was terraced throughout, with a monumental fortification wall with square towers around the base of the hill.

While it is fair to say that, architecturally, Crete reaches its greatest degree of complexity in the Neopalatial period, it is also clear that our general assessment of developments during this period has been simplistic. Neopalatial Crete is not a monolithic

Scribe: Political Implications of Architectural and Administrative Changes on MM II-LM IIIA Crete," in Politeia 649-64.

${ }^{27}$ See Raison 1993 (supra n. 3); W.D. Niemeier, "Knossos in the New Palace Period (MM III-LM I B)," in Evely et al. (supra n. 1) 71-88; and $A R 42$ (1996) 40-41. The Temple Repositories were filled in MM IIIB or LM IA: Hallager I, 54-56; M. Panagiotaki, "The Temple Repositories of Knossos: New Information from the Unpublished Notes of Sir Arthur Evans," BSA 88 (1993) 49-91; I. Pini, "The Hieroglyphic Deposit and the Temple Repositories at Knossos," Aegaeum 5 (1990) 33-60. 
entity that rises uniformly in MM III/LM I and falls at the end of LM IB: rather, the period is punctuated by a series of destructions and rebuildings at almost all sites, and these may have occurred at different times in different places, and perhaps for different reasons. For example, two Neopalatial building phases have been recently distinguished at Pyrgos. Significant LM IA destructions have been documented in recent years at a number of sites, many of them attributed to earthquakes. Palatial Building $\mathrm{T}$ at Kommos passed out of use before the end of IA and a pottery kiln was constructed in its south stoa. The Galatas palace (discussed below) declined and passed out of use in IA. Vathypetro seems to have been abandoned in LM IA after an earthquake. At Petras, an earthquake in LM IA may have occasioned much remodeling; the small palace was altered and continued in use in reduced circumstances in IB. The town at Palaikastro has evidence of severe earthquake damage in LM IA, followed by deliberate demolition of buildings; some areas of the town were unoccupied at the time of the IB destructions. Two wells at Palaikastro with primary deposits datable to IB also contain material probably from the IA destructions. ${ }^{28}$

Some of the changes on Crete may be attributable to the eruption of the Thera volcano late in LM IA, though as noted above, the degree of severity of the attendant factors is debated. In several cases, Theran pumice appears to have been deposited deliberately following the destruction, perhaps in ritual circumstances. At Petras, some of the pumice was deposited in conical cups set on the steps of a monumental stairway, perhaps as votive offerings. ${ }^{29}$ On Pseira, pumice was used as part of the fill under

\footnotetext{
${ }^{28}$ Pyrgos: AR 41 (1995) 68; Kommos, Building T: AR 42 (1996) 42-43; Vathypetro: Atlas 282-85; J. Driessen and I.A. Sakellarakis, in R. Hägg ed., The Function of the "Minoan Villa" (Stockholm 1997) 63-77; Petras: AR 41 (1995) 69-70; Palaikastro: $A R 41$ (1995) 69 . These wells were used into LM IIIA-B as dumps that included a fragment of a relief rhy. ton, sandstone horns of consecration, and large bulls' horns.

29 Personal communication, M. Tsipopoulou.

${ }^{30}$ M.S.F. Hood, "The Destruction of Crete c. 1450 B.C.," BICS 20 (1973) 152.

31 Phaistos: Atlas 232-43; F. Carinci, "The 'III fase protopalaziale' at Phaestos," in R. Laffineur ed., Transition: Le monde égéen du Bronze moyen au Bronze récent (Aegaeum 3, Liège 1989) 73-80; E. Fiandra, "La cretula del vano 10 a Festòs," in Rocchetti (supra n. 7) 15-26; $A R 41$ (1995) 63. Ayia Triada: Atlas 70-77; F. Halbherr, E. Stefani, and L. Banti, "Haghia Triada nel periodo tardo palaziale," ASAtene 39 (1977) 9-342; L.V. Watrous, "Ayia Triada: A New Perspective on the Minoan Villa," AJA 88 (1984) 123-34; and the following articles in Hägg (supra n. 28): V. La Rosa, "La 'Villa Royale'
}

the floor of a LM IB shrine with wall frescoes in relief. Pumice was also deposited under the blocked doorway of a room used as a shrine at Nirou Chani. ${ }^{30}$

In LM IB, it is not entirely clear how extensively the palaces at Knossos and Phaistos were functioning as administrative or habitation centers (they both lack significant deposits of LM IB pottery), but a number of villas show signs of architectural modifications, particularly in increased storage capacity and the restriction of access through areas with pier-anddoor partitions (polythyra). The town at Ayia Triada consists mainly of several houses north and east of the villa apparently in two phases, one dating to the end of MM III, the other destroyed in LM IB, though at least one room contained a destruction fill with much LM IA pottery. ${ }^{31}$ The town at Zakros is spread over two hills, Ayios Antonios to the west and a long ridge north and northeast of the palace. ${ }^{32}$ At least 10 houses on Ayios Antonios and an additional 15 on the northeast ridge have been excavated, revealing a closely packed settlement with large houses, many of which are terraced. At least one house, Hogarth's House A, was destroyed by fire presumably in LM IB, but other houses, like Hogarth's $I / J$, were destroyed by earthquake, while some of the houses on Ayios Antonios seem to have been aban. doned in LM IA.

The situation is similarly uneven in East Crete. The town of Mochlos seems to have been expanding, perhaps under an influx of new settlers. ${ }^{33}$ A LM IB industrial area has been identified on the shore of Crete opposite Mochlos, and a farmhouse at Chalinomouri was established nearby at the same time. The town on Pseira reached its greatest size with ap-

d'Haghia Triada," 79-89; R. Koehl, "The Villas at Ayia Triada and Nirou Chani and the Origin of the Cretan Andreion," 137-49; P. Rehak, "The Role of Religious Painting in the Function of the Minoan Villa: The Case of Ayia Triadha," 163-75. See also $A R 36$ (1990) 70-71; AR 37 (1991) $67-68$. It is possible that the rebuilding of Phaistos did not go smoothly or quickly, and that administration of the western Mesara moved first to Kommos Building T early in LM IA and subsequently, later in LM IA, to Ayia Triada when the villas there were completed (Kommos I.2: 392-96).

32 Zakros: Atlas 292-301; D.G. Hogarth, BSA 7 (19001901) 121-49; Zakros; Ergon 1990, 127-32; AR 36 (1990) 73; AR 37 (1991) 71; AR 38 (1992) 64.

${ }^{33}$ Mochlos: Atlas 186-93; J.S. Soles and C. Davaras, Hesperia 61 (1992) 413-45; Soles and Davaras, Amaltheia 94-97 (1993) 45-65; Soles and Davaras, Hesperia 63 (1994) 391-436; Soles and Davaras, Hesperia 65 (1996) 175-230; Soles, AJA 97 (1993) 302 (abstract); Soles, AJA 98 (1994) 306 (abstract); $A R 36$ (1990) 75; AR 37 (1991) 74-75; AR 38 (1992) 67; AR 41 (1995) 68. 
proximately 60 buildings. ${ }^{34} \mathrm{Within}$ Mochlos, however, House B2 was modified when an extra column base was inserted between two existing columns, perhaps to provide additional support for a sagging roof. At Petras, much of the LM IA settlement was abandoned, and a decline in the quality of LM IB architecture has been observed. Similarly, as noted above, less of the area of the town of Palaikastro was occupied in IB than in IA.

It is also clear that our terminology for describ. ing some of the main architectural features on Crete during the Neopalatial period is no longer adequate. Within the architectural landscape of Crete, there have been three traditional foci of investigation: the palaces, villas, and towns. As noted earlier, however, attempts have been made in recent years in many parts of the island to understand these in terms of their wider territorial settings.

The archaeological preoccupation with the Minoan palaces is evident in the very title of this review, but the meaning of the term is still being debated even after a symposium was dedicated to the subject in 1984..$^{35}$ The term "palace" has traditionally been applied to large court-centered buildings with sophisticated stone architecture that provided for the storage of agricultural produce and its distribution to the surrounding community, housed workshops, and served ritual needs. ${ }^{36}$ In Protopalatial Crete, the palaces generally functioned as the heads of agricultural states, whose territories may have been defined by the natural landscape. ${ }^{37}$ An important role of the palaces was the systematic manufacture of wine, beginning in the Protopalatial

\footnotetext{
34 Pseira: Atlas 262-67; P.P. Betancourt, in Politeia 16366; Betancourt and C. Davaras, Cretan Studies 1 (1988) 35-37; Betancourt and Davaras, Hesperia 57 (1988) 207-25; Betancourt and Davaras (supra n. 21); E.S. Banou, Pottery Groups from the West Side of Area A at Pseira, Crete (Diss. Univ. of Pennsylvania 1992); AR 36 (1990) 76; AR 37 (1991) 75-76; AR 42 (1996) 47.

35 Palaces 235-41 (J. Moody); 255-60 (G. Kopcke); 25153 (S. Alexiou); 261-67 (M. Wiener).

36 Various authors in Palaces. See also K. Branigan, "Social Security and the State in Middle Bronze Age Crete," Aegaeum 2 (1988) 11-16; P. Halstead, "On Redistribution and the Origin of the Minoan-Mycenaean Palatial Econ. omies," in E. French and K. Wardle eds., Problems in Greek Prehistory (Bristol 1988) 519-30; Halstead, "Agriculture in the Bronze Age Aegean: Towards a Model of Palatial Economy," in B. Wells ed., Agriculture in Ancient Greece (Stockholm 1992) 105-17.

37 J.F. Cherry, "The Emergence of the State in the Prehistoric Aegean," PCPS 30 (1984) 18-48; Cherry, "Politics and Palaces. Some Problems in Minoan State Formation," in C. Renfrew and J.F. Cherry eds., Peer Polity Interaction and Socio-Political Change (New York 1986) 19-45; K. Bran-
}

period and peaking in the Neopalatial era, and of oil, beginning in the Neopalatial period and peak. ing in Final Palatial times. ${ }^{38}$ If we are to think away the usual romantic notions about what constitutes a palace, we might do better to substitute the more neutral term "regional center," especially since there is no evidence that the protopalaces or new palaces were the seats of authority for a king or queen. ${ }^{39}$

Four major Neopalatial palaces with Protopalatial predecessors have been excavated on Crete: Knossos, Phaistos, Mallia, and Zakros. These vary in size. Three of the palaces (Knossos, Mallia, and Phaistos) are also characterized by a sizable west court crossed by raised walkways, like modern sidewalks. A fifth palace recently identified at Galatas in the Pediada plain near Kastelli is still being excavated. A sixth (undiscovered) palace may have existed at Chania in the west, and it would be surprising if there is not a seventh still to be discovered in the Rethymnon area, perhaps at Stavromenos-Chamalevri east of the modern town. Monumental Building $\mathrm{T}$ at Kommos consists of four wings arranged around a cen tral court larger than the one at Zakros but smaller than the one at Phaistos; by current definitions, it too could be classed as a palace, perhaps even including its Protopalatial predecessor AA..$^{40} \mathrm{~A}$ sump. tuous building at Tourkogeitonia in Archanes near Knossos has architecture that looks palatial, but it has not been excavated in its entirety, and thus it is not clear whether a central court is present. ${ }^{41}$

Some court-centered buildings are much smaller than the main palaces, an example of which is cur. rently being excavated at Petras in northeastern

igan, "Social Transformation and the Rise of the State in Crete," in Politeia 33-40; M.K. Dabney, "The Later Stages of State Formation in Palatial Crete," in Politeia 43-47; S.W. Manning, Before Daidalos. The Origins of Complex Society and the Genesis of the State on Crete (Diss. Cambridge Univ. 1995).

${ }^{38}$ Y. Hamilakis, "Wine, Oil and the Dialectics of Power in Bronze Age Crete: A Review of the Evidence," OJA 15 (1996) 1-32, esp. 24-25; R. Palmer, Wine in the Mycenaean Palace Economy (Aegaeum 10, Liège 1994); K. Kopaka and L.

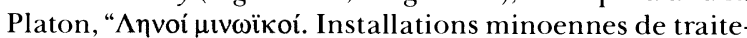
ment des produites liquides," BCH 117 (1993) 35-101.

39 Various papers in P. Rehak ed., The Role of the Ruler in the Prehistoric Aegean (Aegaeum 11, Liège 1995).

${ }^{40}$ See J.S. Soles, "The Gournia Palace," AJA 95 (1991) 72-73 for defining attributes of a palace. Kommos: Atlas 148-53; Kommos I and III; J.W. Shaw, AJA 98 (1994) 305-306 (abstract); Shaw, in Palaces 101-10; J.W. Shaw and M.C. Shaw, Hesperia 62 (1993) 129-90; AR 36 (1990) 71; AR 38 (1992) 60; AR 41 (1995) 61; AR 42 (1996) 43.

${ }^{41}$ Archanes Tourkogeitonia: Atlas 59-62; Archanes $27-$ 48; E. Sapouna-Sakellaraki, BCH 114 (1990) 67-102; I. Sakellarakis and E. Sakellaraki, ArchEph 1991, 169-218; AR 32 (1986) 85-86; AR 36 (1990) 71. 
Crete. $^{42}$ Makriyialos in southeastern Crete is another example that, despite its court, is an architecturally unsophisticated structure probably only a single story in height. ${ }^{43}$ For Gournia, a case has recently been advanced for identifying its main building as a palace in its LM IB phase, although here the court is actually the town's plateia, and the palace encloses it only on the north and west sides, exactly as the villa at Ayia Triada encloses the "cortile superiore." 44 As more and more court-centered buildings are discovered, it is becoming clearer that the presence of a central court alone is not a good indicator of whether a building was a palace. Central courts vary in size from $1,458 \mathrm{~m}^{2}$ in the case of Knossos, the largest, to just $78 \mathrm{~m}^{2}$ in the case of Petras and Palaikastro Building 6 , with a wide range in between. ${ }^{45}$ The court in Building $\mathrm{T}$ at Kommos is shorter than those in the major palaces, but proportionately much wider.

Thus, not only are there more palaces than we had suspected, but some seem to exist in the immediate territory of another (Archanes is only $8 \mathrm{~km}$ from Knossos, and Kommos $7 \mathrm{~km}$ from Phaistos and Ayia Triada). Given the wide range of court-centered buildings in Neopalatial Crete, it would be useful if we knew more about how they functioned in relationship to one another and to their communities. Also, now that we are coming to recognize varieties of court-centered buildings across Crete, it is increasingly clear that two structures stand apart from the rest as "superpalaces" in terms of sheer size and architectural sophistication: Knossos and Phaistos.

With the rise of the new palaces in MM III-LM I certain general changes have been noted. These palaces have less space for storage and redistribution, but more areas for ceremonial activity. Access to the palaces from outside becomes more restricted. In most cases, the dimensions of the central court are reduced. This situation contrasts markedly with the more fluid boundaries of the earlier palaces.

Two new court-centered buildings discovered at Galatas and Petras change our fundamental concept of the Minoan palace. Galatas, excavated by G. Re-

\footnotetext{
42 Petras: M. Tsipopoulou, AAA 20 (1987) 11-30; Tsipo-

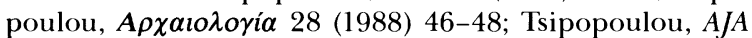
100 (1996) 387 (abstract); AR 32 (1986) 94; AR 35 (1989) 105-106; AR 36 (1990) 76; AR 37 (1991) 76; AR 41 (1995) $69-70$.

${ }^{43}$ Makriyialos: Atlas 172-74; C. Davaras, 5th CretCong (1985) 77-92; Davaras, in Hägg (supra n. 28) 117-35.

${ }^{44}$ Gournia: Atlas 104-11; H.A.B. Hawes et al., Gournia, Vasiliki, and Other Prehistoric Sites on the Isthmus of Hierapetra, Crete (Philadelphia 1908); J.S. Silverman, The Gournia Collection in the University Museum (Diss. Univ. of Pennsylvania
}

themiotakis, ${ }^{46}$ crowns a small plateau overlooking the Pediada, with a steep precipice on the west side and gentler slopes to the north, south, and east (fig. 4). Traces of a substantial surrounding community, including a house with floral fresco decoration, have been detected. From its location, this center must have commanded routes northeast to Kastelli, south to Arkalochori, and northwest to Knossos.

A large paved central court oriented north-south is enclosed by wings; that on the east has been almost completely excavated (including a pillar hall with four piers enclosing a large rectangular hearth, a polythyron, and storerooms with pithoi), the west and south wings are poorly preserved, and the north wing remains to be investigated, except for a small stoa bordering on the court. There appears to be no room for a west court on the plateau. At the north end of the central court is an impressive facade of ashlars resting on a substantial euthynteria, and at least 50 ashlar blocks on the site carry deeply carved mason's marks.

The phasing at Galatas appears substantially different from the other palaces: there is occupation in EM I/II and MM IB-II, but apparently no palace in MM II. The east wing, constructed in MM IIIA, has Knossian affinities in architecture, pottery, and scraps of frescoes with pictorial decoration in miniature; the west wing, overlying substantial architectural remains of the MM II period, dates to MM IIIB/LM IA. The main phase of the complex is MM IIIB-LM IA, but it seems to have been in decline before a destruction in IA, since anly remodeling, including door blockings, was undertaken during this period. Thus far there are no traces of LM IB or LM III material at all, and at the end of the Neopalatial period Galatas may have been supplanted by Kastelli.

Petras, excavated by M. Tsipopoulou, lies a little to the east of Siteia and almost on the coast, occupy. ing a small plateau overlooking the surrounding territory where the Pandelis River empties into the sea. Here, the central court, oriented north-south, is quite small, with the most extensive wing located to the west. The building is actually larger in its LM IA

1978); Soles (supra n. 40).

${ }^{45}$ Sizes of courts in court-centered buildings: Knossos $27 \times 54 \mathrm{~m}\left(1,458 \mathrm{~m}^{2}\right) ;$ Phaistos $22.5 \times 63 \mathrm{~m}\left(1,417.5 \mathrm{~m}^{2}\right) ;$ Mallia $23 \times 48 \mathrm{~m}\left(1,104 \mathrm{~m}^{2}\right)$; Kommos Building T, $38 \times$

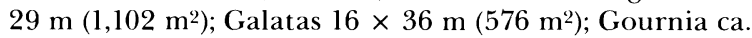
$17.5 \times 25 \mathrm{~m}\left(437.5 \mathrm{~m}^{2}\right)$; Zakros $12 \times 29 \mathrm{~m}\left(348 \mathrm{~m}^{2}\right)$; Palaikastro Building 6, $7.3 \times 10.7 \mathrm{~m}\left(78.1 \mathrm{~m}^{2}\right)$; Petras, first phase, $6 \times 13 \mathrm{~m}\left(78 \mathrm{~m}^{2}\right)$.

${ }^{46} \mathrm{We}$ are grateful to the excavator for guiding us around the site (June 1996) and for supplying the information given here. 


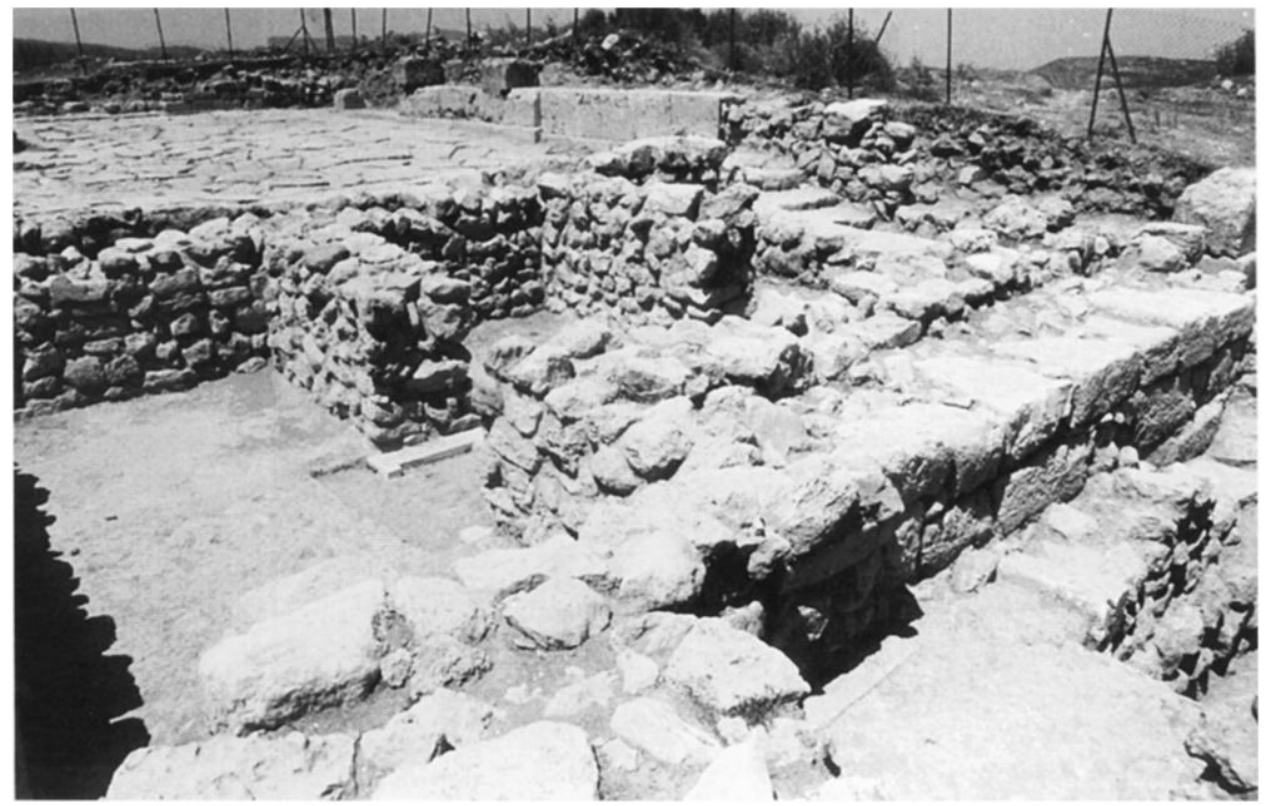

Fig. 4. View of Galatas, northern parts of the east wing and central court. (Courtesy G. Rethemiotakis)

phase; during LM IB, the size of the court was reduced slightly, and a series of storerooms was built at a lower level on the north, using large ashlar blocks with mason's marks, replacing the impressive, wide staircase of the earlier phase. Despite its small size, the commanding location of Petras, its wine press, Hieroglyphic documents, Linear A tablets, and small finds suggest that it was an important administrative center for the region.

In addition to the palaces, smaller freestanding buildings appeared with palatial architectural features but without central courts, which for the sake of convenience we call villas, following Evans. ${ }^{47}$ Whether villas originated in the Protopalatial period is debated, but it is clear that the type proliferated in Neopalatial times, and began to disappear after the LM IB destructions, at the same time as many of the palace centers. This indicates that the villas and palaces formed part of the same basic system. The largest concentration of villas is located around Knossos, and the majority of excavated examples have been found in Central and East Crete, but the villa

\footnotetext{
${ }^{47}$ Various papers in Hägg (supra n. 28); G. Cadogan, "Was There a Minoan Landed Gentry?” BICS 18 (1971) 145-48; J. McEnroe, "A Typology of Minoan Neopalatial Houses," AJA 86 (1982) 3-19; S. Hood, "The 'Country House' and Minoan Society," in Society 129-35; D. Preziosi, Minoan Architectural Design: Formation and Signification (Berlin 1983); G. Walberg, "The Function of the Minoan Villas," Aegean Archaeology 1 (1994) 49-53.

${ }^{48}$ Nerokourou: Atlas 210-12; Scavi a Nerokourou, Kydo-
}

at Nerokourou near Chania (MM III/LM I) attests to the fact that the type was already established in the west from the beginning of the Neopalatial period. ${ }^{48}$

At the "Minoan Villa" conference in 1992, an attempt was made to define a typology for the various types of villas and their functions, following useful guidelines set down by McEnroe for the analysis and classification of Neopalatial houses. Suburban villas cluster around palaces such as Knossos and Mallia, manorial villas served as centers in small towns, and country villas or country houses stood alone in the landscape. Some villas seem to have consisted of one structure linked to another freestanding structure that was subordinate to it: these subsidiary structures have been called villa annexes. ${ }^{49}$

Unfortunately, almost all of these terms are problematic. The term "villa" itself has romantic 19 thcentury overtones of the leisure life, and the adjective "manorial" similarly conjures up associations of a rural gentry. Such concepts may have been completely foreign to Minoan society. Moreover, the

nias I (Rome 1989), rev. by J.A. MacGillivray, AJA 97 (1993) 360-61; S. Chrysoulaki, "Nerokourou Building I and Its Place in Neopalatial Crete," in Hägg (supra n. 28) 27-32; AR 37 (1991) 77.

${ }^{49}$ L.A. Hitchcock and D. Preziosi, "The Knossos Unexplored Mansion and the "Villa-Annex Complex'," in Hägg (supra n. 28) 51-62; cf. Preziosi and Hitchcock, AJA 97 (1993) 349 (abstract). 
buildings usually called Minoan villas vary widely in size, architectural complexity, and sophistication of their contents. The villas around the Knossos palace, for example, are generally far more "palatial" in appearance than the houses around some of the smaller palaces like Mallia or Zakros.

It would be useful if we could distinguish between administrative centers and residences, and between urban and rural expressions, and so discard the term "villa" entirely. A wide range of house types, some of them quite sophisticated, have been identified in the excavated towns of Gournia, Chania, Knossos, Mallia, Mochlos, Palaikastro, Pseira, and Zakros. ${ }^{50}$ At Kastelli, excavation under the modern town has revealed at least one large Neopalatial building of two phases. The structure is monumental and includes a Minoan hall with polythyron, storerooms with pithoi, and small finds suggestive of feasting or libations. ${ }^{51}$

The lack of excavation around some so-called villas makes it unclear whether they stood alone in the countryside, as they appear to us today, or in the midst of urbanized areas. For example, it seems clear that urban areas of greater or lesser extent surrounded the main structures at Ayia Triada, Archanes Tourkogeitonia, Kannia, Tylissos, Nirou Chani, Vathypetro, Pyrgos, and Nerokourou. ${ }^{52}$ More likely to qualify as actual country houses are structures at Zou and Achladia (both inland from Siteia at the east end of Crete), at Epano Zakros, and at Sklavokambos, west of Tylissos and Knossos. ${ }^{53}$ These are located in the agricultural hinterland, some distance away from any major palace center, but even so may have been surrounded by outbuildings and associ-

\footnotetext{
5) Chania: Y. Tzedakis, Prakt 1977, 455-58; Tzedakis and E. Hallager, $A A A 16$ (1983) 3-17; Hallager and Tzedakis, $A A A 17$ (1984) 3-20; Hallager and Tzedakis, AAA 21 (1988) 15-55; AR 36 (1990) 78. Knossos: N. Roberts, BSA 74 (1979) 231-41; E.A. Catling, H.W. Catling, and D. Smyth, BSA 74 (1979) 1-80; Atlas 124-47. Mallia: Atlas 175-85; town expansion and LM IA destruction within the palace, $A R 37$ (1991) 73-74. Palaikastro: Atlas 222-31; R.C. Bosanquet and R.M. Dawkins, The Unpublished Objects from the Palaikastro Excavations, 1902-1906 (BSA Suppl. 1, London 1923); J.A. MacGillivray et al., BSA 95 (1991) 121-47; MacGillivray et al. (supra n. 21); MacGillivray and J. Driessen, in Darcque and Treuil (supra n. 3) 395-412; AR 38 (1992) 67-68; $A R$ 41 (1995) 69.

${ }^{51} A R 36$ (1990) 72; AR 37 (1991) 68; AR 42 (1996) 39; ArchDelt 44 (1989) 428-29.

${ }^{52}$ Kannia: D. Levi, BdA 1959, 237-65; AR 22 (1976) 17, fig. 25. Tylissos: Atlas 272-75; BCH 79 (1955) 299-300, figs. 11-12 (later excavation and restorations). Nirou Chani: S. Xanthoudides, ArchEph 1922, 1-25; PM II.1, 282 fig. 167 (plan), 280-85. Vathypetro: Atlas 282-85; Driessen and
}

ated structures. ${ }^{54}$ Achladia and Zou, for example, consisted of clusters of two or three buildings, and further excavation might show that their settlements were even more extensive. Some important buildings do not fit the designation of either palace or villa. At Zominthos, on the Minoan road up to the Idaian Cave, a massive building has been partly excavated that may have served as a caravanserai, or a hotel for visitors. ${ }^{55}$

Despite their architectural diversity, many town houses and even country houses imitate palatial architectural features or furnishings, a type of emulation that has been termed the "Versailles effect." Such emulation need not imply control of the villas by the palaces; in fact, the evidence for late architectural modifications that include storage areas for agricultural products as at Nirou Chani and for Linear A documents as at Chania House I may sug. gest that during LM IB many of the town houses and country houses were taking over some palatial functions. While this apparent decentralization could be read as a sign that palatial control over outlying centers was weakening, it might signal the opposite: that the palaces were extending their control in to distant regions.

It is difficult to see how some villas could have operated outside the authority of a nearby palace. Tylissos, for instance, overlooks a fertile agricultural area immediately to the west of Knossos and just $13 \mathrm{~km}$ from it. From Tylissos, a direct Minoan route would have led through the gorge on the slopes of the Ida massif up to Sklavokambos and eventually up to Zominthos and the Idaian Cave.

Several suggestions have been made about the

Sakellarakis (supra n. 28). Pyrgos: Atlas 202-209; G. Cadogan, in Sanctuaries 169-71; Cadogan, in Hägg (supra n. 28) 99-103; $A R 41$ (1995) 68.

${ }^{3}$ Zou: Ergon 1956, 110-13; Prakt 1957, 232-40; Zakros 44-45. Achladia: Atlas 48-50; Kanta 178; Ergon 1959, 142-47; L. Platon, in Hägg (supra n. 28) 187-202; M. Tsipopoulou and L. Vagnetti, Achladia. Scavi e ricerche della Missione grecoitaliana in Creta Orientale (1991-1993) (Rome 1995); AR 38 (1992) 64-65. Epano Zakros: Zakros 70-71. Sklavokambos: S. Marinatos, ArchEph 1939-1941, 69-96.

${ }^{54}$ L. Nixon, "Neopalatial Outlying Settlements and the Function of the Minoan Palaces," in Palaces 95-98.

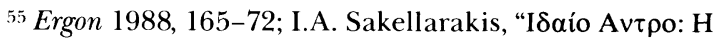

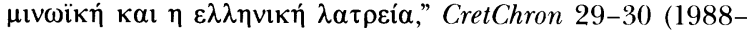
1989) 22-27.

${ }^{56}$ M.H. Wiener, "Crete and the Cyclades in LM I: The Tale of the Conical Cups," in Thalassocracy 17. See also comments by C. Renfrew, "Introduction: Peer Polity Interaction and Socio-Political Change," in Renfrew and Cherry (supra n. 37) 1-18. 
identity of the occupants of the town houses and country houses. To some, they were members of a wealthy upper class who were taxed by the palaces and took part in the palatial redistributive system. ${ }^{57}$ Others have suggested an agricultural base for at least some of these people, as members of a Minoan landed gentry. ${ }^{58} \mathrm{~A}$ third suggestion is that the villas were the seats of members of a priestly class in a theocratic state..$^{59}$ It is quite likely that these regional centers performed several or all of these functions, at least in part.

All of the operating palaces were surrounded by towns, though some towns like Pseira flourished without palaces. The main organizing architectural feature in most towns was the plateia, or town square, which probably served the same centralizing function as the palatial courtyards. Like the palaces, many of the towns seem to have had mixed economies that depended on a combination of agriculture, seafaring, and trade. We do not yet know how to read the architecture of these towns in relation to that of the palatial centers, however, and several types of political structures thus may have coexisted throughout the island.

Most of the excavated towns are concentrated at the east end of the island. ${ }^{60}$ Gournia, at the north end of the Isthmus of Ierapetra, was excavated at the beginning of the 20th century by a pioneering pair of women archaeologists, Harriet Boyd and Edith Hall. The architecture of most of the houses there is fairly humble. Along the north coast of Crete east of Gournia are two more extensively excavated towns, Mochlos and Pseira. Mochlos, originally a small peninsula and now an island, had protected harbors and several impressive houses. A small town flourished on the island of Pseira, which had the only southfacing harbor on the north shore of Crete. ${ }^{61}$ The larger town of Palaikastro at the east end of Crete is currently being excavated; there are many impressive buildings, but as yet no sign of a palace. New settlements are continuously being identified, like the one near the Achladia tholos in East Crete, and a MM III-LM I settlement at Episkopi Pediados. ${ }^{62}$

\footnotetext{
${ }^{57}$ Watrous (supra n. 31).

${ }^{58}$ G. Cadogan, in Hägg (supra n. 28) and Cadogan (supra n. 47).

59 S. Hood, "The Magico-Religious Background of the Minoan 'Villa," in Hägg (supra n. 28) 105-16.

${ }^{60}$ S.D. Indelicato, "Minoan Town Planning-A New Approach," BICS 33 (1986) 138-39; J. Driessen and J.A. MacGillivray, "The Neopalatial Period in East Crete," in Laffineur (supra n. 31) 99-111.

${ }^{61}$ Betancourt (supra n. 34).

${ }^{62}$ AR 36 (1990) 71.
}

These and other examples suggest that Neopalatial Crete may have been far more densely settled than we have suspected.

At the western edge of the Mesara plain stands the major port town of Kommos; it undoubtedly had an important relationship with the nearby palace at Phaistos and villa at Ayia Triada. At Zakros, there is evidence for a substantial Protopalatial and Neopalatial town occupying the hills around the palace. A major town existed at the west end of the island, at Chania, under the modern city.

One of the salient features of Neopalatial Crete, which separates it from the cultures of the Cyclades and the mainland at this time, was the degree to which it was urbanized. No single site has yet been excavated in its entirety, excepting Neopalatial Pseira, and thus we do not know the exact size of any Neopalatial center on Crete itself; nonetheless the size of some Neopalatial urban areas can be estimated. The tight spacing of the houses at Chania, Zakros, and Palaikastro implies that some of the major Cretan centers might have compared favorably in extent with the highly urbanized centers in the eastern Mediterranean.

At Knossos, the eastern limit of occupation is bordered by the lower slopes of the Ailias ridge across the Kairatos stream, while the higher slopes behind the Stratigraphic Museum should curtail the settlement to the west; the Vlychia stream with the Gypsades cemeteries beyond should bound the settlement on the south, while the Zapher Papoura cemetery should be beyond the settlement to the north. With the palace itself at slightly under 1.5 ha, we can estimate the area of urban Knossos around it as a rough rectangle slightly over $0.5 \mathrm{~km}$ wide and slightly under $1 \mathrm{~km}$ long, or about 50 ha in extent, almost exactly the size of Venetian Candia (Herak. leion). If the populations were also roughly equiv. alent, urban Knossos might have had an approximate population of $17,000 .{ }^{63}$ Knossos is unique in Crete not only in its estimated size, but also in the complexity and variety of its architectural forms.

Many of the houses at sites that have been exca-

${ }^{63}$ M.H. Wiener, "The Isles of Crete," TAW III.1, 129-33 gives formulas for size and population. Candia's Venetian population of 17,000 on the eve of the Turkish conquest in 1669 (C. Davaras, Guide to Cretan Antiquities [Park Ridge 1976] 140) yields the reasonable ratio of 340 people per hectare. Hood and Smyth (supra n. 3) 10 estimate a population of 12,000 on 40 densely settled hectares; cf. the similar estimate by T.M. Whitelaw, in Society 339-40, fig. 73 . Cf. estimates for Troy: M. Korfmann, in Politeia 179-80, pl. XXX. 
vated so far are quite large, seldom under $100 \mathrm{~m}^{2}$ on the ground floor, and most are equipped with at least one upper floor as well. Despite the large size of most houses, however, there are few features that allow us to determine the function of various rooms. There are few fixed hearths or kitchen areas, for example, nor has it been possible to identify bedrooms with any degree of certainty. ${ }^{64} \mathrm{On}$ the other hand, baths with cement floors and drains and toilets with drains are common.

Despite the diversity of building types, Minoan architects shared several basic techniques in constructing buildings. Extensive terracing with megalithic limestone boulders was necessary to support many buildings ${ }^{65}$ and the techniques used in terracing were also applied to the creation of small dams on the island of Pseira and probably elsewhere. Some roads were paved, and occasional watchtowers or strong buildings overlooked strategic points. ${ }^{66}$ Architects tended to employ materials found nearby, probably for reasons of economy, and they may have used a standard foot of approximately $33 \mathrm{~cm} .{ }^{67}$

The broad range of Minoan building types is also reflected in the Neopalatial choice of materials. Poros, a soft, creamy yellow limestone, is common on the island. Gypsum, a calcium silicate, is found in several areas, notably near Knossos, Ayia Triada, and Pyrgos; it forms in crystals or sheets, and is translucent. When it is burnt (as it often was in destructions), it turns opaque white. Sandstone (ammouda) is found at Mallia and other sites throughout the island. ${ }^{68}$

Two fancifully named buildings at Knossos were constructed almost entirely of gypsum, the Royal Villa, located north of the palace, and the Temple Tomb to the south. ${ }^{69}$ At Pyrgos, architects found a convenient outcrop of poros a short distance to the

\footnotetext{
${ }^{64} \mathrm{~K}$. Kopaka, "Des pièces de repos dans l'habitat mi noen du II ${ }^{\mathrm{e}}$ millénaire avant J.C.?" in Darcque and Treuil (supra n. 3) 217-30.

6 V. Fotou, "Limplantation des bâtiments en Crète à l'époque néopalatiale: Aménagement du terrain et mode d'occupation du sol," in Darcque and Treuil (supra n. 3) 45-73.

${ }^{66}$ Y. Tzedakis et al., "Les routes minoennes: Rapport préliminaire. Défense de la circulation ou circulation de la défense?" $B C H 113$ (1989) 43-75; Tzedakis, "O $\delta \rho o ́ \mu o \varsigma$

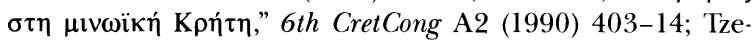
dakis, "Les routes minoennes: Le poste de Hiromandres et le controle des communications," BCH 114 (1990) 43-62;

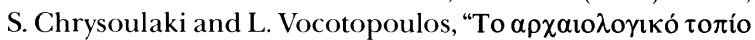

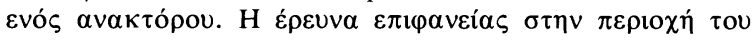

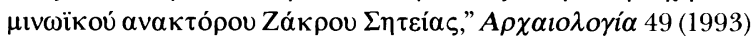
$70-78$.
}

${ }^{67}$ J.W. Graham, "Further Notes on the Minoan Foot," 2nd west of the site and a gypsum source to the east, permitting the use of both materials in the local villa. The sandstone used in the Gournia "palace" was probably quarried at Mochlos to the east. At Pyrgos, Gournia, and other sites near the coast, it was probably easier to ship these materials by sea rather than transport them over land.

A very hard, close-grained blue limestone (sideropetra), found on Cape Sidero, was used in East Cretan architecture, especially for thresholds and column bases. A less fine blue limestone is the basic bedrock of Crete and mainland Greece, and unworked or hammer-dressed boulders of this stone were piled up into irregular courses for terrace walls and the lower walls of major buildings. These walls of megalithic rubble on Crete are basically the same as cyclopean masonry on the Greek mainland. ${ }^{70} \mathrm{On}$ Crete, these same blue limestone blocks were also trimmed for thresholds and column bases, sometimes leaving a rough, unworked part below ground or floor level where it would not be visible. Green, blue, or maroon schist, mottled green serpentine, and pink limestone were also used for pavers for exposed floors and for architectural accents, and all of these materials might be used as regular interior floor paving or for a patchwork effect of irregular pieces, separated by thin bands of plaster painted a contrasting color, often red. Waterproofed floors for bathrooms were paved with tarazza, pebbles set in a plaster mortar.

The Minoan love of architectural polychromy goes back at least into MM II, when a house at Mallia was given a floor of red plaster panels separated by strips of white plaster. ${ }^{71}$ Neopalatial architectural poly. chromy is extravagant. At Pseira, red plaster, sometimes with white borders, was laid in strips, perhaps between wooden frames. Although Building 6 at $\mathrm{Pa}$ -

CretCong (1968) 157-65; M.L. Lang, The Palace of Nestor at Pylos in Western Messenia II: The Frescoes (Princeton 1969) 225.

68 J.W. Shaw, "Minoan Architecture: Materials and Techniques," ASAtene 49 (1971) 1-256. For gypsum, see P.M. Warren, Minoan Stone Vases (Cambridge 1969) 132; N.H. Gale et al., JAS 15 (1988) 57-72. For sandstone, see M.J. Becker, ArchDelt 30 A (1975) 44-85; Becker, JFA 3 (1976) 361-74; J.S. Soles, JFA 10 (1983) 33-46.

69 Royal Villa: $P M$ II, 396-413. At the back of the Minoan hall there is even gypsum veneer over a wall of gypsum blocks. Temple Tomb: PM IV.2, 962-1018; for illustrations, see $C M$ pls. $46-47$. The Temple Tomb is the subject of a forthcoming study by E. Hatzaki.

${ }^{70} \mathrm{~J}$. Zielinski is currently writing a dissertation on the use of cyclopean architecture in the sociopolitical organization of Minoan regional territories.

71 AR 11 (1965) 29, fig. 36. 
laikastro was demolished before the end of the Neopalatial period, surviving traces show that it had floors of maroon schist, green schist, and creamy limestone, blue limestone column bases, and piers of mottled green serpentine. At Archanes, blue limestone column bases are set in a creamy poros threshold. In the South Propylaeum at Knossos, blue-green schist slabs were used as pavers around a cemented pebble floor. ${ }^{72}$ Ornamental stone is also suggested in wall paintings, and patterns imitating veined marble were painted on the walls of a lustral basin at Chania and in the Knossos palace. ${ }^{73}$

Several distinctive masonry styles are known. Neopalatial Crete only rarely had fortification walls, but these were of the same megalithic blocks and boulders used in other buildings. ${ }^{74}$ Dry masonry constitutes entire walls at Zominthos. Megalithic rubble is used to great effect in the west facade of the Zakros palace, where it creates an impression of strength, and, in the town on the hill above, House $\mathrm{G}$ commands attention not only by its location but also for its extensive use of these rough limestone boulders. Ashlar masonry of various types can be found on Crete as early as the Protopalatial period, but its use expands greatly in the Neopalatial era. ${ }^{75}$ Because shaping ashlar was time-consuming, and therefore expensive, it is not uncommon to find ashlar used sparingly, around doorways, and as quoin and anta blocks. Occasionally immense blocks are employed: one at Kommos is more than $3 \mathrm{~m}$ in length. Even in the palaces, ashlar was often used judiciously (the west facade at Mallia, and the west side of the central court at Zakros). Long stretches of ashlar are an impressive sight, though such facades were usually constructed of pseudo-ashlar blocks (rectangular in exterior elevation, roughly trapezoidal on the interior of walls) or orthostats set atop a footing course.

Orthostats are thought to be an architectural feature mainly of the Protopalatial palaces, and they appear only rarely in Neopalatial structures like the

72 PM II.2, 691, fig. 434.

${ }^{73}$ A Knossos fresco depicts a facade resembling Giali obsidian: PM I, 446 fig. 321. Chania: M. Andreadaki-Vlasaki, AAA 21 (1988) 56-76. Knossos: Immerwahr $178 \mathrm{Kn}$ no. 41: from the east wing of the palace, MM III.

${ }^{74}$ Gournia and Petras may be two examples: Driessen and Schoep (supra n. 26). The Zakros wall encircling the south side of the palace is not a fortification wall.

${ }^{75}$ J.W. Shaw, "The Development of Minoan Orthostates," AJA 87 (1983) 213-16.

${ }^{76}$ AR 38 (1992) 62.

77 Shaw (supra n. 68) 88-91; R. Hägg, "On the Reconstruction of the West Facade of the Palace at Knossos," in
Little Palace at Knossos and Building T at Kommos. ${ }^{76}$ The gypsum orthostats resting on a euthyn. teria course visible in the west facade of the Knossos palace are probably remnants of the Protopalatial phase; above them, and on top of a horizontal timber, the walls were constructed of rubble, not the ashlar blocks that appear in many reconstructions. ${ }^{77}$

Enigmatic mason's marks were sometimes incised on ashlars of poros, sandstone, or gypsum, not always on the exposed outer wall surface. ${ }^{78}$ Designs include the double ax, trident, stars, branches, and other motifs, several of which appear as signs in Linear A. As a general rule, deeply cut mason's marks are early (Protopalatial), and shallower ones late (Neopalatial). In the central courts at Phaistos and Galatas, blocks with mason's marks were reused as pavers in the Neopalatial era.

Walls meant to support a second story are thick and have an inner and outer face flanking a rubble core or fill. Half-timber construction, also used for upper courses of walls, employed wooden beams in a variety of ways. Horizontal beams laid on and doweled into ashlar supported wooden frames filled with rubble, and tie beams laid through the rubble wall core were mortised into ashlar faces by swallowtail clamps. Such wooden constructions added elasticity to the wall in case of an earthquake. ${ }^{79}$

The floors in upper story rooms were sometimes paved with thin, square slabs of stone with beveled edges so that they would rest securely on the roofing beams of the rooms below. These slabs are generally of schist, but elegant gypsum pavers were used at Pyrgos. Although Neopalatial red painted floors are common, the MM III Zebra Fresco, painted in black and white stripes in a building outside the Knossos palace, shows that interesting variations did exist. ${ }^{80}$

Stone was often used more sparingly in upper stories, and the Minoans made considerable use of mudbrick for these and other walls and for internal partitions. ${ }^{81}$ In some buildings, closets were constructed of mudbrick, as in the Zakros palace and town, where

\footnotetext{
Palaces 129-33.

${ }^{78}$ Shaw (supra n. 68) 109-11; S. Hood, "Mason's Marks in the Palaces," in Palaces 205-10; we are grateful to S. Hood for supplying us with new information.

${ }^{79} \mathrm{~J}$. Driessen, "Earthquake-Resistant Construction and the Wrath of the 'Earth-Shaker," JSAH 46 (1987) 171-78.

${ }^{80}$ M.A.S. Cameron, "New Restorations of Minoan Frescoes from Knossos," BICS 17 (1970) 163-66, esp. 166; E.S. Hirsch, Painted Decoration on the Floors of Bronze Age Structures on Crete and the Greek Mainland (SIMA 53, Göteborg 1977) 7-22.

${ }^{81}$ Shaw (supra n. 68) 187-205.
} 
mudbrick chests or cists at floor level were used for the storage of goods.

Both ground floor rooms and upper stories could have porches with one or two wooden columns resting on stone bases. Longer stoas used columns and/or piers (sometimes alternating, as at Mallia and Pyrgos), a building form that anticipates the architecture of Archaic and Classical Greece. A pair of impressive stoas, not identical in their arrangement, face each other across the central court of the palatial Building $\mathrm{T}$ at Kommos.

Columns were generally of wood resting on circular stone bases and surmounted by square abaci; most of the latter have not survived and so were probably made of wood as well. ${ }^{82}$ The bases were often of blue limestone, though red was available at Pyr. gos. Breccia, an ornamental stone also used for vases, was employed for column bases in the Knossos palace, along with gypsum bases that were sometimes colossal. Columns represented in frescoes are often painted red, sometimes black, and usually taper significantly from top to bottom. In the Little Palace at Knossos, impressions of fluted columns have been preserved, and a cruciform base at Ayia Triada sug. gests another type of shaped column.

Windows are found throughout Neopalatial buildings, looking out of ground floor rooms to exterior spaces (e.g., Zominthos, Ayia Triada, Mochlos, Nirou Chani, and Zou) and communicating between interior spaces (e.g., Nirou Chani, Ayia Triada, Tylissos House A). Large windows also appear on the upper floors of buildings; offset sections in the walls of some buildings mark the probable location of such windows, as in the west facade of the Knossos palace. ${ }^{83}$

Several architectural components of buildings are characteristic of Neopalatial Crete but are found only rarely in the Cyclades and not at all on the mainland. These include polythyra, which made it possible to subdivide rooms on specific occasions, ${ }^{84}$ light wells to illuminate interior rooms without admitting wind and dust, pillar rooms with one, two, or four massive rectangular piers, sunken pits or lustral basins (discussed below; we do not know their exact function, but they were probably not bathrooms as

\footnotetext{
${ }^{82}$ Shaw (supra n. 68) 111-25; B. Wesenberg, Kapitelle und Basen (Düsseldorf 1971); cf. H. Plommer, "A Carved Block from the Megaron of Mycenae," BSA 60 (1965) 207-11.

${ }^{83}$ J.W. Graham, The Palaces of Crete (Princeton 1972) 162-64; Hägg (supra n. 77).

${ }^{84}$ J.M. Driessen, "The Minoan Hall in Domestic Architecture on Crete: To Be in Vogue in Late Minoan IA?" Acta ArchLov 21 (1982) 27-92; N. Marinatos and R. Hägg, "On the Ceremonial Function of the Minoan Polythyron," OpAth
}

some have suggested), and a large rectangular reception room that we label the Minoan hall. ${ }^{85}$ These modular elements were capable of almost infinite placement: no two Neopalatial buildings have the same plan.

The stone piers for pier-and-door partitions have several different shapes, most commonly resembling the capital Greek letter iota or gamma, and less often the letter tau. These piers are often made of poros or gypsum. Usually only the lowermost pier block was of stone, with mudbrick, timber, or rubble employed above. The general lack of pivot holes in the sills between piers indicates that wooden doors were rare, and curtains may have been used instead.

Pillar rooms (sometimes misleadingly called pillar crypts) are a feature of palaces and villas: these are usually square or rectangular rooms with thick walls that supported a room on the upper story. Inside are square piers, sometimes monolithic, of poros, sandstone, or even gypsum in the case of the Royal Villa at Knossos. Pillar rooms are often considered to have a cultic function, but many have been found to contain large storage pithoi, and they may simply be storage areas. ${ }^{86}$ One pair of basement pillar rooms in Building B-2 at Mochlos has a large window looking onto a street outside the building. ${ }^{87}$

A small stone-lined cist or impluvium is a feature of some houses, mainly at Knossos and in East Crete. In the Royal Villa and Little Palace at Knossos, such sunken cists are a feature of the pillar rooms, perhaps intended for drainage since they may be connected to channels. An example lined with pink limestone to match the rest of the floor appears in the light well of the Pyrgos villa, and another, drained by a covered channel, exists in Building B-2 at Mochlos. On Pseira, an impluvium with a drain has been identified as part of a bathroom, and another was excavated at Palaikastro. One example in the east wing of the palace at Galatas is enigmatic; since it contained burnt material, the excavator has considered it a hearth.

A number of palaces and villas also have low stone benches of similar design. They occur around the walls of the Knossos throne room and its anteroom.

\footnotetext{
16 (1986) 57-73.

${ }^{85}$ J.W. Graham, "The Residential Quarter of the Minoan Palace," AJA 63 (1959) 47-52; Driessen (supra n. 84); L. Hitch cock, "The Minoan Hall System: Writing the Present Out of the Past," in M. Locock ed., Meaningful Architecture (Avebury 1994) 14-43.

${ }^{86}$ Gesell 26-29, for a discussion of the evidence; Begg 29-32.

${ }^{87}$ Soles and Davaras 1994 (supra n. 33) 410.
} 
At both Ayia Triada and Archanes Tourkogeitonia, benches lined three sides of rooms that opened onto courtyards, suggesting that the benches may have served for special gatherings. ${ }^{88}$ In the villas at Pyrgos and Nirou Chani, gypsum benches are situated to provide a view of the interior of the light well.

Despite the richness and variety of Minoan Neopalatial architecture, much of its meaning still eludes us. ${ }^{89}$ Almost certainly, different architectural styles conveyed different messages to the Minoans, with megalithic rubble signaling low-level (local) administration, poros ashlar a higher level (provincial or national), and gypsum (where available) denoting structures that included administrative and religious functions. These visual distinctions among different masonry styles may have been especially important as clues for a largely nonliterate population. The importance of architecture on Neopalatial Crete is underscored by its frequent representation in a variety of media. ${ }^{90}$ The architecture of palace and peak is shown on sealstones and metal rings, as terracotta models, and on stone relief vessels.

\section{Tombs and Burials}

In contrast to the rich and varied architecture of the Neopalatial period, there is a relative dearth of evidence for tombs, though even this situation has changed slightly in recent years. Of the cemeteries close to the Knossos palace, only Mavro Spelio seems to have had extensive Neopalatial use. ${ }^{91}$ On the Kephala ridge north of the Knossos palace, a MM III-LM I tholos tomb was constructed of limestone and gypsum ashlar blocks. ${ }^{92}$ The Temple Tomb south of Knossos on the road to Archanes was used for burials in the Final Palatial period, but its orig-

\footnotetext{
${ }^{88}$ Koehl (supra n. 31) suggests that some of these may have been used by men for drinking ceremonies, anticipating the later Greek andreion.

${ }^{89} \mathrm{~J}$. Driessen, "The Proliferation of Minoan Palatial Architectural Style, I: Crete," ActaArchLov 28-29 (1989-1990) 3-23; J. McEnroe, "The Significance of Local Styles in Minoan Vernacular Architecture," in Darcque and Treuil (supra n. 3) 195-202.

${ }^{90}$ K. Krattenmaker, AJA 95 (1991) 291 (abstract); Krattenmaker, Minoan Architectural Representation (Diss. Bryn Mawr College 1991); Krattenmaker, in Rehak (supra n. 39) 49-59; Krattenmaker, in CMS Beiheft 5 (Berlin 1995) $117-33$.

${ }^{91}$ Hood and Smyth (supra n. 3) 12, 53, no. 251.

92 R.W. Hutchinson, "A Tholos Tomb on the Kephala," BSA 51 (1956) 74-80.

${ }^{93}$ M.R. Popham, The Destruction of the Palace at Knossos. Pottery of the Late Minoan IIIA Period (SIMA 12, Göteborg
}

inal Neopalatial use is unknown, and it may not have been planned originally as a tomb. ${ }^{93}$

At Poros, one of the harbor towns of Knossos, cavetombs of several chambers were hollowed out of the soft kouskouras during MM II-LM IB and served as ossuaries for hundreds of burials, and similar tombs have been excavated at the Minoanized site of Kastri on Kythera. ${ }^{94}$ One tomb at Poros, excavated in 1967 , has already been published, and a second, excavated in 1986-1987, was in use in MM III-LM I, with rich and unusual finds. ${ }^{95} \mathrm{~A}$ few Neopalatial chamber tombs have been identified at Rethymnon, and some MM III pithos burials at Pachyammos and Sphoun. garas. ${ }^{96}$ The large funerary complex at Archanes Phourni was apparently in continuous use from MM II onward, but again there is little evidence for Neopalatial burials.

The relative dearth of identifiable Neopalatial tombs contrasts starkly with the large role of tomb cult in Minoan society in the Pre- and Protopalatial periods and in Final and Postpalatial times. Before the Neopalatial era, built tombs of several forms were used as ossuaries for communal burials, and many tombs were equipped to allow the living to gather, perhaps on ceremonial occasions as well as at the time of burial. From this evidence, Branigan and Soles have hypothesized a widespread veneration of the dead ("cult of the dead"), with the tombs serving as focal points for rituals enacted by the surrounding community. ${ }^{97} \mathrm{~N}$. Marinatos has made this earlier cult a centerpiece for her reconstruction of later $\mathrm{Mi}$ noan religion. ${ }^{98}$

While it is remotely possible that accidents of excavation have caused Neopalatial tombs to be missed, it is reasonable to assume that if tombs had been

1970) 74 .

${ }^{94} A R 10$ (1964) 25

95 A. Lembesi, Prakt 1967, 195-209; P. Metaxa-Muhly,

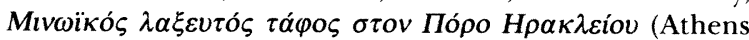
1992). N. Dimopoulou-Rethemiotaki, ArchDelt 42 B2, Chronika (1987) 528-29; AR 33 (1987) 53; AR 36 (1990) 72.

96 M.A. Vlasaki, "O

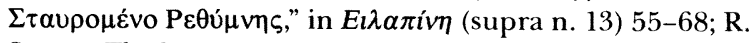
Seager, The Cemetery of Pachyammos, Crete (Philadelphia 1916); E.H. Hall, Excavations in Eastern Crete: Sphoungaras (Phila. delphia 1912) 58-73.

${ }^{97}$ J.S. Soles, The Gournia House Tombs (Diss. Univ. of Pennsylvania 1973); K. Branigan, Dancing with Death (Las Palmas 1992). See also N. Marinatos, Minoan Religion (Columbia 1993) 13-37.

98 Marinatos (supra n. 97) 87-98 connects Neopalatial pillar basements, presence of lamps, baetylic cults, etc., with the earlier cult of the dead. 
constructed in quantity, we would have found more of them. Two recent findings give us pause: the cavetombs at Poros, and the complete lack of Neopalatial tombs on Pseira though the entire island has been investigated. Both suggest that burials were carried out in ways that make detection difficult. One possibility that should be considered is burial at sea. It is possible that, as the Neopalatial palaces central. ized societal functions and ceremonies, family and clan groups may have devised more private ways of burying and commemorating their dead.

\section{Art}

Virtually all the craft forms that flourished in the Neopalatial era originated in Protopalatial times or even earlier. The MM II workshops of Quartier Mu at Mallia, for example, provide evidence for the production of seals, decorated weapons, utilitarian metal vessels, faience, carved ivory, stone vases, and terracotta relief. ${ }^{99}$

The hallmarks of Minoan Neopalatial art include its tendency toward miniature scale, use of precious materials, often imported, in combination for color contrast and enhanced value, and its sharing of artistic techniques and iconographic motifs among several media. ${ }^{100}$ Most Neopalatial workshops and their products are connected with the palaces and major villas; art can therefore be considered a form of elite expression and self-definition.

Stoneworking was the Minoan craft at which artisans excelled from early times through the Neopalatial period. The commonest types of stone in all periods were the local soft stones (2.5-4 on the Mohs scale), steatite, serpentine, sandstone, and limestone. ${ }^{101}$ In the Neopalatial period, harder stones (up to $7+$ on the Mohs scale) could be worked: the conglomerate breccia and the porphyritic lapis

${ }^{99}$ B. Detournay, J.C. Poursat, and F. Vandenabeele, Les fouilles exécutées à Mallia: Le Quartier Mu (Paris 1980).

${ }^{10 \%}$ K. Branigan, "Craft Specialization in Minoan Crete," in Society 23-33; G. Clarke, Symbols of Excellence (Cambridge 1986); M. Helms, Ulysses's Sail (Princeton 1988); Helms, Craft and the Kingly Ideal (Austin 1993); F. Matz, "The Maturity of Minoan Civilization," CAH ${ }^{2}$ II.1 (1973) 156-59 argues that Minoan art developed first on a small scale, largely due to developments on seals.

${ }^{101}$ Serpentine is used here as a general term for a soft (Mohs 2-3), dull, dark (gray, gray-green) stone that is common in Crete; steatite is slightly softer (a variety of talc), greasy, shiny, and bright, with a wider color range from white to black; sandstone was used primarily in architecture: Shaw (supra n. 68) 23-24; Becker (supra n. 68); Soles lacedaemonius; minerals like lapis lazuli, hematite, and red and green marbles (often called jaspers, or antico verde and antico rosso); and especially the silicates: translucent brown agate, light blue chalcedony, red sard, transparent red cornelian, purple amethyst, and clear rock crystal. These new materials allow fine and sharp engraving that can take on sculp. tural nuances of great variety, color, and depth.

Most of the harder stones were imported, although their source is not always certain: rich brown agate from Egypt or even Idar-Oberstein in central Germany; breccia and amethyst should come from Egypt, cornelian from the Sinai or Mesopotamia, hematite from Mesopotamia, a light brown agate from Cambay in western India, and lapis lazuli from Afghanistan. It is possible that some rock crystal may have been local to Crete, but it was also available from Mesopotamia. ${ }^{102}$ Only lapis lacedaemonius from Krokeai south of Sparta and both antico verde and antico rosso from Cape Tainaron are certain to be local to the Aegean, and these three stones were probably imported to Crete via Kythera. ${ }^{103}$

Sealstones. At the heart of most of the artistic developments of the Neopalatial period is the "glyptic revolution" (late MM II-early MM III): the introduction of the horizontal bow-lathe in sealstone engraving, which allowed the cutting of hard stones and a greater subtlety in modeling. ${ }^{104}$ Moving the seal against the drill demanded convex surfaces to allow the artist to see clearly the point of contact; thus new shapes were developed. By the end of MM III, biconvex forms - lentoids, amygdaloids, and cushionsdominate the repertory.

The new technique, coupled with the Minoan ability to visualize sculpture in terms of both negative (intaglio) and positive (relief) space, affected a wide range of Minoan crafts: carving in ivory and wood,

\footnotetext{
(supra n. 68).

102 J.G. Younger, "Semi-Precious Stones to the Aegean," ArchNews 8:2-3 (1979) 40-44. Agate: P. Yule and K. Schürmann Yule, CMS Beiheft 1 (Berlin 1981) 273-82; and G.L. Possehl, Expedition 23:4 (1981) 39-46. Lapis lazuli: L. von Rosen, Lapis Lazuli in Geological Contexts and in Ancient Written Sources (SIMA-PB 65, Partille 1988). Rock crystal: S. Marinatos, ArchEph 1931, 158-60.

${ }^{103}$ Archanes 35; P. Warren, "Lapis Lacedaemonius," in

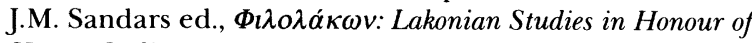
Hector Catling (Exeter 1992) 285-96.

${ }^{104}$ J.G. Younger, Bronze Age Aegean Seals in Their Middle Phase (ca. 1700-1550 B.C.) (SIMA 102, Jonsered 1993) 179-84, charts V-VIII; P.R.S. Moorey, Ancient Mesopotamian Materials and Industries (Oxford 1994) 74-103.
} 
sculpted stone relief vases, relief decoration of metal vessels (both cast and repoussé), the use of intaglio molds to produce faience, glass, and metal objects, including jewelry, and the molding of ceramic relief on pottery ${ }^{105}$ and painted plaster relief.

Technical and stylistic analyses of MBA and LBA seals have produced a fairly reliable stylistic chronology (fig. 5). ${ }^{106}$ Sealstone engravers, continuing the figural and narrative compositions developed first in the MM II Mallia Workshop, began immediately to experiment with the finer sculpting qualities that the hard stones presented. By the end of MM III the richly modeled seals in the Chanting Priest group present impressive studies of the human figure.

In LM I two stylistic groups dominate: in the hard stones, the Mycenae-Vapheio Lion group, and in soft stones, the Cretan Popular group. The MycenaeVapheio Lion group exhibits a monumental style: the lions and bulls have powerful muscles and pronounced saphenous veins, while the lions also have flame-lock manes whose edges are articulated like fish gills. The seals are fairly common on the Greek mainland (e.g., the Shaft Graves at Mycenae and the Vapheio tholos) and rare in Crete. The Cretan Popular group consists of serpentine seals often depicting simple animals, monsters (e.g., the common birdwoman), and people in cult scenes. Contemporary with these seals are those used to impress the sealings in House A at Zakros. ${ }^{107}$

The monumental style of the Mycenae-Vapheio Lion group continues into the LM IB period in a series of groups collectively termed Almond-Eyes; typical seals show sleekly modeled bulls. Starting just before the end of the Neopalatial period and continuing into LM II, the so-called Dot-Eyes seals depict bulls whose modeling is dry and plain. Almost all these seals are made of hard stones; there is virtually no soft stone group of seals after the Cretan 1982).

${ }^{105}$ K.P. Foster, Minoan Ceramic Relief (SIMA 54, Göteborg

${ }^{106}$ J.H. Betts and J.G. Younger, "Aegean Seals of the Late Bronze Age: Masters and Workshops, I: Introduction," Kad mos 21 (1982) 104-21; Younger, "Aegean Seals of the Late Bronze Age: Stylistic Groups," a series in Kadmos: 22 (1983) 109-36; 23 (1984) 38-64; 24 (1985) 34-73; 25 (1986) 119-40; 26 (1987) 44-73; 28 (1989) 101-36; Younger, The Iconography of Late Minoan-Mycenaean Sealstones and Finger Rings (Bristol 1988).

${ }^{107} \mathrm{~J}$. Weingarten, The Zakro Master and His Place in Prehistory (SIMA-PB 26, Göteborg 1983). One sealstone from this group has survived, CMS XI, no. 164.

${ }^{108}$ J.H. Betts, in Popham et al. (supra n. 5) 192-93.

109 Younger 1983 (supra n. 106) 124-25.
Popular group until the Mycenaean Mainland Popular group datable to LH IIIA2-B1. Further developments in Minoan seals are discussed below in the section on Final Palatial art.

It is likely that seals were considered personal possessions and that a person could own, in some fashion, several. The large numbers of seals in the soft stone classes, the Mallia Workshop group in the Protopalatial period and the Cretan Popular group in Neopalatial times, found throughout settlement areas and in domestic contexts make it certain that the practice of owning and wearing seals was not restricted to the upper classes. ${ }^{108}$ Since steatite and serpentine are commonly available in Crete, the manufacture and distribution of soft stone seals might not have been under administrative control, although a few seals in the Cretan Popular group were used to impress nodules found at Knossos and elsewhere. ${ }^{109}$ Since the hard stone seals were made from imported material, it is likely that the regional centers commissioned artists to make them; if so, administrators may have dispensed these seals, perhaps at formal occasions. Among the many representations of people wearing jewelry and strung beads, a few depict women and men wearing a single circular bead, probably a lentoid seal, on a bracelet at their wrist. ${ }^{110}$

In addition to their administrative uses, seals probably also functioned as amulets, ${ }^{111}$ and markers of status. The relationship between a seal's iconography and its owner's administrative function has not been much studied, ${ }^{112}$ although it is assumed that gold rings with cult scenes, discussed below, probably belonged to elite members of Minoan society. It is likely, too, that seals functioned politically, with a sealstone iconography or style more popular or appropriate in one region than in another. Thus, during LM I the odd monsters by the Zakros Master would have

${ }^{110}$ P. Rehak, "The Aegean 'Priest' on CMS I 223," Kadmos 23 (1994) 76-84; J.G. Younger, "Representations of Minoan-Mycenaean Jewelry," in Eikon 257-93, esp. 266-68.

111 C. Bonner, Studies in Magical Amulets (Ann Arbor 1950 ); E.A. Wallis Budge, Amulets and Superstitions (London 1930) 12, 306-30; J.G. Younger, "Non-Sphragistic Uses of Minoan-Mycenaean Sealstones and Rings," Kadmos 16 (1977) 141-59.

112 Some scholars assume a direct relationship: I. KilianDirlmeier, "Das Kuppelgrab von Vapheio," JRGZM 34 (1987) 197-212; H. Wingerath, Studien zur Darstellung des Menschen in der minoischen Kunst der älteren und jüngeren Palastzeit (Mar. burg 1995) 147-48. For a summary of more complex views, see J.G. Younger, "Seals and Sealing Practices: The Ancient Near East and Bronze Age Aegean," AJA 100 (1996) 161-65. 


\section{SEAL SHAPES}

DISK

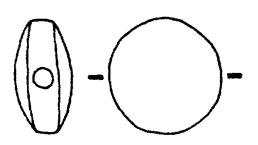

LENTOID

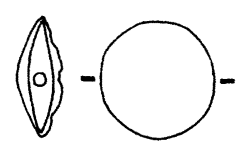

AMYGDALOID

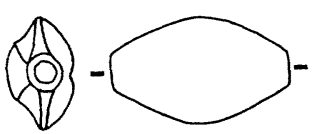

CUSHION

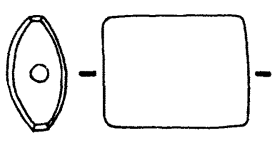

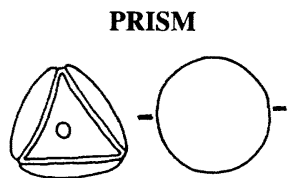

RING

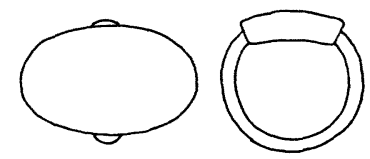

MINOAN CLAY DOCUMENT TYPES

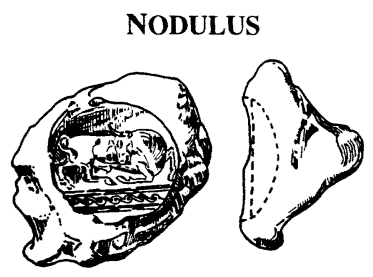

FLAT BASED NODULE

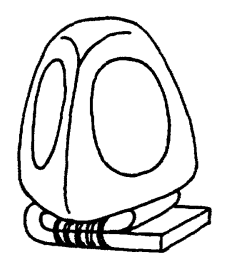

1-HOLE HANGING NODULE

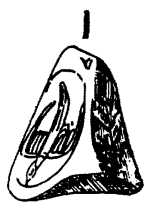

independent documents (not attached)
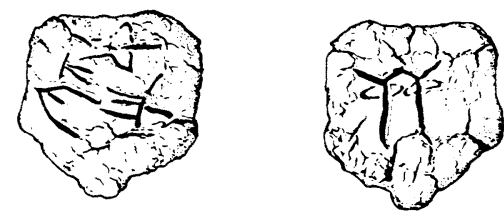

ClAY BAR
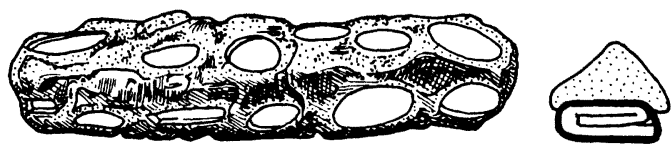

2-HOLE HANGING NODULE

hanging nodules

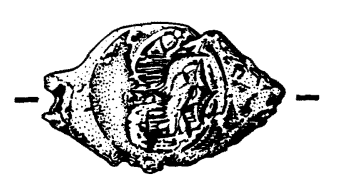

MYCENAEAN CLAY DOCUMENT TYPES direct object sealings
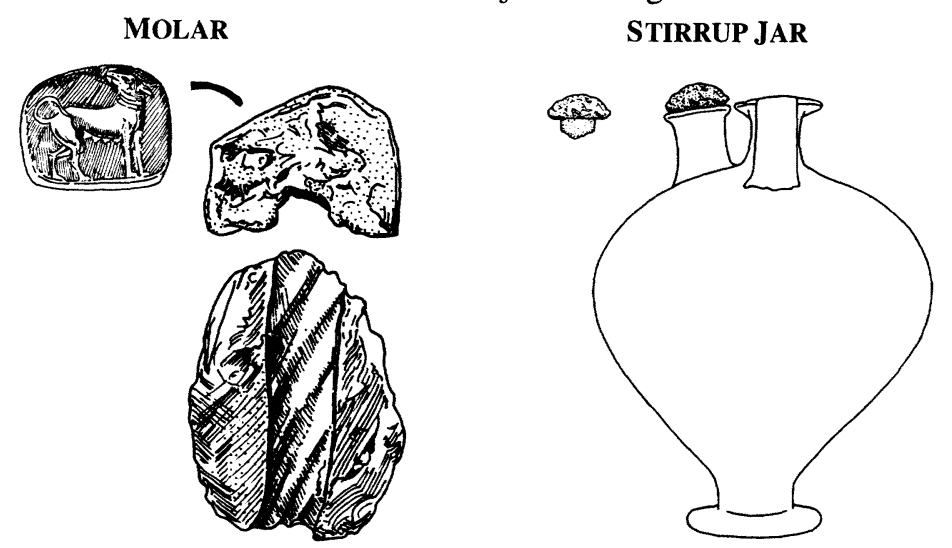

hanging nodule

$\underset{\text { 2-HOLE WICKER }}{\text { IMPRESSION }}$
INSCRIBED
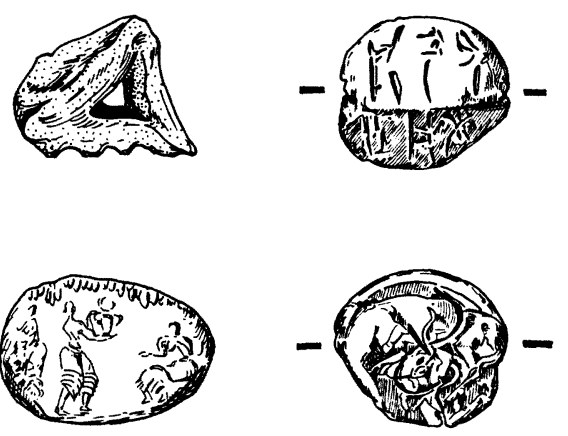

Fig. 5. Diagram of seals, sealings, and clay documents. (P. Rehak and J.G. Younger; drawn by P. Rehak) 
identified Zakros, and different types of bulls might have distinguished Chania from Knossos. ${ }^{113}$

Reliefs. Seals represent art on a miniature scale, but the technological and conceptual advances that began there soon spread to other media. Stoneworkers also carved large-scale figural reliefs, though only two have survived, the pair of gypsum plaques removed from Mycenae by Lord Elgin. ${ }^{114}$ They probably had been exported from Knossos as spolia to decorate the facade of the Treasury of Atreus ( $\mathrm{LH}$ IIIA1-2), long after their original manufacture. ${ }^{115}$ The two reliefs are less than half life-size and depict a bovine standing to left and a bovine running to right.

Most other sculpted plaques, however, are decorative architectural friezes, limited to the Knossos area and difficult to date. Several segments of limestone and colored marble carved with a triglyph-half rosette pattern, rosettes, running spirals with dot centers, or plain dado slabs with moldings along their edges once decorated the palace. ${ }^{116}$ Fragments of column capitals carved in relief with floral petals were found in the central court: these have flat backs and mortices and so must have been nonsupporting revetments attached to a flat wall surface. Some Neopalatial frescoes and relief frescoes show the triglyphhalf rosette motif as part of the facade of palaces or shrines, ${ }^{117}$ and it is reasonable to assume that stone and wooden friezes with these designs existed contemporaneously.

Stone vessels and other objects. Stone vases come in many shapes ranging from the purely utilitarian cups, bowls, and buckets to the more decorative blossom bowls and relief rhyta. Because of their dura-

113 B.P. Hallager and E. Hallager, "The Knossian BullPolitical Propaganda in Neo-Palatial Crete?" in Politeia 547-56.

${ }^{114}$ J.G. Younger, "The Elgin Plaques from the Treasury of Atreus," in W. Schiering ed., Kolloquium zur ägäischen Vorgeschichte (Mannheim 1987) 138-50.

115 E.B. French, "'Dynamis' in the Archaeological Record at Mycenae," in M.M. Mackenzie and C. Roueché eds., Images of Authority (Cambridge 1989) 122-30, esp. 124-25.

${ }^{116}$ PM II.1, figs. 83-84; II.2, figs. 368, 372, and 436; IV.1, figs. 172, 174, 175, and 191a-b; $A R 3$ (1957) 21, figs. 18-19.

${ }^{117}$ E.g., $P M$ II.2, 597 fig. 371 and 604 fig. 377; III col. pl. XVI.

${ }^{118}$ Warren (supra n. 68), rev. by E.T. Vermeule, $C J 69$ (1973-1974) 177-80. For repairs, see, e.g., a spouted serpentine bowl found at Knossos: Catling et al. (supra n. 50) 56, 58 fig. $41.2,59$ no. S2, pl. 13.

119 P.P. Betancourt, "The Trade Route for Ghyali Obsidian," in Techne 171-75; C. Renfrew, J.R. Cann, and J.E. Dixon, "Obsidian in the Aegean," BSA 60 (1965) 50-72.

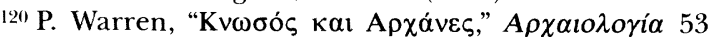
(1994) 57-67, 67 col. fig.

${ }^{121}$ E.g., inlays for the gaming-board from Knossos, the bility some vessels survived for centuries, and when broken they were frequently repaired or their frag. ments sometimes saved. ${ }^{118}$ While serpentine and steatite were most common, artisans employed a range of harder ornamental stones, including banded limestone from Kakon Oros ("banded tufa"), east of Amnisos, lapis lacedaemonius and antico rosso from Laconia, and the white-spotted obsidian from the island of Giali off the coast of Asia Minor. ${ }^{119}$ Un. worked lumps of antico rosso have been found at the peak sanctuary on Kythera and at Archanes Tourkogeitonia. ${ }^{120}$ Although amethyst and rock crystal were more commonly used for beads, jewelry, seals, and inlays, ${ }^{121}$ these materials were occasionally also used for special vases. Amethyst was used for two triton fragments from Mycenae and Midea, probably of Neopalatial origin though found in later contexts, and rock crystal was used for a variety of vessels, including a rhyton from Zakros. ${ }^{122}$

Elaborately shaped vessels were pieced together from several pieces of stone. Attached handles are common, but several vessels also have attached necks and spouts. One globular jug from the Zakros palace is of veined limestone with a separately added neck and two curving handles attached to the body with bronze wires; similar vases are represented on sealstones. ${ }^{123} \mathrm{~A}$ distinctive shape of stone vessel is the large, footed drinking cup or chalice. ${ }^{124}$ The most spectacular surviving example, of spotted Giali obsidian, was found in the west wing of the Zakros palace. These may be palatial versions of the similarly shaped terracotta chalices, some with applied surface decoration, that have been found in large numbers at the Kato Syme sanctuary. ${ }^{125}$ From Thera

Temple Repositories (PM I, 470-81), and for the eyes of the bull's head rhyton from the Little Palace. A rectangu. lar plaque from Knossos is painted on the back with a bullleaping scene (PM III, 108-11, col. pl. XIX). See now D. Plantzos, "Crystals and Lenses in the Graeco-Roman World," AJA 101 (1997) 451-64.

${ }^{122}$ K. Demakopoulou, N. Divari-Valakou, and G. Walberg, OpAth 20 (1994) 32, 34, fig. 45; Demakopoulou, in Aegean and Orient; PM III, 410 fig. 272a-b (crystal from Knossos); Zakros 139 col. fig. (upper right). The lower half of a crystal cup from Palaikastro is on display in Herakleion.

${ }^{123}$ Zakros 10 col. fig.; cf. the rhyton of white marble from Mycenae SG IV. For sealstones, see Metaxa-Muhly (supra n. 95) 100 , pl. 32 no. 302 , pl. 33 no. 303.

124 Zakros: $P G C$ 92-93, nos. 1152 and 1155; Thera: $P G C$ 92-93, nos. 1153 and 1154; Mycenae SG IV and V: Karo nos. 600, 854; Pseira: HM 1123; Knossos: PM II.1, 127 fig. 62a; and Makriyialos: C. Davaras, Hagios Nikolaos Museum (Athens n.d.) col. fig. 48.

${ }^{125}$ A. Lembesi and P. Muhly, "Aspects of Minoan Cult: Sacred Enclosures. The Evidence from the Syme Sanctuary (Crete)," $A A$ 1990, 315-36, esp. 325, figs. 10-11. 
and the mainland come chalices that are shorter and of calcite ("alabaster"). Another special class of stone vessel consists of stone imitations of shells, especially triton shells. ${ }^{126}$ One such probable trumpet is the dark steatite triton from Mallia displaying marine rockwork and a low relief composition of two genii. ${ }^{127}$

Imported baggy and ovoid alabastra of veined calcite were occasionally modified by Minoan artisans once the vessels had reached Crete, and are thus a sign of trade and intercultural contacts as well as of Minoan aesthetics. These have usually been considered Egyptian, but recently Lilyquist has suggested that some may be Syrian, and similar vessels were exchanged as prestige objects throughout the Near East. ${ }^{128}$ One predynastic vase from the Zakros palace had been "Minoanized" through the addition of a typical Cretan beaked spout. ${ }^{129}$ Another vessel, an alabastron, had been inverted in Crete, its original mouth plugged for a foot and its body outfitted with new handles and a spout; so modified, it was then sent on to Mycenae where it was deposited in Shaft Grave V.130

Black or green steatite, green chlorite, and white or colored limestones were often used to make rhyta in several shapes that imitate pottery funnels: globular, ovoid, piriform, and conical. Rhyta and other stone vessels are common finds in the palaces and major villas, even occurring in sets like those from the Sanctuary Hall deposit at the Knossos palace, Ayia Triada, ${ }^{131}$ and the Zakros palace, where they may have been paired with chalices of similar stone.

A special class of rhyta takes the form of the heads of bovines or lions. ${ }^{132}$ These heads were often inlaid with other materials for color contrast and to enhance their value. Since the Little Palace bull's head was found built into a wall it may have been part of a deliberate foundation deposit. Fragmentary lion-

\footnotetext{
${ }^{126}$ J.G. Younger, Aegean Music (SIMA-PB 144, in preparation); for examples, see $C M$ pl. 115 (below), and Halbherr et al. (supra n. 31) 90 fig. 57.

${ }^{127}$ C. Baurain and P. Darcque, $B C H 107$ (1983) 3-73.

${ }^{128}$ P. Warren, "The Lapidary Art - Minoan Adaptations of Egyptian Stone Vessels," in Techne 209-23; cf. C. Lilyquist's response: Techne 225-28.

${ }^{129}$ Zakros 138 col. fig. (top); cf. PM IV.2, 976, Suppl. pl. LXVIa from the Temple Tomb at Knossos.

${ }^{130}$ Karo 147 no. 829, pl. CXXXVII. Cline 5-6 calls it an 18th Dynasty vessel, but Manning 1995 (supra n. 16) 229 notes that V. Hankey has identified it as a Middle Kingdom "drop vase." At the Techne conference in 1996, P. Warren mentioned that the plug was not cemented in place: the vessel could not have been used to contain a liquid.

${ }^{131}$ E.g., Halbherr et al. (supra n. 31) 60 fig. 28; 66 fig. 32; 84, 86 fig. 53.

132 Bovines: P. Rehak, "The Use and Destruction of Mi-
}

and lioness-head rhyta of white limestone were found in the Knossos palace; a piece of the muzzle of a third was discovered under the Temple of Apollo at Delphi.

Some stone rhyta have pictorial compositions carved in low relief on their outer surface. ${ }^{133}$ Only a few themes are represented: marine motifs, bull sports, combats and warfare, cult scenes in architectural settings suggesting palaces or peak sanctuaries, and possibly hunting scenes. The most discussed of these vessels is the Sanctuary Rhyton from Zakros. ${ }^{134}$ A recent addition to the corpus is a fragment with dolphins from a well at Palaikastro (fig. 6). Some of these themes are also found in gold and silver plate, like the silver Siege Rhyton from Mycenae and the gold cups from the Vapheio tholos. ${ }^{135}$ The most unusual aspect of these stone relief rhyta is that when human figures are included only men are shown, perhaps indicating that only men made and used them. The presence of some warlike elements also indicates clearly that militarism was a Minoan, and not just a Mycenaean, feature early in the Late Bronze Age. Koehl has suggested that one vessel, the Chieftain Cup from Ayia Triada, played a specific role in a male initiation rite. ${ }^{136}$

Relief rhyta are often discussed mainly for their artistic and iconographic value; their use remains problematic. Liquids poured in at the top would drain out at the bottom, unless a fingertip was held over the lower opening. It is usually assumed that rhyta served as wine vessels: the larger ones could have provided up to 30 servings in small conical drinking cups, but they would also have been extraordinarily heavy. ${ }^{137}$

Almost all relief rhyta and bovine-head rhyta, however, are found in fragments, in contrast to the many complete plain stone rhyta. It has therefore been suggested that the relief vessels may have been de

noan Stone Bull's Head Rhyta," in Politeia 435-60. For the fragment from Zakros with gilded nostrils, add Prakt 1972, 180, pl. 169 $\alpha-\beta$. Lions: PM II.2, 827-34, 828 figs. 542a-b, 549; CM pl. 99; S. Marinatos and M. Hirmer, Kreta, Thera und das mykenische Hellas (Munich 1976) pl. 99; PGC 102 no. 1237, pl. 1237; Warren (supra n. 68) 90 (type E).

${ }_{133}$ B. Kaiser, Untersuchungen zum minoischen Relief (Bonn 1976), with updates: P. Rehak, "The Ritual Destruction of Minoan Art?" ArchNews 19 (1994) 1-6.

${ }^{134}$ J.W. Shaw, "Evidence for the Minoan Tripartite Shrine," AJA 82 (1978) 429-48; P. Rehak and J.G. Younger, AJA 98 (1994) 306-307 (abstract).

${ }^{135}$ E. Davis, The Vapheio Cups and Aegean Gold and Silver Ware (New York 1977) nos. 87, 103, and 104.

${ }^{136}$ R.B. Koehl, "The Chieftain Cup and a Minoan Rite of Passage," JHS 106 (1986) 99-110.

${ }^{137}$ The Boxer Rhyton: D. $17 \mathrm{~cm}$; H. $45.5 \mathrm{~cm}$, weighing ca. $1 \mathrm{~kg}$ empty and $3 \mathrm{~kg}$ full. 


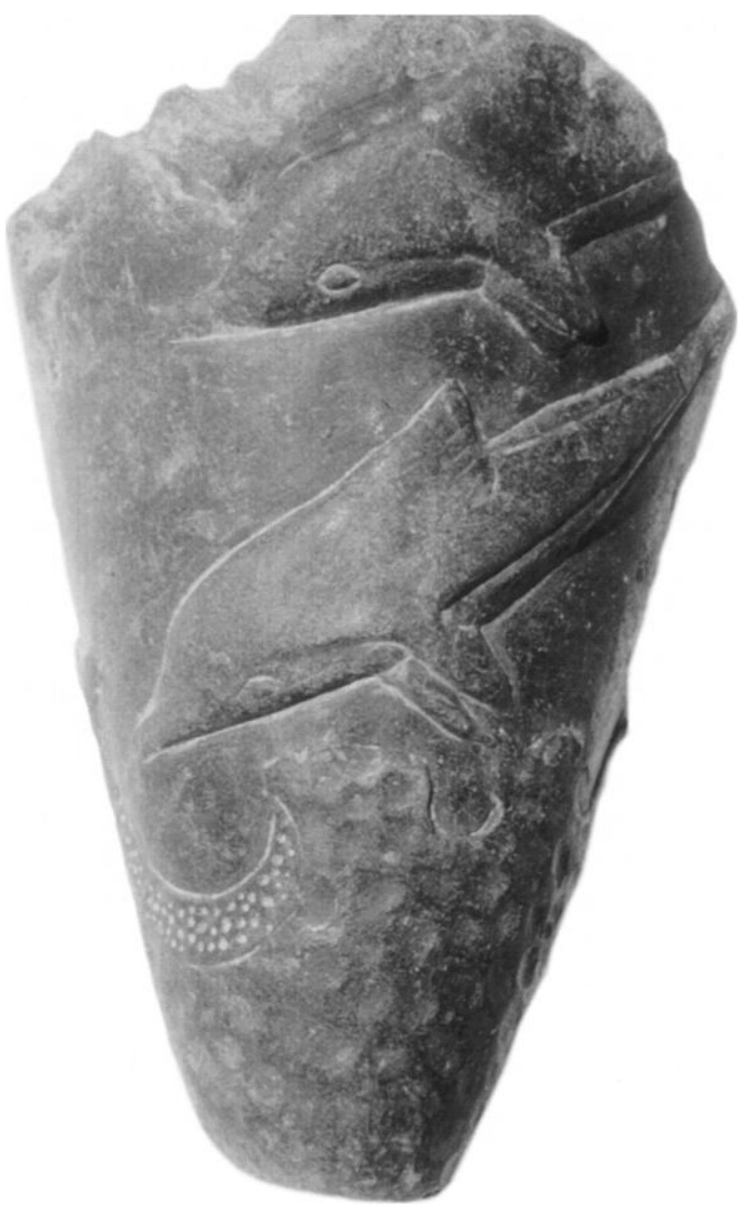

Fig. 6. Rhyton fragment from Palaikastro. (Courtesy L.H. Sackett and J.A. MacGillivray)

liberately destroyed after use as part of a social or religious ceremony and the fragments taken as tokens by the participants, ${ }^{138}$ though the new Palaikastro fragment was found discarded in a well. Several of the surviving fragments are from LM IA contexts, indicating that at least some of the relief rhyta had been reduced to pieces before the end of the Neopalatial period.

${ }^{138}$ Rehak (supra ns. 132-33). Cf. R. Bradley, “The Destruction of Wealth in Later Prehistory," Man 17 (1982) 108-22.

139 P. Muhly, Minoan Libation Tables (Diss. Bryn Mawr College 1981); I. Schoep, "Ritual, Politics and Script on Minoan Crete," Aegean Archaeology 1 (1994) 7-25. Kato Syme: $A R 36$ (1990) 72; Lembesi and Muhly (supra n. 125) 342 fig. 12. Juktas: Prakt 1975, pl. 264 $\varsigma^{\prime}$. Psychro: ArchDelt 37 B1 (1982) pl. 276y. Knossos: AR 3 (1957) 22-23, fig. 7.

${ }^{140}$ E.g., B. Kaiser, "Mykenische Steingefässe und verwandtes im Magazin zu Nauplia," AM 95 (1980) 1-19.

${ }^{141}$ L.N. Platon and Y. Pararas, Pedestalled Offering Tables in the Aegean World (SIMA-PB 106, Göteborg 1991). From Kato Syme: Lembesi and Muhly (supra n. 125) 330-31, figs.
Steatite or serpentine was also used for offering tables in a variety of shapes. A small percentage of these are inscribed in Linear A, and both inscribed and uninscribed offering tables are often found in peak sanctuaries and caves, less often at habitation sites. ${ }^{139}$ An incurved example with a circular depression in the top was found in a house shrine at Knossos; the hollowed upper surface may have served as a kernos. Miniature versions of such kernoi have been found in the peak sanctuary on Mt. Juktas. Some kernoi have multiple depressions, presumably for pinches of different kinds of grain or spice, while others have small cupules that communicate with a larger, central depression, suggesting liquid offerings. Only a few examples of offering tables have been found on the mainland, all of them probably imported from Crete. ${ }^{140}$ Some offering tables are parts of composite offering stands, like a serpentine example found at Kato Syme: the table fits atop another block with moldings and a dowel in its upper and lower surfaces, and this fits atop a serpentine pier. $^{141}$

Another type of offering vessel, rounded at one end, tapering to a pointed tip at the other, has been called a "ladle", and is sometimes inscribed in Linear A. ${ }^{142}$ Although some have been found in habitation sites, like the offering tables they seem to have been meant for use at peak sanctuaries, and many miniature ladles, perhaps votives, were found on $\mathrm{Mt}$. Juktas. One relief rhyton fragment shows two men in procession carrying ladles toward a shrine at a higher level. ${ }^{143}$ The suggestion has been made that ladles were used to pour liquid offerings, perhaps oil or wine, into the offering tables or kernoi. ${ }^{144}$ If the ladles and offering tables, as well as relief rhyta, were used exclusively by men, we have an important example of the gendered use of certain types of ritual vessel.

Also distinctive are Neopalatial stone, hammershaped "mace-heads" found on Crete and at a few

$19-22$.

142 Stone ladle from Knossos: PM II.2, 439 fig. 256c; and from Juktas: Prakt 1975, pl. 265ß, and on display in the Herakleion Museum. Clay ladle from Knossos palace: $P M$ I, 624 fig. 460. Inscribed examples: Archanes: GORILA 4, TL Zc 1; PM I, 625 fig. 462; Archanes 52 col. fig. 30. Juktas: $P M$ I, 624 fig. 461 (the inscription A.JE-SA looks like a botched attempt to start JA-SA-SA-RA). Kythera: GORILA 4, KY Zc 2; I.A. Sakellarakis and J.P. Olivier, BCH 118 (1994) 343-51.

14. PM III, 65 fig. 37.

${ }^{144}$ K. Nikolidaki and G. Owens, "The Minoan Libation Formula," Cretan Studies 4 (1994) 149-55, esp. 152-53. 
other Aegean sites. ${ }^{145}$ A sealstone from Mallia shows a robed figure apparently holding such a mace, which may be a sign of status or insigne of office, as similar objects were in Syria and Egypt. ${ }^{146}$ The shape also inspired a terracotta rhyton. ${ }^{147}$ Only one of the Cretan examples comes from a context later than LM IB, and its form is spherical. ${ }^{148}$

Lamps come in a variety of stones and shapes; beginning in MM II, they become more elaborate in the Neopalatial period. ${ }^{149}$ Most lamps have a shallow bowl for oil and have one to four depressions on the lip for the wick. Some lamps have short pedestals, while others were attached to columnar supports, the surface of which was occasionally carved in relief. A few lamps have been found outside Crete, especially at Mycenae, though one elaborate lamp comes from the palace at Alalakh. In Crete elaborate stone lamps come from Minoan halls, pillar basements, and other specialized rooms where they may have had a ritual function.

Limestone and gypsum stands or bases are usually trapezoidal in section with a hole in the top; double axes could, on analogy with the depiction on the later Ayia Triada sarcophagus, be inserted in the base. Bases with incurved sides have been found at a few sites. ${ }^{150}$ In a few frescoes incurved

${ }^{145}$ From Crete: N. Mante-Platonos, ArchEph 1981, 74-83. From Aegina: C. Reinhold, ArchKorrBlatt 22 (1992) 57-62. In the Nauplion Museum: Kaiser (supra n. 140) esp. 16 no. M69:40, 17 fig. 4, pl. 7.4. For a different stone hammer-ax from a chamber tomb at Poros Herakleion, see MetaxaMuhly (supra n. 95) 96 no. 284, pl. 31 no. 284.

146 CMS II.3, no. 147. Two maces were found in the lomb of the "Lord of the Goats" at Ebla: M.G. Scandone, Studi Eblaiti 1 (1979) 119-28; Scandone, in Studies in the History and Archaeology of Palestine 2 (Aleppo 1986) 49-55. C. Lily. quist informs us (personal communication) that the mace may be a Syrian imitation of an Egyptian object.

${ }_{147}$ W. Schiering, "Ein minoisches Tonrhyton in Ham. merform," CretChron 24 (1972) 476-86.

${ }^{14 \times}$ Tomb of the Mace Bearer at Knossos (LM II-IIIA): A.J. Evans, "The Tomb of the Double Axes," Archaeologia 65 (1914) 18 fig. 25; PM IV.1, 356 fig. 299. A similar lapis lacedaemonius mace-head, apparently from the Zakros palace, was on display in the Siteia Museum in 1996.

149 MM II: Detournay et al. (supra n. 99) 59-60 no. 95, 60 fig. 79. MM III: $P M$ II.1, 298 fig. 174. A. Blasingham, $A J A$ 99 (1995) 334 and AJA 100 (1996) 366 (abstracts); Blasing. ham, "Minoan Lamps in Domestic Contexts," 8th CretCong (forthcoming). Elaborate lamps do not long survive LM IB, if at all. Archanes Tourkogeitonia: Archanes $35 \mathrm{col}$. fig. 18; and Ergon 1989, 144 fig. 135 (in situ); Ayia Triada: CM pl. 115 (above); Halbherr et al. (supra n. 31) 71 fig. 41,75 fig. 46, 167 fig. 105. Zakros: Zakros 139 col. fig. (below), 149 fig. (above). Knossos: PM II.1, 124 fig. 59; II.2, 481 fig. 288a. Juktas: $A R 36$ (1990) 71. Mainland: Vapheio tholos on display in the National Museum; Mycenae Lion tholos (R. Hampe and E. Simon, The Birth of Greek Art [Oxford 1981] bases could also serve an architectural function, ${ }^{151}$ primarily as supports for platforms upon which a goddess may sit or griffins may recline or for a column flanked by lions as on the Lion Gate relief from Mycenae. A unique large, pierced, porphyry pyramid from Knossos is probably a talent-weight. ${ }^{152}$ It is carved with an octopus on one side, its tentacles embracing the other sides.

Ivories. Elephant and especially hippopotamus ivory had been imported from Syria or perhaps Egypt in the Early Bronze Age through a system of longdistance trade networks with the eastern Mediterranean. ${ }^{153}$ Though evidence for Protopalatial ivory carving is scanty, in the Neopalatial period the carving of ivory is conducted on a large scale. A carved ivory disk found at Palaikastro, but possibly Cypriot in manufacture, and several uncarved elephant tusks from the Zakros palace attest to trade, and several workshops at the palaces handled ivory and other exotic materials. ${ }^{154}$ Ivory was most often used for furniture inlays and cosmetic objects (especially jew. elry boxes and mirror handles), as well as for a small group of figurines.

There is little evidence for the creation of large pieces of ivory furniture like beds and chairs, ${ }^{155}$ but a small ivory footstool volute has been found at

fig. 201); Nauplion Museum: Kaiser (supra n. 140). Alalakh: L. Woolley, Alalakh (Oxford 1955) 294-95, pl. LXXIX.

${ }^{150)}$ Archanes: Archanes 32 fig. 16. Knossos: PM IV.1, 209 and fig. 160a.

151 M.C. Shaw, "The Lion Gate Relief of Mycenae Recon.

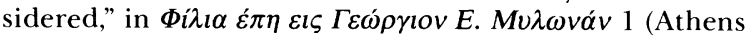
1986) 108-23; PM III, 207 fig. 141; Doumas pl. 122; CMS I, no. 282.

${ }^{152}$ H. $42 \mathrm{~cm}$; W. $27 \mathrm{~cm}$; Th. $13 \mathrm{~cm}$; Wt. 28.6 kg. Cf. K. Petruso, Keos VIII: Ayia Irini: The Balance Weights (Mainz 1992) 38 no. 73.

153 P. Rehak and J.G. Younger, "International Styles in Ivory Carving in the Bronze Age: The Aegean and the East," in Aegean and Orient; J.C. Poursat, Catalogue des ivoires mycéniens du Musée National d'Athènes (Paris 1977); Poursat, Les ivoires mycéniens (Paris 1977); Poursat, "Ivory Carving in Minoan Crete (2000-1450 B.C.)," in J.L. Fitton ed., Ivory in Greece and the Eastern Mediterranean from the Bronze Age to the Hellenistic Period (London 1992) 3-5. O.H. Krzyszkowska, "Ivory in the Aegean Bronze Age: Elephant Tusk or Hippopotamus Ivory?” BSA 83 (1988) 209-34; Krzyszkowska, Ivory and Related Materials (London 1990).

154 Palaikastro: J.A. MacGillivray et al., BSA 84 (1989) 426 n. 8; D. Evely, "Seeing Is Believing?" in Techne 463-65; Zakros: Zakros 210-21. Knossos: AR 4 (1958) 21-22; AR 5 (1959) 20; AR 6 (1960) 24; AR 7 (1961) 26-27. Archanes: ArchEph 1991, 214 fig. 44: arm and hand, 217 fig. 46: leg and foot; Archanes 46 col. fig. 24, 47 col. fig. 25.

155 O.H. Krzyszkowska, "Furniture in the Aegean Bronze Age," in G. Herrmann ed., The Furniture of Western Asia (Mainz 1996) 85-103. 
Zakros, the earliest example of a type that is better attested in LM/LH II-IIIA contexts. While the carv. ing of furniture relief plaques goes back to MM II Quartier Mu at Mallia, ${ }^{156}$ Neopalatial plaques and cutouts were used to decorate boxes, small chests, and other objects: butterflies, double axes (some combined with "sacral knots"), a house facade reminiscent of the faience Town Mosaic, and other plain or ornamented strips such as those that decorated the Knossos "game-board." 157

Cosmetic objects were also made of ivory, as they were in Syria and Egypt. Cylindrical pyxides, cut from a section of elephant tusk, carry decoration on their sides and sometimes the lid; the decoration is often figural (e.g., an incised cult scene with young girls on an ivory pyxis from Ayia Triada, a bull-hunt modeled in low relief from Katsamba) but also purely decorative (e.g., spirals from Kea). ${ }^{158}$ Other Neopalatial toilet articles are combs and mirror handles. ${ }^{159}$ Though many of these are found in later contexts and have been considered Mycenaean works, we sug. gest that most are Neopalatial instead. Three mirror handles from late contexts at Mycenae present pairs of young girls in short skirts and short coiffures holding flowers or ducks; their hairstyles and costumes resemble those of the girls on the Ayia Triada pyxis and the girls in the Thera frescoes. ${ }^{160}$ If these mir. ror handles are Neopalatial works, so is the technique of using rivets ornamented with lapis lazuli or blue glass disks surrounded by gold granulation to attach the handles.

The most intriguing and problematic ivories are the figurines carved in the round and usually pieced

\footnotetext{
156 Poursat 1992 (supra n. 153) 3-5, pl. 1.

${ }_{157}$ Zakros: E. Platon, in Eı $\lambda \alpha \pi i v \eta$ (supra n. 13) 209-26,
} figs. 1-9. S. Hood, The Arts in Prehistoric Greece (Harmondsworth 1978) 121 fig. 109 (heron); Zakros 131 and fig. (axes), 148 fig. (butterfly); Gesell 192 fig. 89 (sacral knot).

158 Ayia Triada: Halbherr et al. (supra n. 31) 97-98, figs. 64-65. Katsamba (LM II-IIIA): Poursat, Les ivoires (supra

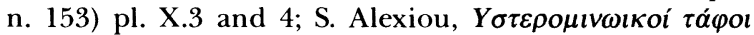
$\lambda_{\mu} \mu \varepsilon \dot{v o \varsigma} K v \omega \sigma o u ́(K \alpha \tau \sigma \alpha \mu \pi \alpha ́)$ (Athens 1967) col. frontispiece, pls. 30-33; J.C. Poursat, "Les ivoires mycéniens," DossPar 195 (1994) 90 col. fig. Kea: W.W. Cummer and E. Schofield, Keos III: Ayia Irini: House A (Mainz 1984) 95 no. 1083, pl. 41.

${ }^{159}$ A. Papaefthimiou-Papanthimou, $\Sigma \kappa \varepsilon u ́ \eta ~ \kappa \alpha \iota ~ \sigma u ́ v \varepsilon \rho \gamma \alpha$

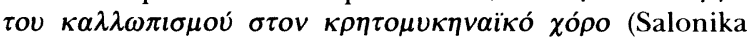
1979); A.P. Iliaki, Mycenaean Ivories (Diss. Bryn Mawr College 1976). An ivory comb from Knossos, Royal Road (LM IB): $A R 7$ (1961) 27.

${ }^{160}$ Poursat, Catalogue (supra n. 153) no. 300 from Myce. nae chamber tomb 55, and nos. 331 and 332 from Clytem nestra Tholos dromos; E.N. Davis, "Youth and Age in the Thera Frescoes," AJA 90 (1986) 399-406; D. Withee, AJA 96 (1992) 336 (abstract); Younger (supra n. 110) 288-89.

${ }^{161} P M$ III, 428-30 and II.2, 727 fig. 455; $A R 7$ (1961) 29 together from several pieces of hippopotamus incisor; these figures may have formed vignettes, sometimes of bull-leapers. ${ }^{161}$ Examples have been found in the Knossos palace, along the Royal Road, at Ar. chanes, Mallia (Chrysolakkos), and Palaikastro. The recently discovered Palaikastro ivory youth (fig. 7) had ivory flesh (one arm at least was overlaid with gold), inlaid nipples, crystal eyes, gold clothing, and an incised "wig" of black steatite. ${ }^{162}$ The ivory figure's pose with elbows bent and hands clenched below the pectorals mimics that of MM II terracotta figurines from nearby Petsofa; it recurs rarely. ${ }^{163}$ The shaved head with a single thick lock of hair braided down the middle characterizes the youth as adolescent rather than adult. ${ }^{164}$ Since ivories and relief frescoes from Knossos usually depict fingernails, veins, and an elongated thumb, the occurrence of these traits on the Palaikastro youth suggests that he was commissioned from there. ${ }^{165}$ One serious problem with the youth, however, is that at present it consists of two nonjoining halves with the tenon at the bottom of the torso having no corresponding mortise in the upper surface of the hip. Since no satisfactory reconstruction of the costume has been published for the intervening gap, the restoration of the figure, as well as its proportions, remains problematic.

None of the Neopalatial figurines from archaeological contexts is immediately identifiable as female, and it is likely that all of the ivory "goddesses" on the art market early in the 20th century are fakes. ${ }^{166}$ A probable Neopalatial work that does depict women, however, is the Ivory Triad that comes

fig. 40 .

162 L.H. Sackett and J.A. MacGillivray, Archaeology 42.5 (1989) 26-31; MacGillivray et al. (supra n. 154) 426-27, 427 fig. 7 (left foot), 428 fig. 8 (drawing of upper body), pls. 62-63; MacGillivray et al. 1991 (supra n. 50) 141-44; L.H. Sackett, AJA 95 (1991) 293 (abstract); AR 37 (1991) 74-75 fig. 72 (figure completed with legs); J.H. Musgrave, in Fitton (supra n. 153) 17-23 (with clear details); J. Weingarten, in Politeia 249-61. For steatite hair, cf. H. Weiss ed., Ebla to Damascus (Washington, D.C. 1985) 166-67 nos. 73-74.

${ }^{163}$ Ivory statuette: Poursat, Catalogue (supra n. 153) 87 no. 286 , pl. XXVI (cf. 116 no. 359 , pl. XXXVIII); bronze statuette: Lembesi and Muhly (supra n. 125) 326 fig. 14; sealstone: CMS V, no. 201. Petsofa: B. Rutkowski, Petsophas (Warsaw 1991) 22-29, pls. A-B, 3-18, and 20-22.

${ }^{164}$ Davis (supra n. 160); cf. the youth in a LM IA fresco from Xeste 3, Akrotiri: Doumas pls. 109, 113.

165 Ivories from Knossos, the palace: $P M$ III, 428-35; Royal Road: $A R 7$ (1961) 25-29; cf. the Priest King's elongated thumb: $P M$ II.2, 780 fig. 508.

${ }^{166} \mathrm{~K}$. Lapatin, "Minoan and 'Minoan' Chryselephantine Statuary," an unpublished paper given at the Techne con ference, Philadelphia, 18 April 1996. 


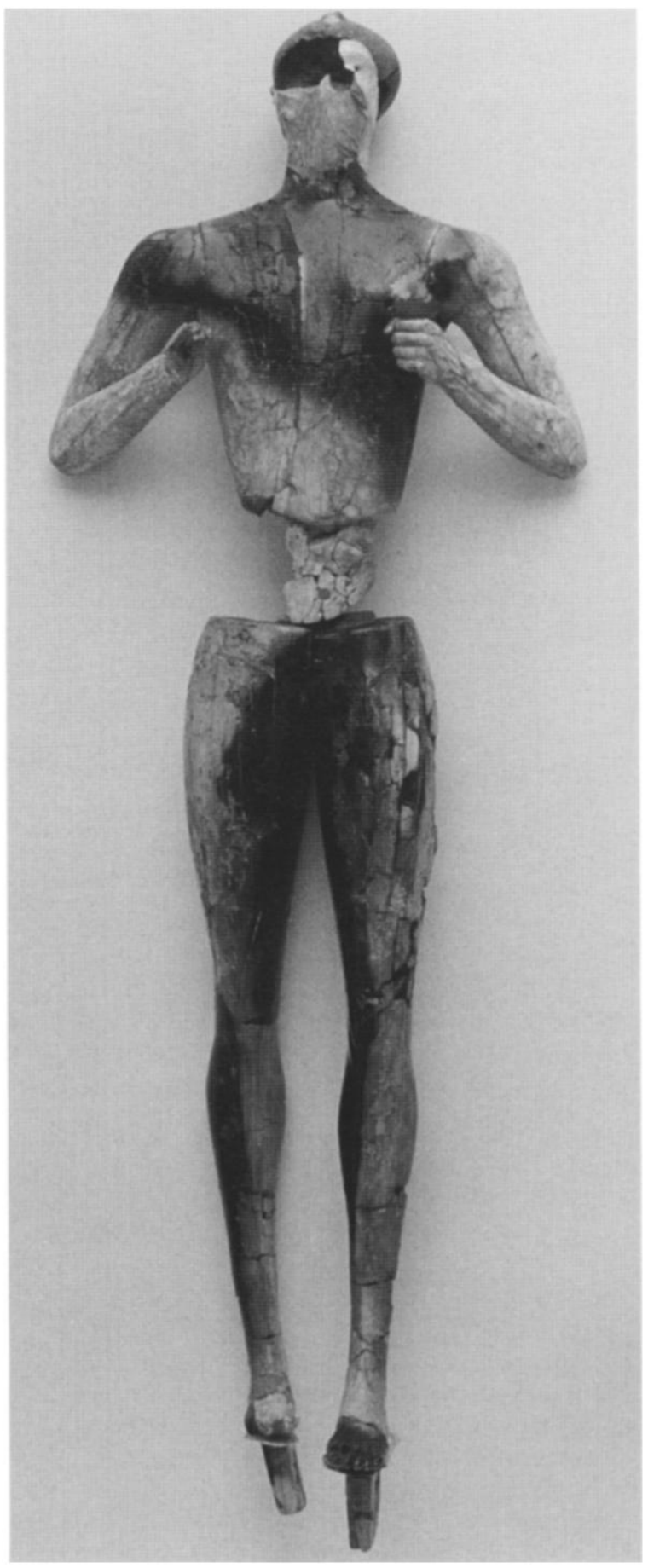

Fig. 7. Ivory youth from Palaikastro. H. total figure as reconstructed, without tenons $49.9 \mathrm{~cm}$. (Courtesy L.H. Sackett and J.A. MacGillivray)

from a later context from the palace at Mycenae; it represents two women and a child. ${ }^{167}$ The Minoan court costumes that the two women wear are well understood by the artist and the patterns, including a scale motif and a net pattern, suggest a date in LM
IA, certainly no later than LM II. ${ }^{168}$ The child, moreover, is probably a girl since it wears a robe, whereas small boys in Aegean art are usually shown nude. ${ }^{169}$

Frescoes. Simple painted plaster was in use already in EM II, and wall and floor paintings with abstract patterns were produced in MM times. It is not until the Neopalatial period, however, that we have our first evidence for figural frescoes, a development in which Knossos again took the lead. ${ }^{170}$ Wall surfaces were painted in three main areas: major panels flanked by a frieze at the top of the wall and by a dado at the bottom painted solid or with ornamental patterns (often veining); ceilings and floors also afforded areas for decoration. ${ }^{171}$

At Knossos, the palace gives evidence for several Neopalatial phases of figural wall painting. ${ }^{172}$ Early Neopalatial compositions include the earliest figural fresco, the Saffron Gatherer, and the Ladies in Blue and the Lady in Red. Later Neopalatial frescoes include (in LM IA) the Grandstand and Sacred Grove and Dance. If these frescoes have been correctly restored by Cameron as the decoration of a single room in the palace, we seem to have depictions of ceremonies taking place in the central and west courts,

${ }^{167}$ Poursat, Catalogue (supra n. 153) 20-21 no. 49, pl. IV. Hood (supra n. 157) 124-26, 125 fig. 114: "probably LH III A," but Hood notes (124) that the Triad shows "all the grace and attention to detail characteristic of Cretan figurines of the best period before ca. 1450" (i.e., before the end of LM IB).

${ }^{168} \mathrm{E}$. Barber has informed us (personal communication) that on the basis of dress patterns she thinks the Triad is unlikely to be later than LH II. Scale patterns on costumes in Neopalatial frescoes from Knossos (PM I, 545 fig. 397; II.2, 731 fig. 457; III, 297 fig. 194), and on a ship cabin fresco (LM IA) from the West House at Akrotiri: Doumas pls. 55, 58. Net pattern on costumes in the Priestess fresco from West House room 4 at Akrotiri: Immerwahr pl. 21; Doumas pls. 24-25; cf. the acrobat on the MM II gold repoussé sword guard from Mallia, in P. Darcque and J.C. Poursat eds., Liconographie minoenne (Paris 1985) 36 fig. 1.

${ }^{169}$ Ivory figurines from Palaikastro: PM III, 446 fig. 310a-b. Attendants in the fresco from Xeste 3, Akrotiri: Doumas pls. 109, 111.

${ }^{170}$ M. Cameron, A General Study of Minoan Frescoes with Particular Reference to Unpublished Wall Paintings from Knossos (Diss. Newcastle-uponTyne 1974), in preparation for publication by L. Morgan. New material: patterned fresco fragments from Mallia (LM IA; AR 37 [1991] 73), spiral relief fragments from Zakros, House $\Delta \alpha(A R 36$ [1990] 73).

${ }_{171}$ Ceilings: Immerwahr Kn no. 38. Floors: Hirsch (supra n. 80 ).

172 We follow primarily Immerwahr; C.F. Hawke-Smith, “The Knossos Frescoes: A Revised Chronology," BSA 71 (1976) 65-76 gives an alternative and detailed chronology. 
respectively. ${ }^{173}$ Unusually for Minoan art, these scenes include both men and women, though in each case some women are singled out as more important than the other figures in terms of their size, costume, hairstyle, and placement within the scene. These paintings thus are important evidence for the exceptional role of women in Minoan society. Outside the palace, nature scenes involving blue monkeys and other animals decorated the walls of the House of the Frescoes (LM IA). In the area of the Stratigraphic Museum, a fresco with a repeating frieze of floral garlands may date to LM IB. ${ }^{174}$ In general, Neopalatial frescoes tended toward figures in lithe and supple movements in miniature, busy scenes, painted with a polychrome palette.

The "glyptic revolution" in sealstones may have influenced the creation of relief fresco as well, and developments in media like terracotta appliqués and molded faience plaques (for both, see below) may have played a role; the creators of relief frescoes substituted plaster for clay, expanded the scale, and added paint. The earliest-known relief fresco frag. ment, of MM II date from Knossos, lacks human figures, ${ }^{175}$ but by LM I, humans, animals, and vegetation were being attempted, along with geometric motifs.

Relief frescoes emphasize the anatomy of the human body, ${ }^{176}$ with muscles, veins, and tendons all stretched and active (cf. fig. 7). Faces, by contrast, are painted flat. Men are wasp-waisted and muscular; they wear breechcloths with codpieces but are otherwise nude. Women are usually clothed in brightly colored and patterned robes with aprons tied around the waist, but their costume exposes the

\footnotetext{
${ }^{173}$ Immerwahr $173 \mathrm{Kn}$ nos. 15-16, pls. 23-24; E. Davis, "The Knossos Miniature Frescoes and the Function of the Central Courts," in Palaces 157-61; cf. N. Marinatos, "Public Festivals in the West Courts of the Palaces," in Palaces 135-42. For a reconstruction of the room, see M.A.S. Cameron, "The 'Palatial' Thematic System in the Knossos Murals," in Palaces 321-25, 327 fig. 11; R. Hägg, "Pictorial Programmes in Minoan Palaces and Villas," in Darcque and Poursat (supra n. 168) 209-17.

174 M.A.S. Cameron, "Unpublished Paintings from the 'House of the Frescoes' at Knossos," BSA 63 (1968) 1-31. P. Warren, "The Fresco of the Garlands from Knossos," in Darcque and Poursat (supra n. 168) 187-207; for additions, see Warren, Minoan Religion as Ritual Action (Göteborg 1988) 24-27.

175 Kaiser (supra n. 133) 286.

$176 \mathrm{~J}$. Coulomb, “À propos de l'art plastique minoen: Données anatomiques et iconométriques," $R A$ 1978, 205-26.

177 M.E. Caskey, Keos II: The Temple at Ayia Irini, Pt. I: The Statues (Princeton 1986); Caskey, in Sanctuaries 127-35.

178 S.D. Indelicato, "Were Cretan Girls Playing at Bull-
}

breasts, which were sometimes built up on conical cups embedded in the wall (the same technique used in the contemporary large terracotta figurines from Kea). ${ }^{177}$

The Egyptian and Near Eastern convention of painting females white and males red is also seen in Minoan fresco; white-painted females leapt bulls as did red-painted males, and they even wore the same costume, high shoes, and wristbands. Some scholars dispute that the color convention holds in this case, ${ }^{178}$ although this seems to be needlessly creating a problem: there is no reason why athletic young women could not have engaged in bullleaping. The well-known and frequently reproduced Priest-King from the south entrance corridor at Knossos is problematic in its iconography and skin color, because it was reconstructed from the fragments of several figures that may not belong together. ${ }^{179}$ The cap with floral ornaments and plume, for example, should belong to a sphinx or a woman dressed like the small faience Snake Handler.

Among the Cretan palaces, relief frescoes with human figures are a hallmark of Knossos alone. Images of bulls and male and female bull-leapers in relief dominated both sides of the north entrance passage. ${ }^{180}$ Sophisticated relief frescoes adorned the Great East Hall located on the edge of the central court opposite the throne room. ${ }^{181}$ Here, the relief decoration was probably renewed several times during the Neopalatial era. These phases are now difficult to distinguish, but the pictorial programs included bulls, athletic youths (bull-leapers or combatants), and important women. There are also leashed griffins, but these were probably not tied

Leaping?" Cretan Studies 1 (1988) 39-47; N. Marinatos, "The Bull as an Adversary: Some Observations on Bull-Hunting

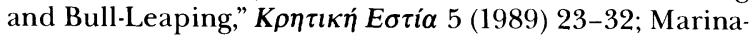
tos, "Formalism and Gender Roles: A Comparison of Minoan and Egyptian Art," in Politeia 577-85.

${ }^{179}$ PM II.2, col. frontispiece pl. XIV, 780 fig. 508 (torso), 773 fig. 504a (plume), 776 fig. 504b (headdress), 782 fig. 510 (lower leg), 784 fig. 511 (upper thigh and backflap), 774-86; J. Coulomb, "Le 'Prince aux Lis' de Knossos reconsideré," $B C H 103$ (1979) 29-50; W.D. Niemeier, "The 'Priest King' Fresco from Knossos: A New Reconstruction and Interpretation," in French and Wardle (supra n. 36) 235-44; E. Davis, "Art and Politics in the Aegean: The Missing Ruler," in Rehak (supra n. 39) 11-21; M.C. Shaw, "The 'Priest-King' from Knossos: Man, Woman, King, or Someone Else?" 8th CretCong (forthcoming).

${ }^{180}$ PM III, 158-77; PM IV.1, 11-18; L. Palmer, "Knossos: The High Relief Frescoes," in Forschungen und Funde (Innsbruck 1980) 325-34.

${ }^{181} P M$ III, 497-518; Kaiser (supra n. 133) 277-82. 
to columns, as Evans thought. Another fragment, identified by Kaiser, shows a figure wearing a "hide skirt," the same garment that appears in the Final Palatial Procession Fresco from the west entrance passage, discussed below. If this identification is correct, we may have links between the Procession Fresco and the procession's ultimate destination in the Great East Hall. The hall also included flat frescoes of lifesized women in elaborate costumes and jewelry, the Ladies in Blue and Lady in Red. ${ }^{182}$

Toward the end of the Neopalatial period, some nonpalatial buildings were decorated with relief frescoes of elaborately dressed women. At Pseira, a small house or town shrine was decorated with two women in relief. Fragments of another relief depicting a woman were found at Palaikastro, her clothing decorated with crocuses like the Thera goddess and the faience robes from the Knossos Temple Repositories. Other relief frescoes without human figures have been identified at Ayia Triada, Zakros (the palace and Houses $\Delta \alpha$ and $N$ ), and several other sites, including at least one in the Argolid. ${ }^{183}$

Plaster or terracotta offering tables, circular in shape and resting on three stubby feet, were often painted in the fresco technique, and since they show no signs of burning they were evidently not portable hearths. ${ }^{184}$ Some $40-50$ of these tables were stockpiled in the villa at Nirou Chani; approximately 30 others were stored in the palatial building at Archanes Tourkogeitonia. The painting is often impressive; one found recently at Palaikastro is decorated with narcissus flowers. In this context, it may be convenient to add the large stucco horns of consecration: two come from Archanes Tourkogeitonia, and two more were found in the Knossos palace, one near the Great East Hall, and the other at the northwest corner of the central court, near the throne room complex. ${ }^{185}$

Ceramics. Our knowledge of painted pottery at the beginning of the Neopalatial period is uneven. Developments in West Crete are largely unknown,

${ }^{182}$ Kaiser (supra n. 133) 281-82, pl. 50; M.A.S. Cameron, "The Lady in Red," Archaeology 24 (1971) 35-43.

18:3 Pseira: M.C. Shaw, "Aegean Sponsors and Artists," in Techne 481-504; Betancourt and Davaras, in Hesperia (supra n. 34) 215-19. Palaikastro: Bosanquet and Dawkins (supra n. 50) 148 and fig. 130. Ayia Triada: Halbherr et al. (supra n. 31) 89 fig. 55; Kaiser (supra n. 133) 304; Cameron (supra n. 170) 474. Zakros: $A R 22$ (1976) 31; AR 38 (1992) 64. Prassa: Cameron (supra n. 170) 402. The Argolid (Mycenae or Tiryns): 1) (now lost?) Immerwahr 194, MY additional no. 1; $A A$ 1923, fig. 3; 2) (a second piece) Kaiser (supra n. 133) 306, fig. 473, pl. 26; U. Jantzen, Führer durch Tiryns (Athens 1975) figs. $35-36$. while in East Crete the earlier light-on-dark style continues until LM I styles supersede it. ${ }^{186}$ In Central Crete, a simpler, less colorful style supplants the earlier Kamares ware. On the best pottery, polychrome motifs on a dark background are repeated in zones, and the standardized high quality of the ware probably means that only a few workshops are producing it, though in large enough amounts to be exported to the Cyclades. Utilitarian pottery, instead, was produced in fewer but more specialized shapes than before. A new ware, with a lustrous dark paint on a light background, is found mainly at Knossos. Patterns include tortoise-shell ripple and thick retorted spirals. Unpainted conical cups, the drinking vessel of the period, are ubiquitous.

Although light-on-dark painted pottery continues strongly into LM I, the beginning of the LM period is heralded by the widespread appearance of new dark-on-light wares. Some vases combine the two painting schemes, like a conical rhyton from Gournia decorated with a band of antithetic quirks in light-on-dark and spirals in dark-on-light. ${ }^{187}$ Better kilns and firing techniques produced fine, hard wares. A Floral Style and fabrics painted with finer tortoiseshell ripples appear to come from Knossos, though toward the end of LM IA local workshops elsewhere imitate these. At Kommos, for instance, light-on-dark pottery and high-quality utilitarian ware are made in the kiln associated with Building $\mathrm{T}$. By the end of LM IA, tortoise-shell ripple has virtually disappeared and dark-on-light pottery has increased in importance. The shape and size of conical cups throughout Central Crete become standardized, sug. gesting a conventional capacity of about $61 \mathrm{~g}$.

LM IB pottery is complicated. Two main classes have been distinguished: the Standard Tradition and the Special Palatial Tradition. The former represents a continuity from LM IA and a slow development. Motifs are often simplified and rendered quickly. Two major classes have been distinguished, the plain style and the polychrome style with added red and

\footnotetext{
${ }^{184}$ Knossos: PM II.1, 302 fig. 175; IV.1, 180 fig. 142. Ar. chanes: Archanes 38, col. fig. 21. Palaikastro: AR 37 (1991) 75. Nirou Chani: Xanthoudides (supra n. 52). Cf. N. Polychronakou-Sgouritsa, ArchEph 1982, 21-33.

185 Archanes: Archanes 38, 40 col. fig. 21. Knossos: PM III, 19 fig. 9: plan, and 524 fig. 367.

${ }^{186}$ Betancourt (supra n. 4). A.M.P.A. Van de Moortel, The Transition from the Protopalatial to the Neopalatial Society in South-Central Crete: A Ceramic Perspective (Diss. Bryn Mawr College 1997). We are grateful to the author for the opportunity to read and cite sections of her dissertation.

${ }^{187}$ Betancourt (supra n. 4) fig. 100 B.
} 
white. The Special Palatial Tradition comprises a relatively small class but its preference for unusual shapes and elaborate decoration has given it great weight in the literature. The Special Palatial Tradition has been subdivided into a Plant Style related to the earlier Floral, an Abstract/Geometric Style, the famous Marine Style, and, by the end of LM IB, the Alternating Style. Since several of these styles may coexist on a single vase, ${ }^{188}$ it is likely that these elite wares were made in a limited number of workshops and by a few artisans. ${ }^{189}$ Because the distribution of these wares is uniform throughout the island, it is likely that the center of production was at Knossos, though there are local varieties in the south, some apparently coming from the kiln at Ayia Triada. By the end of LM IB even utilitarian wares are emulating the high quality of elite wares.

Many of the motifs popular in LM IB pottery imitate designs that were already popular in other media in LM IA or even earlier, suggesting that even the Special Palatial Tradition is following, rather than leading, artistic developments. For example, the running spiral and lozenge pattern occurs on silverware and as a textile pattern on the large faience Snake Handler (see below) before it appears on LM IB pottery; strings of crocus buds in garlands or as necklace pendants in frescoes predate their representation on Floral Style vases.

Because of its modern aesthetic appeal, Marine Style pottery is often reproduced and discussed to the point of obscuring its highly specialized production and limited distribution. ${ }^{190}$ Mountjoy has sug. gested that vases in this style may have been produced primarily at Knossos and that they had a specialized use as ritual vessels on Crete. Scientific analyses of Marine Style pottery from outside Crete, however, show that much of it represents local Cycladic or

\footnotetext{
${ }^{188}$ E.g., Betancourt (supra n. 4) pl. $23 \mathrm{H}$.

${ }^{189}$ C. Floyd, "The Alternating Floral Style as Evidence for Pottery Workshops in East Crete during the Protopalatial Period," in Techne 313-16. Olive Spray Group: M.R. Popham, "Late Minoan Pottery," BSA 62 (1967) 337-51, esp. 341; Banou (supra n. 34) 157-58. The Reed Painter, Arcading Group: Betancourt (supra n. 4) 145-46, pl. 21 A-C, fig. 22 E; J.N. Coldstream and G.L. Huxley, Kythera (London 1972) pl. 33; Banou (supra n. 34) 159. Attempts to recog. nize individual artists in other media have been criticized: J.F. Cherry, "Beazley in the Bronze Age? Reflections on Attribution Studies in Aegean Prehistory," in Eikon 123-44, and comments, 339-44.

${ }^{190}$ The LM IB Marine Style was apparently very special; at Pseira it was found in only one building, BQ: Banou (supra n. 34) 145. See P.P. Betancourt, Archaeology 30 (1977) 38-43; Betancourt, AJA 81 (1977) 561; P.A. Mountjoy, BSA 69 (1974) 173-75; Mountjoy, BSA 69 (1974) 177-78; Mountjoy, $A A A 9$ (1976) 83-86; Mountjoy, AJA 81 (1977) 557-60; Mountjoy, BSA 79 (1984) 161-219; Mountjoy, in Darcque
}

mainland imitations. ${ }^{191}$ Thus, pot painters may be traveling more often than their wares, influencing the development of LH I mainland Mycenaean pottery. 192

The influence of other media is apparent on much of the pottery. Some vases take their inspiration from fresco: the polychrome dolphins, rockwork, and sea. weed on a LM IA painted tripod-stand in Minoan style from Akrotiri, ${ }^{193}$ and the same elements on LM IB Marine Style vases compare favorably with fresco representations; and the garlands on LM IB pots resemble those suspended from the posts of ship cabins in the LM IA fresco from the West House at Akrotiri. ${ }^{194}$ Some vases reflect the influence of metalwork: the spiral and arcade pattern on LM IA metalware recurs as a painted pattern on LM IB pottery. ${ }^{195}$ Building $\mathrm{Z}$ at Zakros contained a pithos with a frieze of double axes in relief. ${ }^{196}$ Other vases imitate stonework: a pithos from Pseira has a seg. mented collar shaped like that encircling the neck and body of some stone rhyta, and at Kythera clay imitations of stone blossom bowls were made. ${ }^{197} \mathrm{We}$ should consider the possibility that artists were trained and worked in more than one medium with equal versatility. Another important aspect of the painted fine wares of the Neopalatial period is that pottery was often made in pairs or sets, like some of the stone vases discussed above. This seems to be particularly true of cup rhyta and conical and ovoid rhyta.

Archaeologists tend to focus on fine, decorated wares, but plain pottery was always the most abundant. Two common Minoan shapes in domestic pottery are the small conical cups, which were produced in the tens of thousands annually, and large storage pithoi. ${ }^{198}$ Because of their size and shape, conical cups were easy to make and served a multitude of

and Poursat (supra n. 168) 231-42. See also P.A. Mountjoy et al., BSA 73 (1978) 143-72; and T. Marketou, BSA 82 (1987) 165-70.

${ }^{191}$ Jones 444.

192 R.E. Jones and J.B. Rutter, "Resident Minoan Potters on the Greek Mainland?" Archaeometry 19 (1977) 211-19.

193 Doumas pls. 181-83.

${ }^{194}$ Cf. a handled jar from Pseira (CM pl. 84, lower left) with the ship cabin fresco from Akrotiri, West House: Dou. mas pls. $49-62$.

${ }_{195}$ Cf. a silver ewer from SG IV at Mycenae (Davis [supra n. 135] 149-55 no. 43, fig. 120) with cups from Archanes (Archanes 55 col. fig. 32).

${ }_{196}$ AR 38 (1992) 64; Prakt 1991, pl. $222 \alpha$.

${ }^{197}$ Pithos from Pseira: Banou (supra n. 34) 68, 230 fig. 15 (drawing); Betancourt (supra n. 4) pl. 8 H. Clay bowls from Kythera: $A R 10$ (1964) 25 and fig. 30.

198 C. Gillis, Minoan Conical Cups (SIMA 89, Göteborg 1990), rev. by P. Warren, JHS 113 (1993) 219-20; M.H. Wiener, "Crete and the Cyclades in LM I: The Tale of the Conical 
purposes. In a house at Knossos, dozens of conical cups were inverted for stability and to keep the dust out, and placed on the floor of a pillar basement, while at Mochlos they were used as lamps in another basement pillar room. ${ }^{199}$

Pithoi were equally important and were made in quantity. These were probably built up with coils of clay on a thick disk base. Despite their large size, they were transported considerable distances; Cretan pithoi have been found in Cyprus and Sardinia. ${ }^{200}$ Similar pithoi are still being manufactured today in the Cretan village of Thrapsano, affording the ar. chaeologist modern parallels for manufacture and distribution. Since several of the ancient examples were inscribed in Linear A before they were fired (see below), some potters may have been literate or scribes intervened in the potting process.

Textiles. Textiles have not survived well, and their study is made more difficult by their scant mention in the Linear A texts. ${ }^{201}$ The discovery of spindle whorls and loomweights at many sites, however, and the depiction of textiles in paintings make it possible to reconstruct some aspects of the craft. The Minoans made use of the warp-weighted loom, and were ex-

Cups," in Thalassocracy 17-26. Pithoi: Begg passim, esp. 91-93; C. Doumas and A.G. Constantinides, "Pithoi, Size and Symbols," TAW III.1, 41-44; Jones 844-47; H. Blitzer,

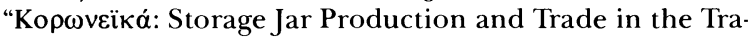
ditional Aegean," Hesperia 59 (1990) 675-711.

${ }_{199}$ PM II.2, 548 fig. 348; Begg 178; Soles and Davaras 1996 (supra n. 33) 190.

${ }^{200}$ R.E. Jones and P. Day, "Aegean-type Pottery on Sardinia," in M.S. Balmuth ed., Studies in Sardinian Archaeology III (Oxford 1987) 263.

${ }^{201}$ Studies by E.J.W. Barber include Prehistoric Textiles (Princeton 1991); "The Peplos of Athena," in J. Neils ed., Goddess and Polis (Princeton 1992) 103-17; Women's Work (London 1994); AJA 99 (1995) 303 (abstract); and "Minoan Women and the Challenges of Weaving for Home, Trade, and Shrine," in Techne 515-19.

$\mathrm{AB}$ sign 54, presumably the Linear A equivalent to $\mathrm{B}$ * 159 TELA, functions as an ideogram on only three tablets: HT 16, 20, 27 (GORILA 1, 32-33, 36-37, 50-51).

${ }^{202}$ Little is known about the dyes, except purple: D. Reese, "Palaikastro Shells and Bronze Age Purple-Dye Production in the Mediterranean Basin," BSA 82 (1987) 201-206. See also J.L. Davis, "Cultural Innovation and the Minoan Thalassocracy at Ayia Irini," in Thalassocracy 159-65, esp. 161-63 on technology.

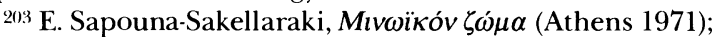
G. Lyberopoulou, Le costume égéen (Diss. Université de Paris

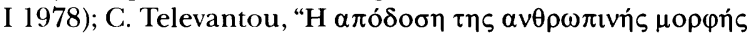

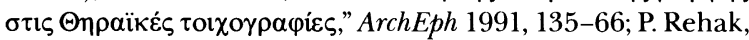
"Aegean Breechcloths, Kilts, and the Keftiu Paintings," AJA 100 (1996) 35-51.

${ }^{204}$ N.H. Gale, "Lead and Silver Sources for Bronze Age Crete," 5th CretCong (1985) 365-72; Gale, "The Provenance for Metals for Early Bronze Age Crete," 6th CretCong A1 (1990) 299-316; H.S. Georgiou, The Late Minoan I Destruc- pert weavers of dyed wool and probably of linen. ${ }^{202}$ Fresco scraps with textile patterns from the Northwest Fresco Heap at Knossos augment details of costume in the other frescoes, as do the faience votive dresses and three-dimensional figurines from the Temple Repositories. Based on frescoes, there have been several convincing attempts at reconstructing costume. ${ }^{203}$

Metalwork. Crete is relatively poor in metals, and most of its needs must have been supplied from outside the island. ${ }^{204}$ Well before the Neopalatial period, Crete was obtaining silver and lead from Cy. cladic sources, and gold may have been supplied in small quantities from Egypt or Syria. Bulk shipments of raw copper did not begin until the Late Bronze Age, and all signs indicate that Crete took an early and important lead in this trade. ${ }^{205}$ Copper oxhide ingots first appear on Crete in LM I at Tylissos, Ayia Triada, Zakros, Gournia, Kato Syme, and possibly Kommos; ${ }^{206}$ their weights center on $29 \mathrm{~kg}$, a Minoan talent. Later, in the 15th century, Egyptian tombs from the time of Hatshepsut and Tuthmosis III show men carrying oxhide ingots. The manufacture of bronze, however, demanded tin as well as copper,

tion of Crete (Los Angeles 1979).

${ }^{205}$ J.D. Muhly, R. Maddin, and T. Stech, "Cyprus, Crete and Sardinia: Copper Ox-Hide Ingots and the Bronze Age Metals Trade," RDAC 1988, 281-98; M.H. Wiener, "The Na ture and Control of Minoan Foreign Trade," in Gale 1991 (supra n. 12) 325-50.

${ }^{206}$ H.G. Buchholz, "Keftiubaren und Erzhandel im zweiten vorchristlichen Jahrtausend," PZ 37 (1959) 1-40; Muhly et al. (supra n. 205); J.D. Muhly, "The Crisis Years in the Mediterranean World," in W.A. Ward and M.S. Joukowsky, The Crisis Years (Dubuque 1992) 10-26, esp. 18: the ka-kona-wi-jo of Pylos tablet Jn 829 is "ship copper," i.e., "ingots." Copper ingots from Neopalatial (LM IB) sites (Georgiou [supra n. 204] gives inventory numbers, sizes, weights, and inscribed marks): 1 ingot from Tylissos (J. Hazzidakis, ArchEph 1912, 220-22, fig. 31; weight $26.5 \mathrm{~kg}$ ); 19 ingots in Building $\mathrm{A}$ at Ayia Triada (Halbherr et al. [supra n. 31] 123 fig. 85); 1 ingot fragment from Kato Syme; 4 ingot fragments from Gournia (P.P. Betancourt et al., MASCAJ 1 [1978] 7-8); 6 ingots from Zakros (N. Platon, in V. Karageorghis ed., Acts of the International Archaeological Symposium "The Rela. tions between Cyprus and Crete, ca. 2000-500 B.C." [Nicosia 1979] 101-10; Zakros 116-20, fig. 117; weights 29-30 kg); and 2 Cypriot copper ingots from Kommos, "almost certainly LM I in date" (L.V. Watrous, Kommos III, 172; the in gots: H. Blitzer in Kommos I.1, 501 nos. M2-M3), though Shaw (Kommos I.2, 398-99, n. 6) infers a LM III date from their findspot. Whole or fragmentary ingots have also been found at Chania, Palaikastro, Juktas, and Kophinas $(\mathrm{BCH}$ 118 [1994] 822). Four other ingot fragments from Kommos may date as late as LM IIIA2 (Blitzer, in Kommos I, 501 nos. M1 and M4-6); these are also metallurgically consis tent with a Cypriot origin (Muhly et al. [supra n. 205] 283-84). 
in ratios of approximately 1:10, and a variety of sources for both metals have been postulated and are still being debated. Some of the copper from Crete has been tested but only the ingots from Kommos are of Cypriot copper and most of these, if not all, are Final Palatial. Other, Neopalatial ingots from Crete that have been tested are not Cypriot, though Cyprus was a major producer of this metal then and later in the Late Bronze Age. The sources for tin are probably located farther east. ${ }^{207}$

Since bronze was inherently valuable, it was continually melted down and reworked. ${ }^{208}$ At Mochlos, several foundry hoards included ingots, ingot fragments, and broken tools that could represent scrap metal. ${ }^{209}$ A large amount of scrap bronze was stored in the Arkalochori Cave, perhaps under religious auspices since the cave was used to house dedications such as bronze swords, along with bronze, gold, and silver double axes. The bronzes from the cave probably constitute the largest deposit of metal found anywhere in the Mediterranean. ${ }^{210}$ Smaller amounts of bronze have been found at the sanctuaries at Kato Syme and on Juktas and Kophinas.

Lead and bronze were used for manufacturing small figurines depicting men, women, at least one child, and several agrimia. ${ }^{211}$ Many of the anthropomorphic figurines are identifiable as men or women on the basis of anatomy, but a large number are of

207 The ingots from Ayia Triada, Gournia, and Kato Syme are metallurgically similar and are not of Cypriot copper: N.H. Gale and Z.A. Stos-Gale, "Oxhide Copper Ingots in Crete and Cyprus and the Bronze Age Metals Trade," BSA 81 (1986) 81-100; Gale and Stos-Gale, "Recent Evidence for a Possible Bronze Age Metal Trade between Sardinia and the Aegean," in French and Wardle (supra n. 36) 349-84. The copper ingots from Ayia Irini, Kea (LM I context) are consistent with a Cypriot source, as are the ingots from the Cape Gelidonya wreck (early 13 th century): A.B. Knapp, "Cyprus, Crete and Copper: A Comment on Catling's Paradox," $R D A C$ 1990, 55-63, esp. 58. See too P. Budd et al., "Lead Isotope Analysis and Oxhide Ingots," JMA 8 (1995) 70-75; Muhly (supra n. 12); E. Pernicka, "Crisis and Catharsis in Lead Isotope Analysis?" JMA 8 (1995) 59-64. The mid-14th century Amarna tablets mention that the King of Alashiya was sending copper (presumably Cypriot if Alashiya is Cyprus) to Egypt. T.S. Wheeler, "The Ancient Tin Trade in the Eastern Mediterranean and Near East," TUAS 2 (1977) 23-26; E. Pernicka et al., JMA 5 (1992) 91-98; K.A. Yener and P.B. Vandiver, "Tin Processing at Göltepe," AJA 97 (1993) 207-38; J.D. Muhly, "Early Bronze Age Tin and the Taurus," $A J A 97$ (1993) 239-53; and Yener and Vandiver, AJA 97 (1993) 255-64 (reply); W.E. Sharp and S.K. Mittwede, Geoarchaeology 10 (1995) 139-42; E. Kaptan, "Tin and Ancient Tin Mining in Turkey," Anatolica 21 (1995) 197-203.

${ }^{208}$ P. Budd et al., "Oxhide Ingots, Recycling and the Mediterranean Metals Trade," JMA 8 (1995) 1-32, with com- indeterminate sex. Of the male figurines, many wear the breechcloth with rigid codpiece and have long hair like the individuals on stone relief rhyta; females usually wear a flounced skirt and have long hair. Some figurine poses are gender-specific. Male figures often stand with one fist clenched at the forehead, the other arm held straight at the side, while women almost never assume this pose. ${ }^{212}$

Metal figurines were often dedicated at peak sanctuaries or in caves, presumably as votive offerings. A large number have been reported from the Minoan peak sanctuary on Kythera. ${ }^{213}$ A group of miniature bronze "wigs" found at Knossos may have been used to complete figurines in another material. ${ }^{214} \mathrm{~A}$ bull and leaper group said to be from Rethymnon, currently in the British Museum, is unique. ${ }^{215}$

Bronze was also used for weapons. ${ }^{216}$ Type A Minoan swords were the finest in the Aegean, and they probably served as the ancestors to the subsequent sword types. Type A swords have been found in the palaces of Mallia and Zakros, and several fine blades were dedicated in the cave at Arkalochori. Before the end of the Neopalatial period, type B swords had been introduced on the mainland, though opinions differ over whether these were produced at Knossos or at Mycenae under Minoan influence. ${ }^{217}$ Ornamented weapons first appear in the Protopalatial

ments by N.H. Gale and Z.A. Stos-Gale (33-41), M. Hall (42-44), and E.V. Sayre, K.A. Yener, and E.C. Joel (45-53).

${ }^{209}$ Soles and Davaras 1996 (supra n. 33).

${ }^{210}$ E.P. Blegen, AJA 39 (1935) 134-36; S. Marinatos, Prakt 1935, 212-20; A.B. Knapp, J.D. Muhly, and P. Muhly, "To Hoard Is Human," RDAC 1988, 251.

${ }^{211}$ E. Sapouna-Sakellaraki, Die bronzenen Menschenfiguren auf Kreta und in der Ägäis (Stuttgart 1995); C. Verlinden, Les statuettes anthropomorphes crétoises (Providence 1984); Verlinden, "Réflexions sur la fonction et la production des figurines anthropomorphes minoens en bronze," OpAth 17 (1988) 183-90. Agrimia from Ayia Triada: Halbherr et al. (supra n. 31) 126 fig. 87.

${ }^{212}$ M. Lee, AJA 100 (1996) 366 (abstract).

${ }^{213}$ I.A. Sakellarakis, "Minoan Religious Influence in the Aegean," BSA 91 (1996) 81-99.

${ }^{214}$ R. Hägg, “The Bronze Hair Locks from Knossos,” $A A$ $1983,543-49$.

${ }^{215}$ PM II.2, 651 fig. 416; J.G. Younger, "Bronze Age Representations of Aegean Bull-Leaping," AJA 80 (1976) 125-37, esp. 127-28, no. I.6, pl. 20.3.

${ }^{216}$ N.K. Sandars, "The First Aegean Swords and Their Ancestry," AJA 65 (1961) 17-29; Sandars, "Later Aegean Bronze Swords," AJA 67 (1963) 117-53; O. Höckmann, "Lanze und Speer in spätminoischen und mykenischen Griechenland," JRGZM 27 (1980) 13-158.

217 S. Hood, "Shaft Grave Swords: Mycenaean or Minoan?" 4th CretCong, 233-42. 
period, ${ }^{218}$ perhaps under influence from Syria and Egypt. In the Neopalatial period, Minoan smiths may have been responsible for the decorated weapons found mostly on the mainland.

Examples of practical metal tools also survive: double axes, saws, chisels, and hammers. ${ }^{219}$ A small number of double axes are decorated with incised motifs: a plumed helmet on each side, a frontal bucranium, and a butterfly. ${ }^{220}$ The most elaborate example, an ax from Vorou, has a figure-eight shield flanked by sacral knots on one side, and on the other a single "sacral robe" flanked possibly by quivers;"221 all these emblems have suspension loops at the top. Shields with similar suspension loops are sometimes painted as a repeating frieze on LM IB pottery, and these may be ancestral to the frescoed shield friezes of LM/LH III date found at several Aegean sites. A bronze spearhead from Anemospilia, dating to the beginning of the Neopalatial period, is engraved with a frontal boar's head. ${ }^{222}$ Similar lanceheads and spearheads come from later tombs in the New Hospital and Ayios Ioannes cemeteries.

Sheets of gold, silver, and bronze were also used for nonfunctional double axes, some of which have elaborate surface decoration: two from the Arkalochori Cave are inscribed, and several huge bronze examples were found in the villa at Nirou Chani. ${ }^{223}$ Two elaborately engraved, sheet bronze double axes with traces of gilding come from the Zakros palace. A few Neopalatial representations show these axes

218 Mallia: dagger from Quartier Mu (Detournay et al. [supra n. 99] col. frontispiece, 147-49 no. 219, figs. 21920); and three swords from the west wing, including one decorated with the figure of an acrobat (O. Pelon, in Darcque and Poursat [supra n. 168] 35-39, 36 fig. 1). Cf. the Mitsotakis dagger: A. Xenaki-Sakellariou, $R A$ 1986, 235-44.

${ }^{219}$ Shaw (supra n. 68) 44-74; R.D.G. Evely, Minoan Crafts 1 (SIMA 92.1, Göteborg 1993) 2-141. Hammers: MantePlatonos (supra n. 145). Saws: B.H. Wells, Expedition 16:4 (1974) 2-8.

${ }^{220} \mathrm{P}$. Cassola Guida, Le armi difensive micenei nella figurazione (Rome 1973) 163 no. 152, pl. XXVIII.3. Axes: H.G. Buchholz, Zur Herkunft der kretischen Doppelaxt (Munich 1959) 40 , pl. VIIa.

${ }_{221}$ C. Verlinden, "Nouvelle interprétation du décor incisé sur une double hache en bronze supposée provenir de Voros," in Darcque and Poursat (supra n. 168) 139-49; N. Marinatos, Minoan Sacrificial Ritual (Stockholm 1986) 56 and fig. 46; I. Kilian-Dirlmeier, "Remarks on the NonMilitary Function of Swords in the Mycenaean Argolid," in R. Hägg and G.C. Nordquist eds., Celebrations of Death and Divinity in the Bronze Age Argolid (Stockholm 1990) 160 and fig. $3 \mathrm{~b}$ (drawing).

${ }^{222}$ Archanes 151 col. fig. 130. being carried in processions or associated with bucrania, ${ }^{224}$ but no scene of sacrifice where the victim is trussed on the table includes a double ax.

Metalsmiths also made a variety of copper and sheet bronze vessels beginning in MM II. Their manufacture continued on into the Neopalatial period, when the complexity of shape and decoration increased. ${ }^{225}$ Some of these are strictly utilitarian, and were probably manufactured in large numbers. Many of the clay roundels found at Chania are incised with tripod cauldrons. ${ }^{26}$ A hoard of enormous bronze cauldrons was discovered at Tylissos, ${ }^{227}$ and the bronze handle of an even larger cauldron was found in the Zakros palace. Other sheet metal vessels are more elaborate, with handles and rims decorated in relief with shells, abstract designs, and even friezes of double axes. ${ }^{228}$ Many of these relief patterns are cast, and thus are more durable versions of the terracotta appliqués on pottery. Low open bowls or lavers with upswung handle were made of silver or bronze, often with relief decoration along the rim. Sometimes these and other metal vessels were manufactured to function together as pairs or sets, like examples found at Knossos and Mochlos. ${ }^{229}$

Apart from bronze, vessels were also made of gold and silver from early on, though very few pieces have survived from the Protopalatial period. ${ }^{230}$ Most precious metal vessels were "raised" by hammering a single sheet of malleable gold or silver to a desired shape and thinness. Since Crete is poor in silver and

${ }^{223}$ From Pinakiano, also in Linear A: PGC 59 no. 720. Chania: BCH 110 (1986) 755 fig. 162. Arkalochori, one in Linear A: M. Pope, BSA 51 (1956) 132-35; ArchEph 19531954, 64; one near the "Phaistos" syllabary: L. Godart, $I l$ disco di Festos (Florence 1993). Nirou Chani: Xanthoudides (supra n. 52). Zakros: Zakros 146 and reconstruction; $P G C$ 59 no. 722.

${ }^{224}$ CMS II.3, nos. 8 and 11.

${ }^{225}$ H. Matthäus, Die Bronzegefässe der kretisch-mykenischen Kultur (Munich 1980); Detournay et al. (supra n. 99) 71-88.

${ }^{226}$ Hallager II, roundels KH Wc 2008-25, incised with Linear A $* 409^{\mathrm{vas}}$ (no handles) and $* 411^{\mathrm{vas}}$ (horizontal handles).

${ }^{227}$ Hazzidakis (supra n. 206) 220, fig. 29; PM II.2, 569 fig. 355. Hazzidakis also gives the weights for the cauldrons: $52.564,24.360,15.700$, and $12.500 \mathrm{~kg}$.

${ }^{228}$ E.g., Zakros 147 fig.

${ }^{229}$ E.g., PM II.2, 637-44, figs. 402, 403, 407, 409a-b; Soles and Davaras 1996 (supra n. 33).

${ }^{230}$ E.g., deposit of silver vessels from the South House at Knossos: PM II.1, 387 and fig. 221. Part of a fluted clay vessel from a MM II context in Quartier Mu at Mallia may imitate metal: Detournay et al. (supra n. 99) 89 no. 120, 88 fig. 119. 
gold sources, the metals, and initially the techniques for creating plate, were probably imported from Syria. Few pieces of Neopalatial plate have been found on Crete, although those that come from early Final Palatial contexts are probably heirlooms, and many of those found on the mainland were probably made in Crete. ${ }^{231} \mathrm{~A}$ characteristic aspect of the silver vessels is that they use gold sparingly, often for accents. Some Minoan stone relief vessels, such as the Zakros Sanctuary Rhyton, however, seem to have been covered with gold foil originally.

Jewelry. Jewelry is beginning to receive the attention it deserves. ${ }^{232}$ Although many types of jewelry are depicted in fresco, few actual pieces have survived, yet these seem more individualized than $\mathrm{Fi}$ nal Palatial and mainland Mycenaean jewelry, which used a more restricted range of materials and was mostly mass-produced. Neopalatial jewelry builds on trends already established in earlier periods. ${ }^{233}$ In the Protopalatial and early Neopalatial periods, jewelry and other objects are imported from Syria or Egypt that employ new techniques (cloisonné, granulation, repoussé, and combinations of precious and semiprecious materials). ${ }^{234}$ Aegean artists may not have adopted these techniques immediately. The earliest demonstrably Minoan example of granulation occurs on a gold band that encloses a sard prism seal from the Poros Herakleion chamber tomb, 235 while the gold amygdaloid jewel from Pylos (CMS

231 Neopalatial Crete: Davis (supra n. 135) 102-109; Final Palatial Crete: Davis (supra n. 135) 109-17. Davis attributes the "quiet" Vapheio cup to a Minoan workshop, the "active" cup to a Mycenaean workshop; also see her "The Vapheio Cups: One Minoan and One Mycenaean?" ArtB 56 (1974) 472-87; cf. J. Hurwit, "The Dendra Octopus Cup and the Problem of Style in the Fifteenth Century Aegean," AJA 83 (1979) 413-26.

${ }^{232}$ M. Effinger, Minoischer Schmuck (Oxford 1996); R. Higgins, Greek and Roman Jewellery ${ }^{2}$ (Berkeley 1980); Younger

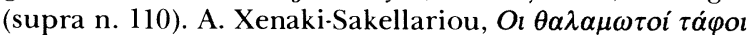

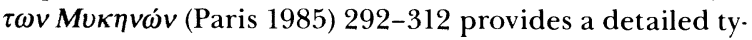
pology of beads from Mycenae.

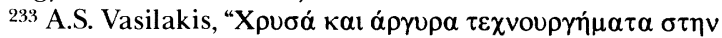

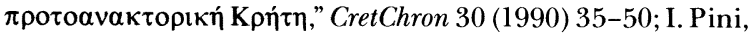
"Minoan and Mycenaean Decorated Gold Finger-Rings," in Techne 199 (abstract); Higgins (supra n. 232) 20-24.

${ }^{234}$ From the Poros Herakleion chamber tomb comes a ring with a circular cloisonné bezel (Metaxa-Muhly [supra n. 95] 90 no. 240, pl. 26), and two early pieces of jewelry carry granulation: a gold lion from Koumasa Tholos B (S. Xanthoudides, Vaulted Tombs of Mesara [London 1924] 29, pl. IV no. 386), and the "wasp" pendant from Mallia ( $P G C$ 108-109 no. 1296; E.F. Bloedow and C. Björk, "The Mallia Pendant," SMEA 27 [1989] 9-68). These three early pieces may not be Minoan in manufacture but Syrian, along with the pieces from the Aegina Treasure: C. Gates, "Iconography at the Crossroads: The Aegina Treasure," in Laffineur
I, no. 293) may be the earliest Aegean piece to employ cloisonné. Two rings from Sellopoulo tomb 4 (LM IIIA1) and a tomb at Kalyvia (LM IIIA1-2) carry a cloisonné bezel surrounded by granulation. ${ }^{236}$

While most Neopalatial gold jewelry takes simple shapes, ${ }^{237}$ especially lentoid, amygdaloid, teardrop, granular, and spherical beads, some items are figural. The early Neopalatial relief Jewel Fresco from Knossos depicts a man's hand holding one end of a necklace composed of beads in the shape of frontal male heads with pendant triple earrings. ${ }^{238}$ The Poros Herakleion tomb included a pair of moldmade gold foil ornaments with ducks against a backdrop of lily flowers, as well as beads in the shape of figure-eight shields. A gold fish-bead comes from the drain shaft in the east wing of the Knossos palace. ${ }^{239}$

Women's gold hair rings survive from Archanes Tholos $\mathrm{A}$ and the Mafeze tomb at Amnisos. Hair. pins, however, have also been found and these tend to be highly individualized. ${ }^{240}$ One pin found at Mavro Spelio was engraved with crocus blossoms on one side and a Linear A inscription on the other. A silver pin with a Linear A inscription was found in Tholos B at Archanes. Another silver pin found near the Royal Road has a gold finial in the shape of a human eye, a device that occurs as a floating element on some gold cult rings. ${ }^{241}$ A fresco from Akrotiri shows a woman wearing two hairpins, one like a myrtle or olive twig, the other with an iris finial.

(supra n. 31) 215-25. J. Weingarten, The Transformation of Egyptian Taweret into the Minoan Genius (SIMA 88, Partille 1991); Rehak and Younger (supra 153).

${ }^{235}$ Metaxa-Muhly (supra n. 95) 100 pl. 32 no. 302. The granulated bucrania earrings from the same tomb (pl. 26 nos. 238-39) are probably Cypriot: R. Laffineur, "Les pendants d'oreilles minoens en forme de bucrâne," 4th Cret. Cong I (1980) 281-96.

236 Sellopoulo: M.R. Popham and H.W. Catling, BSA 69 (1974) 195-257, esp. 219 fig. 14H, pl. 37g. Kalyvia: L. Savignoni, MonAnt 14 (1904) 500-666, esp. 546 fig. 53.

${ }^{237}$ Cf. necklaces from Ayia Triada (S. Alexiou, Guide to the Archaeological Museum in Herakleion [Herakleion 1969] 70) and Archanes Tholos A (Archanes 80-81, figs. 56-58).

${ }^{238}$ PM I, 525-27, 526 fig. 383; Immerwahr $172 \mathrm{Kn}$ no. 29. Cf. the frontal head of the "Master" on the pendant from the Aegina Treasure: Gates (supra n. 234) pl. XLIX.

${ }^{239}$ Metaxa-Muhly (supra n. 95) 90-91 nos. 241-45, pls. 27-28; PM III, 405, fig. 274.

${ }^{240}$ Younger (supra n. 110) 260. Mavrospelio: S. Alexiou, AAA 8(1975) 133-38; GORILA 4, KN Zf 31. Katsamba: Alexiou (supra n. 158) pl. 128. Archanes: Archanes 95, ARKH Zf 9 unpublished, and 131 fig. 109. Knossos: AR 3 (1957) 20; A.J. Evans, "The Prehistoric Tombs of Knossos," Archaeologia 59 (1905) 541 fig. 129, also published separately (London 1906) 151 fig. 129. Thera: Doumas pls. 100, 105, 106.

${ }^{241}$ E.g., the Isopata ring, CMS II.3, no. 51. 
Metal rings first appeared in MM II, reaching a high level of excellence in the Neopalatial era. These rings have been typed into seven classes with both elliptical and circular bezels (MM II). ${ }^{242}$ Their hoops are too small for them to have been worn on the fingers; instead, evidence from burials indicates they were probably suspended from necklaces or bracelets. ${ }^{243}$ Gold rings with oval bezels are well known for their cult scenes. ${ }^{244}$ They probably were first made in late MM III since their human figures display a well-modeled anatomy, and continued at least into LM I. How much later these cult rings continued is debated. Certainly the main type belongs primarily to LM I, but the number of them found in later contexts and reflected in Knossos sealings has led a few scholars to date them as late as LM IIIA1.

The religious scenes on rings consist of a few topoi: a frieze of sacred knots and/or figure-eight shields, griffins and sphinxes, women and griffins, and women at altars. ${ }^{245}$ The more elaborate rings, however, depict rituals involving one or more of the following elements: a man or woman at a baetyl; a man or woman touching, tugging, or plucking a tree; and a central woman apparently in movement. ${ }^{246}$

Glass for jewelry was introduced in the Neopalatial period. ${ }^{247}$ From a Poros Herakleion tomb (LM I) come ladle-shaped glass beads, a glass seal, and a cloisonné ring that had glass inserts. ${ }^{248}$ A fragment of a steatite mold for casting glass or gold jew. elry comes from the Kephala tholos at Knossos; its matrices produced beads or plaques in the shape of a crocus bud and a "sacral ivy" leaf, both of which

${ }^{242}$ J.G. Younger, "Seven Types of Ring Construction in the Greek Late Bronze Age," in Aux origines de l'Hellénisme (Paris 1984) 84-90; and the same seven types: A. XenakiSakellariou, "Techniques et évolution de la bague-cachet dans l'art crétomycénien," CMS Beiheft 3 (Berlin 1989) 323-38; Xenaki-Sakellariou, "To $\delta \alpha \chi \tau \nu \lambda i \delta$ - $\sigma \varphi \rho \alpha \gamma i \delta \alpha \sigma \tau \eta \nu$

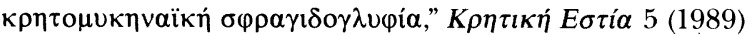
11-16; Younger (supra n. 104) 181-82. Early rings and ring impressions: P. Yule, Early Cretan Seals (Mainz 1981) 77, class 28d; I.A. Sakellarakis, "Matrizen zur Herstellung kretischmykenischer Siegelringe," CMS Beiheft 1 (Berlin 1981) 167-80; CMS II.3, no. 38; II.5, nos. 201, 202, 270, 304; V Suppl. 1A, nos. 45-46; VII, no. 68.

24.3 Younger (supra n. 111) 149-52.

${ }^{244}$ Most discussions of religion include the representations on rings; few studies, however, center on rings and their iconography: W.D. Niemeier, "Zur Ikonographie von Gottheiten und Adoranten in den Kultszenen auf minoischen und mykenischen Siegeln," CMS Beiheft 3 (Berlin 1989) 163-86; M. Wedde, "Pictorial Architecture," in Eikon 181-203.

${ }^{245}$ E.g., $C M S$ I, nos. 127, 128, 191, 218, and 410; II.3, nos. 15, 39, 56, 113; and V, no. 728; Archanes 93 fig. 68; ILN 26 March 1966, 32-33 fig. 8.

${ }^{246}$ E.g., CMS I, no. 126; and II.3, no. 114; Popham and were apparently popular forms of jewelry for women depicted in fresco ${ }^{249}$ and common motifs on LM IA-B pottery.

Faience. Related to glass is faience production, a technique imported from Syria or Egypt during MM II that demands a high level of technical expertise and a skillful control of firing temperatures to create quartz-glazed objects in subtle colors. Inlays and plaques are common, along with vessels, seashells, and three-dimensional figurines. ${ }^{250}$ Molds and unworked material from the Northwest Building at Knossos, and the south wing workshops in the Zakros palace, indicate that faience was probably made at just a few palatial sites.

Moldmade plaques of faience, probably for inlays, include a wide range of shapes at Knossos: house facades combined to create the Town Mosaic, depictions of animals suckling their young, models of women's dresses, some patterned with rockwork and crocus plants, and abstract and geometric inlays.

The faience figurines of women are well known. There are parts of at least three Snake Handlers from the Knossos Temple Repositories, not only the two usually illustrated. ${ }^{251}$ The skirt and hand of another faience figurine were found in the Zakros palace, and the breast of another woman came to light in the Royal Road South excavations at Knossos. Since this type of female figurine is unique, it is difficult to tell what they represent, although most scholars call them goddesses, priestesses, or votaries, and their snakes symbols of domestic or chthonic cult. ${ }^{252}$ Handling of snakes should be an attribute of the Pot-

Catling (supra n. 236) 217-19, fig. 14D and pl. 37a-b; and Archanes 79 fig. 54 .

${ }^{247}$ T.E. Haevernick, "Mykenisches Glas," JRGZM 7 (1960) 36-58, and "Mycenaean Glass," Archaeology 16 (1963) 190-93; I. Pini, "Spätbronzezeitliche ägäische Glassiegel," JRGZM 28 (1981) 48-81.

${ }^{248}$ Poros: Metaxa-Muhly (supra n. 95 ) 90 no. 240 and pl. 26, 91 no. 248 and fig. 22,100 no. 304 and pl. $33,188-89$. Knossos: Hutchinson (supra n. 92) 79-80 no. 17, pl. 12f; $P M$ IV.2, 963-64, col. pl. XXXIV.

${ }^{249}$ Immerwahr $172 \mathrm{Kn}$ no. 11; PM II.2, 679-82, fig. 430a.

${ }^{250}$ K.P. Foster, Aegean Faience of the Bronze Age (New Haven 1979); Foster, "Reconstructing Minoan Palatial Faience Workshops," in Palaces 287-92, and discussion 292; H. Waterhouse, "The Knossos “Town Mosaic' Reconsidered," Cretan Studies 4 (1994) 165-74; M. Panagiotaki, "Preliminary Technical Observations on Knossian Faience," OJA 14 (1995) 137-49. Mallia Quartier Mu (MM II): Detournay et al. (supra n. 99) 133 no. 183, 135 fig. 186. Knossos: PM I, 301-11, 471-90, 497 fig. 349, 506 and fig. 364, 510-12; CM pl. 71. Archanes Tourkogeitonia: AR 36 (1990) 71 .

${ }^{251}$ Knossos: $P M$ I, figs. 360-62, 503, 523 fig. 382; Foster 1979 (supra n. 250) 70-76, pls. 7-11; CM pls. XXIV-XXV; the Royal Road fragment is unpublished. Zakros: Zakros 218. 252 MMR2 311-16. 
nia Theron; in later Greek vase painting, however, women who handle snakes are maenads. The small Knossos Snake Handler with the flat cap also has a spotted feline mounted on it, probably a leopard, an animal that also has parallels in the depictions of later maenads.

Terracottas. Anthropomorphic and zoomorphic figurines of terracotta were already being made in EM times, and in the MM period they were commonly dedicated at peak sanctuaries. At most sites, male figures outnumber female, and bovids are also common. Some male figurines half a meter in height from Kophinas approach the size of small statues. ${ }^{253}$ A few Prepalatial and Protopalatial figurines may allude to the origin of bull sports. In the Neopalatial era, terracotta bull rhyta, some of them moldmade, were produced at several sites; occasionally the backs of the animals are painted with net patterns. ${ }^{254}$ One bull rhyton from Pseira has deliberately truncated horns, as if they had been sawn down.

Clay relief appliqués, presumably fashioned in molds, were also applied to vessels of clay beginning late in the Protopalatial period and continuing into the Neopalatial period.255 In the Protopalatial period such appliqués often took the form of marine shells and rockwork, but some figural appliqués exist as well, notably cups from Mallia with entire landscapes depicted, including palms and cats. The relief bull on a jar from Anemospilia (MM IIIA) foreshadows the relief bulls on the walls of the Knossos palace. Finally, terracotta versions of triton shells and bull's-head rhyta form counterparts to more elaborate examples in stone and faience. ${ }^{256}$ Other specialized terracottas such as architectural models, stands, and human feet are considered below under "Religion."

Furniture. Although very few pieces of actual furniture have survived, we assume that the Minoans were competent woodworkers. ${ }^{257}$ From Akrotiri

${ }^{253}$ BCH 118 (1994) 822; AR 42 (1996) 45; and ArchDelt 45 (1990) 429-30.

254 J.G. Younger, "Bronze Age Representations of Aegean Bull-Games, III," in Politeia 507-45, esp. the terracotta rhyta nos. 7-9 and 14-18. Net patterns: e.g., PGC 101 nos. 1220-22; PM II.1, 259 fig. 154b.

${ }^{255}$ Foster (supra n. 105); Detournay et al. (supra n. 99) 116-32; PM IV.1, 116-20 for discussion of relief shells on vases.

${ }^{256}$ J.L. Lloyd, "A Clay Triton Shell," OpAth 20 (1994) $75-88$.

257 J.G. Younger, "The Iconography of Rulership: A Conspectus," in Rehak (supra n. 39) 151-211, esp. 188-93; Krzyszkowska (supra n. 155).

${ }^{258}$ Beds: Thera IV, pls. 104-105; Metaxa-Muhly (supra n. 95) 149-64. Baskets, etc.: AR 41 (1995) 57. Stool: Thera come the plaster casts of several items, including beds, chests, and baskets; ${ }^{258}$ and a tomb at Poros Herakleion contained the remains of two cedar beds, the components of which had been secured by bronze staples. Wooden coffins ${ }^{259}$ are known as early as the Shaft Grave period on the mainland, though the earliest Minoan wooden coffins may date to LM II and other examples are known from LM IIIA graves. Stone furniture that may reflect wooden prototypes provides more evidence. ${ }^{260}$ The gypsum seat from the Knossos throne room includes a number of details in relief that derive from woodwork: the crockets on the legs, the curved strut at the front, the contoured seat, and the undulating profile of the back. Three less elaborate but related stone seats were found in the Knossos area: a low limestone seat from the service section of the throne room complex, a similar seat from Myristis near Anemospilia, and a backless stone seat from Katsamba. The gypsum or limestone benches with "triglyph" panels, found in many palaces and villas, may also imitate wooden examples.

The Palatial Prestige System and the Role of Knossos In Neopalatial Crete, local and imported raw materials, artisans and their labor, and finished products apparently were all controlled by the major palaces and villas. In these centers the objects would be manufactured and then distributed elsewhere, perhaps in exchange for other goods and services or as gifts and markers of status. ${ }^{261}$ Neopalatial art must have therefore reflected the contemporary value system of these centers, providing images which the elite in power used to promote itself. ${ }^{262}$

As in the Near East and Egypt, these display items consisted mostly of rich, miniature, and portable art objects. Many of these were stored and brought out when needed. ${ }^{263}$ In the west wing at Zakros, rooms

IV, pls. 102-103.

259 P. Muhly, "Furniture from the Shaft Graves," BSA 91 (1996) 197-211; R. Hägg and F. Sieurin, "On the Origin of the Wooden Coffin in Late Bronze Age Crete," BSA 77 (1982) 177-86.

260) Younger (supra n. 257) 188-93.

261 Kopcke (supra n. 35); Alexiou (supra n. 35); Wiener (supra n. 35); Clarke (supra n. 100). Cf. M. Mauss, The Gift: Forms and Functions of Exchange in Archaic Societies (London 1966); S.M. Pollock, The Symbolism of Prestige: An Archaeolog. ical Example from the Royal Cemetery of Ur (Diss. Univ. of Mich. igan 1983).

262 Moody (supra n. 35).

263 Storage areas could be small rooms, partitioned areas, mudbrick closets, built chests, and cists below floors. See Begg, passim. 
with clay storage cists existed in close proximity to the workshops where some of the objects stored must have been manufactured; ${ }^{264}$ both work and storage rooms, however, do not communicate with the supposed "shrine" nearby, but rather with the banqueting halls where the stone maces, rhyta, and chalices may actually have been displayed and used. In addition to a stone relief rhyton fragment showing men carrying stone ladles, ring impressions depict women and men carrying poles, double axes, fabrics, and vessels in procession. It is significant that, outside the peak sanctuaries, very few fixed areas for social or religious ritual have been identified for the Neopalatial era. Presumably, these portable objects were displayed in other formal settings, like courts and in processions.

These prestige objects are widely distributed. For instance, an ornamental stone mace, a stone rhyton, palatial pottery, and sealed documents impressed by gold look-alike rings (see below) were sent to the country house at Sklavokambos on the main route leading from Knossos to Mt. Ida; the villa at Pyrgos received imported Egyptian stone vases and a moldmade triton shell of pink faience; the court-centered building at Makriyialos obtained a stone chalice and Marine Style pottery; and, on stylistic grounds, $\mathrm{Pa}$ laikastro may have received its ivory youth and the Zakros palace its Sanctuary Rhyton from workshops at Knossos. Ayia Triada is particularly rich in prestige objects probably manufactured at Knossos: the Boxer Rhyton has scenes of bull sports and sinewy human figures that seem particularly Knossian.

These objects found scattered across the island suggest a system of exchange by which these centers are tied into a palatial prestige system that reflects a network not just of political ties to Knossos, but also of artistic techniques, iconography, and religious beliefs and symbolic practices, most of which seem to emanate from Knossos.

As a leader and innovator in artistic production, Knossos was surely the most important Neopalatial center in Crete. The central court and west court of the palace are the largest on Crete, and would have provided gathering spaces for hundreds of individuals at a single time. The west wing, with its long storage magazines lined with large pithoi, was the main supply center for the palace. ${ }^{265}$ The remainder

\footnotetext{
${ }^{264}$ Zakros 217-18, 218 fig. Stoneworking areas were located in rooms $\Pi$ upper floor, XIII upper floor, XXVI, and XLIII.

265 I. Begg, "Continuity in the West Wing at Knossos," in Palaces 179-84.

$266 \mathrm{~J}$. Driessen and C. Macdonald, "The Drainage System
}

of the west wing housed ceremonial rooms including the only undisputed throne room on Crete, pillar basements, and the so-called Temple Repositories. Over all these, an upper floor that Evans called the "piano nobile" has been reconstructed, the rooms of which were decorated with frescoes. Extensive terracing on the east side of the palace supported the Great East Hall at the level of the central court, and south of it the Grand Staircase led to the "Domestic Quarter," a misnomer since its stone drains and polythyra indicate ceremonial rather than living areas. ${ }^{266}$

Recently, several scholars have suggested that Neopalatial Knossos may have been most important as a ritual center. ${ }^{267}$ In support of this hypothesis are the lack of identifiable deposits of domestic pottery of Neopalatial date (although these are common in many of the houses outside the palace) and the presence of LM IA pottery choking the drains of the east wing. The Phaistos palace similarly shows few signs of actual human occupation in the final phase of the Neopalatial period.

Knossos is the only palace with both large-scale and miniature frescoes depicting the human form; the large-scale figures are sometimes executed in relief. As noted earlier, these frescoes emphasize important women, gatherings of women and men, phys ical combat among athletic youths, bull-leaping with adolescent youths and maidens as participants, and the architecture of palatial buildings and peak sanctuaries. Several of these topoi were also carved on gold rings carried by top administrators and on stone relief rhyta. The repetition of a few select images in a variety of media suggests that the Neopalatial elite wanted to project these images to the rest of the population. The pictorial programs of the major entrances to the palace deserve emphasis, since here stood bull and procession scenes that confronted all visitors to the complex.

These pictorial themes suggest that the palace had three important functions. First, it was a setting for ritual activities involving women and men, perhaps on a seasonal basis or according to a religious calendar. Second, the depiction of supernatural creatures like griffins or sphinxes may indicate that the palace was considered a liminal zone where the real and supernatural worlds intersected. Third,

in the Palace of Knossos," BSA 83 (1988) 235-58; Macdonald and Driessen, "The Storm Drains of the East Wing at Knos. sos," in Darcque and Treuil (supra n. 3) 141-46. There is no evidence for the flush toilets sometimes claimed to exist.

267 E.g., J. Soles, "The Functions of a Cosmological Center: Knossos in Palatial Crete," in Politeia 404-14. 
Knossos seems to have been a major center on Crete for the performance of bull-leaping and related ac. tivities, and these events may have been central to the identity of the palace. ${ }^{268}$ The dissemination of Knossian iconography and artistic techniques to other Minoan sites, especially toward the end of the Neopalatial period, appears to be part of a deliberate scheme.

\section{Writing and Administration}

Sealing administration began in the Near East in the sixth millennium B.C. followed by writing ca. 3100, but it is unlikely that Crete had administrative systems before the beginning of the MM period. An administration at Knossos may have been using sealings in the Prepalatial period, in MM I, but the practice becomes widespread in Crete only in MM II. ${ }^{269}$

Cretan Hieroglyphic writing makes a first appearance in MM IA, shortly before the rise of the first palaces. ${ }^{270}$ Although the Hieroglyphic script dies out at the beginning of the Neopalatial period, ${ }^{271}$ its genesis is important because it is the first Aegean

\footnotetext{
268 Younger (supra n. 254); Hallager and Hallager (supra n. 113); Rehak (supra ns. 132-33).

${ }^{269}$ Hallager I, 21-25; J. Weingarten, "The Sealing Structures of Minoan Crete," OJA 5 (1986) 279-98, and OJA 7 (1988) 1-25; Weingarten, "Three Upheavals in Minoan Sealing Administration," Aegaeum 5 (1990) 105-20; Weingarten, "The Sealing Studies in the Middle Bronze Age, I: Karahöyük, II: Phaistos," in P. Ferioli et al. eds., Archives before Writing (Rome 1994) 261-96; Weingarten, "Sealings and Sealed Documents at Bronze Age Knossos," in Evely et al. (supra n. 1) 171-88.

270) J.P. Olivier and L. Godart, Corpus hieroglyphicarum inscriptionum Cretae (Paris 1996) (=CHIC) presents the primary evidence; add A. Lembesi, P. Muhly, and J.P. Olivier, "An Inscription in the Hieroglyphic Script from the Syme Sanctuary, Crete (SY Hf 01)," Kadmos 34 (1995) 63-77. Hieroglyphic uses 96 syllabograms, 34 logograms, nine fractions, and a few other signs as adjuncts and punctuations. $C H I C$ catalogues a corpus of 331 Hieroglyphic inscriptions, the majority of which are seals or seal impressions. The script is basically pictographic (CHIC 19). Within the Protopalatial period, there is at least one other script, that which appears on the Phaistos Disc; the inscription on the Arkalochori ax is similar, but perhaps distinct: Godart (supra n. 223); J.P. Olivier, "Le Disque de Phaistos," BCH 99 (1975) 35-44. MM IA examples: CMS II.1, no. 391 (CHIC 315), no. 393 (CHIC 252), and no. 394 (CHIC 202).

271 No inscribed Hieroglyphic material comes from a Late Bronze Age context. Material from late contexts includes either Hieroglyphic sealstones (e.g., CMS V, Suppl. 1B, no. 337, CHIC [supra n. 270] 289, and CMS II.2, no. 256, CHIC 293) or nodules impressed by Hieroglyphic sealstones (e.g., CHIC 138, 152, 153, and 155). See also the jar stopper AM 1938.1153b: I. Pini, "Eine Tonplombe aus Knossos im Ashmolean Museum," Kadmos 21 (1982) 1-4.

272 For a basic introduction to Linear A and B, with bib. liography, see J.T. Hooker, Linear B: An Introduction (Bristol 1980) 11-18. GORILA presents the inscriptions. From Knossos, a tablet and one or two nodules/noduli from below
}

linear script and with it we see the beginning of ad. ministrative practices that will remain fairly constant throughout the Neo- and Final Palatial periods.

Linear A develops in MM IIA and is the major writing system on Crete throughout the Neopalatial period; it does not survive this period long, if at all. ${ }^{272}$ Because Hieroglyphic and Linear A seem to share some signs, it is probable that Linear A derives in part from Hieroglyphic, though that does not necessarily imply that they represent the same language. Nevertheless, a number of sites use both Hieroglyphic and Linear A (Phaistos, Knossos, Mallia, Petras), and in MM II-IIIA Knossos was appar. ently using both contemporaneously. The development of Linear B out of A is probable and may have occurred at Knossos prior to the end of the Neo. palatial period or soon after. ${ }^{273}$ As a script and administrative tool, Linear B is considered below un. der "Final Palatial Administration." Cypro-Minoan, which lies outside the scope of this review, seems to have developed in large measure from Linear A as well. ${ }^{274}$

the South West House (MM IIA): AR 39 (1993) 68; Hallager I, 57. From Final Palatial contexts come three incised roundels from Chania (LM IIIAl context): KH Wc 2005, 2117, and 2118 (Hallager I, 52-53); a pithos from Knossos, the Unexplored Mansion (LM II context): GORILA 4, KN Zb 40 (M.R. Popham, Kadmos 15 [1976] 102-107); and a LM II-IIIA terracotta figurine from Poros Herakleion with a Linear A inscription: N. Dimopoulou, J.P. Olivier, and G. Rethemiotakis, $B C H 117$ (1993) 501-21; Rethemiotakis, in Techne 117-21.

${ }^{273}$ J.T. Hooker, The Origin of the Linear B Script (Salamanca 1979) 16-73; Hooker, "The Varieties of Minoan Writing," Cretan Studies 1 (1988) 169-89; Shelmerdine (supra n. 16) 559. Linear B at Chania seems so dependent on developments at Knossos (E. Hallager, M. Vlasakis, and B.P. Hallager, "New Linear B Tablets from Khania," Kadmos 31 [1992] 61-87) that J.P. Olivier, "KN $115=\mathrm{KH} \mathrm{115,"} B C H$ 117 (1993) 19-33 suggested that a Knossos scribe wrote tablet KH Ar 4; T.G. Palaima, "Ten Reasons Why KH $115 \neq$ KN 115," Minos 27-28 (1992-1993) 261-81 argued against the identification, and Olivier graciously withdrew his sug. gestion at the Politeia conference in 1996. Early tablets at Pylos also exhibit a close relationship with Knossian palae. ography: Palaima, "Evidence for the Influence of the Knossian Graphic Tradition at Pylos," in P. Oliva and A. Frolikova eds., Concilium Eirene 16.3, section 4: Mycenaeological Colloquium (Prague 1982) 80-84.

${ }^{274}$ Hooker (supra n. 272) 15-16, 18; J. Chadwick, "The Minoan Origin of the Classical Cypriote Script," in Karageorghis (supra n. 206) 139-43; T.G. Palaima, "Cypro-Minoan Scripts: Problems of Historical Context," in Y. Duhoux, T.G. Palaima, and J. Bennet eds., Problems in Decipherment (Louvain-la-Neuve 1989) 121-67; Palaima, "Ideograms and Supplementals and Regional Interaction among Aegean and Cypriot Scripts," Minos 24 (1989) 29-54. Only two documents, both from Enkomi, are apparently contemporary with the major use of Linear A: L. Godart and A. Sacconi, "La plus ancienne tablette d'Enkomi et le Linéaire A," in Karageorghis (supra n. 206) 128-33. 
As a script, Linear $A$ is complex, and its corpus is also greatly varied. ${ }^{275}$ In stark contrast to the Hieroglyphic corpus, no sealstone carries a Linear A inscription, while the many kinds of objects that carry Linear A are restricted almost exclusively to clay tablets, nodules, and stirrup jars for Linear B. The bulk of Linear A documents comes from MM III and LM I contexts. ${ }^{276}$ The three Linear A documents from Phaistos that may also date to the Neopalatial period may imply that Phaistos was operating administratively at that time. ${ }^{277}$

There are four types of Linear A clay documents (fig. 5): tablets, roundels, nodules, and noduli. A distinction is usually made between inscribed (written) documents and those that are impressed by seals. Tablets are never impressed, while nodules may, or may not, be impressed and/or inscribed. Most Linear A tablets are page-shaped with the inscription ranked in rows, and all carry lists of commodities and personnel. ${ }^{278}$

Two types of monumental or conventional formulae are known, the "Libation Formula" and apparent gibberish, and these do not occur on tablets. The gibberish consists of several long inscriptions, usually not separated into word groups, on three gold hairpins, a bronze bowl, and a gold finger-ring; for the most part, except for the "JA-SA-SA-RA" on PL Zf 1 , they are hapax legomena. ${ }^{279}$ In full, the Libation Formula consists of a phrase or sentence of eight words inscribed on a wide variety of objects, stone libation tables, cups, ladles and altars, inked terracotta cups, and a silver pin, most of which were dedicated at peak sanctuaries. ${ }^{280}$ In its full form, and

${ }^{275}$ Linear A and B share 80 signs, both syllabograms and logograms, with four signs as variants unique to Linear A. In addition, like Linear B, Linear $\mathrm{A}$ has a long list of unique signs that appear rarely, only in conjunction with some other sign, or only as hapax legomena; 18 signs function as ideograms for vases; 154 ligatures serve as shorthand notations of commodities; and 13 simple and $30 \mathrm{com}$ plex fractions attest to a still baffling but precise measuring system. GORILA catalogues 1,487 inscriptions, almost all inscribed: 323 tablets, 887 nodules, 7 noduli, 178 roundels, 34 inscribed vessels, 3 graffito inscriptions in plaster, 2 inscriptions on architectural blocks, 8 inscriptions on metal objects (including a bowl, hairpins, and a gold ring), and 5 inscriptions on miscellaneous objects; 37 inscriptions were painted on vessels.

276 Site summaries in Hallager I, 39-77; add Thera: $A R$ 40 (1994) 69; Ergon 41 (1994) 56-62. MM IIIB: Knossos, Corridor of the Loomweights (southeast insula). MM III/LM IA: Knossos, East Temple Repository. LM IA: Gournia House Cf, Palaikastro Block B13, Akrotiri, Thera, $\Delta 8$ and the House of the Ladies. LM IB: Ayia Triada, Gournia House Fg and palace, Chania Kastelli House I and Odos Katre no. 10, Zakros House A and palace, Knossos Stepped Portico, Palaikastro Building V, Pyrgos, Sklavokambos, and Tylissos.

277 Two tablets, PH 1 (W.C. Brice, Inscriptions in the Mi. in Linear B values, the Libation Formula is as fol. lows: 1) T/A-TA-I.*301-; 2) word; 3) word; 4) J/A-SASA-RA; 5) U-NA-KA-NA-SI; 6) I-PI-NA-MA; 7) SI-RUTE; and 8) I-NA.JA-PA-QA.

The word J/A-SA-SA-RA has usually been assumed to be the name of a goddess allied with the Semitic AstartelAsshra. ${ }^{281}$ The final four words from U.NA. KA-NA-SI to I-NA-JA-PA-QA do not change. The first word T/A-TA-I-*301- appears in many variations that are difficult to resolve. Word $\mathbf{3}$ is always different, perhaps the name of the dedicant. The second word is often A-DI-KITE (or some variant) or I-DA (or some variant); six other words appear in this slot, includ. ing TU.RU.SA and SE-TO-I.JA. Since the last two are toponyms representing Tylissos and perhaps either Mallia or Archanes, ${ }^{282}$ and since A-DI-KITE and IDA look like the mountains Dikte and Ida, this slot in the Libation Formula appears reserved for a toponym.

Clay documents other than tablets can also be impressed and come in a wide range of shapes: documents that were not attached to anything (independent documents), documents that were pressed against something (direct-object sealings), and documents that hung from a cord (nodules or hanging nodules).

The Linear A roundel is a clay, disk-shaped independent document that could be written on one or both faces and/or impressed along the rim. As receipts for objects leaving the administrative centers, they record a word on one side, the ideogram for the commodity on the other, and on the rim a number of impressions of seals, presumably be-

noan Linear Script of Class A, 4 [Oxford 1961] 13; GORILA $1,286-87$ ) from the same repository 8 that produced the Phaistos Disk and MM IIIB pottery, and PH 3 (GORILA 1, 290-91) from a window sill in vano XLIV/38 (the lustral basin in the west magazines), and the inscribed nodule Wa 32 from vano 10 (GORILA 2, vii and 90). See also Fiandra (supra n. 31).

${ }^{278} \mathrm{~A}$ few tablets anticipate the later (and rarer) Linear B palm leaf-shaped tablet, a couple resemble Hieroglyphic labels, while a few are unique, roughly square. R. Palmer, "Linear A Commodities," in Politeia 133-55; D.W. Packard, Minoan Linear A (Berkeley 1974) 38-53.

${ }^{279}$ GORILA 4: Cr (?) Zf 1, KN Zf 13, KN Zf 31, KO (?) Zf 2, PL Zf 1. T.G. Palaima, "Comments on Mycenaean Literacy," Minos 20-22 (1987) 499-510.

${ }^{280}$ Schoep (supra n. 139); G.A. Owens, "Evidence for the Minoan Language: The Minoan Libation Formula," Cretan Studies 5 (1996) 163-208.

${ }^{281}$ G.A. Owens, "Astarte/Ishtar/Ishassaras/Asasarame: The Great Mother Goddess of Minoan Crete and the Eastern Mediterranean," Cretan Studies 5 (1996) 209-18; G. Huxley, "Cretan Paiawones," GRBS 16 (1975) 118-19.

282 G.A. Owens, "Minoan DI-KA.TA," Kadmos 32 (1993) 22-28; Owens, "Was se-to-i.ja at Archanes?" Kadmos 33 (1994) $156-61$. 
longing to the parties involved, that correspond to the number or amount of the commodities dispensed. ${ }^{283}$ Another independent document, the nodulus, is a lump of clay impressed by a seal and only rarely also inscribed; noduli may have served as dockets, "obligations to pay workers." 284

Other classes of small, lumpy clay documents were perforated, written on, and/or impressed. Most scholars give them the generic term "sealings" or "nodules." Sealings, as the term implies, however, seal objects directly-chests, boxes, jars, pegs (chest doors, storeroom doors?), and leather documents. ${ }^{285}$ Nodules secure the ends of string and hang from objects; they come in two forms, those into which the string entered at only one end (one-hole nodules) and those into which string entered at both ends (twohole nodules). One-hole nodules are thought to have occurred in pairs, each securing one of the two ends of a single piece of string that perhaps tied up papyrus documents. ${ }^{286}$ Two-hole nodules sealed the knot that ties together the two ends of one string, which was probably looped about an object.

The Protopalatial use of direct-object sealings (pegs and jars) continues selectively into the Neopalatial period. In the late Protopalatial period, how. ever, an entirely new set of clay documents is introduced for both Hieroglyphic and Linear A: tablets and noduli, one-hole and two-hole hanging nodules, and document sealings. ${ }^{287}$

Briefly, an administration uses a sealing system to monitor the reception, storage, distribution, and inventory of goods. ${ }^{288}$ Tokens may represent the en-

${ }^{283}$ Hallager; P. Rehak and J.G. Younger, "A Minoan Roundel from Pyrgos, Southeastern Crete," Kadmos 34 (1995) 81-102.

${ }^{284} \mathrm{~J}$. Weingarten, "Some Unusual Minoan Clay Nodules," Kadmos 25 (1986) 1-21; Hallager I, 121-33.

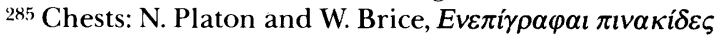

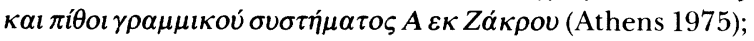
cf. Hallager I, 74-77. Jars: e.g., CMS V, Suppl. 1A, no. 149 from Chania; sealings from Knossos, Room of the Olive Press (Weingarten 1988 [supra n. 269] 2). Pegs (doors?): the majority of sealings from Lerna and Phaistos: P. Ferioli and E. Fiandra, "The Use of Clay Sealings in Administrative Functions from the 5th to 1st Millennium B.C.," Aegaeum 5 (1990) 221-32; Ferioli and Fiandra, "Change in the Juridical Significance of the Clay Sealing between the MM and LM in Crete and in the East," in M. Perna ed., Administrative Documents in the Aegean and Their Near Eastern Counterparts (Naples, forthcoming); J. Aruz, "Seal Imagery and Sealing Practices in the Early Aegean World," in Ferioli et al. (supra n. 269) 211-35; Weingarten 1994 (supra n. 269). One peg sealing is known from Knossos: Hallager II, 290 (KSPI L44). Documents: Hallager I, 135-58.

${ }^{286}$ E. Hallager, "The Hanging Nodules and Their Inscriptions," and M. Marazzi, "Sigilli e tavolette di legno," both forthcoming in Perna (supra n. 285).

${ }^{287}$ Hallager I, 31-38; II, 291. The Hieroglyphic crescent try of goods into the storerooms. The goods may be placed in containers sealed with an impressed sealing, have an impressed nodule hanging from them, or simply be left in a magazine whose door is tied closed with string and sealed with an impressed seal. ing. The clay sealings on the containers or on the doors constitute a "living archive."

Withdrawals should be of a standardized quantity, represented by the broken sealing or detached nodule that is reserved; the reserved nodules and seal. ings comprise a "temporary archive." At the end of the accounting period, the reserved nodules are brought together as a "final archive," like that at Pylos, and are counted and subtracted from the original amount. The total is then matched against the remaining amount of the commodity. Audited sealings are then discarded (a "discard archive") where they cannot be reinserted into the next administrative period to falsify later accounts. Favorite places for discarding sealings in the Neopalatial period are in closets under stairs; they are also used as fill in abandoned rooms or spaces, and in blocking walls. To be preserved, all clay documents need to be baked in a fire; since there is no evidence for any deliberate firing of documents, as exists in the Near East, all documents from Crete were fired in conflagrations, whether accidental or deliberate.

Living archives from Necpalatial Crete are rare, but several temporary archives have been excavated (e.g., the sealings in House A, Zakros), and one final archive of Linear A documents may survive from Chania, Odos Katre. ${ }^{289}$ Most impressed sealings,

and medallion may be related to the Linear A two-hole nodule and roundel, respectively.

${ }^{288}$ Younger (supra n. 112); T.G. Palaima, "Sealings as Links in an Administrative Chain," in P. Ferioli, E. Fiandra, and G.G. Fissore, Administration in Ancient Societies (Torino 1996) 37-66.

${ }^{289}$ Living archives: Hallager I, 39-77: Tylissos House A, the Knossos west magazines ( $G$-series), and the unidentified sealings that secured a gypsum chest containing tablets from the Room of the Column Bases, and perhaps from the "archives room" at Zakros: Platon and Brice (supra n. 285). J. Weingarten, "Late Bronze Age Trade within Crete," in Gale 1991 (supra n. 12) 305. Temporary archives: Hallager I, 73-74; Weingarten (supra n. 107). A personal visit to Zakros House A convinced us that the collapsed upper courses of the brick partition wall in room 7 had been misidentified in the original report as remains of a "brick chest." Other temporary archives (Hallager I, 39-77) include the sealings in the cupboard in room D, House 1 , in Chania, and the sealings from the cupboard in the blocked-up doorway at Sklavokambos. Final archive: Hallager I, 50-51. The deposit held 82 tablets, 112 roundels, 26 hanging nodules, 57 document sealings, and one nodulus found together in an ashy layer, perhaps having been tossed out in the cleanup after the fire destruction that burned the audit while still in progress. 
however, come from discard archives. In fact, the scatter of Linear A and B documents throughout the Knossos palace and the lack of any identifiable central archive strongly suggest that many of these deposits represent discard archives. This hypothesis has considerable consequences for the interpretation of the final destruction of Knossos, considered below under "Final Palatial Administration."

There are two major ways to analyze the patterns of seal use on impressed documents. One is to determine the frequency or "intensity" of a single seal's use within a deposit. When seals are used only a few times each to impress documents, it may imply, for instance, that members of the rural populace were sending their individual contracts or contributions to the central administration. When a few seals are used many times to impress documents, it may reflect an internal administration with a limited number of palace bureaucrats sealing and unsealing commodities and storerooms many times over the course of an administrative period. A document can be impressed several times by one seal (Weingarten's Single Seal System, or SSS) or by two or more seals in combination (the Multiple Seal System, or MSS). ${ }^{290}$ The SSS presumably involves a single person responsible for impressing a document, while the MSS requires two or more people to authenticate or administer a document together. The two systems can be found at the same site. ${ }^{291}$ Such analyses allow us to envision in some detail a Neopalatial administration's concern with incoming goods from the outlying areas and with the internal management of these goods. In the debate over whether these Neopalatial sites, including Knossos, were palatial or domanial in character, deposits like those at Zakros, where the

290) Weingarten (supra n. 107) and Weingarten 1988 (supra n. 269). Some caution needs to be exercised when translating seal use into personnel, however. Tomb evidence demonstrates that a single individual could own more than one seal (I. Pini, CMS V, Suppl. 1A, xviii), and it can be shown that the several faces of a single multifacial seal could impress a single document (e.g., Knossos Wc 41, Hallager II, 166-67; Samothrace Wc 2, Hallager II, 200-201). Thus, not all MSS documents need to have been impressed by two or more people.

291 Of the approximately 525 nodules in House A at Zakros, 360 (69\%) were MSS documents impressed by two or three seal faces, while $165(31 \%)$ were SSS documents impressed by one seal face only. The SSS seals belonged to the Cretan Popular group, common throughout the is. land, and perhaps reflecting a rural population; the MSS seals, however, belonged to the so-called "Zakro Master" group, distinctive of Zakros, perhaps belonging to members of the administration; Weingarten 1988 (supra n. 269) 46.

292 Weingarten 1988 (supra n. 269) 16 n. 15, citing J. Bennet, "The Structure of the Linear B Administration at Knossos," AJA 89 (1985) 247 and n. 76. T.G. Palaima, "Seal-Users
MSS dominates, seem to reflect the management of an estate rather than a state-management. ${ }^{292}$

While some classes of impressed documents ap. pear in virtually every sealing deposit in Crete, others appear to be restricted to individual sites: one-hole hanging nodules, for instance, are so characteristic of Ayia Triada that the few found at Zakros may imply some communication, perhaps written on papyrus, from Ayia Triada. ${ }^{293}$

Numerous seals carry almost identical scenes and can be distinguished from each other only with difficulty; they may have belonged to administrators who functioned similarly. ${ }^{294}$ Several of these "lookalikes" were gold rings with bull-leaping scenes, used to impress documents found at numerous sites. For example, one of these rings impressed three leather document sealings found at Ayia Triada, two document sealings from Sklavokambos, and two noduli, one from Gournia and one from the Zakros palace. It may be that the administrators traveled, or, more likely, impressed the documents at one regional center and sent them out to others. If the gold rings belonged to an elite administration at Knossos, the leather documents may have concerned sociopolitical and ceremonial (perhaps ritual or religious) issues. $^{295}$

It is usually assumed that the pre-Classical language of Crete was not Greek. Ancient writers describe the Cretans as sui generis. Eteo-Cretans and Pelasgikoi lived in eastern Crete in Classical times; and, as if to confirm the presence of non-Greek speakers, Classical and Hellenistic inscriptions have been recovered from East Crete, written with Greek letters but reflecting a non-Greek language. ${ }^{296}$

It is a common practice, called "normalizing, to

and Script-Users: Nodules and Tablets at LM IB Hagia Triada," in Ferioli et al. (supra n. 269) 307-30 argues for a greater administrative purview; he estimates Ayia Triada's agricultural territory as about $830 \mathrm{ha}$. This amount of land would fit comfortably in the immediate area, between the Geropotamos River and the western foothills of the As. terousia Mountains, and would resemble the territories of other and similar regional centers: P. Rehak and J.G. Younger, "Minoan and Mycenaean Administration in the Early Late Bronze Age: An Overview," forthcoming in Perna (supra n. 285).

293 Weingarten (supra n. 289) 305.

${ }^{294}$ Hallager I, 205-24; J.H. Betts, "New Light on Minoan Bureaucracy," Kadmos 6 (1967) 15-40.

295 Hallager and Hallager (supra n. 113); Younger (supra n. 254); Rehak (supra ns. 132-33); Rehak and Younger (supra n. 292).

${ }^{296}$ Hom. Od. 19.177; Hdt. 7.171. M. Guarducci ed., Inscriptiones Creticae (Rome 1942) III, "Tituli Cretae Orientalis," VI, nos. 1-6 from Praisos; add RPhil 20 (1946) 131-38. For Eteo-Cretan: Y. Duhoux, L'Étéocrétois: Les textes, la langue (Amsterdam 1982); and H. van Effenterre, "De l'Étéocrétois à la selle d'agneau," BCH 113 (1989) 447-49. 
assign Linear B phonetic values to similar-looking Linear A signs for convenience. ${ }^{297}$ When normalized, Linear A reveals some similarities to Linear $B$ : a few Linear A words can be recognized in Linear $\mathrm{B}$, including toponyms, and many of the ideograms seem the same. It is also likely that the unit of capacity in Linear A was the same as that in Linear B, 28.8 liters. ${ }^{298}$ Linear A, however, exhibits a significantly reduced o-series (in Linear A, no DO, JO, $\mathrm{MO}, \mathrm{NO}, \mathrm{QO}, \mathrm{SO}$ ) and the apparent tendency to use a final $\cdot u$ where Linear $B$ uses final $\cdot 0$.

There are too few Linear A documents to give any complete sense of grammar, but the repetitions of word stems with varied endings within the Libation Formula suggest some inflections. ${ }^{299}$ As for vocabulary, it is certain from their context that KU-RO means "total" and PO-TO-KU-RO means "grand total"; KI-KI-NA might mean "fig(s)," and TA-RA should mean "five." ${ }^{300}$ In addition to the identification of the AB ideograms, special Linear A ideogram *A302 may signify olive oil and *A303 grain.

Several languages have been proposed for Linear A based on resemblances in vocabulary: Semitic, especially East Semitic, and some Indo-European languages like Greek, Luvian (a southwestern Anatolian dialect of Hittite), and Lycian. ${ }^{301}$ Of these proposals, Semitic and Luvian are attractive for historical reasons: Semitic because of the evidence of trade con-

297 In only a few cases can it be demonstrated that the same word or its derivative appears in both Linear A and B, and from these only 12-15 Linear A signs can be assigned Linear B phonetic values with any confidence (DA, I, JA, KI, PA, PI, RO, RI, SE, SU, TA, O, and possibly TE, A, KO): L. Godart, "Du Linéaire A au Linéaire B," in Aux origines de l'Hellénisme (supra n. 242) 121-28.

298 A pithos from Epano Zakros carries an inscription (GORILA 4, 112: ZA Zb3) that begins with "VIN 32," probably recording the volume, 32 units; if Mycenaean units, the volume would have been 921.61. Since the pithos stands about $170 \mathrm{~cm}$ high, the vase-capacity program ("Vase" by Gregory Christiana, copyright 1994) calculates its maximum volume from its profile as slightly over $1000 \mathrm{l}$. If this is correct, both Palmer (supra n. 38) 37 and Palaima (supra n. 292) 327-28 n. 62 underestimate the size of the pithos.

299 E.g., JA-SA-SA-RA, JA-SA-SA-RA-MA-NA resembles IPI-NA-MA, I-PI-NA-MI-NA; U-NA-KA-NA-SI resembles UNA-RU-KA[ ]JA-SI and DI-DI-KA-SE; and U-NA-RE-KA-NATI resembles DI-DI-KATI. Packard (supra n. 278) 75-80.

${ }^{300}$ J.P. Olivier, “'Cinq' en Linéaire A?" in B. Brogyanyi and R. Lipp eds., Historical Philology: Greek, Latin, and Romance (Amsterdam 1992) 135-36.

301 J.T. Hooker, "Problems and Methods in the Decipherment of Linear A," Journal of the Royal Asiatic Society 1975, 164-72. J.P. Olivier, “Lire' le Linéaire A?” in Le Monde grec, pensée, littérature, histoire, documents: Hommages à Claire Preaux (Brussels 1975) 441-49. East Semitic: C.H. Gordon, Evidence for the Minoan Language (Princeton 1966); Gordon, "The Semitic Language of Minoan Crete," in Y.L. Arbeitman and nections between Crete and the eastern Mediterranean, and Luvian because of the close ceramic connections between southwestern Anatolia and Crete, especially in the Neolithic and Early Bronze Age. It should be remembered, however, that lexical resemblances do not specify a language; grammar and syntax do, and too little of either is known securely for Linear A.

\section{Trade and Interconnections}

Closely tied to issues of production, exchange, and administration within Crete during the Neopalatial period are questions concerning the nature of $\mathrm{Mi}$ noan trade and interconnections with other cultures of the Aegean and the eastern Mediterranean. Much work has been done in this area, with several international conferences in the last 15 years devoted entirely to aspects of the subject. ${ }^{302}$ Although the most attention continues to be paid to pottery (both imported and exported $)^{303}$ and to metals, especially copper and tin, recent interest has concentrated on Neopalatial Crete's contacts with all surrounding areas, both within and outside the Aegean, and on the cultural correlates that accompany such contact.

The origins of Neopalatial trade must be sought in the Protopalatial period. ${ }^{304}$ MM II pottery has been found at many sites in the Cyclades, and espe. cially the island of Aegina, Cyprus and the eastern

A.R. Bomhard eds., Bono homini donum (Amsterdam 1981) 761-82. For arguments against this identification, see Hooker 1988 (supra n. 273). Greek: G. Nagy, "Greek-like Elements in Linear A,” GRBS 4 (1963) 181-211. Luvian: E.L. Brown, "The Linear A Signary: Tokens of Luvian Dialect in Bronze Age Crete," Minos 27-28 (1992-1993) 25-54; Brown, "Minoan Linear A: The Luvian Thesis Revisited," American Philological Association Abstracts of the 126th Annual Meeting 147. Lycian: M. Finkelberg, "Minoan Inscriptions on Libation Vessels," Minos 25-26 (1990-1991) 43-85.

302 Papers in Thalassocracy, Gale (supra n. 12), C.W. Zerner and P.Z. Zerner eds., Wace and Blegen: Pottery as Evidence for Trade in the Aegean Bronze Age, 1939-1989 (Amsterdam 1993), and Aegean and Orient. See also J.N. Coldstream, "Kythera and the Southern Peloponnese in the LM I Period," TAW I, 389-401; J.L. Davis, "Minos and Dexithea: Crete and the Cyclades in the Late Bronze Age," in J.L. Davis and J.F. Cherry eds., Papers in Cycladic Prehistory (Los Angeles 1979) 143-57.

303 B.J. Kemp and R.S. Merrillees, Minoan Pottery in Sec. ond Millennium Egypt (Mainz 1980); V. Hankey, "Pottery as Evidence for Trade," in Zerner and Zerner (supra n. 302) 109-16; Hankey and A. Leonard, "Aegean LB I and II Pottery in the East," in Aegean and Orient. Kommos III, 156-83 gives a summary of Minoan pottery found abroad and of foreign pottery found in Crete.

304 Watrous (supra n. 1) 711-12, 734-35, 747-50. In A $\boldsymbol{e}$. gean and Orient: P.P. Betancourt, "Middle Minoan Objects in the Near East"; and L.V. Watrous, "Egypt and Crete in the Early Middle Bronze Age." 
Mediterranean, and Egypt; and close ties existed between Crete and Kastri on Kythera, and perhaps Samothrace. ${ }^{305}$ Minoan contacts with northern and southern Syria were apparently well established, and much of the Egyptian influence on Crete at this time may have come through port towns like Byblos. ${ }^{306}$ Ugaritic texts relate how the goddess Anat sent her messenger, Quadesh wa-Amrur, by way of Byblos to the land of Kaphtor, probably Crete, ${ }^{307}$ from where he was to return with the god of crafts, Kothar wa-Hasis, to build and embellish a palace for Anat. But the primary focus of Minoan interest in Anatolia and Syria in both the Protopalatial and Neopalatial periods is likely to have centered on the metals trade, particularly tin. ${ }^{308}$ If so, the evidence for Protopalatial contact with Cyprus, and Cypriot copper, seems slight, while Middle Cypriot II sherds have been found at Zakros and Mallia in early Neopalatial levels, and some White-Painted Cross Line pottery occurs at Kommos. 309

In LM I, however, there is a veritable wave of im. ported pottery. Much Cycladic pottery, especially from Thera, is imported into East Crete and to Kommos, which also receives some imported Mycenaean wares, while Central Cretan pots are exported to Thera. LM I also sees the most contact between Crete and Cyprus: Cypriot pottery is imported in some quantity, and much LM IA and B pottery is exported

305 Kythera: Sakellarakis (supra n. 213); Coldstream and

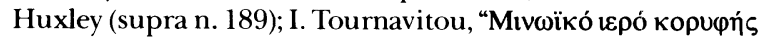

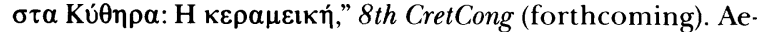
gina: W.-D. Niemeier, in Politeia 73-78. Samothrace: D. Matsas, in Politeia 235-47.

${ }^{306}$ O. Tufnell and W.A. Ward, "Relations between Byblos, Egypt and Mesopotamia at the End of the Third Millennium B.C.," Syria 43 (1966) 165-241; M. Saghieh, Byblos in the Third Millennium B.C. (Warminster 1984).

${ }^{307}$ N.H. Walls, The Goddess Anat in Ugaritic Myth (Atlanta 1992). G.A. Wainwright, "Asiatic Keftiu," AJA 56 (1952) 196-212 attempts to locate the Keftiu in northwestern Syria or southeastern Anatolia.

${ }^{308}$ G. Dossin, "La route d'étain en Mésopotamie au temps de Zimri-Lim," RAssyr 64 (1970) 97-106; A. Malamat, "Syro-Palestinian Destinations in a Mari Tin Inventory," IEJ 21 (1971) 31-38.

${ }^{309}$ L.V. Watrous, "Late Bronze Age Kommos," Scripta Mediterranea 6 (1985) 7-11, esp. 7. Banou (supra n. 34) 174; Knapp (supra n. 207).

310 Cycladic pottery: Banou (supra n. 34) 171-72; Kommos III, 154-55; Jones 427. Interaction between Crete and Cyprus: Banou (supra n. 34) 171-74; G. Cadogan, "Cypriot Objects in the Bronze Age Aegean and Their Importance," in V. Karageorghis, Acts of the First International Congress of Cypriot Studies (Nicosia 1972) 5-13; Cadogan, "Crete and Cyprus, c. 2000-1400 B.C.," in Karageorghis (supra n. 206) 63-68; C. Lambrou-Phillipson, "Cypriot and Levantine Pottery from House AD Center at Pseira," JAOS 110 (1990) 1-10; to Cyprus. Contact between the Levant and Crete intensifies in LM I. ${ }^{310}$ Although there is a minimum of Anatolian and Egyptian wares in Crete, a number of Canaanite amphoras attest to contact with the Levant, and LM I pottery is found throughout the Near East. ${ }^{311}$

In this regard it is difficult to know how to assess the evidence from pottery. We cannot assume, for instance, that the presence of a pot implies the presence of the people that produced it. ${ }^{312}$ Recent scientific analysis has shown that much of the pottery considered Minoan was actually locally produced. Raw bulk goods such as metal ingots can also be difficult to trace because, as already smelted copper, they were redistributed and reworked, and perish. able goods like foods and textiles have left few traces in Aegean contexts. The durable materials may simply be the surviving visible markers of a much more extensive trade in other goods. ${ }^{313}$ The wide range of the preserved contents of the Uluburun shipwreck has completely changed the way we imagine ancient trade. ${ }^{314}$

In 1980, Catling formulated his well-known paradox: in the Neopalatial period, there is much bronze in the Aegean, but little evidence for contact between the Aegean and Cyprus; in the Final Palatial period, the situation is reversed, with little Cypriot copper in the Aegean, but much Aegean pottery in Cy.

R.S. Merrillees, Trade and Transcendence in the Bronze Age Levant (SIMA 39, Göteborg 1974); Y. Tzedakis, "Kuлрıккท́

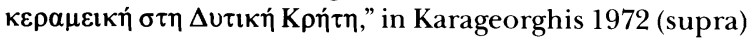
163-66; E.T. Vermeule, "Minoan Relations with Cyprus," TUAS 5 (1980) 22-24. A pithos from Pyla-Kokkinokremos may have been made at Chania: Jones and Day (supra n. 200) 263. Interaction between Crete and the Near East: a flask perhaps from Beycesultan and an Egyptian jug and jar come from LM IB levels at Kommos: Kommos III, 156, 162.

311 Banou (supra n. 34) 182-83; Lambrou-Phillipson (supra n. 310) 5-6; Zakros 341; AR 36 (1990) 73. A Canaanite amphora from Thera $\Delta 9$ (Thera VII, 30 pl. 96) contained East Cretan pots, implying a trade route. V. Hankey, "Late Minoan Finds in the South-Eastern Mediterranean," 3rd CretCong (1973) 104-10, esp. 104-108.

312 The "Harvey Thesis": Muhly (supra n. 206) 13.

${ }^{313}$ Muhly et al. (supra n. 205) 288 cite the following trade cycle: Assyrian merchants in Aššr used silver to buy tin from Afghanistan and textiles from Babylonia, exported them to their colony in the karum at Kaniš (modern Kültepe), where they traded them for twice the amount of silver, which they then brought, undoubtedly with Hittite textiles, back to Aššur.

${ }^{314}$ C. Pulak, seasonal reports in INA Newsletter, also on line: http://nautarch.tamu.edu/. G.F. Bass, "Prolegomena to a Study of Maritime Traffic in Raw Materials to the Aegean during the Fourteenth and Thirteenth Centuries B.C.," in Techne 153-70; Bass, "Sailing between the Aegean and the Orient in the Second Millennium B.C.," in Aegean and Orient. 
prus. ${ }^{315}$ Although more LM I pottery is now known from Cyprus, the copper at most Neopalatial sites still cannot be shown to come from Cypriot sources, and may instead be from Lavrion. ${ }^{316}$ The puzzle remains: if Minoans were not importing Cypriot copper to Crete in the Neopalatial period, why is their pottery found on Cyprus?317

In the Neopalatial period, there were at least three major Minoan trade routes within the Aegean: from Crete to Kythera, Laconia, and southwestern Messenia; the "Western String" of the Cyclades through Thera, Melos, and Kea, to the copper and silver mines at Lavrion; and the "Eastern String" through the Dodecanese to Anatolia and beyond. ${ }^{318}$ Crete was connected to the central and eastern Mediterranean largely through a single latitudinal route that connected the two regions but which ran along the north coast of Crete going east and along the south coast going west. ${ }^{319}$ From the east, the route proceeded counterclockwise up the Levantine coast, past Cyprus and the coast of Anatolia, through the straits of Rhodes to Karpathos, and south to Crete's Cape Sidero. Ships might then travel west along the north coast to enter the Gulf of Mirambello, but apparently the major route called for them to turn south to Zakros and Kommos, from where they could continue west or, taking advantage of prevailing winds and currents, head south across the Libyan Sea. The route from the west would have reached Crete at Chania, continuing along the north coast to Knossos.

According to these models for the principal trade routes, Minoans would have come into contact with the peoples of the western and eastern Mediterranean primarily in the various harbors and emporia along the routes themselves, and with the Mycenaeans directly in the southern Peloponnese and indirectly in the Cyclades, primarily on Thera and

\footnotetext{
${ }^{315}$ Knapp (supra n. 207).

316 Knapp (supra n. 207) 57. Gale 1985 (supra n. 204).

317 J.D. Muhly, "The Development of Copper Metallurgy in Late Bronze Age Cyprus," in Gale 1991 (supra n. 12) 187.

${ }_{318}$ J.L. Davis, "The Earliest Minoans in the South-East Aegean," AnatSt 32 (1982) 33-41; Davis (supra n. 16) 706; Sakellarakis (supra n. 213); G.S. Korres, "Messenia and Its Commercial Connections in the Bronze Age," in Zerner and Zerner (supra n. 302) 231-48 argues against Minoan influence on Messenian tholoi.

${ }^{319}$ Kommos III, 180 and fig. 10; G.W. Harrison, "Background to the First Century of Roman Rule in Crete," Cretan Studies 1 (1988) 145, citing these trade routes to explain the ideal situation of Gortyn as the Roman capital of the province Crete-Cyrene.

${ }^{320}$ J.F. Cherry and J.L. Davis, "The Cyclades and the Greek Mainland in LC I: The Evidence of Pottery," AJA 86 (1982) 333-41; C. Gillis, "Akrotiri and Its Neighbors to the South: Conical Cups Again,” TAW III.1, 98-116; M. Mar-
}

Melos. ${ }^{320}$ It is unlikely, however, that Minoan trade and contact with all these areas remained unchanging throughout the Neopalatial period. While trade with Cyprus apparently remains relatively steady from MM into Postpalatial times, contact with Syria seems to quicken in LM I and with Italy and Sardinia at the end of the Final Palatial period.

Trade, which may originate in part from a desire of local elites to obtain certain goods, can be considered from a number of different viewpoints: society, politics, technology, and distance. ${ }^{321}$ Four models seem particularly useful in assessing the multiple functions of trade: centralized control, localized control, independent or entrepreneurial trade, and ceremonial or gift exchange. ${ }^{322}$ The first assumes that trade was organized by a central authority, like the legendary thalassocracy of King Minos, for which there is very little concrete evidence. A model of localized control assumes the existence of "gateway" communities as a conduit for the transfer of commodities (especially metals) and finished products to subsidiary centers. ${ }^{323}$ Independent or entrepreneurial trade models assume that some traders coexisted alongside merchants controlled or administered by the state. Finally, ceremonial or gift exchange may involve aspects of the other models, since its principal aim is not to gain a material advantage but rather to create stable relations and establish social ranking. This last function is a particularly important aspect of chiefdoms. ${ }^{324}$

The nature of the relationship between Crete and the Aegean islands in the Neopalatial period demands some explanation and characterization. Crete may have been primarily interested in the copper and silver deposits at Lavrion. By LM IB, both Minoans and Mycenaeans were present at Ayia Irini in Kea, where much of the working of the Lavrion

thari, T. Marketou, and R.E. Jones, "LB I Ceramic Connections between Thera and Kos," TAW III.1, 171-84; J.C. Poursat, "Craftsmen and Traders at Thera: A View from Crete," TAW III.1, 124-27; J.A. MacGillivray, "Priest-Kings and Keftiu: Knossos and Thebes in the Eighteenth Dynasty," in Aegean and Orient, reports that the Lisht jug was locally made.

${ }^{321}$ A.B. Knapp, "Mediterranean Bronze Age Trade: Distance, Power and Place," in Aegean and Orient.

322 A.B. Knapp and J.F. Cherry, Provenience Studies and Bronze Age Cyprus (Madison 1994) esp. ch. 4. See also E. Brumfiel and T.K. Earle eds., Specialization, Exchange, and Complex Societies (New York 1987); F.A. Gunder, "Bronze Age World System Cycles," CurrAnthr 34 (1993) 383-429.

323 These categories are paraphrased from N.P. Kardu. lias, review of Knapp and Cherry (supra n. 322), JFA 23 (1996) 118-21, esp. 120.

${ }^{324}$ T.K. Earle ed., Chiefdoms: Power, Economy, and Ideology (New York 1991). 
ores was taking place. For the making of bronze, nowever, Crete may have been the sole possessor of tin. receiving it from the east. Such a monopoly might have created tensions. If Akrotiri was the mutual emporion for both Cretan and mainland trade, ${ }^{325}$ the eruption of the island might have caused a significant disruption in Crete's access to Lavrion and the mainland's access to Minoan bronze.

Since we do not know who the rulers in Neopalatial Crete were, we do not know how centralized the Minoan trade with the Cyclades was. ${ }^{326}$ Proponents of a thalassocracy ruled by Minos have based their argument on anachronistic sources like Thucydides, who was attempting to justify the Athenian imperialism of his own day, or on the distribution of Aegean sites named Minoa and the mythological stories that record the conquests of Minos. ${ }^{327}$

A natural corollary to the notion of a Minoan thalassocracy is the suggestion by Diodorus Siculus (5.54.4) that the Cretans established colonies on several Aegean islands. ${ }^{328}$ Evans had even postulated that Minoan settlers on the mainland were responsible for the rise of Mycenaean civilization, a theory that is now largely discounted. ${ }^{329}$ Since there are many types of colonies in addition to the Classical Greek model, ${ }^{330}$ including trading and agricultural colonies, scholars need to make their definitions clear. Another important aspect to be considered

325 The relatively higher incidence of Cycladic, as opposed to Minoan, pottery in the Mycenae Shaft Graves (J. Rutter, AJA 97 [1993] 791-93) suggests that until the end of LM IA, much trade with the mainland may have been in the hands of Cycladic islanders. M. Marthari, "The Ceramic Evidence for Contacts between Thera and the Greek Mainland," in Zerner and Zerner (supra n. 302) 249-56 notes that of the pottery at Thera, $85 \%$ is local and $15 \%$ imported, of which less than $2 \%$ is from the mainland. Z.A. Stos-Gale and N.H. Gale, "The Role of Thera in the Bronze Age Trade in Metals," TAW III.1, 72-90. There are also relatively few pieces of Early Mycenaean pottery from Crete (e.g., a LH IIA spouted jug found at Palaikastro, $P M$ II.2, 490 fig. 296a), but examples are increasing.

${ }^{326}$ C. Mee, review of Rehak (supra n. 39), CR 46 (1996) 380-81; A. Farnoux, “La fondation de la royauté minoenne," in Politeia 323-33.

327 Thuc. 1.4. S. Morris, "Prehistoric Iconography and Historical Sources," in Eikon 205-11; C.G. Starr, "The Myth of the Minoan Thalassocracy," Historia 3 (1953) 282-86. See also various authors in Thalassocracy; $\mathrm{M}$. Wiener, "The Isles of Crete? The Minoan Thalassocracy Revisited," TAW III.1, 128-60; Wiener (supra n. 205) 325-30; M. van Effenterre and $H$. van Effenterre, "Menaces sur la thalassocratie," in R. Laffineur ed., Thalassa (Aegaeum 7, Liège 1991) 267-70; and G. Huxley, Minoans in Greek Sources (Belfast 1968).

${ }^{328} \mathrm{~J}$. Shaw, "Consideration of the Site of Akrotiri as a Minoan Settlement," TAW I, 429-36.

329 O.T.P.K. Dickinson, "Cretan Contacts with the Mainland during the Period of the Shaft Graves," in Thalassoc. is that colonization always involves the development of ethnic identities that both the motherland and the colony share yet make distinct.

Several Aegean sites have been proposed as $\mathrm{Mi}$ noan colonies because they exhibit Minoan domestic pottery (imported and locally made), evidence for Minoan cult, the use of Minoan burial customs, and Minoan architectural and decorative styles: Kythera, Ialysos and Trianda on Rhodes, Seraglio on Kos, and Miletos. ${ }^{331}$ It should be stressed, however, that these excavations are quite small, sometimes not much more than a few trenches, and generalizations should be offered cautiously. By contrast, the extensively excavated and heavily Minoanized sites of Phylakopi, Akrotiri, and Ayia Irini are generally not considered colonies.

Sometimes included in discussions of a possible Cretan thalassocracy is the imitation outside Crete of Minoan building styles, pottery, and art without imputing Minoan political and military control, called the "Versailles effect" after the tendency to imitate court styles at Versailles in areas of Europe outside French political control. ${ }^{332}$ Similarly, Linear A may have served as a common script for business purposes outside Crete without indicating political domination by the Minoans, just as English and German are widely used in international business transactions today. ${ }^{333}$

\footnotetext{
racy $115-17$.

${ }^{330}$ R. Hägg and N. Marinatos, in Thalassocracy 222.
}

331 Kythera (supra n. 305). Ialysos: T. Marketou, BICS 41 (1996) 133-34; AR 41 (1995) 58. Trianda: AR 38 (1992) 58-59. Seraglio in Kos town, MM-LM IIIC: $A R 36$ (1990) 70. Miletos: W.-D. Niemeier, "New Excavations in Bronze Age Miletus, 1994," BICS 40, n.s. 2 (1995) 258-61; Niemeier (supra n. 11); Niemeier, "Recent Excavations at Miletus," in Aegean and Orient.

332 The militarism of the early Late Bronze Age, which has been considered a sign of both Minoan and Mycenae. an influence, is now seen as a general characteristic of the entire Aegean in this period: S.W. Manning, "The Military Function in Late Minoan I Crete," WorldArch 18 (1986) 284-88. The file of warriors in the Miniature Fresco from the West House at Akrotiri (Doumas pl. 28) could represent Mycenaeans, Minoans, or, more simply, Cycladic islanders; cf. the stele from Kea: J.L. Caskey, Hesperia 35 (1966) 363-76, esp. 175, pl. 90b. "Versailles effect": Wiener (supra n. 56).

333 Accepted Linear A inscriptions from Mycenae SG IV (PGC, no. 1411); Ayios Stephanos in Laconia (GORILA 5, HS Zg 1); Kea (GORILA 1, KE 1; 2: 80, Wc 2; 4, Zb 3-5); Melos (GORILA 4, MI Zb 1; 5, MI 2); Kythera (GORILA 4, KY Zg 1); Thera (GORILA 4, THE Zb 1-4; fragments of tablets and one more inscribed pithos: $A R 40$ [1994] 69; Ergon 41 [1994] 56-62; BCH 118 [1994] 791); Samothrace (CMS V, Suppl. 1 B, no. 327); Miletos (Niemeier [supra n. 331]). 
We can see clear architectural indications of the Versailles effect: polythyra at Akrotiri and Trianda; a lustral basin, light well, and ashlar architecture at Akrotiri; a pillar basement at Phylakopi; and a Minoan-style "parlor" in House A at Ayia Irini. On the mainland, one tholos at Peristeria has an ashlar facade with Minoan-style mason's marks, and similar blocks have been found reused at Pylos, Mycenae, and Colonna on Aegina. ${ }^{334}$

Another model to account for the spread of $\mathrm{Mi}$ noan Neopalatial culture in the Aegean is the sug. gestion that it had a religious underpinning. ${ }^{335}$ Later history provides well-documented examples for religion-based models of exchange, especially in "contact periods," where technological exchanges were tied (often unsuccessfully) to the adoption of religious beliefs (e.g., European contacts with Native American populations or with the Aborigines in Australia); a careful reading of such examples for the Aegean might give the necessary grounding for a systematic argument for a Minoan "threskeiocracy." 336

334 Pylos: a double ax on a block at Pylos ( $P N$ I, 94, figs. 15-16). Mycenae: AB 58 on a stele fragment from Grave Circle A (E. Protonotariou-Deilaki, in Hägg and Nordquist [supra n. 221] 69-83, fig. 27); on blocks (PPS 97 [1953] 437) near the South House (trident), near the Acropolis Wall (a "chariot wheel": REG 18 [1905] 78), and on two reused poros blocks in the blocking wall of the Atreus dromos (a branch on both: ILN 23 Dec. 1939, 942; A.J.B. Wace, BSA 51 [1956] 119, pl. 25). Aegina: a double ax (Niemeier [supra n. 305] 78, pl. XV). Peristeria tholos 1: a double ax and a branch (AR 7 [1961] 13 fig. 11; Prakt 1960, pls. 158ß and $159 \alpha$ ). O.T.P.K. Dickinson, The Origins of Mycenaean Civilisation (SIMA 49, Göteborg 1977) 93 interprets the mason's marks on the Peristeria tholos to mean that it was planned by a Minoan.

335 N. Marinatos, "Minoan Threskeiocracy on Thera," in Thalassocracy 167-78; Marinatos, "Minoan-Cycladic Syncretism," TAW III.1, 370-76; Marinatos, "The West House at Akrotiri as a Cult Center," AM 98 (1983) 1-19; W.D. Niemeier, "Iconography and Context: The Thera Frescoes," in Eikon 94-107. Cf. M.A.S. Cameron, "Theoretical Interrelations among Theran, Cretan, and Mainland Frescoes," TAW II, 579-92.

${ }^{336}$ For recent studies of the motives and machinery for Classical Greek colonization, see I. Malkin, Religion and Colonization in Ancient Greece (Leiden 1987); and C. Dougherty, The Poetics of Colonization (Oxford 1993).

337 Thera: B. Rutkowski, "Religious Elements in the Theran Frescoes," TAW I, 661-64. From Troullos above Ayia Irini on Kea come a stone ladle, offering table, and a bronze figurine:J.L. Caskey, Hesperia 40 (1971) 392-95; Davis (supra n. 202) $164-65$, n. 24. From the Vathy Cave come an imported conical rhyton and a stone ladle: M. Benzi, in Zerner and Zerner (supra n. 302) 275-88, pl. 36c (ladle). Apollo Maleatas: V. Lambrinoudakis, in Sanctuaries 59-65; for the sanctuary's terracotta figurines, see E. Peppa-Papaioannou,

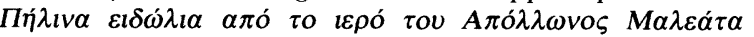

Certainly the physical evidence exists for a persuasive prima facie argument. Peak and cave sanctuaries of Minoan type can be postulated for Thera, Kea, the Vathy Cave on Kalymnos, and Apollo Maleatas at Epidauros, while an actual example of a Minoan peak sanctuary has now been excavated on Kythera ${ }^{337}$ From the peak on Kythera, it is possible to see the peak of Mt. Ida on Crete, and other lineof-sight networks may have existed from Kea to Thera, and from there to Crete. Minoan religious themes appear in frescoes outside Crete, and Minoaninspired terracotta statues were excavated at the temple at Ayia Irini on Kea. Many sites outside Crete have yielded Minoan cult equipment, including horns of consecration and offering tables, as well as prestige items like bull's head rhyta, maces, real or imitation tritons, and "game-boards."338 Exported stone chalices reflect Minoan wine-drinking rituals; ${ }^{339}$ compare the Tiryns ring (CMS I, no. 179) that depicts the enthroned goddess holding a chalice and attended by a file of genii with pitchers. Moreover,

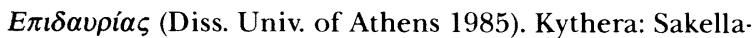

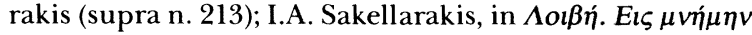

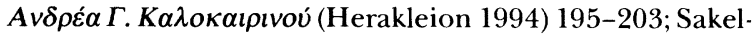
larakis and Olivier (supra n. 142).

${ }^{338}$ Frescoes: L. Morgan, "Island Iconography: Thera, Kea, Milos," TAW III.1, 252-66, esp. 259-60, fig. 8. Akrotiri: Immerwahr 185-88; Doumas. Ayia Irini: Immerwahr 188-89; Davis (supra n. 16) figs. 4-5. Phylakopi: Immerwahr 189-90; Davis (supra n. 16) fig. 13; recent excavations by the British School uncovered more fragments of the dolphin fresco and of another fresco with white lilies on a red background. Trianda: Immerwahr 190. Ramp House at Mycenae: Immerwahr 190-91; M.C. Shaw, BSA 91 (1996) 167-90. Argolid relief fresco (supra n. 183). Miletos (griffin): W.D. Niemeier, "Minoan Frescoes in the Eastern Mediterranean," in Aegean and Orient. Horns of consecration: Akrotiri (Thera VI, $34 \mathrm{pl}$. 83a) and Trianda ( $A R 38$ [1992] 58). From the mainland: S. Hood, "A Mycenaean Horns of Consecration," in $\Phi^{\prime} \lambda_{\imath} \alpha \dot{\varepsilon} \pi \eta$ (supra n. 151) 149. Cyprus: M. Loulloupis, "Mycenaean 'Horns of Consecration' in Cyprus," in V. Karageorghis ed., Acts of the International Archaeological Symposium "The Mycenaeans in the Eastern Mediterranean"(Nicosia 1973) 225-44. Offering tables: Phylakopi: AR 22 (1976) 26 and fig. 33. Thera: Prakt 1990, pl. 140a. Rhyta: Rehak (supra n. 132). Maces from Aegina and the Argolid: Kaiser (supra n. 140) 16, 17 fig. 4.40, pl. 7.4. Triton in blue faience from SG III at Mycenae: Karo 64-65 no. 166, pl. CXLVIII. Game-boards from Kakovatos and Mycenae: Foster 1979 (supra n. 250) 142-43.

399 Chalices: Akrotiri: Thera V, pls. 61, 67, 68; Prakt 1971, pls. 282-83; AR 41 (1995) 57. Ayia Irini: Cummer and Schofield (supra n. 158) 122 nos. 1499-1500, pl. 42. Mycenae: SG IV (NMA 600) and V (NMA 854). Miletos: Niemeier 1995 (supra n. 331) 261. Zakros: Zakros 144. Makriyialos: Davaras 1985 (supra n. 43) fig. 48. On drinking rituals, see Hamilakis (supra n. 38) 1-32. 
sealings impressed by Minoan seals and gold rings, the latter at least possibly used by religious person. nel, have been found in the islands from Samothrace to Thera. ${ }^{340}$

The extent to which these religious paraphernalia abroad reflect how deeply the people of the Cyclades and the mainland were affected by Minoan religious beliefs is unclear. Most of these objects in the Cyclades are found in habitation sites, however, while most of those on the mainland have been found in tombs. It is possible, therefore, that the Mycenaeans regarded Minoan religious items merely as prestige goods, and their possession as an indicator of status.

The second model, that of localized control, posits the existence of gateway communities from which raw materials and finished goods were sent on to subsidiary centers. Zakros is an obvious gateway with its hoard of unworked elephant tusks and metal ingots; in the Final Palatial period, Kommos seems to have fulfilled a similar function. Port towns such as Kythera, Akrotiri, and Poros Herakleion are likely places for different ethnic groups to have mixed. The contents of the rich tombs at Poros suggest that they served individuals with international connections. Thus, it is not impossible that some Mycenaeans were already present on Crete in LM IA. If so, were they sightseers, businessmen, mercenaries, or envoys? It also might be useful to coin a new term for some of these individuals, perhaps "warrior trader" or "mer. chant prince." 341

A third model of independent or entrepreneurial trade has been used to suggest that private merchants existed alongside royal merchants. This may

340 Late Protopalatial sealings: a peg sealing from Ayia Irini in Kea (CMS V, no. 479); and two cord sealings, two impressed noduli (one inscribed with NA-TA), and an impressed roundel from Samothrace (CMS V, Suppl. 1B, nos. $320-28)$. Neopalatial document sealings are now reported from Thera (Ergon 42 [1995] 52-54, figs. 37-38) impressed by rings depicting bull-leaping and a chariot, the latter duplicated on similar sealings from Ayia Triada (HMs 516; $P M$ IV, fig. 808) and Sklavokambos (HMs 632-35).

341 The later Lefkandi burial resembles both the Poros burials and the Vapheio prince: M.R. Popham and I. Lemos, "A Euboean Warrior Trader," OJA 14 (1995) 151-57.

342 A. Archi ed., Circulation of Goods in Non-Palatial Contexts in the Ancient Near East (Rome 1984).

34.3 PM I, 286-90, 288 fig. 220. E. Uphill, "User and His Place in Egypto-Minoan History," BICS 31 (1984) 213; cf. W. Ward, "Remarks on Some Middle Kingdom Statuary Found at Ugarit," UgaritF 11 (1979) 799-806. See also H.P. Wotzka, "The Abuse of User," BSA 85 (1990) 449-53.

344 The deposit dates to the 12th Dynasty, reign of Am- be assumed for Crete, if only because it can be documented even for the strongly centralized royal authorities of the eastern Mediterranean. ${ }^{342}$

The fourth model, ceremonial or gift exchange among rulers, is implied by some objects. For example, at least 25 statuettes of Middle Kingdom Egyp. tian envoys of the pharaohs are attested from Anatolia to Nubia; the stone figure of User found at Knossos in a chronologically problematic context must be one such figure. ${ }^{343}$ The reciprocal nature of such exchanges is indicated by the LevantineAegean silver cups deposited at Tôd in southern Egypt. ${ }^{344}$ The stone lid inscribed with the name of the Hyksos pharaoh Khyan, again from a controversial context at Knossos, also fits into this pattern, for other objects inscribed by this ruler have been found in Syria, Anatolia, and Mesopotamia. ${ }^{345}$ Another possible example of gift exchange is the presence of African blue monkeys or vervets (cercopithecus aethiops aethiops) in Knossian wall paintings, where they appear in ritual scenes; their importance must have been enhanced by their exotic quality. From Knossos, some of these monkeys may then have been shipped to Minoanized sites such as Akrotiri and Phylakopi, where they again appear in wall paintings. ${ }^{346}$

A variant of the "gift exchange" model is the Minoan or Minoanizing artistic koiné in the Aegean, elements of which we recounted above. This koiné consisted of geographically widespread similarities in special objects, techniques, iconography, and style, often so uniform that it is sometimes extremely difficult to separate Minoan from Mycenaean from Cycladic art; to some extent this Aegean koiné is part of a larger common culture within the eastern Med-

enemhat II. R. Laffineur, "Réflexions sur le trésor de Tôd," Aegaeum 2 (1988) 17-30; C. Lilyquist, "Granulation and Glass," BASOR 290-91 (1993) 35-36; K.R. Maxwell-Hyslop, "A Note on the Anatolian Connections of the Tôd Treasure," AnatSt 45 (1995) 243-50.

${ }^{345}$ PM I, 416-22, 419 fig. 304b; PGC 92 no. 1142, pl. 1142; M.J. Mellink, "New Perspectives and Initiatives in the Hyksos Period," Ägypten und Levante 5 (1995) 85-89. See also M. Liverani, "Dono, tributo, commercio," AIIN 26 (1979) 9-28.

${ }^{346}$ Helms 1988 and 1993 (supra n. 100). P.J. Parker, AJA 101 (1997) 348 (abstract); T.F. Strasser, AJA 101 (1997) 348 (abstract). We are particularly grateful to Parker for allow. ing us to read her unpublished M.A. thesis, Monkeys and Their Role in the Aegean Bronze Age, MM III-LM I (Univ. of Texas at Austin 1996). Depictions in wall paintings on Thera and Melos: Akrotiri, Xeste 3, rooms 3a and 4, and sector A: Doumas pls. 95, 122, 147. Phylakopi, the Pillar Crypt area: Morgan (supra n. 338) 256 fig. 7, 260. 
iterranean. ${ }^{347}$ Three technological innovations in the Aegean are probably the result of Syrian influence: cloisonné, granulation, and the niello technique of inlaying different colors of metal against a black background. The ceremonial ax of the Egyptian queen Aahotep employs the niello technique and includes the representation of a distinctively Aegean crested griffin. ${ }^{348}$ At the Syrian site of Kabri, floor and wall paintings in Minoan fresco technique have been uncovered, and other fresco fragments with Minoan elements have been identified in the decoration of the palace of Yarim Lin at Alalakh (level VII), well inland from Ugarit, and in the palace of Zimri Lim at Mari on the Upper Euphrates. ${ }^{349}$ The recent discovery at Tell el-Dab ${ }^{\circ}$ a in the Nile Delta of paintings in Minoan fresco technique and employ. ing a strongly Minoanizing iconography has been much discussed. ${ }^{350}$ Whether these paintings are to be dated to late in the Hyksos period or to the early 18th Dynasty (as now seems more likely), they should be contemporary with the end of the Neopalatial period (LM IB). The scenes published thus far are strongly suggestive of Knossian influence: the technique of fresco, the use of colored backgrounds, the iconography of bull-leaping, and bulls, griffins, and a leopard in flying gallop. Nonetheless, some aspects suggest an unfamiliarity with the details of Minoan iconography ${ }^{351}$ So far, there have been many interpretations of the meaning of these frescoes, but more likely than not they are simply symptomatic of an international cultural sophistication in the larger eastern Mediterranean. Like African blue monkeys in the Aegean, Minoan frescoes in the Levant and Egypt may have been of interest primarily because they were exotic.

${ }^{347}$ E.g., R. Laffineur, "Craftsmen and Craftsmanship in Mycenaean Greece," in Politeia 189-99. Wall painting: W.S. Smith, Interconnections in the Ancient Near East (New Haven 1965) figs. 126-28, 129b-c, 130, 134-37; CAH plates to vols. I-II (1977) pl. 66. Seals: B. Teissier, Egyptian Iconography on Syro-Palestinian Cylinder Seals of the Middle Bronze Age (Fribourg 1996); J. Aruz, "Syrian Seals and the Evidence of Cultural Interaction," CMS Beiheft 5 (Berlin 1995) 1-21.

${ }^{348}$ PM I, 551 fig. 402: detail of griffin; cf. the wing of the griffin from Xeste 3 at Akrotiri: Doumas pl. 128.

349 W.D. Niemeier, "Minoans and Hyksos: Aegean Frescoes in the Levant," BICS 40 (1995) 258-60; Niemeier (supra n. 338).

${ }^{350}$ E. Cline, "Rich beyond the Dreams of Avaris," BSA 92 (forthcoming); M. Bietak and C. Palyvou, "A Large Griffin from a Royal Citadel of the Early 18th Dynasty at Tell elDab'a," 8th CretCong (forthcoming); P. Rehak, "Interconnections between the Aegean and the Orient in the Second Millennium B.C.," AJA 101 (1997) 398-402.

351 The triglyph-half rosette is different from all Aegean examples, and bull-leapers are shown in anomalous positions, their costumes having been misunderstood: one bull-
While most studies of trade have concentrated on items that originate in one place and are found in another, we wish to point out one unusual pattern in Neopalatial trade: three items not found in Crete. One of the most obvious is the object decorated in niello. Virtually all Aegean niello work has been found in early and rich Mycenaean tombs on the mainland, but the iconography of these objects is strongly Minoan. Nonetheless, articles also in this technique come from Syria-Palestine and Egypt, and it seems likely that the technique originates in Syria. While it is difficult to imagine any Aegean workshop outside Knossos capable of producing them, Laffineur has intriguingly proposed a workshop at Mycenae staffed by Syrian craftsmen. ${ }^{352}$

Two materials are also found almost exclusively on the mainland: amber and amethyst. Most of the amber in the Aegean is of Baltic origin, and large quantities of it have been found in mainland contexts in LH I-IIA, but almost none is found from that period in the Cyclades or on Crete. ${ }^{353}$ Thereafter, the amounts declined markedly, as if little more was coming into the Aegean, and the existing supply was simply being redistributed; even then, little reached Crete. Amethyst, on the other hand, probably came from Egypt and into the Aegean via the eastern Mediterranean, perhaps in exchange for silver from Lavrion. Like amber, amethyst is found in quantity in early LBA funerary contexts on the mainland. Only a few amethyst beads and seals occur in Neopalatial Cretan contexts, however, and from LH/LM IIIA1 on, little amethyst is recorded anywhere in the Aegean. ${ }^{354}$

These items possibly point to three peculiarities in Aegean trade networks: a set of foreign craftsmen

leaper wears a cushion seal while only lentoids are depicted in the Aegean, and some bulls have been set against the backdrop of a textile pattern (often misleadingly referred to as a "maze" or "labyrinth"), a treatment without parallel in the Aegean but at home in Syria.

352 R. Laffineur, "From West to East," in Aegean and Orient. See also A. Xenaki-Sakellariou and C. Chatzilou, "Peinture" en metal à l'époque mycénienne (Athens 1989); M. Boss and R. Laffineur, "Mycenaean Metal Inlay," in Techne 191-97.

${ }^{353}$ H. Hughes-Brock, "Amber in the Aegean in the Late Bronze Age," in C.W. Beck, J. Bouzek, and D. Dreslerová eds., Amber in Archaeology (Prague 1993) 219-29.

354 I. Shaw and R. Jameson, "Amethyst Mining in the Eastern Desert," JEA 79 (1993) 81-97; Higgins (supra n. 232) 36; C.A.R. Andrews, Catalogue of Egyptian Antiquities in the British Museum VI: Jewellery I (London 1981) 95-96. N. Gale and Z. Stos-Gale, “Ancient Egyptian Silver," JEA 67 (1981) 103-15. Amethyst in funerary contexts: Argos: D. KazaPapageorgiou, AM 100 (1985) 19-20, pl. 3.7; Mycenae: A.J.B. Wace, Archaeologia 82 (1932) 208-209. Neopalatial amethyst beads: Poros Herakleion chamber tomb (Metaxa-Muhly [supra n. 95] 92 no. 258, pl. 27); Archanes Phourni, Tholos 
working on the mainland producing highly sophisticated niello objects in Minoan style for Mycenaean patrons; an imported material from the north, amber, that arrives in mainland Greece and is not shipped to Crete; and another imported material, amethyst from the east, which may be worked in Crete but, if so, is almost exclusively reserved for exportation to the mainland. In these three instances, Crete is a "present absence" that demands an explanation.

\section{Religion}

We know a great deal about Minoan cult locations and equipment, and practically nothing about belief systems for the Neopalatial period. ${ }^{355}$ Since Linear B makes available religious documents pertaining to the Final Palatial period, it is possible that a decipherment of Linear A or Hieroglyphic might provide some help, but the obviously religious texts are few and conventional, as noted above. ${ }^{356}$ The groundwork for the study of Minoan religion was laid at the beginning of the 20th century by Evans; his influence has been enormous and his views are still too often accepted uncritically, particularly his belief in a Great Mother Goddess and her Young Male Consort. Nearly half a century ago, Nilsson was unable to distinguish between Minoan and Mycenaean religion. ${ }^{357}$ Efforts in the last two decades have concentrated on identifying and separating the contributions of the two cultures. Nevertheless, much work remains to be done.

As in so many other areas, the origins of Neopa-

E (Archanes 127 fig. 104), MM IA, a date too early for local work. Seals: $C M S$ V, Suppl. 1A, no. 387, and B, no. 331 (color fig. on 467, h). Later contexts: a single bead comes from the West Shrine at Phylakopi (LH I-IIIAl context): C. Renfrew et al., The Archaeology of Cult: The Shrine at Phylakopi (London 1985) 64, 97, 319. Six globular beads from the Nichoria tholos (LH IIIA2-B1 context): W.A. McDonald and N.C. Wilkie eds., Nichoria II: The Bronze Age Occupation (Minneapolis 1992) 281 and n. 22.

355 D. Crawford, "Re-evaluating Material Culture," in Society 48-53; O.T.P.K. Dickinson, "Comments on a Popular Model of Minoan Religion," OJA 13 (1994) 173-84; Gesell passim; N. Marinatos, "Divine Kingship in Minoan Crete," in Rehak (supra n. 39) 37-47; Marinatos (supra ns. 97, 221); J. Wright, review of Marinatos (supra n. 97) in Bryn Mawr Classical Review (gopher:/gopher.lib.Virginia.EDU:70/11/ alpha/bmcr) 95.3.17, and Marinatos's reply, 95.8.11; F. Matz, Göttererscheinung und Kultbild im minoischen Kreta (Mainz 1958); B. Rutkowski, The Cult Places of the Aegean (New Haven 1986); I.M. Ruud, Minoan Religion: A Bibliography (SIMA-PB 141, Göteborg 1996); P. Warren, "The Beginnings of Minoan Religion," AntCr 1 (1973) 137-47; Warren 1988 (supra n. 174); L.V. Watrous, The Cave Sanctuary of Zeus at Psychro (Aegaeum 15, Liège 1996).

${ }^{356}$ A. Furumark, "Linear A and Minoan Religion," OpAth 17 (1988) 51-90. latial religion must be sought in the Protopalatial period. Even before the rise of the first palaces, the Minoans were making offerings, perhaps on a seasonal basis, at caves throughout the island and at sanctuaries on mountain peaks and mountainsides, such as Juktas near Knossos and Kato Syme on the south coast. Monumental architecture, as well as Hieroglyphic script for religious administration, appears at some of these locations prior to the appearance of the first palaces. Equally early are the communal tholos tombs, especially in the Mesara, which were used by extended families or communities for burials and for the veneration of their ancestors. Finally, with the appearance of the first palaces, small ritual rooms with equipment for the preparation of drink and food can be identified at habitation sites, along with other possible cult paraphernalia. It is not clear, however, that there was a unified set of cult practices or beliefs across Crete even in Protopalatial times, though the sporadic appearance of images of women has led some to hypothesize the existence of a major Minoan goddess. ${ }^{358}$ The figurines at peak sanctuaries, however, include both men and women, with the former outnumbering the latter.

At the beginning of the Neopalatial period, fewer peak and mountain sanctuaries remain in use but some now receive palatial dedications. ${ }^{359}$ Evidence for burial ritual and the burials themselves virtually ceases, while at the palaces and major centers cult equipment becomes much richer and more complex, and Linear A supersedes Hieroglyphic. These fac-

${ }^{357}$ MMR2; A.J. Evans, The Mycenaean Tree and Pillar Cult and Its Mediterranean Relations (London $1901=J H S 21$ [1901] 99-204). Also see Davis (supra n. 179); H. Waterhouse, "Priest Kings?" BICS 21 (1974) 153-54.

358 There is a chronological gap between the EM II "goddess" figurines from Myrtos and elsewhere (E. Fowden, "The Early Minoan Goddess," Journal of Prehistoric Religion 3-4 [1990] 15-18) and the first female terracotta figurines at peak sanctuaries. P. DuBois, Sowing the Body (London 1988) 47-49 and 132-36 refers to "feminiform" vases as signaling the common concept of woman as vessel.

${ }^{359}$ A. Peatfield, "The Topography of Minoan Peak Sanctuaries," BSA 78 (1983) 273-80; Peatfield, "Minoan Peak Sanctuaries," OpAth 17 (1990) 117-31; Peatfield, "Palace and Peak," in Palaces 89-93; Peatfield, "Rural Ritual in Bronze Age Crete: The Peak Sanctuary at Atsipades," CAJ 2 (1992) 59-87; L.V. Watrous, "Some Observations on Minoan Peak Sanctuaries," in Politeia 393-404; Rutkowski (supra n. 163); B. Rutkowski, "Minoan Peak Sanctuaries," Aegaeum 2 (1988) 71-98; N. Schlager, "Korakomouri," ÖJh 64 (1995) 1-24; K. Nowicki, "Some Remarks on the Pre- and Protopalatial Peak Sanctuaries in Crete," Aegean Archaeology 1 (1994) 31-48; I. Loucas and E. Loucas, "Sur le déclin des sanctuaires de sommet au minoen récent," in Laffineur (supra n. 31) 35-38. The decline of smaller peak sanctuaries has been read as part of a process of consolidation at a few large ones. 
tors suggest that the new palaces may have engaged deliberately in reorganizing and reforming Minoan religion along official lines. With the LM IB destructions that signal the end of the Neopalatial period, many forms of cult equipment connected with the palaces and major centers disappear, along with Linear A, and tombs reemerge as focal points for funerary cult, indicating that in some way the destructions mark a rejection of the Neopalatial religious system and a reemergence of long-held beliefs and customs. Historical parallels suggest that throughout the Neopalatial period, popular cults probably existed outside of palatial control alongside official cults.

The peak sanctuary on Juktas, in use in Protopalatial times, had its first major building program in MM II-III when megalithic terraces I and II were established around an altar used for burning, adjacent to a natural cleft into which debris was swept. ${ }^{360}$ Several offering tables or kernoi have been found built into the altar and set alongside the area of burning. A series of small subsidiary rooms was built against the slope on the east. After a MM III destruction, the sanctuary was reorganized and blocking walls subdivided the subsidiary rooms $\mathrm{I}-\mathrm{V}$, reusing poros blocks and a column base from the earlier phase. Neopalatial finds included stone offering tables and vessels, a fragment of a painted terracotta house model, anthropomorphic figurines, sheet bronze votive tools, scraps of gold foil, and sealstones. The open terraced areas and their formal approach ramp should be considered an example of a "sacred enclosure," not a temple or a tripartite shrine. A megalithic circuit wall enclosing the peak might be as early as MM III/LM I or as late as LM III.

Juktas was approached by at least one Minoan road from Knossos to the north. Along this route, just below the peak and outside the circuit wall, lay Building B, begun late in Protopalatial times (MM IIB-MM IIIA) and rebuilt along more impressive lines at the beginning of Neopalatial times (MM IIIA-B). Each phase ended in a destruction by fire. Because many of the finds are of a practical nature (e.g., a stone

${ }^{360}$ A. Karetsou, "The Peak Sanctuary of Mt. Juktas," in Sanctuaries 137-53; Karetsou, Prakt 1975, 330-42, esp. pl. 268 $\alpha-\beta$; Ergon 1975, 176-77; Ergon 1985, 83-87; Ergon 1988, 160-65; AR 33 (1987) 55; AR 35 (1989) 99; AR 36 (1990) 71; AR 41 (1995) 60; Archanes 10-22.

${ }^{361}$ Atlas 51-53; Archanes 137-56; Vallianou (supra n. 11) 153-67; Musgrave et al. (supra n. 13).

362 D. Hughes, Human Sacrifice in Ancient Greece (London 1991); P.M. Warren, AR 29 (1983) 63-87; S. Wall et al., "Human Bones from a Late Minoan IB House at Knossos," BSA water channel, a pottery workshop), this building may have served the sanctuary as a way station and man. ufactory for votive items.

Lower still and farther north along this route is the shrine building at Anemospilia, ${ }^{361}$ perhaps another station on the road up to Juktas. This building collapsed in an earthquake in MM IIIA, followed by fire, entombing four individuals; forensic reconstruc. tion of their faces provides important new evidence about Minoan physiognomy. There is no real evidence that human sacrifice was taking place here, although the recently discovered children's bones at Knossos in a LM IB context have been interpreted as evidence for ritual cannibalism. ${ }^{362}$

A mountainside (but not peak) sanctuary at Kato Syme forms an important comparison to Juktas, but unlike it, Syme seems to have existed outside any one direct palatial authority and to have served more than one geographic region. ${ }^{363}$ Located at an elevation of 1,200 masl in a natural concavity at the foot of a cliff on the south slope of Mt. Dikte, Syme's setting is reminiscent of that of Delphi. Integral features of the site were a perennial gushing spring of icecold water and a waterfall, both of which probably attracted the attention of the Minoans. Because of its relative inaccessibility, Syme can only have been used on a seasonal basis, and even now the site is inaccessible in winter. Minoan visitors from Central Crete probably took an overland "pilgrimage" route from the Mesara and Pediada up to modern Embaros on the southwest slope of Dikte; from there, one fork ascends east up to Omalos and over to Syme, and another fork leads north to Lasithi and the Diktaian Cave at Psychro.

Despite Kato Syme's complicated stratigraphy, two Protopalatial phases with impressive serpentine architectural elements have been identified. The center of the sanctuary was an open area where stone libation tables were set at the edges of small fires, recalling the arrangement at Juktas. Following a break after MM IIB, a reorganization of the peribolos took place with three recognizable Neopalatial phases. After the first of these, a paved road was constructed

\section{1 (1986) 333-38.}

363 We are grateful to A. Lembesi and P. Muhly for showing us the site in June 1996. Atlas 268-71; A. Lembesi, Prakt 1992, 211-30; Lembesi and Muhly (supra n. 125); A. Kanta, "Cult, Continuity and the Evidence of Pottery at the Sanctuary of Syme Viannou, Crete," in D. Musti et al. eds., La transizione dal miceneo all'alto arcaismo: Dal palazzo alla città (Rome 1991) 479-505; AR 36 (1990) 70; AR 37 (1991) 68; AR 38 (1992) 59. 
over a series of small subsidiary rooms, leading up to an enclosure that contained a large, well-built megalithic platform. Between the peribolos wall and interior platform were traces of burning, fragments of stone offering tables (a few inscribed in Linear A), and other equipment: tubular stands, chalices with plain surfaces or relief decoration, figurines, huge numbers of conical cups, cooking pots, and jars, and the burnt and cooked bones of animals (sheep, goats, deer) suggesting ritual dining but not holocausts. ${ }^{364}$ Later in the Neopalatial period, the construction of Building 5 covered part of the approach ramp. Although some fine bronze figurines have been found, the lack of "palatial" dedications is noteworthy in contrast to Juktas, and the most common finds are pottery-often specialized cooking shapes and drinking vessels. Other sacred enclosures with terraces existed elsewhere on Crete, at the peak sanctuary at Kophinas on the south coast ${ }^{365}$ and at Petsofa above Palaikastro.

Caves were also important, and a number of them show continuing use from MM II into LM I. ${ }^{366}$ There are Neopalatial deposits in the Diktaian Cave at Psychro on the north side of Mt. Dikte overlooking the Lasithi plain, the Arkalochori Cave in the Pediada plain, the Idaian Cave on Mt. Ida, and the cave of Eileithyia south of Amnisos at Episkopi. In all these locations, the finds include terracottas, along with bronze double axes and figurines. Much of the material deposited in caves is indistinguishable from the material dedicated at peak sanctuaries, and none of the locations can be distinguished from others on the basis of its finds, except for Arkalochori with its rich deposits of bronzes and precious metal double axes. This might mean that the same divinity was worshipped at each, or that offer-

\footnotetext{
${ }^{364}$ Lembesi and Muhly pointed out to us that there is no evidence for holocausts (as in later Greek religion), but they noted that the heads of some animals may have been placed at the edges of the fires.

${ }^{365} A R 42$ (1996) 45: the main period of use is MM IIILM I.

366 P. Faure, "Cavernes sacrées de la Crète antique," Cretan Studies 4 (1994) 77-83; B. Rutkowski and K. Nowicki, The Psychro Cave and Other Sacred Grottoes in Crete (Warsaw 1996); Watrous (supra n. 355); I.A. Sakellarakis, "The Idaean Cave," Kernos 1 (1988) 207-14; E.L. Tyree, Cretan Sa cred Caves (Diss. Univ. of Missouri-Columbia 1974). Individual caves: Mamelouka (Kanta 228-29; Tzedakis [supra n. 310]); Melidone cave, West Crete (AR 36 [1990] 80); Skales near Praisos (AR 37 [1991] 76); Diktaian Cave (J. Board. man, The Cretan Collection in Oxford [Oxford 1961]); Arka. lochori (S. Marinatos [supra n. 210]); Idaian Cave (I.A. Sa-

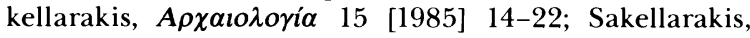

ings for one divinity were appropriate for another. Later Greek myth connects other caves with birthplaces and the cults of goddesses: Dikte and Ida, for example, are associated with the worship of the mother goddess, Rhea, and the birthplace of her son, Zeus, ${ }^{367}$ but it is not possible to push these last identifications convincingly back into the Bronze Age.

The origin of the horns of consecration is uncertain, but they do not at all resemble bulls' horns: an early (MM II) plaster model of composite horns found at Petsofa suggests that they had a longstanding connection with peak sanctuaries, and perhaps their resemblance to the Egyptian horizon sign is not accidental. ${ }^{368}$ Horns, when attached to architecture, thus seem to signpost buildings or areas where ritual could take place. Large stone horns were set up in the courtyard at Nirou Chani and near the north and south entrances to the palace at Knossos; half of an immense pair of gypsum horns is now located at the north end of the west court at Knossos near the Theatral Area. ${ }^{369}$ In some representations, however, buildings are crowned by horns or by small gonical projections that cannot be equated with horns of consecration.

At habitation sites, possible locations for ritual activity include paved courtyards, especially the central and west courts of the palaces, stepped "theatral areas," and in the interiors of buildings in or at lustral basins, pillar basements, and polythyra. ${ }^{370}$ Raised walkways suitable for processions or dances have been noted in courts at Knossos, Phaistos, Nirou Chani, Archanes Tourkogeitonia, and Pyrgos. ${ }^{371}$ The Knossos Sacred Grove and Dance Fresco shows gesticulating women in such a location, observed by male and female spectators. The Grandstand Fresco has been interpreted as showing a rit-

ArchEph 1987, 237-63; Sakellarakis 1988 [supra]).

367 Archanes 18-20. A.H. Griffiths, "Six Passages in Callimachus and the Anthology," BICS 17 (1970) 32-43, esp. 32-33; S. MacVeagh Thorne and A. Prent, "The Sanctuary of Diktaian Zeus at Palaikastro," 8th CretCong (forthcoming); G.A. Owens, "New Evidence for Minoan 'Demeter', Kadmos 35 (1996) 172-75.

368 A.L. D'Agata, "Late Minoan Crete and Horns of Con. secration," in Eikon 247-56; Davaras (supra n. 124) fig. 31; Gesell passim, figs. 71-79; T.F. Strasser, "Horns of Consecration or Rooftop Granaries?" in Techne 201-206; E. Gi

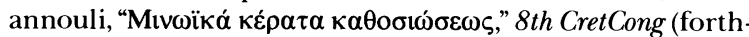
coming); A.J. Evans, Scripta Minoa (Oxford 1909) 223-24, sign $114=C H I C$ (supra n. 270) sign 34 .

369 PM II.2, 589 fig. 367 ; cf. the limestone horns now set up on the south side of the palace (PM II.1, 159 fig. 81, 160).

${ }^{370}$ Gesell passim, esp. 30.

${ }^{371}$ Davis (supra n. 173); Marinatos (supra n. 173). 
ual activity in the central court of the Knossos palace. The size and shape of the courtyards and theatral areas, and the large numbers of spectators of both genders in the Knossos frescoes, once again stress communal, not individual, activities. Small constructions in the west court at Knossos and in the central courts at Zakros, Mallia, and Galatas may have had a ritual function. Those in the central courts would have presented obstacles if the central courts really were used for the sport of bull-leaping.

The importance attached to architectural representation is reflected in the use of terracotta architectural models attested at a number of Protopalatial sites, including peak sanctuaries. Important examples date from the beginning of the Neopalatial period, like the models from the Loomweight Basement of the Knossos palace (traditionally MM II, but probably MM III), and funerary and domestic models from Kamilari. ${ }^{372}$ The house model from Archanes (MM IIIA context) is two-storied. The ground floor plan resembles that of Zakros House G; upstairs, three steps lead up to a small projecting balcony on the roof on which are preserved the feet of a terracotta figurine. A similar scene appears on the Miniature Fresco from the West House at Akrotiri where a woman stands at a balcony on the roof of a building. ${ }^{373}$ Another Neopalatial terracotta model (a house or a shrine?) was found at the peak sanctuary on Mt. Juktas.

The interior constructions identified as ritual areas are all, in some way, problematic. Lustral basins, small sunken chambers approached by a short flight of stairs, are first attested at Mallia in MM II with an example that is truly subterranean. ${ }^{374}$ Shallower examples proliferated early in the Neopalatial period and have been found at most of the palaces

\footnotetext{
372 Krattenmaker 1991 (supra n. 90); R. Hägg, "The Cretan Hut-Models," OpAth 18 (1990) 95-108; R. Mersereau, "Cretan Cylindrical Models," AJA 97 (1993) 1-47; Mersereau, AJA 96 (1992) 334 (abstract); I. Schoep, “'Home Sweet Home'. Some Comments on the So-Called House Models from the Prehellenic Aegean," OpAth 20 (1994) 189-210. Models from Knossos: PM I, 220 fig. 166. Kamilari: $P G C$ 101 no. 1223, pl. 1223; Marinatos (supra n. 97) figs. 21-23. Archanes: A. Lembesi, ArchEph 1976, 12-43 (dimensions:

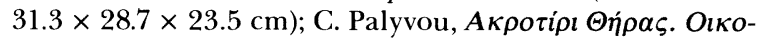

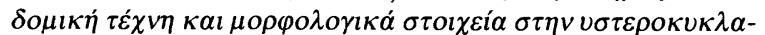
$\delta \iota \kappa \dot{~} \alpha \rho \chi \imath \tau \varepsilon \chi \tau o v \kappa \kappa \dot{~(D i s s . ~ N a t i o n a l ~ M e t s o b i o ~ P o l y t e c h n i c ~}$ Univ. 1988) pl. 89; Archanes 61 fig. 36 (color). Juktas: $A R$ 23 (1977) 63 fig. 100.

${ }^{373}$ Doumas pl. 48.

${ }^{374}$ We thank M. Schmid, architect at Mallia, who gave us a tour of Quartier Mu and the lustral basin, June 1996. For lustral basins in general, see A. Nordfeldt, "Residential
}

and many, but not all, of the villas. Since they have no drainage, they are clearly not baths, and many of them are provided with low balustrades over which spectators could view activities in the interior. The figural fresco decorating a lustral basin on Thera depicts young women associated with crocuses and blood; if these paintings relate to the use of the Thera basin and if the basin was used in the same way as the Cretan examples, they should all have some connection with female rites of passage. If this identification is correct, lustral basins shed important light on the function of Neopalatial palaces and villas and again underscore the importance of women in $\mathrm{Mi}$ noan society. Some lustral basins, including one at Chania painted with marbled decoration, had passed out of use before the end of the Neopalatial period, suggesting that the societal need for these rooms was changing. After the LM IB destructions, no more are built and existing ones are filled in.

Pillar basements are another regular feature of Neopalatial villas and palaces, where they are often located in the west wings. ${ }^{375}$ Although ritual objects often fell into pillar basements from upper floor rooms when the buildings were destroyed, ${ }^{376}$ the discovery of pithoi and drainage channels in many of the basements indicates clearly that they are primarily storerooms. Similarly, polythyra with pierand-door partitions are a regular feature of Neopalatial palaces and villas. ${ }^{377}$ The many openings permitted free flow of traffic, and the openings could be closed selectively to create privacy, but their ritual use is unproven and very little specialized equipment has ever been found in them. During LM IB, the openings between piers at many sites were closed off by partitions and built cupboards, sometimes for the storage of documents, suggesting that

Quarters and Lustral Basins," in Palaces 187-93. Gesell 22-26, for discussion and catalogue. For more recent work:

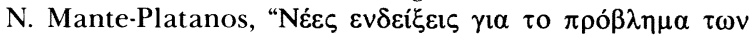

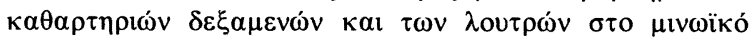

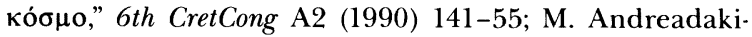
Vlasaki (supra n. 73); W.D. Niemeier, "On the Function of the 'Throne Room' in the Palace at Knossos," in Palaces 163-68, esp. 163-64 on various interpretations: bathrooms (Nordfeldt), imitations of cult caves (S. Marinatos), or as special rooms or adyta for sacrifices and offerings (N. Marinatos); L. Hitchcock, "The Best Laid Plans Go Astray: Modular (Ir)regularities in the 'Residential Quarters' at Phaistos," in Techne 243-50.

375 Gesell 26-29; E. Hallager, "A 'Harvest Festival Room' in the Minoan Palaces?" in Palaces 169-77; Begg 29-32.

376 Cf. Soles and Davaras 1994 (supra n. 33) 408-10.

377 Marinatos and Hägg (supra n. 84); Graham (supra n. 85); Driessen (supra n. 84); Hitchcock (supra n. 85). 
the use of the polythyron was also changing before the end of the Neopalatial period. It too disappears rapidly after the LM IB destructions.

Several types of architectural construction represented in frescoes, glyptic, and on stone vases are poorly represented in the archaeological record, notably the tripartite shrine (only surely attested in the west wing at Knossos), and constructions enclosing or adjoining "sacred trees," which seem to be portable since two are represented on ships. ${ }^{378}$ Four stone incurved bases found at Archanes Tourkogeitonia may have been used as supports for a temporary platform like those shown in paintings and on seals. Some representations of shrines have slender columns with floral heads, suggesting that such architecture could be set up quickly for specific events and then taken down. ${ }^{379}$ The portable nature of much other cult equipment may help explain why so little cult architecture has been found and rein. forces the notion that there were relatively few fixed locations for ritual.

There is evidence for a small house shrine at a number of sites, though the equipment differs in each. A possible shrine on the Royal Road at Knos$\operatorname{sos}^{380}$ included two tables of offerings, a small limestone horns of consecration, a fragment of an animalhead rhyton, and Special Palatial Tradition pottery. The shrine identified in the west wing of the Zakros palace is a figment: there is no direct connection between the room (which was devoid of special contents) and the workshops and storerooms with ritual equipment; as noted above, the latter rooms communicated instead with the large banqueting hall of the palace. At Knossos, several upper floor rooms have been identified as shrines on the basis of the frescoes that once adorned them, but proof of their ritual use is again lacking.

Special rocks, or baetyls, depicted on gold rings have been suggested as the seats of divinities or divine forces. ${ }^{381}$ In most of these representations, a

${ }^{378}$ Tripartite shrine: Shaw (supra n. 134). "Sacred trees": B. Rutkowski, "Der Baumkult in der Ägäis," Visible Religion 3 (1985) 159-71. C. Sourvinou-Inwood, "Boat, Tree and Shrine: The Mochlos Ring and the Makrygialos Seal," Kadmos 28 (1989) 97-101, on CMS II.3, no. 252, and CMS V, Suppl. 1A, no. 55, both from LM I contexts.

${ }_{379}$ E.g., on the Ayia Triada ivory pyxis, Halbherr et al. (supra n. 158); cf. the shrine on a fresco from Thera: Doumas pl. 147.

${ }^{380}$ Gesell 101, no. 64.

${ }^{381}$ P. Warren, "Of Baetyls," OpAth 18 (1990) 193-206; Younger 1988 (supra n. 106) 282-83; Renfrew et al. (supra n. 354) 430-31.

382 G.C. Gesell, “The Minoan Snake Tube," AJA 80 (1976) man or a woman kneels at the stone, sometimes gesturing. It is possible that these stones were located in sanctuaries like the possible omphalos at Phylakopi.

Many art objects have been identified as cultic or ritual equipment, not always on very solid grounds. Probable cult equipment includes stone kernoi (portable and fixed) and offering tables, stone ladles, clay and stone rhyta of specialized shapes and decoration, plastered and painted tripod tables, sea shells (real and of faience, or stone rhyta carved in the shape of tritons), and nonfunctional double axes, often elaborately engraved, which may have been used as votives or emblems. The recurring emphasis on sea imagery, particularly on Marine Style pottery, could mean that important activities took place at the shore or even in the water (cf. the Mochlos ring).

The various rhyton shapes made of stone, terracotta, and perhaps metal, along with conical cups, suggest that wine-drinking played an important role in cult activities. The distribution patterns of rhyta imply that most were manufactured at Knossos and perhaps disseminated from there to other sites. The possibly deliberate breakage of these objects has been discussed above. Tubular stands, the ancestors of the Final and Postpalatial "snake tubes," were meant to support open bowls, perhaps for offerings. ${ }^{382}$ Anthropomorphic and zoomorphic figurines were made of terracotta, bronze, or lead, presumably for use as votive objects.

Although bucrania are often represented in association with double axes, there is no certain evidence that animals were sacrificed before the Final Palatial period. There may therefore be an aspect to the association of the bucranium and ax that we do not yet understand. ${ }^{383}$ The double ax is combined with a loop-fillet, a frequent device on LM IB Alternating Style pottery. "Sacral knots" with fringed ends were sometimes manufactured in faience, painted on a wall at Nirou Chani, or carved of ivory. ${ }^{384}$

247-59.

383 E.g., a cushion seal from Knossos (CMS II.3, no. 11); a LM IB amphora from Pseira (Betancourt and Davaras [supra n. 21] 35-36, figs. 16 and 38, pl. 13). See I.A. Sakellarakis, "Das Kuppelgrab A von Archanes und das kretischmykenische Tieropferritual,” PZ 45 (1970) 135-219.

384 Pottery: e.g., $C M$ pls. 82 left, 83 lower right; Archanes 55 col. fig. 32; Cummer and Schofeld (supra n. 158) no. 1553, pl. 85; K. Demakopoulou ed., The Mycenaean World (Athens 1988) 105 no. 36 and col. fig. The Vapheio ring: CMS I, no. 219. Nirou Chani fresco: $P M$ II.1, 284 fig. 168; Gesell 192 fig. 90. Ivory from Knossos: PM I, 427 fig. 308; Gesell 192 fig. 87. 
Another possible religious symbol is the figureeight shield. ${ }^{385}$ Both the figure-eight and the tower shield had a functional use as body armor. But unlike the tower shield, the figure-eight shield appears in ways that suggest that it had a ritual symbolism as well. Repeating friezes of figure-eight shields appear on pots as early as LM IA, and in LM IB this shield is a regular element on Alternating Style pottery, including an unusual piece from the Cult Basement at Knossos, which contained the bones of children. The shield also appears as a jewelry pendant, and a Minoan silver rhyton in the shape of a figureeight shield comes from Mycenae Shaft Grave IV. The shield also appears on the LM I Vapheio ring (CMS I, no. 219).

The principal Minoan cult symbol, the double ax, occurs as a motif in a variety of media. ${ }^{386}$ While double axes can exist as functional tools, many examples survive made of thin bronze or precious metal, which could not possibly have been used for practical purposes. A fresco fragment from Knossos shows double axes attached to or embedded in columns that alternate with horns of consecration. Since the axes are portable, they could have been carried to the locations where they were needed, set in stone bases, and then removed after use. Since we never see the double ax being used as a sacrificial tool, the main function of the decorative examples may have been to demarcate the locations where ritual activities were to be performed.

Attempts to identify divinities or their representations are generally problematic. Most convincing is one iconographic topos: a large woman seated facing left on an architectural platform attended by women and/or animals. ${ }^{387}$ This topos appears on several seals and gold rings, and in fresco, especially in the large-scale fresco from Xeste 3 at Akrotiri. A frontal Mistress of Animals appears on some Neopalatial sealstones, wearing the "Snake Frame" head-

385 P. Rehak, "Minoan Vessels with Figure-Eight Shields," OpAth 19 (1992) 115-24. Add a vessel from Pseira: AR 38 (1992) 69.

386 E.g., a basket-vase from Pseira (Betancourt and Davaras [supra n. 21] 12, fig. 9); in relief on a pithos from Zakros (Prakt 1994, pl. 222 $\alpha$ ); ivories from Zakros (Zakros 131 fig.); a fresco from Knossos (M.A.S. Cameron and S. Hood, Sir Arthur Evans' Knossos Fresco Atlas [London 1967] pl. 5.1).

387 Younger (supra n. 257) 171-77, pls. LXIc, LXII (all), LXIIIa-c, LXIVa-b, LXVc-f, LXVIa-f.

388 Younger (supra n. 257) 182-83; R. Hägg and Y. Lindau, "The Minoan 'Snake Frame' Reconsidered," OpAth 15 (1984) 67-77; M.A.V. Gill, "The Minoan 'Frame' on an Egyptian Relief,” Kadmos 8 (1969) 85-102. dress and flanked by antithetic griffins or lions. ${ }^{388}$ The presence of antithetic griffins flanking the throne in a Final Palatial renovation of the Knossos throne room has been used to support the hypothesis that during the Neopalatial era a ruler or priestess occupied the throne in an epiphanic ritual. ${ }^{389}$ Recent discussion of the Final Palatial evidence for the throne room tends to obscure the fact that in the Neopalatial period the area combined a polythyron with a lustral basin. The three faience figurines from the Temple Repositories are sometimes claimed as snake goddesses, but a wide chronological gulf separates them from the Postpalatial terracotta figurines holding snakes.

Figures of women and men who hold one arm outstretched and grasp a staff or spear in the "com. manding gesture" have been called rulers or gods. ${ }^{390}$ The most likely to represent divinities are the small descending youth in this pose on a gold ring in the Ashmolean Museum and the woman in restored sealings from the area of a shrine on the west side of the central court at Knossos. ${ }^{391}$ In the Knossos seal. ings, the woman with the commanding gesture stands atop a mountain peak flanked by antithetic rampant lions; to one side is an architectural representation with horns of consecration, and on the other side is a standing male who salutes her. Despite the small size of the elevated figures, their identification as divinities is strengthened by the presence of a woman on the ring and a man on the sealings, both of whom bow their heads and hold a clenched fist at the brow, a pose known from bronze statuettes of figures presumed to be votaries. Opinion is divided over the man performing the commanding gesture on the Master Impression from Chania who stands atop a cityscape: he could be a ruler or a god..$^{392}$ Many other proposed divinities are ambiguous or doubtful. It is difficult to identify gods and rulers because no text labels them and no trait distinguishes one

\footnotetext{
389 S. Mirié, Das Thronraumareal des Palastes von Knossos (Bonn 1979); R. Hägg, "Epiphany in Minoan Ritual," BICS 30 (1983) 184-85; Hägg, "Die göttliche Epiphanie im minoischen Ritual," AM 101 (1986) 41-62; W.-D. Niemeier, "Zur Deutung des 'Thronraumes' im Palast von Knossos," $A M$ 101 (1986) 63-95; Niemeier (supra ns. 244, 374).

390 Younger (supra n. 257) 156-62; T. Corsten, "Zu den sogenannten Schwebenden Gottheiten," in E. Thomas ed., Forschungen zur ägäischen Vorgeschichte: Das Ende der mykenischen Welt (Cologne 1987) 193-200.

391 M.R. Popham and M.A.V. Gill, The Latest Sealings from the Palace and Houses at Knossos (Oxford 1995) 41, pls. 5 and 27 (KSPI M1-5).

392 E. Hallager, The Master Impression (SIMA 69, Göteborg 1985), on CMS V, Suppl. 1A, no. 142.
} 
from the other. This ambivalence underscores a fundamental difference between Neopalatial Crete and its neighboring civilizations of the eastern Mediterranean. In almost every culture, even those with documentary texts, the precise nature of the relation between god and ruler is problematic. ${ }^{393}$ Typically, rulers have claimed divinity in three ways-directly, rhetorically, or only on special occasions. If the seal that impressed the Master Impression was not a commemorative piece, it may reflect one of the first two relationships.

The evidence for cult statues is controversial. ${ }^{394}$ Although terracotta feet with pointed, upturned toes have sometimes been identified as the feet of statues, like the separate feet inserted into the skirts of terracotta figurines in LM III, they have been found more often singly than in pairs, starting in the Protopalatial period. ${ }^{395}$

The scholarly investigation of gender in Minoan religion and society has gotten off to a slow start, ${ }^{396}$ despite much popular discussion about the role of women on Crete. The deposition of male and female figurines at peak sanctuaries suggests that these locations were used by men and women, though perhaps at different times. Only two Neopalatial frescoes (the Grandstand and the Sacred Grove and Dance frescoes, both from Knossos) show men and women together, but the women are larger and more elaborately dressed. In contrast to stone relief vases, where only men appear, women and animals like agrimia and blue monkeys are shown in nature scenes in frescoes and in glyptic, and there are repeated references to flowering plants like crocuses and lilies, which have medicinal properties. These gendered scenes suggest a culture/nature dichotomy

${ }^{393}$ H. Frankfort, Kingship and the Gods (Chicago 1948); J. Baines, "Kingship, Definition of Culture, and Legitima. tion," in D. O'Connor and D.P. Silverman eds., Ancient Egyp. tian Kingship (Leiden 1995) 3-47; D. Cannadine, in D. Cannadine and S. Price eds., Rituals of Royalty (Cambridge 1987) 1-19; D.A. Freidel and L. Schele, "Kingship in the Late Preclassic Maya Lowlands," American Anthropologist 90 (1988) 547-67; R. Garland, "Priests and Power in Classical Athens," in M. Beard and J. North eds., Pagan Priests (London 1990) 75-91; S. Houston and D. Stuart, "Of Gods, Glyphs, and Kings," Antiquity 70 (1996) 289-312, esp. 290; D. Kertzer, Ritual, Politics, and Power (New Haven 1988); C. Geertz, "Centers, Kings and Charisma," in J. Ben-David and T.N. Clark eds., Culture and Its Creators (Chicago 1977) 150-71.

${ }^{394}$ N. Marinatos and R. Hägg, "Anthropomorphic Cult Images in Minoan Crete?" in Society 185-201; I.B. Romano, "Early Greek Cult Images and Cult Practices," in R. Hägg, N. Marinatos, and G.C. Nordquist eds., Early Greek Cult Prac. tice (Stockholm 1988) 127-34.

395 B. Forsén and J. Forsén, "A Prehistoric Foot from Ar- rather than an innate interest in nature on the part of the Minoans. ${ }^{397}$ The only ritual activity that seems to include both women and men as participants is bull-leaping.

The use of wine seems to have played an important part in religious activities, including feasting, drinking ceremonies, and exchange systems among the palatial elite. One of the calcite Thera chalices was found with a miniature Minoan wine vat of the same material, suggesting a connection; the Vapheio ring depicts a large pithos at one side of the cult scene; and the wine pithos found in a country house at Epano Zakros has a Linear A inscription around its rim recording a huge quantity of wine, 32 units (921.6 l). Several installations for producing wine have been found in buildings with palatial features and fresco decoration. Finally, a number of rhyta and other vessels may have been used in drinking, along with the stone chalices found at various sites, the clay chalices from Kato Syme, and the ubiquitous conical cups. The archaeological evidence for the Minoan use of wine, and the depiction in fresco and glyptic of figures in exaggerated movement have led some scholars to postulate the existence of ecstatic religion. ${ }^{398}$

In summary, during the Neopalatial period religion seems to have been used by the palaces and villas to support a political system in which the ruling class may also have been religious officials. The lack of identifiable cult buildings, the creation of open areas that could accommodate gatherings of people, and the portable nature of most Minoan cult equipment suggest that an essential aspect of Neopalatial religion was its theatrical or performative nature. Minoan social and perhaps political organi-

golis," Journal of Prehistoric Religion 6 (1992) 24-29. Single feet: Gournia, Sklavokambos, Phaistos; add Chania (Tzedakis and Hallager [supra n. 50] 15 fig. 14) and Mochlos (Soles and Davaras 1994 [supra n. 33] 419, 420 fig. 16). Pairs of feet: Mallia (Protopalatial) and Anemospilia (early Neopalatial). Five different single feet come from Ayia Irini: Caskey, in Sanctuaries 134 fig. 10, and discussion, 136.

396 T. Cullen, "Contributions to Feminism in Archaeology," AJA 100 (1996) 409-14; D. Kokkinidou and M. Niko-

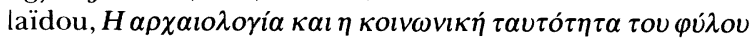
(Salonika 1993); S. Brown, "Feminist Research in Archaeol. ogy," in N.S. Rabinowitz and A. Richelin eds., Feminist Theory and the Classics (New York 1993) 238-71.

${ }^{397}$ S.B. Ortner, "Is Female to Male as Nature Is to Culture?" Feminist Studies 1 (1972) 5-21. P. Rehak and R.R. Snihurowych, "Medicine, Myth and Matriarchy in the Thera Frescoes," forthcoming in American Philological Association Abstracts of the 129th Annual Meeting (New York 1997).

398 P. Warren, "Minoan Crete and Ecstatic Religion," in Sanctuaries 155-66. 
zation may thus have been based on public action that merged religion and ceremony. If so, the $\mathrm{Mi}$ noans were in good company, since this type of performative religion as an aspect of politics was well established in Egypt and the Near East, and examples continue in some parts of the world today. ${ }^{399}$

\section{LM IB Destructions}

Toward the end of the LM IB period, there is evidence for significant disruptions at a number of Minoan sites throughout Crete and at heavily Minoanized sites in the Cyclades. At many locations, abandonment follows burning, and in many cases there is little sign of resettlement until LM IIIA1-2. The destructions thus mark a much more significant interruption of Minoan culture than those in MM II that signaled the end of the Protopalatial period. Major destructions are recorded at Chania and Nerokourou in the west; Phaistos and Ayia Triada in the south; Mochlos, Gournia, Pseira, Pyrgos, Makriyialos, Petras, Palaikastro, and Zakros in the east; and Zominthos, Sklavokambos, Tylissos, the Knossos area, Archanes Tourkogeitonia, Amnisos, Nirou Chani, and Mallia in Central Crete. At Knossos, the palace is unique in having no identifiable LM IB destruction deposits, but several buildings in the surrounding community were damaged or destroyed: the Stratigraphic Museum area (including the so-called Cult Basement) and structures along the Royal Road.400

These destructions appear selective and carefully planned to destroy as many administrative centers as possible. Settlements, and specific buildings that housed Linear A administrations, are particularly badly hit, so much so that they seem occasionally to have been deliberate targets: at Pyrgos, the villa was burned, but not the surrounding town; at Mochlos, ashlar Building B2 was destroyed, but not the artisans quarter, which continued into LM II;401 and Kommos escaped a major destruction, though House $\mathrm{X}$ yielded limited evidence of LM IB burning.

${ }^{399}$ C. Geertz, Negara (Princeton 1980) 98-120. We thank M. Nikolaïdou for mentioning this work on AegeaNet, 12 March 1996 (AegeaNet archive no. 960312.06).

${ }^{400}$ The Stratigraphic Museum area: P. Warren, AR 27 (1981) 73-92; and $A R 29$ (1983) 63-87. The Royal Road: $A R 7$ (1961) 26-27; AR 8 (1962) 25-27.

${ }^{401}$ J.S. Soles, "A Community of Craft Specialists at Mochlos," in Techne 425-31.

${ }^{402}$ S. Hood, "Warlike Destruction in Crete c. 1450 B.C.," 5th CretCong (1985) 170-78; Hood (supra n. 30); Popham and Catling (supra n. 236) 252-57.

${ }^{403}$ Fragments of the Palaikastro ivory youth were found strewn within and outside Building 5 . At Ayia Triada, six fragments of the Boxer Rhyton were found at ground level in the courtyard of Villa $\mathrm{A}$, while nine other fragments
The causes of the Cretan and Cycladic destructions have not been determined to the satisfaction of all scholars, although three main interpretations have been advanced: natural causes such as earthquakes followed by fire, invasion by mainland Mycenaeans, or a Knossian takeover of the rest of the island..$^{402}$ Several earlier attempts had been made to link the LM IB Cretan destructions with the IA Thera eruption; this position has now been abandoned by virtually all scholars. In any case, the conflagrations on Crete were so widespread that it is hard to attribute them to a single natural occurrence like earthquakes.

If the destructions are the work of Mycenaean invaders from the mainland, Knossos must have been spared, perhaps to serve as a base of operations against the other Minoan palaces and administrative centers, with the exception of a few key places like Kommos. Such a Mycenaean military intervention might explain the deliberately buried hoards of bronzes at Knossos and Mochlos and the signs of violent death (unburied bodies at Mochlos and defleshed children's bones at Knossos, possibly from siege conditions) and looting. ${ }^{403}$ Following the destructions, during LM II-IIIA1, new features appear on Crete that are similar to contemporary develop. ments on the mainland, though it is doubtful that there was an active Mycenaean colonization of Crete at this time. ${ }^{404}$ The military hypothesis also best explains the concentration of new features in and around Knossos. Perhaps the Mycenaeans collaborated with the Knossians or even were invited into Crete by them. If LM IB Knossos was primarily a religious center, it may have been spared on those grounds. Alternatively, the wealth of Knossos and the presence of so many important workshops there may have made it too valuable to be destroyed.

An alternative hypothesis of interstate warfare on Crete, without a Mycenaean component, could account equally well for many of the arguments listed above. The introduction of Mycenaean features could have taken place without a military conquest, and

were found higher up in the Cortile Superiore. The fragments of the Zakros Sanctuary Rhyton were found widely scattered throughout the palace. House AF N at Pseira showed signs of looting: AR 38 (1992) 68.

${ }^{404}$ M.R. Popham, "Mycenaean-Minoan Relations between 1450 and 1400 B.C.," BICS 23 (1976) 119-21 lists "intrusive mainland" features: chamber tombs with long "keyhole" dromoi, tholos tombs, "warrior burials" and "burials with bronzes," certain types of bronze vessels, utensils, tools, weapons and armor, specific types of jewelry, and specific ceramic shapes and decoration. Popham also notes changes in frescoes, stone vases, religion, architecture, writing, larnakes, and ivories. For a skeptical view of Mycenaean colonization, see H.W. Catling, Some Problems in Aegean Prehistory c. 1450-1380 BC (Oxford 1989). 
the militarism often imputed to the mainlanders is part of a general trend in the Aegean in the early part of the Late Bronze Age; it does not appear suddenly with the LM IB destructions and their aftermath. In searching for an agent of destruction, the obvious question is "cui bono"? Since the Knossos area survives relatively unscathed, some scholars have suggested that the destructions mark a Knossian takeover of the rest of the island centers. ${ }^{405}$ But it is hard then to explain the destructions at nearby Archanes, Tylissos, and Sklavokambos, all of which were presumably within the Knossian orbit at the time they were destroyed. Moreover, sites that were receiving leather documents sealed and impressed by Knossian look-alike gold rings are also destroyed: Chania, Sklavokambos, Ayia Triada, Gournia, and Zakros.

The destruction of administrative sites and elite objects could even be read in Marxist terms as a rejection by an underclass of a ruling elite and its trappings. The eruption of Thera could have caused crop failure in East Crete, which could have destabilized the economy of the island and led to a dissatisfaction with the existing palatial system. It is also possible to imagine a combination of factors, such as a Knossian takeover of the rest of the island with the help of Mycenaeans, some of whom stayed on the island and introduced new features.

All assessments of the nature and intensity of the LM IB destructions on Crete, however, have been modified in recent years by the recognition that many sites show evidence of destructions throughout the Neopalatial period, including LM IA. In addition, there is some disagreement whether the Cretan LM IB destructions are all contemporary or not: perhaps what looks to us like a single horizon may actually have taken place over years or decades.

Whatever their causes, the destructions unquestionably signal a major disruption in Minoan culture and a rejection of many of the features we think of as characteristic of Neopalatial society and its symbolic language. With the losses come new features, some of which we characterize as Mycenaean, leading us to prefer a scenario that includes some Mycenaean involvement. Some crafts survive, but we can document an immediate loss of decorative detail and a gradual decline in quality in the manufacture of decorated weapons, sheet bronze vessels, gold and silver plate, ivory carving for furniture and toilet implements, and stone vases. In hard stone seals, the decline occurs gradually over several generations.

405 W.D. Niemeier, "The Character of the Knossian Palace Society in the Second Half of the Fifteenth Century B.C.: Mycenaean or Minoan?" in Society 217-36.

${ }^{406}$ P. Rehak, "Aegean Art before and after the LM IB Cretan Destructions," in Techne 51-66.
The losses in art and culture, however, are immense, and even a partial catalogue is staggering: Linear A, court-centered buildings, lustral basins, polythyra, stone relief rhyta, stone lion's and bull's head rhyta, stone chalices and maces, niello daggers, relief frescoes, and three-dimensional figures in faience and ivory. ${ }^{406}$ There is an end to experimentation in rendering the human figure, an end to work in exotic materials, a divorce between writing and art, and the disappearance of major iconographic themes such as marine motifs, enthroned women, and landscapes with women and animals. This last loss we feel is significant. The gendered dichotomy between the scenes involving men in fairly restricted activities and the natural landscapes that include animals and women is replaced in Final Palatial art with recurrent scenes of men, processions of men and women, and the constructed world.

The losses in Neopalatial art and culture must reflect the subsequent preferences in the Final Palatial period. For example, Mycenaean religion apparently made little use of peak sanctuaries or caves, and so there was no need for the types of objects that portrayed them or had been dedicated there. Instead, the succeeding art forms - terracotta figurines, pictorial pottery, mass-produced jewelry, flat wall painting - and the prevalence of tholoi all express different cultural values and constructions of political power. The Neopalatial period on Crete represented a high point in Aegean culture that would not be reached again.

\section{FINAL PALATIAL CRETE (LM II-IIIB EARLY)}

As we stressed at the beginning of this review, the designation "Postpalatial" for the period on Crete following the LM IB destructions is no longer adequate, for it is clear that the Knossos palace survived and continued to function as an administrative center well after LM IB, and that Linear B was in use early in LM IIIB at Chania, and probably at Knossos too. With Linear B tablets being written at least at two major sites after LM IB, "monopalatial" does not accurately describe the period either. ${ }^{407}$ After LM IIIB early there is no evidence for writing in Crete or for any centralized administration; the period LM II-IIIB early, therefore, may be termed Final Palatial. Thus Crete contrasts with the mainland, where we know that some palatial administrations continued to exist until the IIIB/C transition.

LM II represents the immediate aftermath of the

${ }^{407}$ For important studies of this period, see Kanta; M.R. Popham, "Late Minoan II to the End of the Bronze Age," in Evely et al. (supra n. 1) 89-102; Niemeier (supra n. 405) with a useful summary of opinions; Catling (supra n. 404); and Bennet (supra n. 292). 
Cretan destructions, and is a time of severe disruption at most centers: some sites were abandoned, others depopulated, and only Knossos shows sure signs of operating on a large scale, including the continued creation of a number of specialized products. LM II may have seen a Knossian reestablishment of its control at other sites and may have been the first period of Mycenaeanization of the island. ${ }^{408}$ On the mainland, palaces seem to have begun emerging at this time, notably the Menelaion near Sparta. ${ }^{409}$

In LM IIIA, signs of recovery and reoccupation are seen at many sites on Crete, though most settlements are smaller and less urbanized than their Neopalatial predecessors. New types of burials are introduced and there is a noticeable change in material culture. At Knossos, a destruction is documented at the transition from LM IIIA1 to 2 that is not mirrored at most other sites, where recovery continues relatively smoothly into LM IIIB early. In pottery, the distinguished Chania workshop ${ }^{410}$ begins production in LM IIIA and by LM IIIA2 local pottery centers are known at Palaikastro and perhaps Episkopi. There is no discernible break between LM IIIA1 and 2 pottery, and existing trends continue on into IIIB early. While LM IIIA pottery is found abroad, especially in Cyprus, it is overshadowed by Mycenaean pottery exported in bulk. Nonetheless, Crete is not at all out of contact with the Near East.

The IIIA1-2 interruption at Knossos is fraught with problems of interpretation; we give a summary here of opinions presented in more detail below. Several scholars who think that the Mycenaeans arrived at the time of the LM IB destructions believe that the Knossos palace no longer functioned after the IIIA1-2 break; they would date the Linear B tablets at the site to this horizon. Others have argued instead that the IIIA1-2 transition marks the first major arrival of Mycenaeans on Crete, and would date

408 LM II pottery has been found across the island. Bennet (supra n. 292) 244: the sites with LM II “may reflect the initial stages of the Knossian administrative system after the LM IB disturbances," i.e., as second-order [palace] sites within a "new administrative system."

409 Watrous (supra n. 1) 796; Shelmerdine (supra n. 16) 559.

${ }^{410} \mathrm{Y}$. Tzedakis, "L'atelier de céramique post-palatiale à Kydonia, BCH 93 (1969) 296-418; Demakopoulou (supra n. 384) 147, no. 103 (color illustration).

411 Praisos, Achladia, and Piskokephalo are reoccupied in LM IIIA2: J. Bennet, "The Wild Country East of Dikte," Minos 20-22 (1987) 77-88, esp. 85. Pseira (Betancourt and Davaras 1995 [supra n. 21] 69; and in Cretan Studies [supra n. 34] 35) and Zakros (Kanta 195) show slight reoccupation the Knossos tablets to the last phase of Final Palatial at the site (IIIA2-IIIB early). We follow a mix of these two scenarios: Linear B was probably being written at Knossos in IIIA1 but the final administrative activity probably belongs to IIIA2-B early. Whatever its causes, however, the IIIA1-2 transition is significant because it ends Knossos's longstanding role as premier administrative and artistic center in the Aegean, and marks the dissolution and scattering of its workshops and workshop personnel. In this last phase of Final Palatial we can see evidence of a permanent change in Minoan art, the culmination of forces that had been in operation since the LM IB destructions. The following period, LM IIIA2-B early, is marked by the Linear $B$ tablets at Chania and the inscribed stirrup jars (ISJs) at many sites. The Final Palatial period ends with another destruction at Knossos and perhaps at Chania. Thus, the Final Pa. latial, like the Neopalatial period, cannot be regarded as a single monolithic entity.

\section{Sites and Architecture}

A few sites have uninterrupted occupation from LM IB to LM II; while most are destroyed and abandoned in LM IB, some are reoccupied in LM IIIA1, others in IIIA2. ${ }^{411}$ The overall population appears to have declined significantly by LM IIIB, especially in East Crete, although this trend toward depopulation had already begun in some places in LM IB. In the west, Chania was hard hit but began to recover immediately: squatters cleared some of the settle ment in LM II. ${ }^{412}$ After a destruction by fire at the end of LM IIIA1, there was a short abandonment. In LM IIIA2-B early, reoccupation resulted in two building complexes, Houses I and II, making use of the orientation of some earlier walls. New features, however, suggest the presence of Mycenaeans: poorly constructed rubble walls, single-story buildings (no stairs and no material fallen from above), circular

in LM IIIA2. Kastelli Pediados may be occupied at the very end of the Final Palatial period and continue into Post palatial (AR 36 [1990] 72). Along with these later sites are later cemeteries that continue into the Postpalatial period.

412 B.P. Hallager, "Some LM IIIB:1 Floor Deposits at Khania (summary)," in Schiering (supra n. 114) 89; B.P. Hallager, "Mycenaean Pottery in LM IIIA1 Deposits at Khania," in French and Wardle (supra n. 36) 173-83; B.P. Hallager, "LM II and Khania," 6th CretCong A2 (1990) 77-83; E. Hallager, "The Late Minoan III A2 and III B Periods in Khania," in Schiering (supra n. 114) 88; E. Hallager, "Khania and Crete ca. 1375-1200 B.C.," Cretan Studies 1 (1988) 115-24; Y. Tzedakis, "The Late Minoan III Settlement of Kydonia," BICS 20 (1973) 154-56. 
hearths fixed in the center of major rooms, and local and imported figurines of types known in the Argolid, many placed near the hearth.

In the south, the Mesara plain continued to be an important area. ${ }^{413}$ At Ayia Triada, in LM IIIA1 the impressive Megaron is erected, and in LM IIIA2 there is much building activity. The Megaron has enormous cyclopean foundations sunk several meters deep through the remains of the Neopalatial villa, and stone drainage channels were cut to draw runoff water away from the building. ${ }^{414}$ Although the Megaron's superstructure has not survived, the dimensions of the foundations indicate a building larger than any of the surviving mainland megara. Adjacent to this building to the east was a small stoa, with a large and impressive second stoa to the northeast, the so-called Agora. Building W, of IIIA2 date, delimits another side of the Agora, along with buildings on the slope to the west. There is evidence for two shrines, one west of the Agora and one to the southeast of the Megaron. Judging by architectural remains alone, Ayia Triada was a major administrative center, even though no Linear B tablets have been recovered there.

With much imported pottery from the Near East and Italy, the port at Kommos flourished from the Neopalatial period through LM II into IIIA, but was almost completely abandoned at the end of IIIB early. In IIIA2, a series of shipsheds (Building P) was constructed over the east wing of Neopalatial Building $T$. The masonry of this building reused Neopalatial ashlar blocks, but they were set in a new way with small stones in the horizontal and vertical joints, a style of Final Palatial architecture seen at many other sites on Crete.

At Gournia, the ruined LM IB "palace" seems to have remained deserted, but in LM IIIA a megaronlike structure was inserted into the community at the south end of the plateia, on a different orien-

\footnotetext{
413 Phaistos exhibits limited reoccupation, mostly houses (Kanta 96-101). The stepped construction in the northwest corner of the central court could be Final Palatial as well as the pithoi there (Atlas 235).

${ }^{414}$ V. La Rosa, "Haghia Triadha in età micenea," in J.P. Olivier ed., Mykenaïka (Paris 1992) 617-20; La Rosa, "Osservazioni sul centro di Aghia Triadha in età TM IIIB-C," in Rocchetti (supra n. 7) 75-80; B.J. Hayden, "Crete in Transition: LM IIIA-IIIB Architecture," SMEA 26 (1987) 199-234; D. Preziosi, "Mainland-Type Megara in Crete and the Cyclades during LM III," AJA 74 (1970) 201; Preziosi (supra n. 47) 175-93; K. Schaar, "Aegean House Form," in Darcque and Treuil (supra n. 3) 173-82; AR 36 (1990) 70-71; $A R 38$ (1992) 59. See also Niemeier, in SMEA (supra n. 5) n. 430, based on La Rosa, "Nuovi indagini ad Haghia Tri-
}

tation from the Neopalatial structures. ${ }^{415}$ At Mochlos, a few new structures were built in LM IIIA2 making use of the earlier Neopalatial buildings; remodeled, they continued in use into IIIB. At the east end of the site, a LM III cobbled road has been traced. Palaikastro had extensive IIIAl reoccupation, and two wells dug through the earlier Building 7 were in use the entire IIIA period.

North-central Crete follows, in general, much the same pattern as elsewhere. Tylissos, mentioned in the Knossos tablets, must have been an important Final Palatial center though the excavated LM IIIA architecture is scrappy. ${ }^{416}$ Simple house plans, a short stoa, and a circular cistern, like those at Archanes, Amnisos, and Zakros, are among the innovations. Recent excavations at Quartier Nu at Mallia have revealed new features: a megaron with a fixed hearth flanked by two columns, a room with a rare pebble mosaic, and stirrup jars inscribed in Linear B. ${ }^{417}$ At Archanes Tourkogeitonia, much of the Neopalatial building lay in ruins, but foundation walls associated with LM IIIA-B pottery were dug deeply into the west side of the building.

As noted above, the only Minoan site that seems to have flourished uninterruptedly and on a large scale is Knossos. ${ }^{418}$ Both the palace and its dependencies, the Little Palace, Unexplored Mansion, and Royal Villa, show continuous occupation into LM IIIB. Another important sign of continuity is the erection of a LM II house (not yet published) south of the palace that uses gypsum and includes a polythyron, an important indicator that the LM IB destructions did not mark a complete break with earlier building practices. A megaron-type structure may also have been inserted into the palace at the south end of the west wing, but so little evidence has survived that its existence is largely conjectural. ${ }^{419}$ The size of the community, however, may have shrunk since no other buildings occur on the hillside west

\footnotetext{
ada," 5th CretCong (1985) 190-98.

${ }^{415}$ F. Oelmann, "Ein archäisches Herrenhaus auf Kreta," JdI 27 (1912) 38-51.

${ }^{416}$ B. Hayden, The Development of Cretan Architecture from the LM IIIA through the Geometric Periods (Diss. Univ. of Pennsylvania 1981); and Hayden, "Late Bronze Age Tylissos," $E x$ pedition $26: 3$ (1984) 37-46.

${ }^{417}$ AR 36 (1990) 74-75; AR 37 (1991) 73-74; AR 38 (1992) 64-65; J. Driessen, “La Crète mycénienne," DossPar 195 (1994) 70-78. Cf. the pebble mosaic from Tiryns (LH IIIA): O. Pelon, in $B C H 109$ (1985) 776: "une mosaïque de galets à décor spiraloïde découvert dans la pièce XXII."

${ }^{418}$ D. Doxey, "Causes and Effects of the Fall of Knossos in 1375 B.C.," OJA 6 (1987) 301-24.

${ }^{419}$ PM II.2, 6-7.
} 
of the palace, except for the two stone-bordered circular "dancing" platforms constructed in LM II-IIIA and excavated near the Stratigraphical Museum. ${ }^{420}$

In recent years, a restudy of the Little Palace and the excavation of its "villa annex," the Unexplored Mansion, have shed important new light on Knossos in LM II-IIIA. ${ }^{421}$ Both are Neopalatial buildings, but the latter may not have been completed at the time of the IB destructions, since the floor of its pillar basement had not been laid. The building was occupied in LM II, although after one of several destructions in this period the south half of the structure was filled with debris and went unused while the north half continued to be occupied into LM IIIA and early B. At the same time there were modifications in the Little Palace, including blocking up the polythyron.

Within the palace there is evidence for continuous use and architectural modification through LM IIIA and into IIIB. While the east wing underwent some modifications, including blocked walls, and was eventually destroyed at least in part by fire, the west wing, which also was rebuilt, eventually collapsed. ${ }^{422}$ Especially important are the architectural modifications datable to LM IIIA2-B early. ${ }^{423}$ These include new paving in the central court, the final arrangement of the throne room, and rearrangements in the west magazines. In the area of the South Basements, pits of plaster may attest to the same general construction efforts. ${ }^{424}$

\section{Tombs and Burials}

In the period after the LM IB destructions new cemeteries with new types of burials are established

420 Warren 1983 (supra n. 400) 69. Some of the blocks of the surrounds have mason's marks, making them some of the latest examples, if they are not reused; see Driessen (supra n. 417) 75 for col. ill.

421 Popham et al. (supra n. 5); Hitchcock and Preziosi (supra n. 49).

422 Begg 201. We are grateful to P. Kienzle for allowing us to cite his message on AegeaNet, 15 February 1997 (AegeaNet archive no. 970215.06): “The Magazines are destroyed by fire" with fill equal to two stories. "In the Domestic Quar. ter there are no burn marks" with fill equal to six stories.

${ }^{423}$ LM IIIA2 pottery has been found beneath the central court pavers and the throne room floor: Cameron (supra n. 182); Niemeier (supra n. 374) esp. 163, 167. Begg 167-75: in the west wing, after a fire in IIIA2 that ignited oil in magazine 12 and blackened the gypsum revetments added throughout the west magazines, there is major architectural remodeling; early IIIA 2 sherds were found and fragments of a LM IIIA cup from magazine 13, cist 7, joined sherds from cist B4 in the Long Gallery; at the South Propylaeum, the remodeling of the west pier incorporated IIIA 2 and B material, the IIIA2 sherds joining sherds from magazines 8 and 18 . in different parts of the island. Among these are Warrior Graves at Knossos, Archanes, Phaistos, and Chania, similar in form and contents to contemporary Warrior Graves on the mainland; ${ }^{425}$ chamber tombs, approached by a short dromos; "shaft graves" slightly different in form from those of earlier date at Mycenae; pit caves; and tholoi whose keyholeshaped dromoi incline at the top.

Near Knossos, several cemeteries were in use in the Final Palatial period on the hills flanking the Kairatos stream north of the palace. The Mavro Spelio cemetery on Ailias, east of the palace, was already in use in Neopalatial times. Farther north, on the west, is the Zapher Papoura cemetery established in LM II-IIIA1 and the contemporary scatter of tombs toward Ayios Ioannes and the New Hospital. Continuing up the Kairatos is first the small group of five LM IIIA1-2 tombs at Sellopoulo, and finally the Isopata cemetery with a number of graves including the Royal Tomb. Near the mouth of the Kairatos at Katsamba on the coast is a series of rich tombs that began to be used in LM II. ${ }^{426}$

It is generally assumed that the Katsamba, Zapher Papoura, and Sellopoulo tombs belonged to Mycenaean communities established at this time. Although it is difficult to determine ethnicity from grave goods or grave forms, many of the Katsamba tombs included Palace Style jars, just as many mainland tholoi had during LH IIA. Some graves in these and other cemeteries exhibit what seem to be other Mycenaean features: the practice of burying select individuals with important sets of bronze vessels; ${ }^{427}$ and burials on biers or beds or in wooden coffins painted blue, yellow, or red.

${ }^{424}$ N. Momigliano and S. Hood, BSA 89 (1994) 103-50

${ }^{425}$ Evans (supra ns. 148, 240); Alexiou (supra n. 158); M.S.F. Hood, "Another Warrior Grave at Ayios Ioannis near Knossos," BSA 51 (1956) 81-103; Hood, "A Minoan ShaftGrave on the Slopes opposite the Temple Tomb," BSA 53-54 (1958-1959) 281-82; Hood, "A Minoan Shaft-Grave in the Bank with Hogarth's Tombs," BSA 53-54 (1958-1959) 283-84; Hood and P. De Jong, "Late Minoan Warrior Graves from Ayios Ioannis,” BSA 47 (1952) 243-77; S. Hood, G. Huxley, and N. Sandars, "A Minoan Cemetery on Upper Gypsades," BSA 53-54 (1958-1959) 194-262; Popham and Catling (supra n. 236). For Sellopoulo tombs 1 and 2, see AR 3 (1957) 24-25.

${ }^{426}$ Alexiou (supra n. 158); BCH 79 (1955) 295-96, fig. 6.

${ }^{427}$ The practice occurs first in the Shaft Graves of My. cenae Circle A, especially SG IV. See A.B. Knapp, "Hoards d'Oeuvres: Of Metals and Men on Bronze Age Cyprus," OJA 7 (1988) 149-50; Knapp et al. (supra n. 210); Matthäus (supra n. 225). Other burials with bronzes in Crete: Archanes Phourni, Tholos A and Grave Enclosure, shaft 4; Chania, tomb near the Law Courts (E. Karantzali, $B C H 110$ [1986] 53-87); Kalyvia, Tombe dei Nobili no. 8 (MonAnt 14 [1904] 533-34); Phylaki Apokoronou tholos (Y. Tzedakis, ArchDelt 
At Archanes Phourni, to the north and south of the Protopalatial and Neopalatial cemetery, new tombs are constructed: to the north, a group of Warrior Graves in a rectangular enclosure with plain stelae and the small tholos A are added in LM IIIA1-2; to the south, another small tholos, D, was inserted at the beginning of IIIA2. ${ }^{428}$ Burials, however, continued to be made in the funerary building 3 , whose earliest contents date to the Protopalatial period.

An untouched LM IIIA2 larnax burial, a rich woman of high status, was found in the side chamber of Tholos A. Her jewelry includes four gold signet rings with religious iconography, one a Neopalatial heirloom. Of the three smaller gold cult rings, two feature friezes of figure-eight shields, while the third carries a double frieze of shields alternating with sacral knots. On the chamber floor were various offerings, including a necklace of blue glass beads and two gold rings, and, in front of the larnax, an ivory footstool decorated with images of warrior's heads and figure-eight shields. In a corner of the chamber was a full set of bronze vessels like those found in contemporary male Warrior Graves. The entrance to the chamber had been walled up, but in the fill was a hornless bull's skull, and just outside the doorway, on the floor of the tholos, was the carefully piled heap of a butchered horse. The deceased may have had both administrative and religious functions, possibly connected with the Juktas peak sanctuary nearby.

Sites in western Crete are also rich in the number and quality of burials. At Armenoi, on the upland plain immediately south of Rethymnon, a large new cemetery was established in LM II. ${ }^{429}$ The earliest tomb is underground and corbeled like a tholos. More than 200 rock-cut chamber tombs date to LM IIIA1-B, and several were marked by stone stelae,

36 B2, Chronika [1981] 398-99; BCH 106 [1982] 628-30; L. Godart and Y. Tzedakis, Témoignages archéologiques et épigraphiques en Crète occidentale du Néolithique au Minoen Récent III $B$ [Rome 1992] 59-60, pls. LIV-LVII; $A R 28$ [1982] 58); Sellopoulo tomb 4 (Popham and Catling [supra n. 236]).

${ }^{428}$ Archanes Phourni: Atlas 54-58; Sakellarakis and Sakellaraki (supra n. 41); Archanes 66-135.

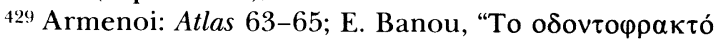

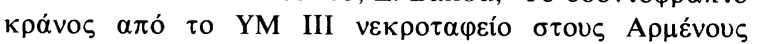

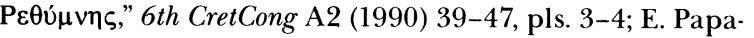
dopoulou, "Mycenaean Burial Customs in Minoan Culture," in Atti II" Congresso internazionale di micenologia (Rome, forth. coming); Papadopoulou, "The Tholos Tomb of the Late Minoan Cemetery at Armenoi of Rethymnon," 7th CretCong (forthcoming); M. Papathanassiou, M. Hoskin, and H. Papadopoulou, "Orientations of Tombs in the Late-Minoan Cemetery at Armenoi, Crete," Archaeoastronomy 17 (1992) 543-55; BCH 113 (1989) 692; BCH 118 (1994) 834; AR 36 (1990) 77. a Mycenaean practice. Other rich Final Palatial tombs have been excavated around Chania. ${ }^{430}$

In recent years, a number of large and important LM III tholos tombs have been excavated in western and eastern Crete. Three of these share the unusual feature of a rectangular chamber, two in the Chania area (Malame and Phylaki), ${ }^{431}$ and one south of Siteia at the edge of the settlement site at Achladia. Another architectural peculiarity further links the Malame and Phylaki tholoi: the lintel slab over the front facade, facing the dromos, is set vertically on end, to create a rectangular "plaque" over the doorway.

\section{Art}

Ceramics. LM II undecorated as well as decorated pottery has been recognized at an increasing number of sites. It used to be thought that the chronological phase LM II was virtually confined to Knossos, a situation we now know is not the case. ${ }^{432} \mathrm{LM}$ II pottery shows an increasing trend toward simplifying and fossilizing motifs, which some have attributed to increasing mainland influence, although the trend was already apparent in LM IB and need not reflect either mainland influence or conquest. These general trends continue into LM IIIA and B in a clear evolutionary development with few interruptions. ${ }^{433}$

Three shapes have been considered typical of LM II: flat alabastra, Ephyraean goblets, and Palace Style jars. The flat alabastron is a shape that occurred in LM IB and on the mainland but became popular on Crete in LM II, both in pottery and in stone, the latter examples probably produced only at Knossos. During LM II/LH IIB, another mainland shape, the Ephyraean goblet, is also produced on Crete and in nearly identical forms. ${ }^{434}$ Contrasting sharply with the earlier semiglobular cup and the Vapheio cup, the Cretan goblets tend to be decorated with a rel-

${ }^{430}$ B.P. Hallager and P. McGeorge, Late Minoan III Burials at Khania (SIMA 93, Göteborg 1992); Karantzali (supra n. 427); $A R 38$ (1992) 70; $A R 40$ (1994) 84; BCH 118 (1994) 835-36.

${ }^{431}$ Malame: Prakt 1966, 185-88; Ergon 1966, 144-47. Phy. laki: supra n. 427.

${ }^{432}$ Supra n. 408. S. Hiller, "Der SM II-Palaststil," in Po. liteia 561-73; M.R. Popham, "LM II Crete," AJA 79 (1975) 372-74; and Popham, "Cretan Sites Occupied between ca. 1450 and 1400 B.C.," BSA 75 (1980) 163-67; W.D. Niemeier, "Towards a New Definition of LM II," AJA 83 (1979) 212-14; L.V. Watrous, "The Relationship of Late Minoan II to Late Minoan III A:1," AJA 85 (1981) 75-77; B.P. Hallager, in 6th CretCong (supra n. 412); Hallager and Tzedakis 1984 (supra n. 50) 11-12.

${ }^{433}$ Popham (supra n. 189); M.R. Popham, "Late Minoan III B Pottery from Knossos," BSA 65 (1970) 195-202.

${ }^{434}$ P. Mountjoy, "The Ephyrean Goblet Revisited," BSA 78 (1983) 265-71. 
atively small number of motifs, usually the same on each side of the vessel: a stylized argonaut, a rosette, a lily, a palm tree, and a few other designs; a few examples are decorated in the Marine Style. The Palace Style jar is another characteristic LM II shape that descends from the large LM IB jar. These jars are imitated extensively on the mainland in LH IIA; in LM II Crete their decoration becomes increasingly schematic and simplified. ${ }^{435}$

Another important development in LM II is the increasing appearance of pictorial pottery on Crete, especially pieces depicting the human figure or birds. ${ }^{436}$ Two early examples come from the Unexplored Mansion, a jug depicting a hunter with a spear and a pyxis with birds; both scenes recur on larnakes.

The development of LM IIIA pottery closely follows that of Mycenaean IIIA. ${ }^{437}$ The decorations include animals, birds, and exotic plant life, as well as abstract patterns. All are rendered with confidence in an even style throughout the island that probably reflects close contacts. The cup with an everted or ledge-like rim appears first in IIIA1 and is paralleled by the kylix, a development of the Ephyraean goblet toward a shallower body and taller stem. Earlier shapes, like the krater and the stirrup jar, ${ }^{438}$ now become common, while the conical cup finally declines in popularity. At the beginning of LM IIIA2, the onehandled goblet or champagne cup with a low stem makes its appearance and these begin to replace the ledge-rimmed cup; in contrast, the kylix becomes

435 Marine Style: Popham et al. (supra n. 5) pl. 124b. Palace Style jar: W.D. Niemeier, Die Palaststilkeramik von Knossos: Stil, Chronologie und historischer Kontext (Berlin 1985).

${ }^{436}$ There is some pictorial pottery before the Cretan destructions: e.g., $B C H 107$ (1983) 830-31, fig. 155.J.H. Crouwel and C.E. Morris, BSA 90 (1995) 157-82; M.R. Popham, in Evely et al. (supra n. 1) 98-101; Popham et al. (supra n. 5) pls. 62a-b and 153.6-7, and 65b and 155.1.

437 Betancourt (supra n. 4) 163-72.

${ }^{438}$ H. Haskell, "From Palace to Town Administration," in Society 121-28; Haskell, The Coarse Ware Stirrup Jars of Crete and the Cyclades (Diss. Univ. of North Carolina 1981); A. Leonard et al., "The Making of Aegean Stirrup Jars," BSA 88 (1994) 105-23.

${ }^{439}$ Tzedakis (supra n. 410); Karantzali (supra n. 427); Kommos III, 152, 182.

${ }^{440}$ Begg 109-10 lists storage larnakes from Neopalatial Thera A2, Zakros Strong Building fallen from above and House A, Vathypetro from above room 4 and the southeast wing, and Phaistos; and from Final Palatial Gournia Ej.58 or 59, and Knossos Little Palace; the larnax in the South Entrance System of Knossos should also be a stor. age chest. General studies: B. Rutkowski, Larnaksy Egejskie (Warsaw 1966); Rutkowski, "The Origin of the Minoan Coffin," BSA 63 (1968) 219-27; Hägg and Sieurin (supra n. 259); and L.V. Watrous, "The Origin and Iconography less popular as its stem becomes even taller. What few naturalistic motifs remain are gradually replaced by more abstract patterns.

In LM IIIA a new workshop at Chania begins producing a distinctive pottery whose fabric is pale gray with a yellow or pale orange slip and whose biscuit turns sugary white when scratched. The workshop flourishes in LM IIIA2, dramatically so in LM IIIB, before tapering off in LM IIIC. ${ }^{439}$ Its pottery is exported not only throughout the island, but also to Cyprus, Sardinia, and the Greek mainland.

Larnakes. Clay larnakes, in use throughout the Proto- and Neopalatial periods as coffins, and occasionally as storage containers in the Neopalatial and Final Palatial periods, come in two shapes, the chest larnax and the tub larnax, both perhaps inspired by wooden prototypes. ${ }^{440}$ The gabled lids are separate, and usually fit tightly atop the clay chest. The box shape of the chest larnax created four rectangular side panels for painted decoration, six in the case of larnakes that have an extra set of legs in the middle of their long sides. These rectangular or square side panels are reminiscent of wall surfaces in buildings, and invited the type of decoration found in wall frescoes or in woven textiles.

As coffins they become popular in the Final Palatial period, and their decoration is often elaborate. They are thus an important source of information about Late Minoan iconography and beliefs. Run. ning spirals, circles, and wavy bands are common

of the Late Minoan Painted Larnax," Hesperia 60 (1991) 285-307. Regional studies: K. Mavriyannaki, Recherches sur les larnakes minoennes de la Crète occidentale (Rome 1972); Mav-

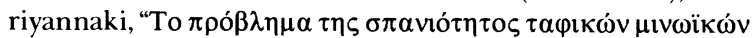

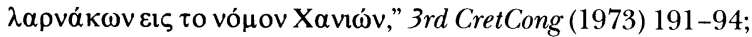

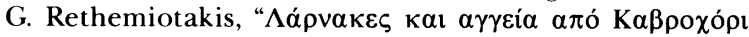

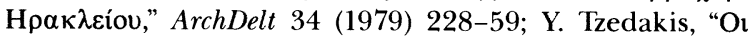

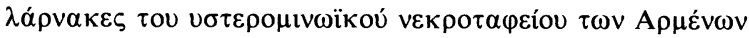

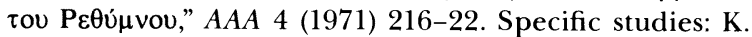

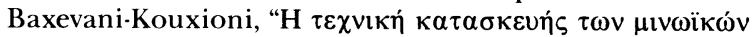
$\lambda \alpha \rho v \alpha \kappa \omega ́ v, " 8 t h$ CretCong (forthcoming); Mavriyannaki, "Une larnax inscrite provenant de Chouméri Mylopotamou," Kadmos 24 (1985) 13-22; L. Morgan, "A Minoan Larnax from Knossos," BSA 82 (1987) 171-200; M. Poloyioryi,

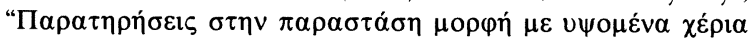

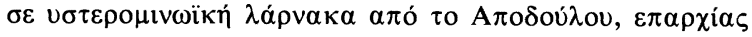

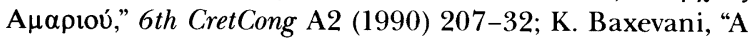
Minoan Larnax from Pigi Rethymnou," in C. Morris ed., Klados (London 1995) 15-33. Attribution studies: C. Morris, "Fishy Tales from Knossos," in Klados 185-93; and M. Tsipopoulou and L. Vagnetti, "Workshop Attributions for Some Late Minoan III East Cretan Larnakes," in Techne 473-79. Specific examples illustrated: Demakopoulou (supra n. 384) 76-77, no. 6; Godart and Tzedakis (supra n. 427) pls. CIX.1-2, CX.1, CXIV.3, CXIX.1-2, CXX-CXVI, CXXVII.1, CLVI; cf. I. Papapostolou, Prakt 1974, 247-56, pls. 185-91. 
decorations on the legs and horizontal raised bands at the top and bottom. The side panels often include argonauts and octopi, fish, plants, birds, and animals, of which bulls, deer, and agrimia are the most frequent. The landscapes that had ceased to appear in fresco at the end of the Neopalatial period now appear in abbreviated forms on larnakes, but fish and fowl are sometimes mingled. A cult symbol that appears frequently is the horns of consecration; one larnax in Rethymnon shows horns set atop an incurved base.

Human figures, mostly men, appear infrequently. One panel of a sarcophagus from Armenoi depicts a landscape with rockwork where a hunter armed with sword and spear lets fly at an outsized deer while he holds a dog on a tether in his free hand. On the end of the gabled lid of another larnax from Armenoi a mourning figure stands beside the deceased individual who is stretched out on a bier, perhaps a wooden one like those found in contemporary tombs. This may be our earliest prothesis scene, well known in Geometric art.

From a tomb northeast of the villa at Ayia Triada comes a unique, frescoed limestone sarcophagus. ${ }^{441}$ The legs of the Ayia Triada sarcophagus and the roughly contemporary larnax from Archanes Tholos A are painted similarly with vertical bands of running spirals. One long side of the sarcophagus shows the sacrifice of a bull and an offering at an altar in front of a small built shrine. All of the figures here are women, except for a male aulete. The other long side depicts the pouring of liquid offerings and a procession of three men holding small bulls (rhyta?) and a boat model moving toward an armless male figure standing before a building who may represent the deceased before his tomb. ${ }^{442}$ The end panels also show important scenes. One shows two women riding in a dual chariot drawn by agrimia altered from horses, the other a pair of women in a chariot drawn by griffins. Over the backs of the griffins ca-

${ }^{441}$ C. Long, The Ayia Triada Sarcophagus (SIMA 41, Göteborg 1974); Hood (supra n. 157) 70-71, figs. 53-54; CM pls. XXVII-XXX.

${ }^{442} \mathrm{Cf}$. the large $(45 \mathrm{~cm}$ long) terracotta boat model from a tomb on Cyprus: $A R 12$ (1966) 29-30, fig. 3a-b, and the Neopalatial alabaster boat found at Ayia Triada: Halbherr et al. (supra n. 31) 90 fig. 56. E. French suggests that the man might represent a large terracotta figurine: "Mycenaean Figures and Figurines," in Sanctuaries 174. For other interpretations, see, e.g., R. Laffineur, "À propos du sarcophage d'Aghia Triadha," Kernos 4 (1991) 277-85. The painted facade of the tomb recalls Mycenaean practices: K. Demakopoulou, "The Burial Ritual in the Tholos Tomb at Kokla, Argolis," in Hägg and Nordquist (supra n. 221) 113, 116 vorts a small, birdlike creature, probably a baby griffin since it shares the blue, white, and yellow colors of the adults.

Frescoes. Only two sites have produced significant evidence of fresco painting after LM IB: Knossos and Ayia Triada, though at the former some Neopalatial compositions remained on the walls. Almost no Cretan frescoes can be dated to LM IIIA2-B, with the possible exception of the frescoes in the Knossos throne room complex, the final architectural modification of which has been dated to LM IIIA2. On the walls flanking the stone throne are a pair of palm trees and recumbent antithetic wingless griffins (the papyrus blossoms included in Evans's reconstruction and often reproduced are a mistake). ${ }^{443}$ This scheme, like the throne, probably repeats a Neopalatial arrangement. In the east wing at Knossos, a fresco of dolphins has been attributed to a floor. ${ }^{444}$

The wall frescoes at Knossos assigned to the Final Palatial period on stylistic grounds show that some Minoan customs may have continued on Crete, particularly those connected with the high status of women and the social importance of ritual activity. These paintings include the Toreador Panels with female, as well as male, bull-leapers, and a possible administrator or ruler in a dual chariot who wears the diagonally banded robe of men on some Neopalatial sealstones, along with a sword baldric slung around his neck. ${ }^{445}$

Both sides of the west entrance corridor of the palace were lined with life-sized processional figures of at least two women and approximately 20 men, some carrying metal and stone vases. ${ }^{446}$ Both old and new elements can be seen. Although processions of men occurred on the Neopalatial Harvester Vase and in a fresco from Xeste 4 at Akrotiri, they now become standard in Mycenaean painting. Both women wear the Neopalatial Minoan robe and apron, garments now highly stylized, and perhaps worn only on special ritual occasions. The central figure in the

fig. 4; K. Müller, "Das Kuppelgrab von Tiryns," Tiryns VII (Mainz 1975) 2; O. Pelon, Tholoi, tumuli et cercles funéraires (Athens 1976) 181, 319; C. Blegen, Prosymna (Cambridge 1937) pl. 39.

${ }^{443}$ M. Shaw, "The Aegean Garden," AJA 97 (1993) 677, fig. 16 for a recent, correct restoration.

${ }^{444}$ R.B. Koehl, "A Marinescape Floor from the Palace at Knossos," AJA 90 (1986) 407-17.

${ }^{445}$ Fragments are divided between the Ashmolean Museum and the Herakleion Museum: Immerwahr 175-76 Kn nos. 23 and 25; S. Alexiou, "Neue Wagendarstellungen aus Kreta," $A A$ 1964, 785-804; cf. the similar composition on CMS I, no. 229.

${ }^{446} P M$ II.2, 679-85; Immerwahr 174-75 Kn no. 22. 
procession is a woman, separated in space from the files approaching from either side. She wears a dress patterned with beam ends and triglyph-half rosette designs, ${ }^{447}$ architectural elements that had been important in the iconography of the Neopalatial palaces and their peak sanctuaries. Several men wear costumes whose detailed patterns and surface treatments recall those in Neopalatial paintings, and at least two individuals wear the early hide skirts, but others in the procession wear a new garment, the long tunic, a "unisex" robe increasingly evident in Mycenaean representations. The breechcloth and codpiece, which had been so prominent in Neopalatial art, are apparently missing from the Procession Fresco and are now confined to scenes of bull-leaping, even on the mainland. ${ }^{448}$ Even the undulating, horizontal background bands, alternately red and white, recall similar backgrounds from the earlier House of the Frescoes, but here they are static and repetitious as in subsequent Mycenaean painting.

The multiple registers of the Campstool Fresco present intriguing problems of reconstruction and interpretation. Men sitting on campstools wear diagonally banded robes and toast each other with LM IIIA stemmed kylikes in the presence of at least two women. ${ }^{449}$ One of the women, facing left against a yellow background, is at the same small scale as the men. The other woman, facing right against a blue background, is larger. Dubbed "La Parisienne" by Evans, she is armless like the presumed deceased on the Ayia Triada sarcophagus and wears an unusual garment with a sacral knot attached to the collar at the back. As in the Procession Fresco, men are

${ }^{447}$ PM II.2, 719-36, Suppl. pl. XXV fig. 7; C. Boulotis, "Nochmals zum Prozessionsfresko von Knossos," in Palaces 145-55. Cf. the bodice of the Thera goddess from Xeste 3: Doumas pl. 125.

${ }^{448}$ The only possible processional figure wearing a breechcloth occurs on a fresco fragment (PM II.2, 751 fig. $485)$ that Evans found just south of the Procession Corridor. Cameron (supra n. 335) 587, pl. 4, dates it to Neopalatial and moves it to the east wing to accompany the Grand Staircase, though the relative difference in height of the figures cannot match the changes in height of the staircase's risers.

${ }^{449}$ PM IV.2, 379-90, pl. XXX B; Immerwahr 95, 176 Kn no. 26, pl. 44; M.A.S. Cameron, "An Addition to 'La Parisienne," CretChron 18 (1964) 38-53. Two fragments (PM IV, pl. XXXI A and G) present the kylix, one the bowl, the other the tall stem; if pottery, the kylix could be as late as LM IIIA2. J. Wright, "Empty Cups and Empty Jugs," in P.E. McGovern, S.J. Fleming, and S.H. Katz eds., The Origins and Ancient History of Wine (Philadelphia 1995) suggests there are two cups, a chalice for Minoans and a gob- more numerous than women, reversing the gender imbalance of Neopalatial art, and their red sword baldrics and campstools with distinctive red tassels may allude to their high status.

Sealstones. Knossian workshops were still producing seals in the Final Palatial period, but it now becomes difficult to distinguish between Cretan and mainland products, as if the gem engravers or even entire workshops were moving around and finding new homes. Sealstones whose animals have distinctively rendered "spectacle eyes" were produced at Knossos in IIIA1, but the location of the IIIA2-B early Island Sanctuaries workshop that made seals with smoothly modeled animals cannot be determined precisely. ${ }^{450}$ In the Postpalatial period, hard stone seals were no longer produced in the Aegean (see below), although heirloom seals continued in circulation and were used on the mainland for administrative purposes.

Some Neopalatial gold cult rings evidently survived to be buried in Final Palatial tombs; other cult rings are more vigorous in style and these could date later, to LM II-IIIA. Similarly late could be a few flimsy rings of thin gold plate over a flat bronze core. ${ }^{451}$

Burials with bronzes are sometimes accompanied by large lentoids of a dark, rich red-brown agate, carved with bulls in recumbent poses. ${ }^{452}$ If this motif is an insigne, it would be tempting to link it with a high official.

Stone vessels. Following the LM IB destructions, there is a noticeable decline in the quality, variety of shapes, and volume of production of stone vases. Knossos housed a couple of stone workshops in LM

let for Mycenaeans.

450) Most, but not all, of the latest impressions at Knossos were made by seals belonging to the Spectacle Eyes group (Younger 1986 [supra n. 106] 121-38). Island Sanctuaries workshop: J.G. Younger, "The Island Sanctuaries Group," CMS Beiheft 1 (Berlin 1981) 263-72; Younger 1987 (supra n. 106) 61-64; I. Pini, "Minoan Glyptic after the Assumed Fall of the Palace at Knossos," BICS 29 (1982) 132.

451 Grave goods: Younger 1983 (supra n. 106) 134-35; Sellopoulo tomb 4 ring: Popham and Catling (supra n. 236) no. J8. Archanes ring: Archanes 79 fig. 53. Cultic rings: CMS I, nos. 126-29. Younger 1984 (supra n. 106) attributes these rings to the Group of the Buxom Women, none of whose members comes from a dated context earlier than LH II. Bronze core rings: Younger (supra n. 242) 87: ring type VI. Archanes rings: Archanes 62 fig. 37 (the pair at upper left and one at lower right). Kalyvia tomb 9: CMS II.3, no. 39. Sellopoulo tomb 4: Popham and Catling (supra n. 236) no. J7.

452 Younger 1988 (supra n. 106) 79-80 lists 26 examples; add CMS I, Suppl. 1A, no. 69 from Koukaki. 
II-IIIA, from which unworked or unfinished pieces exist, including a stock of unworked lapis lacedaemonius and unfinished gypsum vase fragments identified among debris swept into the cists of west magazine $13 .{ }^{453}$ Finished products of this gypsum vase workshop were found in the palace at Knossos and a few other sites. These include approximately a dozen baggy gypsum alabastra from the throne room complex, some with lids and most with rim decoration of compass-drawn running spirals with dotted centers and handles shaped like figure-eight shields. ${ }^{454}$ While the alabastron resembles a Mycenaean pottery shape, the dotted spirals and figureeight shield handles are Minoan. These gypsum vases were apparently in use at the time the palace was destroyed, though their exact purpose is unclear. They are too heavy to have been moved easily, and their contents (scented oil?) must have been taken out by dipper, not poured.

Stone vessels, many of which were deposited in tombs, continued to be imported from Syria or Egypt. One important vase inscribed with the name of Tuthmosis III found at Katsamba probably dates to this period but may be a Syrian imitation of an Egyptian vase. The Royal Tomb at Isopata, in use in LM II, contained a large number of imported stone vessels, including a shallow footed bowl with carinated sides. Similar examples have been found in Cyprus, SyriaPalestine, and Egypt, indicating that Crete was still part of an international network of trade. ${ }^{455}$

Metalwork. During the Final Palatial period, Knossos was still a center for the production of bronze tools and weapons. Of particular importance is the

${ }^{453}$ P. Warren, "Two Palatial Stone Vases from Knossos," BSA 60 (1965) 154-55; Evely (supra n. 154); Begg 77, 204 ns. $650-51$.

454 PM IV.2, 937-39 fig. 910; H. von Arbin, "The Alabastron-Shaped Vases Found in the Throne Room at Knossos," OpAth 15 (1984) 7-11; P. Magrill, "A Minoan Alabastron in Dublin," BSA 82 (1987) 155-64; R. Hägg, "The Last Ceremony in the Throne Room at Knossos," OpAth 17 (1988) 99-106; H. Waterhouse, "The Flat Alabastron and the Last Ritual in the Knossos Throne Room," OJA 7 (1988) 361-67; H. Busing, "Zum Spiralschmuck der steineren Alabastra aus dem Thronsaal von Knossos," JRGZM 40 (1993) 317-31, pl. 32; Rehak (supra n. 385). For the decoration, cf. a probable MM III fresco from the east wing at Knossos (PM I, 371 fig. 269; III, 30-31, pl. XV; Immerwahr $178 \mathrm{Kn}$ no. 38) and a relief fresco from Zakros (Zakros 172-73; Immerwahr 184 Za no. 1).

${ }^{455}$ Katsamba tomb beta: Alexiou (supra n. 158) pl. 10; Cline 189 no. 491. Lilyquist (supra n. 128) now thinks that the vessel may not be Egyptian. The inscribed vase is one of two imported stone vessels from the tomb, the other being an Egyptian diorite bowl: Cline 190 no. 496. Stone bronze workshop at the Unexplored Mansion in LM II. Analysis of these bronzes and bronze scrap shows that they contain lead from Lavrion, as do late bronzes from Ayia Irini in Kea, although that does not necessarily indicate where their copper came from. The metal vessels found in Warrior Graves on both Crete and the mainland at this time are virtually certain to have been produced at Knossos. ${ }^{456}$

Three new sword forms belong to LM II-IIIA and are made only during this time: types $\mathrm{Ci}, \mathrm{Di}$, and $\mathrm{G}$, all of which are found in Warrior Graves on Crete and in the Argolid. ${ }^{457}$ Type $\mathrm{C}$ swords are characterized by "horned" hand-guards, type D by cross-shaped hand-guards. Type Gi swords represent a variant of type $\mathrm{C}$ swords and have a "dropped horn" hand-guard. Continuing the earlier tradition of decorated blades, though less elaborately, these three types of swords may have decorated hilts and a midrib with incised decoration, while some spear points are similarly decorated ${ }^{458}$ After LM/LH IIIA, however, decorated weapons are no longer manufactured in the Aegean.

An elaborate cruciform (Di) sword from the Chieftain Grave at Zapher Papoura has a midrib and tang engraved with spirals, a gold foil hilt, and an agate pommel. Incised on the gold hilt are an antithetic addorsed lion and an agrimi; the same animals ap. pear in a chase scene on the hand grip. The design is important because of its pictorial style, recalling Neopalatial frescoes and the landscapes with pendant rockwork, as on the gold Vapheio cups. On the sword hilt there is even an attempt to render foliage, a single crocus flower blooming among the rocks. Also manufactured about this time are a spearhead

vessels from the Royal Tomb include two alabaster bowls, a diorite bowl, a porphyrite bowl, and an alabaster jug (Cline 189 nos. 489-90, 495, 504, 629, respectively). For an example of a footed bowl in Cyprus, see I. Todd et al., "Kalavasos. Mangia," RDAC 1988, 218.

${ }^{456} \mathrm{C}$. Macdonald, "A Knossian Weapon Workshop in Late Minoan II and III A," in Palaces 293-95. Unexplored Mansion: H.W. Catling and E.W. Catling, "The Bronzes and Metalworking Equipment," in Popham et al. (supra n. 5) 203-22. Knapp et al. (supra n. 210) 57-58, 258: the metallurgical evidence in the Minoan Unexplored Mansion is for vessel production, not smelting. Warrior Graves: Popham and Catling (supra n. 236) 203-22; H. Matthäus, "Representations of Keftiu in Egyptian Tombs," BICS 40 (1995) 177-94.

${ }^{457} \mathrm{~J}$. Driessen and C. Macdonald, "Some Military As. pects of the Aegean in the Late Fifteenth and Early Four. teenth Centuries B.C., Part II: Aegean Swords and Warrior Graves," BSA 79 (1984) 72-74 (catalogue); Macdonald (supra n. 456).

${ }^{458}$ Höckmann (supra n. 216); for an example decorated with spirals from Archanes, see Archanes 110. 
from a tomb at Archanes, decorated with running spirals, and the Lasithi dagger with incised decoration showing a man hunting a boar on one side and two bulls fighting on the other, a lineal descendant of the much more elaborately rendered scenes on the Neopalatial niello daggers. ${ }^{459}$

Precious metals continue to be used for jewelry and other ornaments, but many of these are of thin foil, often mass-produced in molds. At Archanes Phourni, funerary building 3 contained a large goldfoil cutout of a figure-eight shield that may have decorated a wooden box or piece of furniture, and the LM IIIA burials in Tholoi A and D included gold rosette necklaces or dress beads and a series of double argonaut beads that were evidently worn around the head as a diadem. ${ }^{460}$

With the LM IIIA1-2 disruption at Knossos, the relative homogeneity of Aegean metalwork breaks down, suggesting that there was no longer a single major palatial workshop on Crete. There is less evidence for the manufacture of large bronze vessels, decorated swords virtually disappear, and precious metal jewelry becomes increasingly scarce in habitation and funerary contexts.

Important recent evidence for bronzeworking in the first half of LM IIIB comes from Palaikastro, where a pit was found in 1991 containing metal debris, tuyères, crucibles, and molds for a double ax and a tripod stand of the type more familiar from Late Cypriot IIIA contexts in Cyprus. The Cretan example is important because it predates the earliest Late Cypriot IIC example found at Kaloriziki tomb 40 and is larger than the ones often used in tombs. ${ }^{461}$

Ivories. Despite the fact that three-dimensional ivory figurines were no longer carved by the end of LM IB, a group of surviving Neopalatial ivories, prob-

${ }^{459}$ Zapher Papoura: Evans (supra n. 148) 55-58. A lapis lacedaemonius pommel with a gold foil ferrule found at Nichoria on the mainland probably came from a Knossos workshop as well (McDonald and Wilkie [supra n. 354] 262 no. 1008, 325 fig. 5-27, 845 pl. 5-52). Cf. the Zapher Papoura hilt foliage with the single clump of blooming crocus on the Zakros Sanctuary Rhyton (Shaw [supra n. 134] 434 figs. 7-8). Archanes spearhead: $B C H 91$ (1967) 792 fig. 19. See also C. Long, "The Lasithi Dagger," AJA 82 (1978) 35-46. ${ }^{460}$ Archanes 110, 130 fig. 108, 132 fig. 110.

${ }^{461}$ S.A. Hemingway, "Minoan Metalworking in the Postpalatial Period," BSA 91 (1996) 213-52. PGC no. 1687. Cf. T.M. Cross, Bronze Tripods and Related Stands in the Eastern Mediterranean from the 12th through the 7th Centuries B.C. (Diss. Univ. of North Carolina 1974).

${ }^{462} A R 4$ (1958) 22, pl. 2a; and $A R 5$ (1959) 20 and fig. 33: ivory foot.

${ }^{463}$ Archanes 71 col. fig. 45, 108 fig. 83, 109 fig. 84; Pour- ably heirlooms, was found along the Royal Road in a LM IIIA context. ${ }^{462}$ Other ivory products, stylistically datable slightly before or after the Cretan destructions, may also have been produced at Knossos. Among these is an ivory comb from the Mycenaean grave enclosure at Archanes Phourni and, from funerary building 3 there, several plaques that probably decorated a wooden box or piece of furniture. Four horizontal plaques, carved with almost identical lions in a flying gallop, recall the gilded hexagonal wooden box from Circle A at Mycenae; both these lions and the agrimi on the large plaque have almond-shaped eyes, a shape that is popular on sealstones in LM IB-II. ${ }^{463}$ A Knossian workshop may also have been responsible for producing what is apparently a new type of status symbol: a footstool inlaid with ivory figure-eight shields and warrior's heads. These have been found in tholos tombs at Archanes and at Phylaki Apokoronou, as well as on the mainland. ${ }^{464}$

The ivories from the tholos at Phylaki are important because they expand the Cretan artistic repertory in this medium. One plaque, carved front and back, has a tenon at the bottom, perhaps for insertion into a piece of furniture or a scepter. Two antithetic kneeling male figures are shown embracing, in a pose somewhat reminiscent of the women on the Mycenae ivory triad. Parts of three more male figures, carved in the round, were also found, along with crudely carved ivory plaques with standing sphinxes. A trait shared by all the faces of the Phylaki ivories, including the warriors' heads on the footstool, is the carving of the eye in relief as an almond shape, with no indication of a pupil; compare the similar eye of a sphinx on an ivory pyxis from a chamber tomb at Thebes. ${ }^{465}$

Faience. Cretan faience manufacture lingered into

sat, Les ivoires (supra n. 153) pls. VI.1-2, VII.1-2. Cf. the comb from Katsamba tomb eta: Alexiou (supra n. 158) pls. 34-35. Almond-eyes on sealstones: J.G. Younger, "A Large Stylistic Group of the Late XVth Century," CMS Beiheft 3 (Berlin 1989) 339-53; Younger 1985 (supra n. 106) 53-62.

${ }^{464}$ I.A. Sakellarakis, "Mycenaean Footstools," in Herr. mann (supra n. 155) 105-10. Illustrations of examples include Archanes 82 fig. 59, 83 fig. 60 from Archanes; Poursat, Les ivoires (supra n. 153) pls. IV.1 (Mycenae), IV.3 (Thebes), VII.3 (Archanes), XIV.4 (Delos); and, from Phylaki, $B C H$ 106 (1982) 630 fig. 182 (head only); Godart and Tzedakis (supra n. 427) pls. LVII.1-2 (heads), and LV.1-2 and LVII.3 (shields).

465 Phylaki: Godart and Tzedakis (supra n. 427) pls. LVI.3-4, LXV.1-2. Cf. the ivory pyxis from Thebes: Poursat, Les ivoires (supra n. 153) pl. V.6. For color illustrations: Poursat 1994 (supra n. 158) 88 col. fig.; and Demakopoulou (supra n. 384) 72, no. 3. 
LM II-IIIA; for instance, Mycenae chamber tomb 102 produced a faience hilt for a Knossian type D sword, clearly a prestige item, and from Tholos D at Archanes Phourni (LM IIIA2 context) come a variety of simple faience beads. ${ }^{466}$ There is no good evidence for faience manufacture on Crete after the beginning of IIIB.

\section{Writing and Administration}

The relationship of Linear B to Linear A has been analyzed extensively. It is often and wrongly assumed that Linear A developed into Linear B, that the two scripts are mutually exclusive, and that, since Linear B was used to write Greek, Linear A reflects a nonGreek language. While Linear B inherited numerous features from Linear A, including most of its syllabary, some interesting changes also occur. Linear B's writing style is more cursive, perhaps revealing a candid response to the papyrus and leather texts that the Neopalatial one-hole hanging nodules imply. Furthermore, Linear B often uses a format that strives for redundant clarity in its statements. ${ }^{467}$

From Knossos come over 3,000 inscribed Linear B tablets (fewer than 2,400 with provenience known) and 69 inscribed (19 with provenience known) and approximately 400 impressed nodules whose LM III

466 Mycenae: Wace (supra n. 354) 281 no. 4910, pl. 137. Archanes: Archanes 131 fig. 109.

${ }^{467}$ Linear B uses far fewer ligatures than Linear A. Whereas Linear A either uses the word or the ideogram for a commodity, rarely both (HT 88.2: FICus KI-KI-NA 7), Linear B usually uses both.

468 Knossos: Palaima (supra n. 279) 504 gives the numbers of documents; J.P. Olivier, Les scribes de Cnossos (Rome 1967) gives the findspots at Knossos where known, although J.T. Killen and J.P. Olivier, The Knossos Tablets ${ }^{5}$ (Salamanca 1989) $\left[K T^{5}\right]$ xiv, emphasize caution. LM III date: Popham and Gill (supra n. 391) 56. Chania: L. Godart and Y. Tzedakis, "La storia della Lineare B e le scoperte di Armenoi e la Canea," RivFil 117 (1989) 385-409; Godart and Tzedakis, "Les nouveaux textes en Linéaire B de la Canée," RivFil 119 (1991) 129-45; E. Hallager, M. Vlasakis, and B.P. Hallager, "The First Linear B Tablet(s) from Khania," Kad. mos 29 (1990) 24-34; Hallager et al. (supra n. 273).

ISJs: Jones 477-94 gives a summary and basic bibliog. raphy; add Shelmerdine (supra n. 16) 556 and 565. ISJ Cretan proveniences: singletons from a provenience unknown, the Mamelouka Cave near Chania, Armenoi, and Knossos; 3 from Mallia; and 23 from Chania. Minoan context dates range from LM IIIA2 (Chania $\mathrm{Z27}$ ) to LM IIIB2 (Mallia: J.M. Driessen and A. Farnoux, "Mycenaeans at Malia?" Ae. gean Archaeology 1 [1994] 54-64; cf. AR 38 [1993] 65-66, fig. 56). While most Minoan ISJs were made from West Cretan clays (e.g., Chania Z27), two from Crete were made from Mid-Central Cretan clay (Armenoi and Knossos Z1716). From Knossos tablet K778, we know the Mycenaean name and ideogram for stirrup jars: ka-ra-re-u and $* 210^{\text {vas }}$. date is presumed. From Chania come three or possibly five tablets but no inscribed nodules; and from various places in Crete come 29 inscribed stirrup jars or their fragments. ${ }^{468}$ While the amount of administrative material from Knossos is thus large, its incomplete publication makes working with the material difficult. ${ }^{49}$ Chania provides the only ceramically dated contexts for Linear B documents. Three Linear B tablets were found on the floor of House I, room E, destroyed by fire early in LM IIIB, while another comes from pit $\mathrm{H}$ (primarily LM IIIA2 and B early pottery). 470

No central or "final" archives deposit has been securely identified at Knossos. Instead, throughout the palace there are concentrations of tablets whose specific subjects suggest scattered bureaus, stores, or workshops. ${ }^{471}$ The few inscribed and impressed nodules with known findspots also support the identification of "living" and "temporary" archives in stor. age and work areas rather than a "final" archives. Until relatively recently, it had been presumed that all the clay Linear B texts at Knossos belonged to a single administrative period, and had been fired hard in a single and final conflagration that also destroyed the palace. There are indications, however, that this "unity of the archives" ${ }^{\text {"772 }}$ did not exist.

\footnotetext{
${ }^{469}$ Evans's notebooks and Mackenzie's daybooks, the diaries of the excavations, have not yet been fully published; for some citations: L.R. Palmer and J. Boardman, On the Knossos Tablets (Oxford 1963). For the two latest corpora of tablets, see $K T^{5}$ (supra n. 468); and J. Chadwick et al., Corpus of Mycenaean Inscriptions from Knossos I (1-1063) (Cambridge 1986), and II (1064-4495) (Cambridge 1990). The impressed nodules will soon be published in $C M S$; also see M.A.V. Gill, “The Knossos Sealings," BSA 60 (1965) 58-98, updated by Popham and Gill (supra n. 391); for stylistic dates of the seals that impressed the nodules, see Younger, the Kadmos series (supra n. 106); for some of the classes, shapes, and types of nodules, see Hallager, and Weingarten 1988 (supra n. 269).

${ }^{470}$ We are grateful to E. Hallager and B.P. Hallager for showing us the inscribed material. For practical reasons, that portion of the floor on which tablets $\mathrm{KH} \mathrm{Ar} \mathrm{4,} \mathrm{Gq}$ 5 , and X 6 lay was excised for removal to the Chania Museum, where it is still stored and where we saw it: the floor is neatly strewn with pebbles and we could easily see where the tablets had lain since they had slightly depressed the pebbles. Hallager et al. (supra n. 468).

${ }^{471}$ The D series concerning sheep comes from the east-west corridor in the east wing; the As/Ak and $\mathrm{L}$ series concerning personnel and cloth come from magazine $\mathrm{XV}$; and the $S$ series concerning arms and armor comes from both the Corridor of the Sword Tablets and the Arsenal: S. Hiller, "The 'Corridor of the Sword Tablets' and the 'Arsenal," in Olivier ed. (supra n. 414) 303-14.

${ }^{472}$ L.R. Palmer, "The Find-Places of the Knossos Tablets," in Palmer and Boardman (supra n. 469) 170-72.
} 
Evans himself had selected the so-called Hieroglyphic Deposit from among scattered Linear B tablets and late impressed nodules. ${ }^{473}$ Driessen has established that the tablets from the Room of the Chariot Tablets were fired probably in LM II or early IIIA. ${ }^{474}$

The mix of Hieroglyphic and Linear B material in the west wing suggests the presence of "discard" archives. In fact, the lack of an identifiable main archive at Knossos may imply at least that other deposits of documents belong to "discard" archives. ${ }^{475}$ If so, their firing, whether by one burning or several (e.g., by fires in LM IIIA2 early as well as in IIIB early), could have occurred long after the documents were inscribed and the nodules impressed. This more haphazard survival of the documents may account for the often noted incompleteness of several series. ${ }^{476}$

The controversy over the "final destruction" at Knossos has spanned four decades. ${ }^{477}$ In 1958 Blegen noted that Linear B at Pylos (dated LH IIIB2-C1) was too much like Linear B at Knossos to warrant a long chronological gap between them. Four years later, Palmer and Boardman published their debate over the stratigraphy at Knossos, with the eventual result that Evans's LM II date for the "final destruction" of the palace was revised downward at least to LM IIIA early. Palmer later adduced strong reasons for proposing a LM IIIB date. Popham conducted two thorough reexaminations of the pottery and came to the conclusion that, though there was a destruction by fire at Knossos in IIIB early, the major destruction responsible for burning the Linear B tablets occurred in IIIA late, which he eventually refined

\footnotetext{
${ }^{473}$ Hieroglyphic tablets and labels were found in the Area of the Pictographic Tablets (the sottoscala at the north end of the west wing's north-south corridor), in magazines $4,5,6,12$, and 13, in the Room of the Lady's Seat, and in the Room West of the Stone Drum; they were found with Linear B tablets in magazines 4, 12, and 13. Begg 190-91: "The conclusion is inescapable that the scattering of the Hieroglyphic tablets in the West Wing at Knossos was contemporary with the scattering of the Linear B tablets."

${ }^{474}$ J.M. Driessen, An Early Destruction in the Mycenaean Palace at Knossos (Louvain 1990). For reviews, see J. Bennet, AJA 97 (1993) 172-74, and M.R. Popham, JHS 113 (1993) 174-78. Cf. Driessen, "The Scribes of the 'Room of the Chariot Tablets," Minos Suppl. 10 (Salamanca 1988) 123-65; Driessen, The Room of the Chariot Tablets at Knossos (Diss. Katholieke Universiteit Leuven 1989); Driessen, "The Room of the Chariot Tablets Reconsidered," 6th CretCong A2 (1990) 267-75; G. Owens, "The Date of the Linear B Archive from the 'Room of the Chariot Tablets' at Knossos," Talanta 26-27 (1995) 29-48; C.W. Shelmerdine, "Historical and Economic Considerations in Interpreting Mycenaean Texts," in Olivier (supra n. 414) 569-90, esp. 571 and 585.

475 Tablets and impressed nodules were found under a blocked doorway in the east wing: J.T. Hooker, "The "Unity of the Archives' at Knossos," Kadmos 4 (1965) 114-21.

476 The Da-Dg series, for instance, records only partly
}

to IIIA2 early. In the late 1970s Hallager came forward as one of the first to support Palmer's case for the IIIB destruction, and Niemeier soon added more arguments. In order to resolve Blegen's problem, Popham has recently suggested raising Pylos's destruction to very early LH IIIB. As noted in our introduction, we favor the early LM IIIB date for the end of palatial administration at Knossos.

In addition to the difficult problems in reconstructing the original stratigraphy and refining Minoan ceramic phases, the phrase "final destruction" implies assumptions concerning the importance of the palace as capital of the island or simply as regional center, the finality of its destruction (obliteration or one of a series of setbacks?), and, most important, its "Minoan" or "Mycenaean" cultural and ethnic character. The difference between a "final" destruction in LM IIIA2 early and IIIB early is not great in terms of years, perhaps two generations, but the conventional cultural characterizations of these two periods are important: was a Minoan Knossos eradicated in IIIA to facilitate the growth of a Mycenaean empire that reached its zenith in IIIB, or was its destruction one of the earliest symptoms of the destabilization of that empire? The bias against locating Minoan culture beyond the boundaries of the Neopalatial period has produced severe dissonance in discussions of the island's later periods, especially LM IIIB-C, the period that has been, from the earliest scholarship, often characterized pejoratively ("squatters," "backwater"), whereas, as far as we can see, the Final Palatial period is just as distinctive as the Neopala.

the maintenance of flocks of sheep: P. Halstead, "Lost Sheep? On the Linear B Evidence for Breeding Flocks at Knossos and Pylos," Minos 25-26 (1990-1991) 343-65.

${ }^{477}$ C.W. Blegen, "A Chronological Problem," in E. Grumach ed., Minoica (Berlin 1958) 61-66; Palmer and Boardman (supra n. 469); L.R. Palmer, The Penultimate Palace of Knossos (Rome 1969); Popham (supra n. 93); M.R. Popham, The Last Days of the Palace at Knossos. Complete Vases of the Late Minoan III B Period (SIMA 5, Göteborg 1964); Popham, "Connections between Crete and Cyprus 1300-1100 B.C.," in Karageorghis (supra n. 206) 178-91; E. Hallager, The Mycenaean Palace at Knossos (Stockholm 1977); Hallager, "The History of the Palace at Knossos in the Late Minoan Period," SMEA 19 (1978) 17-33; Niemeier (supra n. 5); Popham, "The Historical Implication of the Linear B Archive at Knossos Dating Either c. 1400 or 1200 B.C.," Cretan Studies 1 (1988) 217-27; Popham, "Pylos: Reflections on the Date of Its Destruction and Its Iron Age Reoccupation," OJA 10 (1991) $315-24$. In this controversy it is usually assumed that the "final destruction" is of the main palace; the Little Palace and Arsenal were also destroyed by fire but the Arsenal's destruction may have been earlier while the Little Palace's may have been later (J. Boardman, "The Date of the Knossos Tablets," in Palmer and Boardman [supra n. 469] 66 and 69). 
tial. The Postpalatial period was probably one of Crete's most prosperous and peaceful until recent modernity.

In addition to stratigraphic and ceramic studies, there has been a major focus on the character and history of administration. Bennet and Shelmerdine have studied the political nature of Crete as a whole, and several scholars have concentrated on the clay nodules and their impressions. ${ }^{478}$ It seems logical that, when taking over the administration at Knossos, the Mycenaeans would have adapted the administrative procedures already in place and dating back, relatively unchanged, to the Neopalatial period. ${ }^{479}$ On the mainland, where one can analyze Mycenaean sealing practices more or less clearly, there are no leather document sealings characteristic of the Neopalatial period. Instead, the Mycenaeans seem to have resuscitated the use of jar-stoppers and to have used two-hole hanging nodules exclusively as the nodule adjunct to their written documents (fig. 5). ${ }^{480} \mathrm{Knos}$ sos, according to the nodules from the presumably pure Mycenaean deposits in the east wing, followed

478 See J. Bennet, "Knossos in Context," AJA 94 (1990) 193-211; Shelmerdine (supra n. 474); P. Warren, "The Destruction of the Palace of Knossos," in V. Karageorghis ed., The Civilizations of the Aegean and Their Diffusion in Cyprus and the Eastern Mediterranean, 2000-600 B.C. (Nicosia 1991) 32-37; Warren, "The Palace at Knossos and Its Administration during LM II-III A,” BICS 40 (1995) 244-46. See Popham and Gill (supra n. 391) for a photographic dossier of the latest nodules; Weingarten 1988 (supra n. 269) for the identification of Mycenaean class XIIB "molar." For LM IIIA2-B early seals that impressed nodules, see Younger 1987 (supra n. 106) 61-64, especially the nodule HMs 259, for which also see I. Pini, "Ein Siegelabdruck im Archäologischen Museum Iraklion," 3rd CretCong (1973) 221-30; and Pini, "Nochmals zu einem tönernen Siegelabdruck des Museums Iraklion," $\Phi_{i}^{\prime} \lambda_{l} \alpha \dot{\varepsilon} \pi \eta$ (supra n. 151) 300-303.

${ }^{479} \mathrm{~J}$. Bennet, Aspects of the Administrative Organisation of LM II-III B Crete (Diss. Cambridge Univ. 1986); Bennet (supra n. 292); articles in Olivier (supra n. 414). Mycenaeans may have exerted a more rigid control over administrative concerns and a greater reliance on writing to express them. We also see a slightly different filing system: many Linear A tablets record several commodities each and specify them by ideogram, but most Linear B tablets concern just one kind of commodity each. This procedure may reflect differences in the physical layout of some of the mainland palaces. Pylos had one storage area for oil and another for wine; the Knossos magazines, whose pithoi were of various shapes and sizes, may have been filled with an assortment of commodities. The items recorded on the tablets that fell into the magazines from rooms above may have had no connection with the objects stored in the magazines ( pace Begg 55-56, and Popham, in Popham and Gill [supra n. 391] 57).

${ }^{480}$ Weingarten 1988 (supra n. 269) 13: "All Pylian sealings are hanging nodules (most akin to Knossos Class VI/A)"; cf. Demakopoulou (supra n. 384) 210, no. 189. these Mycenaean practices, with the addition that the two-hole hanging nodules were also pressed against containers. Contemporary nodules at Mallia and Chania are similar. ${ }^{481}$

At Knossos few seals were used to impress more than one nodule, reflecting a SSS system with a lowintensive, nonelite pattern of seal use. It would therefore seem that nonresident seal owners were contributing commodities to the palace and sending them, perhaps as taxes, along with an impressed nodule. ${ }^{482}$ Evidence for the internal administration of the palace is slight.

There has been much speculation concerning the role of Knossos within the island in LM III. The arrangement of toponyms in the tablets clearly reveals that the palace recognized at least four separate geographical areas. A fifth grouping links a-mi-ni-so (Amnisos), ko-no-so (Knossos), and se-to-i-ja (Archanes/ Juktas?), perhaps because they were the main sanctuary sites. There must have been written communication not only from Knossos to these sites but also from these areas to Knossos. ${ }^{483}$

${ }^{481}$ Mallia (Driessen and Farnoux [supra n. 468] 61-62): two stirrup jar stoppers from Quartier Epsilon (LM IIIA; HMs 1049, O. Pelon, Malia. Maisons III [Paris 1970] 130-35, no. 265, pl. XXVI.4-6) and Quartier Nu (HMs 1042, $B C H$ 81 [1957] 693; $B C H 102$ [1978] 831-36), and a class XIIA nodule from Quartier Nu room X7 (Driessen and Farnoux [supra n. 468] 62, pl. IV.3). Chania (Hallager et al. [supra n. 273] 70-72): KH 1558 (LM IIIA1), a class XII nodule (Weingarten 1988 [supra n. 269] 7 n. 5); and the direct-object sealing KH 1568 (early LM IIIB).

482 Weingarten 1988 (supra n. 269) 14.

${ }^{483}$ Halstead (supra n. 476); Shelmerdine (supra n. 474) 573 and 578. Few of the 100 or so secure place-names can be equated with known sites (Bennet [supra n. 292] 236-38): ko-no-so "Knossos," a-mi-ni-so "Amnisos," tu-ri-so "Tylissos," pai-to "Phaistos," ku-do-ni-ja "Kydonia" or "Chania," a-pa-ta-wa "Aptera" from the archaic form Aptarwa. E. Scafa, "SU.

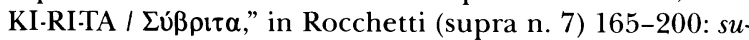
ki-ri-ta "Sybrita." A.L. Wilson, "The Place-Names in the Linear B Tablets from Knossos," Minos 16 (1977) 67-125 presents the geographical groups: group I, from Rethymnon/ Stavromenos (ku-ta-to?) down through the Amari valley to Phaistos (pa-i-to): da-wo, da-*22-to, e-ko-so, e-ra, pa-i-to (Phaistos), $k u$-ta-to; group II, the area east of the Pediada, perhaps even mentioning the Lasithi plain (ra-su-to): pu-na-so, ra-ja, ra-suto, ra-to, ri-jo-no, tu-ni-ja, do-ti-ja; group III, the north central plain itself containing Tylissos (tu-ri-so): a-ka, pu-so, qa-mo, qa-ra, ru-ki-to, su-ri-mo, ti-ri-to, tu-ri-so (Tylissos), u-ta-no; and group IV, a far west group mentions wa-to (Lato): o-du-ru-wo, *56-ko-we, si-ra-ro, wa-to (Lato). Add the ethnics pu-na-si-jo and wa-ti-jo on KH Ar4: Hallager et al. (supra n. 468). For se-to-i-ja, Bennet (supra n. 292) 241, 243 suggests either Mallia or, less likely, Archanes; Owens 1994 (supra n. 282) prefers Archanes. Bennet (supra n. 292) 231 n. 4: "ko-no-so-de," "to Knossos" appears on KN C5753, which may have been written at a western site and brought to Knossos for tally. ing since its scribe, 107 , deals only with western matters. 
Since Knossos was interested in separate districts from the far west to perhaps the western borders of Lasithi, ${ }^{484}$ it seems logical to assume that Knossos had some kind of centralizing control over the island, especially since some places mentioned in the tablets (e.g., Phaistos) do not appear archaeologically to have been able to function administratively on their own. On the other hand, the Neopalatial distribution of palaces and villas suggests at least a partial decentralization, which may have continued in the form of secondary regional centers surrounded by small settlements.

The Knossos tablets mention most of the conventional officials known in somewhat more detail on the mainland. The surprisingly small number of references, however, may reflect the tablets' focus on external administration. ${ }^{485}$ Much discussion has centered around the identity of those whose name in the genitive heads lists of workers; scholars refer to them as "collectors" or "supervisors." 486 One oddity is that the names of several collectors recur at various places in the Mycenaean world.

The interest of Knossos in the outlying areas centers mainly around the textile industry and the manufacture of four kinds of wool cloth, ${ }^{487}$ ranked according to thickness. Linen cloth is not fully recorded at Knossos, but may appear on one tablet as the material for the special garment $* 146$ (a tunic?). Borders $(o-n u-k e)$, fringes, and tassels (ko-ro-t $\left.a_{2}\right)$ are listed separately. Some male workers are recorded in the textile industry as fullers (ka-na-pe-we), who may also be finishers and decorators, and as weavers. Women, however, outnumber men 2 or 3 to 1, and these, along with their children and TA and DA supervisors, received allocations of raw material from the central authorities from which to make cloth. Tablets record

\footnotetext{
${ }^{484}$ Ra-su-to in group II may be "Lasithi," although that name cannot be traced earlier than the Byzantine period:

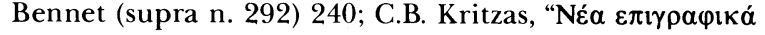

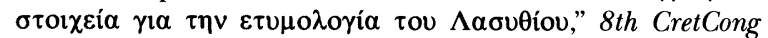
(forthcoming).

485 The wanax is associated with spice, and his bureaus are concerned with cloth and perhaps with purple dying (T.G. Palaima, "Maritime Matters in the Linear B Tablets," Aegaeum 7 [1991] 273-310); the bureau of the ra-wa-ke-ta is responsible for grain; Anutos, the qa-si-re-u at Knossos, and Sukereos, the qa-si-re-u at Setoija, are responsible for men; some te-re-ta hold plots of land in the central region, and a te-re-ta of Aptera is responsible for 45 men; the e-qe-ta Pisawatas is at Knossos, and an e-qe-si-ja bureau is responsible for fine cloth borders; a mayor (ko-re-te) in the west supplies an ox; and there is a vice-mayor (po-ro-ko-re-te) at $Q a-r a$, and an unknown functionary, the a-ke-re-mo-no.

${ }^{486}$ In Olivier (supra n. 414), see the following: J. Bennet, “'Collectors' or 'Owners'?” 65-101; J. Driessen, “'Collectors' Items', 197-214; L. Godart, "Les collecteurs dans le
}

production targets and the receipt of the final products in the palace. Female decorators (a-zelke-ti-ri-ja) are specialists, stationed outside Knossos, where special cloth is produced from which they make fancy borders. Other female cloth workers include weavers and spinners, women who make special kinds of cloth (ne-ki-ri-de workers, ko-u-ra cloth), "old women" (ka-ra-we, $\gamma \rho \alpha \hat{\varepsilon} \varepsilon \varsigma)$, and possibly "apprentices" (di[-da-ka-re $]$ ).

Related to the textiles is the interest in maintaining large flocks of sheep, especially wethers (castrated adult males) that produce the better wool. ${ }^{488}$ The flocks in areas far away were apparently administered by the collectors, while the flocks in nearer areas are grouped according to assembly places ( $a$-ko-ra-ja, related to áyopá?). Since the nearer sheep number twice as many as the farther sheep, and since the approximately 100,000 sheep listed in the Knossos tablets needed well over 100,000 ha of grazing land, it is likely that the main area of concern was Central Crete. $^{489}$

Another region that figures prominently is $D a-w o$, a place closely linked to Phaistos. Knossos tablet F(2) 852 records $10,000+$ units of grain there, or approximately $960,0001{ }^{490} \mathrm{Da}$-wo must be somewhere in the Mesara, which makes it certain that that plain functioned as a "breadbasket" as much in the Final Palatial period as it did in the Neopalatial.

\section{Trade and Interconnections}

It is difficult to assess Crete's contacts with the eastern Mediterranean in the Final Palatial period. LM pottery continues to be exported to Cyprus. On the basis of early LM IIIA2 pottery from the cemetery at Kition and because of the presence of horns of consecration at Kition, Myrtou-Pigadakia, and Pa-

monde égéen," 257-83. See also J.T. Killen, "The Knossos Ld(1) Tablets," in E. Risch and H. Mühlestein eds., Collo. quium Mycenaeum (Geneva 1979) 152-81, esp. 176-77.

${ }^{487}$ Killen (supra n. 486); J.T. Killen, "The Textile Industries at Pylos and Knossos," in C.W. Shelmerdine and T.G. Palaima eds., Pylos Comes Alive (New York 1984) 49-63: the thin pa-we-a ko-u-ra (1 unit wool: 1.7 units cloth), tu-na-no (3:1), TELA + TE (7:1), and the thick pe-ko-to (10:1).

${ }^{488} \mathrm{P}$. Halstead, "Counting Sheep in Neolithic and Bronze Age Greece," in I. Hodder, G. Isaac, and N. Hammond eds., Patterns in the Past (Cambridge 1981) 307-39.

489 The modern nome of Herakleion occupies approx. imately $2,800 \mathrm{~km}^{2}$ or 280,000 ha.

${ }^{490} \mathrm{M}$. Ventris and J. Chadwick, Documents in Mycenaean Greek (Cambridge 1959) 157-58, 170, 412 calculate this amount of GRA into rations (one unit equals $10 \mathrm{~T}$, and $2 \mathrm{~T}$ equals a monthly ration for a woman worker), approx. imately a month's ration for 50,000 women workers or a year's ration for 4,166 women workers. See L. Foxhall and

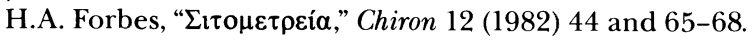


phos, Karageorghis identifies possible Minoan settlements and sanctuaries in the area of Kokkinokremos. Popham, however, postulates a suspension of trade between the two islands. ${ }^{491}$ The bulk of Aegean pottery found in Cyprus and the Near East is said to be Mycenaean, although this has not been scientifically tested. ${ }^{492}$ Minoan pottery, however, is found in the Near East and surprising amounts of Canaanite pottery come from Kommos, along with Egyptian pottery and Canaanite anchor stones. ${ }^{493}$

In the Final Palatial period, pottery workshops at Chania were producing wares that were exported elsewhere in Crete, to the Greek mainland and the Cyclades, east to Cyprus, and west to Italy and Sardinia. ${ }^{494}$ Chania was also producing stirrup jars for trade, some with painted inscriptions that were being exported to the mainland.

There are signs of growing contact with the west. ${ }^{495}$ Handmade burnished ware in typical subApennine shapes has been found at Kommos in IIIA1 levels and at Chania starting in IIIB early and continuing into IIIC; although the pottery looks Italian, analysis of some pieces shows it to be local. Presumably, then, some pots at least were made by resident Italians for their own use, rather than imported from Italy. The same contexts at Chania have yielded wheelmade Gray ware cups and kylikes, some with highswung handles. The source of this ware has not been determined, but it may not be Italy; similar pieces have been found in Anatolia in chamber tombs at Müskebi near Halikarnassos.

The LM II-IIIA period also marks significant

${ }^{491}$ Kommos III, 157 lists Cypriot pottery in IIIA levels at Kommos: 22 White Slip milkbowls, two Base Ring juglets and a bowl, a White Shaved juglet, two Plain White Wheelmade pithoi, and an amphora. V. Karageorghis, "Some Reflections on the Relations between Cyprus and Crete during the Late Minoan III B Period," in Karageorghis (supra n. 206) 199. Popham, in Karageorghis (supra n. 477) 183.

${ }^{492}$ H. Catling, quoted in Jones 589, 593; G. Cadogan, "Cyprus, Minoan Pottery, Trade and Colonization," in Zerner and Zerner (supra n. 302) 91-99, esp. 93; J.H. Crouwel, "Mycenaean Pictorial Pottery from Cyprus in Oxford," OJA 10 (1991) 45-53; Hankey (supra n. 303) 101-10.

${ }^{493}$ V. Hankey, "Crete, Cyprus, and the South-East Mediterranean, 1400-1200 B.C.," in Karageorghis (supra n. 206) 144-57 lists LM IIIA from Akko tomb 3, Tell Abu Hawam, Khirbet Judur, and Minet el Beida; and IIIAl from Gurob and Minet el Beida. The only Canaanite from East Crete in LM IIIA is a flask and some sherds from Pseira, House DA (Betancourt and Davaras, in Cretan Studies [supra n. 34]). Kommos, however, has yielded much more in IIIA levels; Kommos III, 160-61 lists 14 South and 6 North Canaanite jars, and four Egyptian jars, five storage jars, two flasks, and two closed vessels. J. Shaw, “Two Three-Holed changes in Egypt's relations with its neighbors, in which the inhabitants of the Aegean clearly played a part. Following the expulsion of the Hyksos, the Egyptians had embarked on the creation of an empire in Syria-Palestine that eventually stretched to the upper Euphrates. By the mid-15th century, Aegean merchants would have been trading at Syrian ports, some of them under Egyptian control. It is not surprising, therefore, that we find Aegean natives, occasionally labeled Keftiu, represented in Egyptian tombs at Thebes, along with Syrians and other foreigners. ${ }^{496}$

Although the Keftiu had vanished from Egyptian paintings by the time of Tuthmosis IV, a trade in textiles from the Aegean seems to have continued to influence decorative patterns, which often survive painted on the ceilings and walls of tombs and palaces. Ceilings in the tomb of Senenmut included meander patterns or interlocking running spirals with dotted centers, alternating with rosettes, all of which find close parallels in Minoan decorative patterns. ${ }^{497}$ These continue until at least the end of the 18th Dynasty. A well-known ceiling from the palace of Amenhotep III at Malkata (West Thebes) includes running spirals with dotted centers alternating with bucrania supporting rosettes.

The long reign of Amenhotep III overlaps with much of LM IIIA1-2, during which Crete, not the mainland, receives the lion's share of Egyptian imports. ${ }^{498}$ The discovery of LH IIIA2 pottery and a few incipient IIIB sherds at Akhenaten's short-lived capital of Amarna fits what we know of the reigns

Stone Anchors from Kommos, Crete," IJNA 24 (1995) 279-91.

${ }^{494}$ Mochlos: $A R 40$ (1994) 81. Mallia, Quartier Nu: $A R$ 39 (1993) 76. Ayios Stephanos: Jones 424. Cyprus: Jones and Day (supra n. 200) 263; Karageorghis (supra n. 491); Popham, in Karageorghis (supra n. 477) 187; E. Hallager 1988 (supra n. 412) fig. 3, caption. Italy: L. Vagnetti, "Ceramiche del Tardo Minoico III rinvenute in Italia," in M. Liverani, A. Palmieri, and R. Peroni eds., Studi di palentol. ogia in onore di Salvatore M. Puglisi (Rome 1985) 825-32. Sardinia: M.L.F. Ceruti, L. Vagnetti, and F. Lo Schiavo, "Minoici, Micenei e Ciprioti in Sardegna nella seconda meta del II millennio a.C.", in Balmuth (supra n. 200) 7-38, esp. 17; B.P. Hallager, "Crete and Italy in the Late Bronze III Period," AJA 89 (1985) 293-305; and Jones and Day (supra n. 200).

${ }^{495}$ Kommos: Kommos III, 164-68; Chania: B.P. Hallager (supra n. 494) and personal communication.

${ }_{496}$ Rehak (supra n. 203); P. Rehak, "Aegean Natives in the Theban Tomb Paintings," in Aegean and Orient; Matthäus (supra n. 456).

497 P.F. Dorman, The Tombs of Senenmut (New York 1991) col. pls. 20b, 27b-c, 28, 60 fig. 13.

${ }^{498}$ Cline, passim. 
of the immediate successors of Amenhotep III; Amarna was probably abandoned during the reign of Tutankhamen. Inscribed objects dating to the reign of Amenhotep III have been found both on Crete and the mainland, and the "Aegean itinerary" on a statue base in Amenhotep's funerary complex at Kom el-Hetan and faience plaques at Mycenae support the notion that Egypt was acknowledging the increasing importance of the mainland centers.

\section{Religion}

During the Final Palatial period, marked changes in Minoan religion take place, following what appears to be a massive rejection of the Neopalatial religious-political system at the end of LM IB. While there is evidence for both continuity and change, the following five main developments may be noted in particular. First, as noted above, the production of certain types of palatial prestige ritual objects ceases after the LM IB destructions. Some of these objects are now appropriated for tombs. Tripod offering tables of stucco or clay continue, including painted examples, but these are also sometimes found in tombs. ${ }^{499}$ Second, certain Neopalatial symbols of possible religious significance become un. common or disappear: inscribed stone offering tables are no longer produced (though some are reused), stepped stands for double axes and the sacral knot seem to vanish, and stone and stucco horns of consecration are replaced by painted examples on pottery and terracotta larnakes.

Third, cult equipment on Crete is increasingly manufactured of terracotta, a trend that continues to the end of the Bronze Age. The house or sanctuary models of the Proto- and Neopalatial periods are superseded by "hut models." Plastic horns of consecration are modeled on some stands. ${ }^{500}$ Tubular

499 The ears and inlays from a bull's head rhyton in the Tomb of the Double Axes at Knossos: Evans (supra n. 148) 52 fig. 70. A trapezoidal base (for a double ax?) was deposited in a shaft grave at Knossos: Hood 1958-1959 (supra n. 425). A marble triton comes from a Warrior Grave at Kalyvia: $C M$ pl. 115 (below). Tripod offering tables: $B C H$ 102 (1978) 836 fig. 8, from Mallia. Katsamba tombs: Alexiou (supra n. 158) pl. $12 \alpha-\beta$, pl. $26 \beta$.

${ }^{500}$ J.C. Poursat, "Malia au MR III," 6th CretCong A2 (1990) 160, pl. 28d.

${ }^{501}$ Zoomorphic and anthropomorphic figurines: Rethemiotakis (supra n. 272). From habitation sites come others, like the elaborately painted figurines of LM II date from the Unexplored Mansion at Knossos (Popham et al. [supra n. 5] pl. 159.5), the figurine of LM II-IIIA date from Poros painted with a Linear A inscription, the LM IIIA2 figurine of a kourotrophos who holds her child aloft, and the upper stands, which may have had a cultic use in the Neopalatial period, now become larger and more elaborate. With the addition of plastic surface decoration resembling snakes, these are now referred to as snake tubes, though they may have no connection with these animals. There is also a resurgence in the use of terracotta for zoomorphic and anthropomorphic (especially female) figurines, and these are now found in several locations, including shrines connected with habitation areas. It has not been established whether these figurines represent goddesses or votaries, but they have an important role in the small shrines, where they are often set on stands or benches facing the doorway to the room. Many of the female figurines have upraised arms, a gesture of uncertain meaning. A seminal study by Alexiou labeled this type the "Minoan Goddess with Upraised Arms" (MGUA). ${ }^{501}$ Although these are especially characteristic of the Postpalatial period (see below), they originate in the Final Palatial period or earlier. Their gestures may derive from the upraised arms of Neopalatial faience figurines or of the women on sealstones who wear the "snake frame" headdress.

The mainland class of psi, phi, and tau figurines is introduced into Crete in LM IIIA2, a sign of Mycenaean presence. ${ }^{502}$ The IIIA2-B period also sees the introduction of large wheelmade bovid figurines. Moldmade bovid rhyta had existed in the Neopalatial period, but these seem to die out after the end of LM IB. The concept of the bull rhyton is revived, perhaps under Mycenaean influence, but the rhyton is now much less naturalistic in form.

Fourth, new types of cult practice become visible, particularly in the area of funerary cult. As we have seen, painted terracotta larnakes introduce a new iconography, and the painted sarcophagus from Ayia Triada provides one of the most important, if de-

half of a naturalistic female figurine from Quartier $\mathrm{Nu}$ at Mallia (Driessen and Farnoux [supra n. 468] pl. V.3). The so-called Shrine of the Double Axes in the Knossos palace, Gesell 90-92, was dated by Evans to LM IIIB, but its female figurines may be of LM IIIA date. Other female terracotta figurines were found in the Little Palace (Gesell 93-94), in a domestic shrine at Kannia near Phaistos (Levi [supra n. 52] 253-64). Part of the head of a terracotta figurine, from a figure originally more than $1 \mathrm{~m}$ tall, was found on Mt. Juktas (Prakt 1975, pl. 267 $\alpha$ ). MGUAs: S.

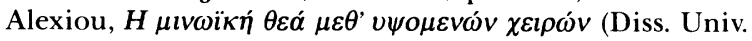
of Athens 1958), and published separately in CretChron 12 (1958) 179-299. Photographs: CM pls. 128-31 (Gazi), 135-37 (Karphi).

${ }^{502}$ E. French, "The Development of Mycenaean Terracotta Figurines," BSA 66 (1971) 101-87; French (supra n. 442). 
bated, glimpses into the Minoan view of the afterlife during this period. A major development of the Final Palatial period is the evidence for bull sacrifice; it is possible that the killing of the animal now becomes the final feature of the Minoan bull-games, perhaps under Mycenaean influence. It may be sig. nificant too that the bull sacrifice is attested at exactly the moment when the new iconographic topos of the Minotaur appears on seals. If the minotaurs represent men in masks, they may be appropriating some of the powers associated with the bull for symbolic, even shamanistic, purposes. ${ }^{503}$ Women still played an important role in religion, however, as the Knossos Procession Fresco, Ayia Triada sarcophagus, and Archanes Tholos A all demonstrate.

Fifth, it is hardly surprising that there is slight evidence for a general reuse of peak sanctuaries in LM II-III, ${ }^{504}$ generally at peaks that are close to habitation sites. Continuity of cult activity occurs at Juktas and Kato Syme, and although prestige dedications decline, they are nevertheless still present, ${ }^{505}$ and sherd material indicates that cave cult continues as well. A new feature is the emphasis on small "house shrinẹs" or "town shrines." Some of these replace Neopalatial ritual areas, like the "fetish shrine" in the Little Palace from a remodeled lustral basin, while others appear to be new creations (the Shrine of the Double Axes in the Knossos palace; the freestanding town shrine at Ayia Triada; and the Gournia town shrine). The use of piers in the Shrine of the Double Axes and the piers and floor fresco at Ayia Triada may be deliberate attempts to recall Neopalatial forms. ${ }^{506}$ A LM IIIA2-B house shrine in Building 7

${ }^{503}$ Sakellarakis (supra n. 383); Younger (supra n. 254) 518-21. N. Schlager, "Minotauros in der ägäischen Glyptik?" CMS Beiheft 3 (Berlin 1989) 225-37. A LM IIIA larnax found at Mochlos is painted on the interior with two standing figures, one seemingly wearing a mask with pointed ears: Soles and Davaras 1996 (supra n. 33). For a new seal depicting the Minotaur, found at Midea on the mainland, see Demakopoulou et al. 1994 (supra n. 122) 32-33 figs. 43-44. For masks, cf. C.F. Klein, "Masking Empire," Art History 9 (1986) 135-67.

${ }^{504}$ J.F. Cherry, "Generalisation and the Archaeology of the State," in D. Green, C. Haselgrove, and M. Spriggs eds., Social Organisation and Settlement (Oxford 1978) 429, fig. 1; Peatfield (supra n. 359).

${ }^{505}$ Sapouna-Sakellaraki (supra n. 41) 72-73 figs. 6-7; $A R$ 36 (1990) 71. Finds include wheelmade bovids. Juktas: $A R$ 36 (1990) 71; Kato Syme: $A R 36$ (1990) 72. LM II pottery has been discovered at Juktas, and a type Gi sword decorated with spirals and semicircles was dedicated at Kato Syme: A. Lembesi, ArchEph 1981, 1-24, esp. 15, pl. 2.

${ }^{506}$ The Ayia Triada shrine has a vivid but crude floor fresco with marine motifs that include dolphins, rockwork, at Palaikastro included pithoi, a terracotta bull's head rhyton, triton shells, cylindrical stands, stalactites, and benches. A distinctive feature of the new small shrines is the bench at the back of the room, used to support MGUAs, along with other figurines and offerings.

Finally, the Linear B texts shed light on the religious concerns of the major administrative centers. Most of the Linear B religious texts from Knossos concern amounts of oil or honey going to various divinities: Ares, Diktaian Zeus, Enyalios, Eileithyia, Erinyes, Pan (?), Paian, and Poseidon. The Pantheon (pa-si-te-o-i, in the dative) is frequently mentioned, at Amnisos, at Au-ri-mo, and at a locality not specified and probably therefore Knossos. At Chania there is mention of a shrine of Zeus as well as the god Dionysos for the first time. 507

At least one sanctuary and possibly more existed at Amnisos. The divinities mentioned there are Eileithyia, Ares, probably Poseidon, and frequently the Pantheon. Of the religious administration, there is mention of a couple of shrines, the da-da-re-jo (the Daidaleion), the da-pur-ri-to (Labyrinth), and the shrine to Diktaian Zeus. There is a qe-ra-si-ja (Gerousia?) at a locality not mentioned (probably Knossos), as well as at Amnisos and at Au-ri-mo; but only one type of priestess is listed, the Priestess of the Winds located at three sites, *47-da, Au-ri-mo, and U-ta-no (Fp 1 and 13), and only one priest is mentioned, that at $d a * 83-j a\left(\mathrm{Fp} \mathrm{363).}{ }^{508}\right.$

More controversial have been the mentions of a da-pu $u_{2}$-ri-to-jo po-ti-ni-ja and a-ta-na-po-ti-ni-ja. Many scholars have assumed po-ti-ni-ja is the goddess Pot-

and a bold red octopus: Immerwahr 102 and n. 14. Hood's date of LM I is too early: Hood (supra n. 157) 71, 249, $n$. 134; Hirsch (supra n. 80) 10-11, pl. I; E.S. Hirsch, "Another Look at Minoan and Mycenaean Interrelationships in Floor Decoration," AJA 84 (1980) 459-61.

${ }_{507}$ J.T. Killen, "Piety Begins at Home," in P. Ilievski and Ljiljana Crepajac eds., Tractata Mycenaea (Skopje 1987) 163-78, esp. 164. Respectively, a-re (KN Fp 140); di-ka-ta-jo di-we (Fp 1, 7?); e-nu-wa-ri-jo (V 53); e-re-u-ti-ja (Gg 705); e-rinu-we (Fp 1; V 53); pa-de (Fp 1; Ga 953); pa-ja-wo-ne (Fp 354; $\mathrm{V}$ 53); and po-si-da-o-ne (Gg 705?, 717; V 53); the Pantheon (pa-si-te-o-i: Fp 1, 5, 6, 13, 14, 16; Ga 953). Chania: KH Gq 5. Hallager et al. (supra n. 468). M.S. Ruiperez, "The Mycenaean Name of Dionysos," in A. Heubeck and G. Neumann eds., Res Mycenaeae (Göttingen 1983) 408-12.

${ }^{508}$ S. Hiller, "The Administration of Minoan Sanctuar. ies by the Mycenaean Palace at Knossos," in A. Farnoux and J. Driessen eds., La Crète mycénienne (forthcoming). Killen (supra n. 486) 173: a shrine to Diktaian Zeus in central Crete and near Knossos accords well with Strabo's quote

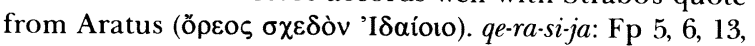
16, 48. S. Hiller, "Minoan qe-ra-si-ja," $T A W$ I, 675-79. 
nia, but at Pylos she is occasionally mentioned in connection with other places (e.g., Elis? in PY Fr 1228) and is occasionally paired with the wanax of Pylos himself (e.g., Fr 1235), the two forming the wa-naso-i. ${ }^{509}$ If Atana is the Minoan version of Utano, a place-name in the Tylissos group, located in northwestern Crete and connected with ancient Tanos, ${ }^{510}$ then po-ti-ni-ja may simply be a "chief priestess" there as well as at the Labyrinth. Two Knossos tablets (KN Ga 1058 and Od 696) mention a festival, the te-o-

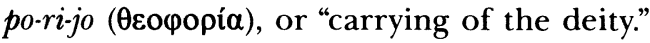

\section{POSTPALATIAL CRETE (LM IIIB LATE-SUBMINOAN)}

\section{Sites and Architecture}

Both the beginning and the end of the Postpalatial period have proved difficult to define, except by the apparent loss of literacy on Crete. ${ }^{511}$ On present evidence, there were no palatial administrations anywhere on Crete from LM IIIB late through the end of the Bronze Age. Some inscribed stirrup jars in late IIIB contexts at Quartier Nu, Mallia, could simply be holdovers. Similarly, scholars have debated over how to define the end of the Bronze Age on Crete. Is it marked by the latest IIIC pottery, or does a Subminoan phase exist as an independent period transitional to the Protogeometric/Early Iron Age?512

${ }^{509}$ da-pu - -ri-to-jo po-ti-ni-ja: Gg 702. L. Godart, "Il labirinto e la potnia nei testi micenei," RendNap 50 (1975) 141-52. a-ta-na-po-ti-ni-ja: V 53. C. Milani, "Atena e la Potnia micenea," in M. Sordi ed., Politica e religione nel primo scontro tra Rome e l'Oriente (Milan 1982) 29-42. po-ti-ni-ja: for a recent study,

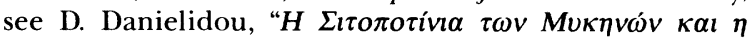

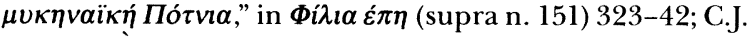
Ruijgh, "À propos de mycénien po-ti-ni-ja-we-jo," SMEA 4 (1967) 40-52; M.G. Rousseau, Les mentions religieuses dans les tablettes mycéniennes (Rome 1968) 189; S. Hiller, "Wanasoi tonoeketerijo," Minos 10 (1969) 78-92; J.C. van Leuven, "Mycenaean Goddesses Called 'Potnia,' Kadmos 18 (1979) 112-29; J.T. Hooker, Mycenaean Greece (London 1976) 208; S. Hiller, "Mykenische Heiligtümer," in Sanctuaries 122-24; M. Del Freo, "Pa-sa-ro, wa-na-so-i e il valore dei sillabogrammi [s-] e [z-] in miceneo," SMEA 26 (1987) 151-90; F.A. Jorro ed., Diccionario micenico II (1993) s.v. po-ti-ni-ja.

${ }^{510}$ K.T. Witczak, "Notes on Cretan Place-Names in the Linear B Tablets," Kadmos 31 (1992) 161-62. C. Buondelmonti (travels A.D. 1415; included in Cornelius, Creta Sacra I.123 [1755]; and quoted by S.G. Spanakis, K $\rho \eta \dot{\tau} \eta$ B [Herakleion n.d.] 371, s.n. Távoৎ) gives the name as an alternative for Apokoronou, the fort on the Bamos peninsula.

511 Basic bibliography on this period includes S. DegerJalkotzy, "The Post-Palatial Period of Greece," in V. Karageorghis ed., Cyprus in the 11th Century B.C. (Nicosia 1994) 11-29; K. Nowicki, "Topography of Refuge Settlement in Crete," JRGZM 34 (1987) 213-34; Nowicki, "The History and Setting of the Town at Karphi," SMEA 26 (1987) 235-50;
Despite the nebulous boundaries to this period, there is general agreement that the picture of Postpalatial Crete is vastly different from the scenario envisioned earlier by Evans and Pendlebury of de pressed refugee populations hiding in the mountains. ${ }^{513}$ Nevertheless, it is clear that the disappearance of palatial administration after LM IIIB early marks a watershed on Crete. Up to this point, there had been evidence across the island from both habitation and burial sites. The most common Postpalatial site, however, is the tomb, with few habitation sites known for the latter part of LM IIIB and C. While some tholoi appear fairly canonical, most in the Postpalatial period are small, with diameters and heights of about $1 \mathrm{~m} \cdot{ }^{514}$ They contain only a few burials, sometimes in larnakes.

The diminishing number of settlements from LM IIIB late seems to indicate a shrinking of population. In IIIC, a progressive movement away from the shore may have occurred, though what this means precisely is still being debated. Sites toward the eastern end of the island, like Kavousi Vronda and Kastro, Vrokastro, and Vasiliki Kephala, however, are near the coast and have good views of the sea, as does Karphi. It may be, as Watrous suggests, that piracy forced the move inland and to higher elevations, as well as

B.J. Hayden, "Fortifications of Postpalatial and Early Iron Age Crete," $A A$ 1988, 1-21; L. Godart and Y. Tzedakis, "La Crète du Minoen Récent III B à l'époque géométrique," in Musti et al. (supra n. 363) 187-95; H. van Effenterre, "Développements territoriaux dans la Crète postminoenne," in Musti et al. (supra n. 363) 197-206; G. Rizza, "Priniás in età micenea," in Atti (supra n. 429).

${ }^{512}$ For discussions of Subminoan pottery, see M. Tsipopoulou, "Ceramica dei periodi subminoico geometrico ed orientalizzante," in M. Rocchi and L. Vagnetti eds., Seminari, anno 1990 (Rome 1991) 137-64; M. Popham, "The SubMinoan Pottery," in L.H. Sackett ed., Knossos: From Greek City to Roman Colony II.1 (BSA Suppl. 21, Athens 1992) 59-66. A related problem is whether "Submycenaean" exists: J.B. Rutter, "A Plea for the Abandonment of the Term "Submycenaean," TUAS 3 (1978) 58-65.

513 J.D.S. Pendlebury, The Archaeology of Crete (London 1939) 303: "We seem to be back in the Neolithic Period with its life of terror."

${ }^{514}$ Kanta 322: large, regular tholoi include Stylos Apokoronou (Kanta 235). Large tholoi with rectangular chambers: Malame, Phylaki, Achladia (supra n. 431). Small tholoi: Kanta 322: Panayia Pediadas (Kanta 74-75), Erganos Pediadas (75-76), Dhamania Monophatsiou (79), Karphi Lasithiou (121), Vasiliki in Ierapetra (146), Khamaizi Siteias (176), Praisos Siteias (179); G.C. Gesell, L.P. Day, and W.D.E. Coulson, "Tombs and Burial Practices in Early Iron Age Crete," Expedition 32:3 (1990) 22-30. 
provided the various imports one sees at such sites as Karphi (Cypriot pottery and bronzes and Italian pins). ${ }^{515}$

Some sites look prosperous. At Chania new houses are built and the Mycenaean settlement is extended farther up the Kastelli hill. ${ }^{516}$ At least one import from Cyprus and local imitations of Italian handmade burnished ware are known. After a heavy fire destruction at the end of LM IIIB, some reoccupation took place in LM IIIC, with reuse of rooms and new construction. Though there are few finds, local imitations of Gray wares are among them. No major destruction occurs at Chania in LM IIIC and the site is quietly abandoned before reoccupation in the Late Geometric. Excavations conducted by a Greek-Italian team in western Crete in 1989 and 1990 have revealed a new LM IIIC settlement site at Sybrita, with pits containing bones, traces of burned material, and pottery (coarse and fine wares). ${ }^{517}$

Quartier $\mathrm{Nu}$ and several other areas at Mallia experience a destruction by fire in LM IIIB early, followed by an orderly cleanup and reoccupation. A destructive fire at the end of IIIB and scanty occupation in IIIC follow, with an abandonment before the end of the period. Gournia's Mycenaean buildings west beyond the ravine may date to LM IIIB; at least one Mycenaean burial took place in the earlier town. Along the coast east of Herakleion thriving settlements existed, with houses at Katsamba, Poros, and Gouves.

Some sites, however, disappear in LM IIIB: Pseira is abandoned early, Chondros is destroyed by fire and abandoned, and Kommos is virtually deserted

\footnotetext{
${ }^{515}$ A summary of the settlement history in the Lasithi plain makes the trend toward a shrinking population clear (L.V. Watrous, An Archaeological Survey of the Lasithi Plain in Crete from the Neolithic to the Late Roman Period [Diss. Univ. of Pennsylvania 1975]): in the Neolithic period, 15 openair sites and caves; in EM II, six or seven hamlets with cem. eteries; in MM I, the previous hamlets plus three or four new sites; in MM III, 11 large settlements altogether; in LM I, nine settlements; in LM IIIA-B, only three of the previous sites continue plus two more; in LM IIIB late, only Karphi is a major settlement, plus six smaller sites; at the end of the Bronze Age, only Papoura. For a shift away from the shore, see V.R.d'A. Desborough, "Crete in the First Half of the Twelfth Century B.C.," 3rd CretCong (1973) 62-69. Piracy: Watrous (supra) 326.

${ }^{516}$ E. Hallager 1988 (supra n. 412); AR 42 (1996) 47.

${ }^{517}$ N. Metaxa Prokopiou, "Sybrita Amariou," in Musti et al. (supra n. 363) 373-401; Metaxa Prokopiou, "H

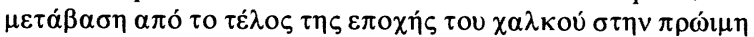

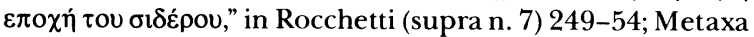

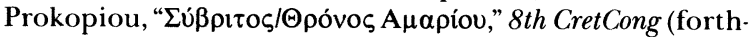
coming); L. Rocchetti, "Sybrita," in Atti (supra n. 429).
}

toward the end of IIIB early though small amounts of late IIIB and C pottery have been found at the site. ${ }^{518}$ Ayia Triada has LM IIIB pottery but not, apparently, LM IIIC. The South-West houses at Knossos are abandoned, and LM IIIC Knossos is known primarily from tombs.

While a few sites are abandoned in LM IIIC (e.g., Stavromenos-Chamalevri), some new sites are also founded. Those at high elevations are well known: Karphi and Kavousi Vronda are first settled early in the period, Prinias and Chalasmenos are settled by the end of the period, and Arvi and Katalimata sometime in IIIC. Some sites lower down, however, also thrive: a house in Katsamba contained iron in its second phase and Phaistos is well settled into the Subminoan period. A couple of sites seem to move their populations late in LM IIIB or in LM IIIC: Ayia Pelagia may move to Kastrokephala, which is surrounded by a fortification wall, late in IIIB; Zakros has little if any LM IIIB pottery, but the Lenika peak in the adjacent Gorge of the Dead is inhabited in LM IIIC. Palaikastro suffers a fire late in LM IIIB and the population apparently moves to the acropolis Kastri, overlooking the sea for LM IIIC.

In recent years, intensive excavation and survey work by several teams in the Gulf of Mirambello and Isthmus of Ierapetra have revealed important evidence for the final phases of Bronze Age Crete: Kavousi (Vronda and Kastro), Vrokastro, Chalasmenos and Katalimata, and, at the edge of Lasithi, Karphi. Another large IIIC habitation site has been identified by survey at the peak of Profitis Elias south of Episkopi. ${ }^{519}$ Importantly, many of these late commu-

\footnotetext{
518 Kommos III, 146-47.

519 Kavousi: Atlas 120-24; W.D.E. Coulson et al., "Excavations on the Kastro at Kavousi," Hesperia 66 (1997) 315-90; Day, "Early Iron Age Architecture at Kavousi," in 6th CretCong A2 (1990) 173-84; AR 36 (1990) 73-74; AR 37 (1991) 71-72; AR 38 (1992) 64; AR 41 (1995) 65-67; AR 42 (1996) 46. Vrokastro: Atlas 286-91; B.J. Hayden, “Terracotta Figures, Figurines, and Vase Attachments from Vrokastro, Crete," Hesperia 60 (1991) 101-44; Hayden et al. (supra n. 7); $A R$ 38 (1992) 67-68. Chalasmenos and Katalimata: D.C. Hag. gis and K. Nowicki, Hesperia 62 (1993) 303-37; Coulson and M. Tsipopoulou, "Preliminary Investigations at Halasmenos, Crete, 1992-93," Aegean Archaeology 1 (1994) 65-97; Nowicki, "Kataleimata," in Coulson and Tsipopoulou (supra) 94-97; AR 41 (1995) 65; AR 42 (1996) 45. Karphi: Atlas 117-19; Nowicki, "History, Topography and Economy of Karphi," in Thomas (supra n. 390) 25-32; Nowicki (supra n. 359) 43-46; Day, AJA 101 (1997) 348 (abstract). A small SubminoanProtogeometric cemetery at Karphi Pediados-Mnemata: $A R 37$ (1991) 71; AR 42 (1996) 46. Profitis Elias near Episkopi: $A R 41$ (1995) 65.
} 
nities are preceded by evidence of early habitation, generally Neolithic, EM II, and MM II. The late settlements thus are not new foundations, but rather reestablishments of previously existing sites.

Kavousi actually consists of two settlement sites initially explored in 1900, a lower one at Vronda (380 masl) and the upper one at the Kastro (700 masl), separated by a short walk. Like many sites in this area, Vronda had Neolithic and Early Minoan remains (EM IIB-III) and extensive MM II habitation. In LM IIIC the area was reoccupied, and at least one building (E) was probably abandoned at the end of IIIC. Room 1 in Building $\mathrm{E}$ contained pithoi in different shapes and decoration. A Late Geometric cemetery is at Vronda. At Kavousi Kastro nearby, three main phases have been identified: I (transitional from IIIB-C), II (mid-IIIC), and III (late IIIC, contemporary with Vronda). Kastro thus is important because it appears to give a complete habitation sequence through LM IIIC. Phase V represents a transition from LM IIIC to Protogeometric.

Watrous has argued persuasively for paired villages, one below the elevation limit for olive trees (600-800 masl) and one above in the mountainous regions suitable for herding; such paired sites would include Kavousi Vronda and Kastro. In addition, Nowicki's indefatigable mountain surveys across the island have revealed a more horizontal dimension; sites at high altitudes often work together to guard passes and oversee approaches to the upland valleys. ${ }^{520}$ Habitation at these sites is not limited to the Postpalatial period, but recurs throughout Crete's history.

The new excavation of Vasiliki Kephala under the direction of Eliopoulos is also changing our perceptions of this period. ${ }^{521} \mathrm{~A}$ small tholos tomb had been excavated by Seager south of the site in 1906 . Although naturally defensible, Kephala occupies a relatively low-lying site (213 masl) on the flat-topped ridge just above Vasiliki, far lower and more accessible than some of the other Isthmus sites. More importantly, the location of Kephala gives it direct control over trade and movement of people north and south over the Isthmus, and a direct line of sight to contemporary sites like Kavousi Kastro and Vronda, and Chalasmenos. Excavations since 1994

${ }^{520}$ Watrous (supra n. 515) 322-27. E.g., K. Nowicki, "Settlements of Refuge in Crete," in Schiering (supra n. 114) 83-87; Nowicki, "Investigations in the Cretan Mountains," ArcheologiaWar 39 (1988) 189-98; Nowicki, ArcheologiaWar 44 (1993) 95-101.

${ }^{521}$ We are grateful to the excavator, Theodoros Eliopoulos, for graciously giving us a tour of the site in June 1996, and for providing the following information. have already revealed a substantial settlement, LM IIIC to Protogeometric. The Dark Age settlement was large, occupying the whole flat top (ca. $230 \mathrm{~m}$, north-south) of Kephala hill. Parts of 10 buildings, in varying degrees of preservation, have been located. One, Epsilon, has been completely excavated and seems to be unique for the period; a temple complex $(17 \times 25 \mathrm{~m})$, it consists of eight rooms grouped in three wings, each of which may have served a specific cult function. In the south wing, cult figures and equipment were found in situ on benches. Parts of at least five MGUAs have been recognized, one of them enthroned (H. $44 \mathrm{~cm})$, as well as snake tubes, fenestrated stands, and votive backing plaques. In the main room of the central wing two axial wooden columns rested on stone slab bases framing a central hearth. In an attached magazine an heirloom seal with a cow suckling a calf was found. The northern wing consists of large rooms, one of which (E3) may have seen important cult activity (fig. 8). It has low benches around the walls and in the middle a low stone platform incorporating an upright unworked stone, possibly an altar with baetyl.

At Chalasmenos, traces of a small settlement have been excavated since 1993 by a joint Greek-American team. On either side of a rocky outcrop some preserved house walls incorporate the natural bedrock, and individual stones about $0.5 \mathrm{~m}$ in diameter pre. sent worked interior and exterior faces. Rooms are small, with doors generally at the ends of their short sides. Roofs consisted of wooden beams covered by hard-packed waterproof orange-yellow clay, with floors of hard-packed earth. In some rooms, flat stones on the floor served as vessel stands and hearths consisted of small stones. A small tholos, A, is located nearby, built of medium and large blocks in seven courses. It held the bodies of five individuals, four adults and one adolescent. ${ }^{522}$ Though short by today's standards $(\mathrm{H}$. men ca. $168.5 \mathrm{~cm}, \mathrm{H}$. women $145.6 \mathrm{~cm}$ ), they were muscular and robust. A kalathos from Tholos A has a nearly exact parallel from the settlement, and both may have been made by the same local potter.

Some architecture survives from the LM IIIB late and IIIC periods. ${ }^{523}$ Where the terrain permits, square house plans seem to be common: Chania in

522 L. Little, "The Burials in Tomb A at Halasmenos," in Coulson and Tsipopoulou (supra n. 519) 87-91. Dimensions of the tholos: D. $1.60 \mathrm{~m} ; \mathrm{H} .1 .40 \mathrm{~m}$; entrance W. $0.90 \mathrm{~m}$.

${ }^{523}$ B.J. Hayden, "Aspects of Village Architecture in the Cretan Postpalatial Period," Aegaeum 6 (1990) 203-13; Hayden (supra ns. 414, 416); and M.S. Mook, The Northwest Building: Houses of the Late Bronze and Early Iron Ages on the Kastro at Kavousi, East Crete (Diss. Univ. of Minnesota 1993). 


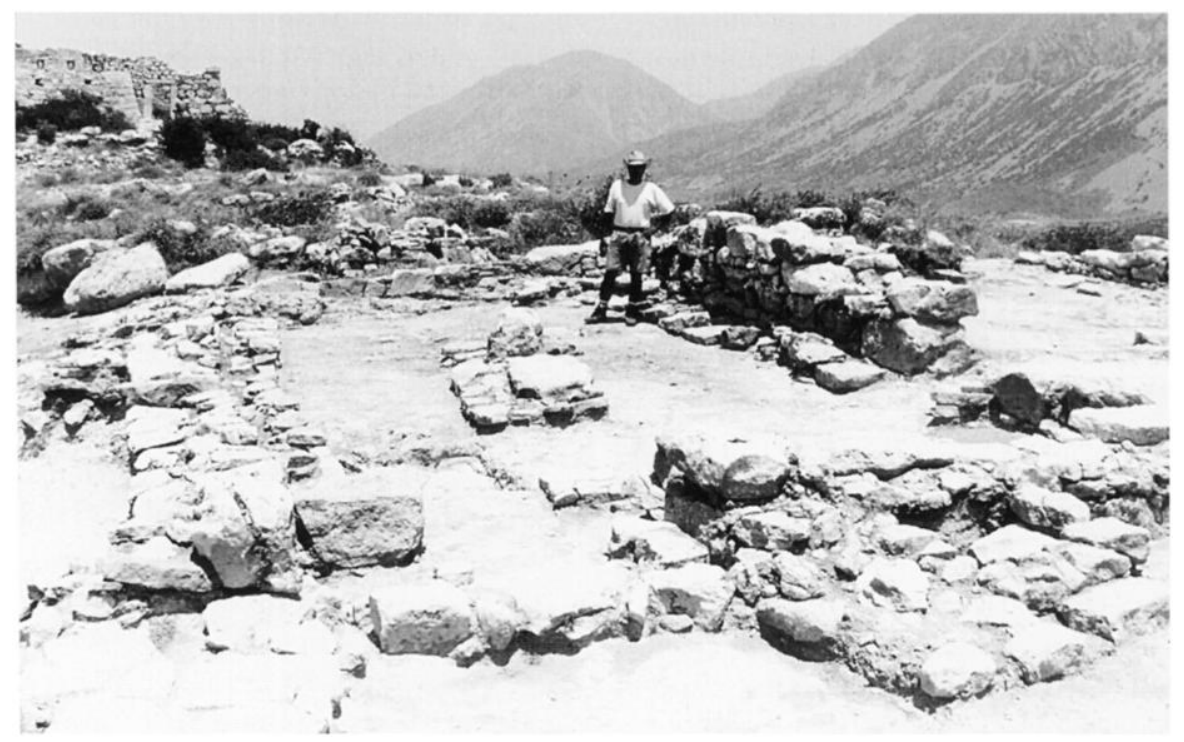

Fig. 8. View of Vasiliki Kephala, room E3. (Courtesy T. Eliopoulos)

IIIB; and Kavousi Vronda, Karphi, and Chalasmenos (as far as can be judged) in IIIC. Where the steep terrain limits the accessible area, as at Kavousi Kastro, Vrokastro, Karphi, and Katalimata, long rectangular houses with rooms in rank occupy narrow terraces. Chania, Karphi, and Kavousi Vronda provide some idea of a village plan: units clustered closely together, in no rigidly maintained alignment, separated by dog-leg alleys. An occasional plateia breaks the claustrophobia, allowing for outside work areas and gatherings. The result is not unlike modern Cretan traditional villages. Walls at Chalasmenos were preserved up to $1 \mathrm{~m}$ in height and consisted of carefully laid limestone blocks held together with a mortar of mud, as at Vronda. One oddity, the absence of an apparent doorway, has commonly led to the assumption that these rooms are basement rooms, but in early modern villages in Crete doorways are often raised above the level of the exterior road or alley and approached by a short flight of steps that hugs the exterior wall.

Important buildings may be isolated and rectangular with a central rectangular hearth flanked by two wooden columns on bases (Chania, Vasiliki Kephala). This form later becomes the Archaic Cretan temple like those found at Kommos and Prinias. The LM IIIB and C temple, however, seems to consist of

${ }^{524}$ Hayden (supra n. 511); K. Nowicki, "A Dark Age Refuge Centre near Pefki, East Crete," BSA 89 (1994) 235-68; Nowicki, "Arvi Fortetsa and Loutraki Kandilioro," BSA 91 (1996) 253-85.

525 For a survey of Final Palatial and Postpalatial pottery, see Popham, in Evely et al. (supra n. 1) 89-103. See also M.C. Shaw, "Two Cups with Incised Decoration from Kom- a building that is rectangular (Kavousi Vronda) or square (Vasiliki Kephala) with one or more benches on which to set MGUAs, and a storage room at one end.

A special type of site is the so-called refuge settlement, placed high atop a mountain and surrounded by a cyclopean fortification wall.524 These sites, however, are not limited to this period only; as noted above, the "refuge" fortification wall on Juk tas may be Neopalatial.

Art

A significant, and as yet unresolved, problem is the ceramic chronology and phasing of LM IIIBC. ${ }^{525}$ Nevertheless, excavators on Crete are in general agreement on two points: IIIB-C pottery shows innovations that indicate that it is not simply trailing behind developments on the mainland, and the stylistic sequences worked out for the mainland by Furumark and others do not hold for Crete. Current research is directed to establishing these later sequences. Groundbreaking work in the former area took place at the conference on LM III pottery held at the Danish Institute in Athens in 1994. ${ }^{526}$

The most common IIIC shapes are stirrup jars, kraters, and bowls, continuing the trend toward fewer shapes in use. Painted decoration becomes sim-

mos, Crete," AJA 87 (1983) 443-52; and P. Sotirakopoulou, "The Chronology of the 'Kastri Group' Reconsidered," BSA 88 (1993) 5-20.

${ }^{526}$ Hallager and Hallager (supra n. 5); we are grateful to the editors for allowing us to read the manuscript before publication. 
plified and does not fill the entire surface of the pot. Close Style pottery is present on Crete throughout IIIC; it does not develop within it. A diagnostic feature of IIIC stirrup jars is a bump atop the "spool" of the handle, with the "spool" itself added separately, not pinched out of the clay of the vessel. One unusual IIIC shape is the lid, which often has piecrust decoration and burning on the underside. These may be fire-dampers. Pictorial vase painting, which continues into the Early Iron Age (see below), has attracted attention, although major studies have been conducted so far only on pictorial larnakes. Coarse ware pottery is also finally receiving serious consideration. ${ }^{527}$

After LM IIIB early, many art forms become defunct. No frescoes, hard stone seals, or stone vases seem to be manufactured in this period or later, and it is doubtful that faience or ivory is being worked anywhere in the Aegean. Instead, many objects manufactured earlier are now deposited deliberately as heirlooms. For example, the surviving examples of seals are now offered as votives in tombs and shrines; a few come from late contexts in domestic areas. ${ }^{528}$

\section{Trade and Interconnections}

In Crete, Mycenaean pottery continues to be imported, while Chania Workshop pottery is exported to Boeotia, Euboea, the Cyclades, and Cyprus. ${ }^{529}$ Chaniot pottery continues to be found in Italy and at Antigori, Sardinia, while Gray wares and locally made Italian wares have been identified in late lev-

527 D.C. Haggis and M.S. Mook, "The Kavousi Coars€ Wares," AJA 97 (1993) 265-93.

${ }^{528}$ From tombs come, e.g., CMS II.3, nos. 133-36 and 276, and V, Suppl. 1A, no. 50. From the shrine at Karphi comes the Protopalatial seal CMS II.2, no. 199. Domestic contexts: CMS V, Suppl. 1A, nos. 123 and 397; and Nowicki, in Coulson and Tsipopoulou (supra n. 519) pl. XV.6-7.

${ }^{529}$ F. Schachermeyr, "Mykenisch IIIC auf dem griechischen Festland und auf Kreta," 4th CretCong I (1980) 539-43. Chania Workshop pottery: Popham, in Karageorghis (supra n. 477) 178-91, esp. 187; E. Hallager 1988 (supra n. 412) fig. 3, caption.

${ }^{530}$ Kommos III, 165-68. M. Tsipopoulou and L. Vagnetti, "A Late Minoan III Grey Wheel-made Piriform Jar from Eastern Crete," SMEA 34 (1994) 43-50.

${ }^{531}$ Cypriot pottery: J.A. Barlow, D.L. Bolger, and B. Kling eds., Cypriot Ceramics (Philadelphia 1991); Kommos III, 182-83. For special studies, see F. Schachermeyr, "The Pleonastic Pottery Style of Cretan Middle III C and Its Cypriote Re. lations," in Karageorghis (supra n. 206) 204-14; E. Hallager 1988 (supra n. 412) 119; Lambrou-Phillipson (supra n. 310). Canaanite jars: Kommos III, 157-61, 182-83; O. Negbi and M. Negbi, "Stirrup Jars versus Canaanite Jars," in Zerner and Zerner (supra n. 302) 319-29. The only Canaanite ware els at Kommos and Chania. Contemporary Gray wares look like Minyan ware, though dull; they are not very well fired, come in local shapes, and are wheelmade. Similar wares come from Karphi and East Crete. ${ }^{530}$ Cypriot pottery, especially White Slip II milkbowls, is found at several sites - Knossos, Kommos, Zakros, and especially Chania - and Canaanite jars appear at no fewer than 12 sites, produced in both northern and southern Syro-Palestinian and occasionally local Cretan fabrics. ${ }^{531}$

Little Minoan pottery, however, was exported farther eastward, especially east or south of Cyprus. ${ }^{532}$ It is possible, as Banou notes, that the earlier "commercial line that had been established in LM I between several sites of E. Crete (Pseira, Zakros and possibly Gournia and Mochlos) and the E. Mediterranean was no longer a vital vein of commerce." ${ }^{533}$ Texts that date to the reign of Ramses III refer to the 12th-century invasions of the Sea Peoples, ${ }^{534}$ some of whom have been thought to be Minoan, but there is no explicit proof of this.

\section{Religion}

With the disappearance of the Cretan palaces early in IIIB, the exercise of any palatial control over religion vanishes. In the succeeding period, three main types of cult area can be identified: 1) at the borders of ruined centers, where vestiges of structures were still standing (e.g., Kannia, the Shrine of the Double Axes in the east wing at Knossos, the nearby Cara-

from East Crete is a flask and some sherds from Pseira, House AD: Betancourt and Davaras, in Cretan Studies (supra n. 34); Banou (supra n. 34) 185.

532 Two LM IIIB coarse-ware stirrup jars, one of which is inscribed, and a LM IIIC deep bowl come from Athie. nou in Cyprus: T. Dothan, "Minoan Elements and Influ. ence at Athienou, Cyprus," in Karageorghis (supra n. 206) 175 (from stratum III). Hankey (supra n. 493) lists LM IIIB pottery from Amman, Tell Abu Hawam, and Lachish, and coarse-ware stirrup jars from Beirut, Tell Abu Hawam, and Minet el Beida tomb 3, two of which are inscribed with potter's marks. S. Hiller, "Levanto-Helladic Kelche," RDAC 1978, 91-102 cites LM IIIC from Enkomi. Some Cypriot White Slip II is found in LM IIIB levels at Chania (E. Hal lager 1988 [supra n. 412] 119). Kommos III, 162-63 lists a single Egyptian jar in LM IIIB levels at Kommos. None of this material has been scientifically tested.

${ }^{533}$ Banou (supra n. 34) 187. There are no "fine, large decorated kraters" of early IIIB found east or south of Cy. prus (Hankey [supra n. 493] 153) and no foreign pottery, for instance, in the LM IIIA and B levels at Zakros or Pa. laikastro: Banou (supra n. 34) 191, n. 19.

${ }^{534}$ Cline 116-20; T. Dothan, "Tel Miqne-Ekron," in S. Gitin ed., Recent Excavations in Israel (Dubuque 1995) 41-59. 
vanserai Spring Chamber, and presumably at Gazi); 2) local shrines in settlements and individual houses (e.g., Ayia Triada, Prinias, Karphi, Kavousi Vronda); and 3) at peak and cave sanctuaries (e.g., Koumasa) and earlier tholoi, as at Stylos. All these are now evidently under local control. ${ }^{535}$

The changes in cult equipment that began in the Final Palatial period become even more pronounced in the later stages of IIIB and C: MGUAs remain the dominant religious statuette, often occurring in multiple examples associated with snakes, horns of consecration, and the double ax. The MGUA may have replaced, subsumed, or supplemented the deities mentioned in the earlier Linear B texts at Knossos and Chania. At Kavousi Vronda, these figures were made apparently in sets with a backing plaque and a snake tube. The terracotta statues themselves, some approaching $80 \mathrm{~cm}$ in height, come from Gazi, west of Herakleion; Kannia in the Mesara; and Karphi and Kavousi, toward the eastern end of the island. The goddess often wears an elaborate tiara with var. ious combinations of elements: poppy seedpods, horns of consecration, or birds.

The third locus of cult activity, peaks and caves, shows a resurgence and revival after the Final Palatial period, continuing on into the Early Iron Age. The peak sanctuary on Mt. Juktas continued to be used, as well as the open-air sanctuary of Kato Syme. The latter is one of the few places in the Aegean where continuity of cult can be demonstrated between the prehistoric and Archaic periods. After an apparent gap between LM IB and IIIB, the Kophinas peak was reused in IIIC, and a small IIIC settlement was established just outside the sanctuary.

It is surely significant that, in IIIC, Crete and the mainland share several religious features: Mycenaean figurines of the phi type ${ }^{536}$ found around

\footnotetext{
${ }_{535}$ Gesell 61; Kanta; B. Rutkowski, "Tradition und neue Formen in den spätminoischen Heiligtümern," in Thomas (supra n. 390) 13-24; A. Peatfield, "After the 'Big Bang'What?" in S.E. Alcock and R. Osborne eds., Placing the Gods (Cambridge 1994) 19-36; A. Konecny, Gebaute minoische und mykenische Siedlungsheiligtümer der ägäischen Spätbronzezeit III (Diss. Univ. of Vienna 1988). Ayia Triada: F. Carcini and A.L. D'Agata, "Aspetti dell'attività cultuale a Creta nel III e nel II millennio a.C.," in Scienze dell'antichità. Storia archeologia antropologia 3-4 (1989-1990) 238-42; D'Agata, "I santuari sul 'Piazzale dei Sacelli' ad Haghia Triada (Creta)," in Atti (supra n. 429). Prinias: G. Rizza, "Nuove scoperte a Priniás," 3rd CretCong (1973) 286-89; Rizza, "Ceramiche figurate da Priniás," AntCr 2 (1974) 153-60; Rizza (supra n. 511). Karphi: B. Rutkowski, “The Temple at Karphi,” SMEA
}

hearths and doorways as at Chania, and the small community bench shrine with terracotta female figurines. But the differences are equally important. The mainland assemblages do not include the snake tubes and backing plaques found on Crete, and the terracotta cylindrical model seems purely Cretan. While the figurines in both locations lift their arms, only the Cretan ones have detailed renderings of the thumbs, and only the Cretan figures wear elaborate tiaras, in contrast to the simple poloi of the mainland figures. The headgear suggests that these are divine, not human, figures, but it is not clear whether they represent different goddesses or aspects of a single goddess. ${ }^{537}$

Recent experiments with re-creating some of the Kavousi figurines demonstrate that each large terracotta statuette is built of two pot shapes, a jug for the body and a smaller, inverted jug for the head, with facial features, breasts, and arms modeled separately. These figures took at least a day, and probably several, to make. Their technique strongly sug. gests that they were made not by sculptors but rather by local potters, who used the same fabrics in mak. ing local cooking pots and pithoi (the two fabrics required different firing temperatures); perhaps the cult equipment was ordered in sets by individuals or families. ${ }^{538}$

\section{END OF THE BRONZE AGE IN CRETE}

The transition from the Late Bronze Age in Crete to Cretan Protogeometric seems to have been effected relatively peacefully: sites continue or are abandoned without major destructions. ${ }^{539}$ Often termed Subminoan, material from this period, roughly 11001000/975 B.C., comes mainly from Karphi, Kavousi Vronda, and Vrokastro. Some Subminoan material

26 (1987) 257-65. Kavousi: G. Gesell, "The Goddess with Up-raised Hands from Kavousi, Ierapetras," in Atti VII Congresso internazionale di studi cretesi, Rethymnon 1991 (in press). Stylos Apokoronou: C. Davaras, AAA 4 (1971) 42-44.

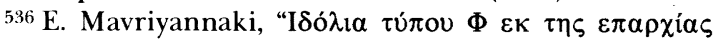

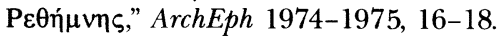

${ }^{537}$ J.N. Coldstream, Deities in Aegean Art before and after the Dark Age (Bedford College Inaugural Lectures, London 1977); G.C. Gesell, AJA 100 (1996) 404 (abstract).

${ }^{538}$ G.C. Gesell and T.C. Saupe, "Methods Used in the Construction of Ceramic Objects from the Shrine of the Goddess with Up-raised Hands at Kavousi," in Techne 123-26.

${ }^{539}$ For two general studies: F. Schachermeyr, Kreta zur Zeit der Wanderungen (Vienna 1979); and D.G. Gondicas, Re cherches sur la Crète occidentale (Las Palmas 1987). 
is known from Knossos, especially the Spring Chamber and from the nearby cemeteries at Zapher Papoura, Ayios Ioannes, and Fortetsa. ${ }^{540}$ Several features characterize the transition to the Early Iron Age: the slow appearance of iron for tools and weapons, the increasing frequency of cremation burials and small tholos tombs from early in LM IIIC on, including the reuse of tombs, and the eventual disappearance of MGUAs. ${ }^{541}$

Among the many survivals and revivals, some social customs may have been retained, including aspects of law, land tenure, herding, and possibly rites of male passage. ${ }^{542}$ Two examples of continuity are impressive: pictorial vase painting ${ }^{543}$ and the inscriptions from East Crete using Greek letters to write "Eteo-Cretan."

\section{DIRECTIONS FOR FURTHER WORK}

It should be clear from this survey that the archaeology of Late Bronze Age Crete has changed enormously since its inception just over a century ago. Excavation has far outpaced publication, and a major priority for at least the next decade should be the publication of sites and material. The concentration on excavating elite architecture needs to be balanced with a more comprehensive presentation of domestic and nonelite architecture, especially for the Final and Postpalatial periods where much

${ }^{540}$ J.N. Coldstream, "Knossos: An Urban Nucleus in the Dark Age?" in Musti et al. (supra n. 363) 287-99, esp. 290; AR 25 (1979) 46, figs. 8-11; Sackett (supra n. 512) 60-65; J.K. Brock, Fortetsa (Cambridge 1957).

${ }^{541}$ R. Maddin, J.D. Muhly, and T.S. Wheeler, "How the Iron Age Began," Scientific American 237:4 (1977) 122-31; S. Sherratt, "Commerce, Iron, and Ideology," in Karageorghis (supra n. 511) 88-91; A.M. Snodgrass, "The Coming of Iron in Greece," in M.L.S. Sorensen and R. Thomas eds., The Bronze Age-Iron Age Transition in Europe (Oxford 1989) 22-35; and J.C. Waldbaum, "Copper, Iron, Tin, Wood," Ar. chaeomaterials 3 (1989) 111-22.-Early iron from Crete: Vrokastro (late LM IIIC: Coulson and Tsipopoulou [supra n. 519] 84), Karphi (LM IIIC: Watrous [supra n. 515] 325, tools), Katsamba house, phase II (LM IIIC: Kanta 27, a piece), Mouliana Tholos B (LM IIIC: Kanta 176, a piece).

The earliest cremation burials date to LM IIIA2, in the Olous cemetery (Kanta 129; cf. the possible cremation burial in Kalyvia tomb 8, LM IIIA1-2; Kanta 99). Also see C. Davaras, "Cremations in Minoan and Sub-Minoan Crete," AntCr 1 (1973) 158-67. For Early Iron Age tombs, see M.

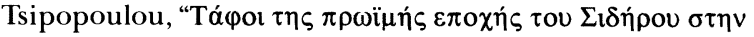

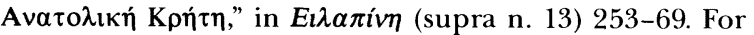
reuse of tombs, see H. Catling, "Heroes Returned? Subminoan Burials from Crete," in J.B. Carter and S.P. Morris eds., The Ages of Homer (Austin 1995) 123-36; Kanta (supra of our evidence has come from funerary contexts. For all periods, future excavation should be directed toward establishing the actual limits of a settlement; the precise size of most sites is unknown.

A few specific concerns follow. Jewelry must be analyzed in terms of typology, context, technique, and representations before it can be incorporated into analyses of Minoan society and be appreciated as a social artifact. Important advances are taking place in the study of Minoan pottery, particularly for the Final and Postpalatial periods, but for all periods the study of pottery needs to be integrated more thoroughly with analyses of architectural and demographic change. The groundwork for the study of Minoan seals and sealings has been laid, but nonspecialist scholars generally have not made use of these artifacts as yet. A new book on Minoan architecture is needed, integrating the architectural evidence-materials, techniques, and the buildings themselves - with theoretical models for building a cognitive plan of Minoan space. Despite several surveys of Minoan larnakes, the painted larnakes are today largely unstudied; a comprehensive catalogue of these could greatly increase our understanding of Late Minoan society.

Finally, life on Crete has been revolutionized, for better or for worse, in just the last three generations. Not only will the archaeological heritage of Crete

n. 363). MGUAs: R. Hägg, "Sacred Horns and Naiskoi," in V. Karageorghis ed., Proceedings of an International Symposi. um: "The Civilizations of the Aegean and Their Diffusion in Cy. prus and the Eastern Mediterranean, 2000-600 B.C." (Nicosia 1991) 79-83.

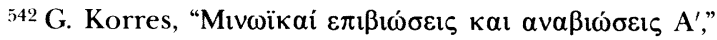
3rd CretCong (1973) 411-76. L. Foxhall, "Bronze to Iron," BSA 90 (1995) 239-50; J. Whitley, "Social Diversity in Dark Age Crete," BSA 86 (1991) 341-65; R.F. Willetts, "Cretan Law and Early Greek Society," AntCr 2 (1974) 22-31; Willetts, "Neoi and neotas," 4th CretCong I (1980) 643-53; Willetts, "Economy and Society," Cretan Studies 1 (1988) 257-68; and Willetts, "Aspects of Land Tenure in Dorian Crete," in Musti et al. (supra n. 363) 209-14. Koehl (supra

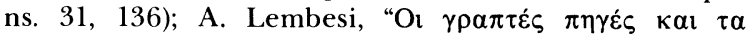

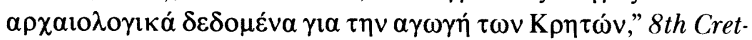
Cong (forthcoming).

${ }^{543}$ J.N. Coldstream, "Sphinxes and Griffins from Geometric Crete," AntCr 2 (1974) 161-64; Coldstream, "The Meaning of the Regional Styles in the Eighth Century B.C.," in R. Hägg ed., The Greek Renaissance of the Eighth Century B.C. (Stockholm 1983) 17-25; N.B. Reed, "Griffins in PostMinoan Cretan Art," Hesperia 45 (1976) 365-79; and L. Rocchetti, "La necropoli di Curtes," 5th CretCong A2 (1990) 261-65. 
need vigorous, concerted efforts and judicious choices to preserve it, but, as Blitzer has passionately pointed out to us, within just a few years, direct, personal experience of the self-sufficient life will become a memory to all but the oldest inhabitants of the island. Careful efforts must be made now not only to record it but also to retrieve it through academic studies of daily living: animal and plant husbandry, pharmacopiae, customs, and traditions. Much attention has been devoted in recent decades to major theoretical constructs of politics, state theory, and the state of the profession. One of the consequences is that the lived life of individuals has all but been neglected. ${ }^{544}$ We should want to know more about the Minoans themselves, for if ever there was a goal of archaeology, it is the study of people, especially at the commonest level.

DEPARTMENT OF CLASSICAL STUDIES

DUKE UNIVERSITY

P.O. BOX 90103

DURHAM, NORTH CAROLINA 27708-010 3

PREHAK@ACPUB.DUKE.EDU

JYOUNGER@ACPUB.DUKE.EDU
544 A major theme of the Eighth Cretological Congress, 10-13 September 1996, concerned the domestic aspects of Cretan archaeology. 